Historic, Archive Document

Do not assume content reflects current scientific knowledge, policies, or practices. 

a. SD $/ 1$

- 448

\section{Frofselcinc: \\ end shrubland \\ holojtort types \\ of Western Monteind}

W. F. Mueggler dnd W. L. Stewart

USDA Forest Service General Technical Report INT-66

INTERMOUNTAIN FOREST AND RANGE EXPERIMENT STATION

Forest Service, U.S. Department of Agriculture

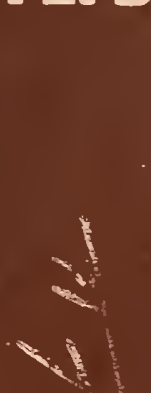

$>$ 
USDA, Mationai Agricultural Library H.t.

1020 Estmoro Blvd

Eotsvile, MD 20705-2351 


\title{
Grassland and shrubland habitat types of Western Montana
}

\author{
W. F. Mueggler and W. L. Stewart
}




\section{THE AUTHORS}

WALTER F. MUEGGLER, Principal Plant Ecologist for the Intermountain Station, spent 13 years conducting research on western Montana mountain rangelands. He is currently Leader of the Aspen-Mountain Grassland Ecology Research Work Unit at Logan, Utah. He obtained his B.S. degree from the University of Idaho, M.S. degree from the University of Wisconsin, and Ph.D. degree in Plant Ecology from Duke University.

WILLIAM L. STEWART, now Regional Pesticide Specialist, USDA Forest Service, Northern Region, spent 3 years as a Range Conservationist in southwestern Montana. For two of those years he assisted in the development of the classification of and management implications for western Montana grasslands and shrublands. He obtained his B.S. and M.S. degree from Washington State University, and currently is working on a Ph.D degree at Washington State University. 


\section{ACKNOWLEDGMENT}

Major support for this study was provided by the Northern Region of the Forest Service, U. S. Department of Agriculture, through a cooperative agreement with the Intermountain Forest and Range Experiment station.

W. P. Handl, formerly Range Scientist with the Intermountain Station, participated in collecting field data, adapting computer programs, analyzing data, and developing the classification. Drs. G. A. Nielsen and L. C. Munn, Montana State University, supplied soil analyses. Research assistants participating in field sampling included Rick Miller, Rick Young, Mike McGinnis, Bob Yeager, and Wayne Leininger. 
A classification system is presented for the grasslands and shrublands of the mountainous western third of Montana. The classification utilizes the habitat type concept and is based upon potential natural vegetation. Data on plant species and environment from 580 relatively undisturbed stands were analyzed to form the classification. Twenty-nine habitat types occurring in 13 climax series are defined and described. A diagnostic key utilizing indicator plant species is provided for field identification of the habitat types.

Vegetation composition, distribution, and environment of each habitat type are described in the text. Tables are provided for detailed comparisons. Management related information on forage productivity, composition changes with grazing, and range management practices is summarized for each type. 


\section{CONTENTS}

Page

INTRODUCTION . . . . . . . . . . . . . . . . I

CONSIDERATIONS . . . . . . . . . . . . . . . . 2

KEY TO HABItAT TYPES . . . . . . . . . . . . . . . 5

TYPE DESCRIPTIONS AND MANAGEMENT IMPLICATIONS . . . . . . 10

Stipa comata/Bouteloua gracilis h.t. . . . . . . . 10

Agropyron spicatum/Bouteloua gracilis h.t. . . . . . 14

Agropyron spicatum/Agropyron smithii h.t. . . . . . . 18

Agropyron spicatum/Poa sandbergii (MONT) h.t. . . . . 21

Festuca scabrella/Agropyron spicatum h.t. . . . . . 23

Festuca scabrella/Festuca idahoensis h.t. . . . . . 27

Festuca idahoensis/Agropyron smithii h.t. . . . . . 30

Festuca idahoensis/Agropyron spicatum h.t. . . . . . 32

Festuca idahoensis/Agropyron caninum h.t. . . . . . 38

Festuca idahoensis/Carex filifolia h.t. . . . . . . 41

Festuca idahoensis/Stipa richardsonii h.t. . . . . . . 42

Festuca idahoensis/Deschampsia caespitosa h.t. . . . . 44

Deschampsia caespitosa/Carex spp. h.t. . . . . . 45

Artemisia arbuscula/Agropyron spicatum h.t. . . . . 47

Artemisia arbuscula/Festuca idahoensis h.t. . . . . 49

Artemisia tridentata/Agropyron spicatum (MONT) h.t. . . 50

Artemisia tridentata/Festuca scabrella h.t. . . . . 54

Artemisia tridentata/Festuca idahoensis (MONT) h.t. . . 55

Artemisia tripartita/Festuca idahoensis (MONT) h.t. . . 58

Potentilla fruticosa/Festuca scabrella h.t. . . . . 60

Potentilla fruticosa/Festuca idahoensis h.t. . . . . 62

Purshia tridentata/Agropyron spicatum (MONT) h.t. . . . 64

Purshia tridentata/Festuca scabrella h.t. . . . . . 66

Purshia tridentata/Festuca idahoensis (MONT) h.t. . . . 67

Cercocarpus ledifolius/Agropyron spicatum h.t. . . . 69

Rhus trilobata/Agropyron spicatum h.t. . . . . . 71

Rhus trilobata/Festuca idahoensis h.t. . . . . . . 72

Sarcobatus vermiculatus/Agropyron smithii h.t. . . . 73

Sarcobatus vermiculatus/Elymus cinereus h.t. . . . . 74

OTHER VEGETATION TYPES .................. 75

PUBLICATIONS CITED . . . . . . . . . . . . . 77

APPENDIX A--METHODS. . . . . . . . . . . . 85

APPENDIX B--WESTERN MONTANA ENVIRONMENT. . . . . . . . 91

Topography and Geology. . . . . . . . . . . . 93

Soils... . . . . . . . . . . . . . . . 94

Climate.................. . 94

APPENDIX C--ENVIORNMENT PARAMETERS FOR IMPORTANT HABITAT

TYPES. . . . . . . . . . . . . . . . . 97

Cl.--General. . . . . . . . . . . . 99 
C2.--Soil Physical Properties . . . . . . . . 100

C3.--Soil Chemical Properties.......... 102

APPENDIX D--COVER CLASS SUMMARIES BY HABITAT TYPES . . . . 103

APPENDIX E--SPECIES CONSTANCY AND CANOPY COVER BY HABITAT

TYPE ...................... 107

El.--Stipa comata Series. . . . . . . . . . 109

E2.--Agropyron spicatum Series........... 110

E3.--Festuca scabrella Series........... 113

E4.--Festuca idahoensis Series. . . . . . . . . 116

E5.--Deschampsia caespitosa Series. . . . . . . . 120

E6.--Artemisia arbuscula series . . . . . . . . 121

E7.--Artemisia tridentata series. . . . . . . . . 123

E8.--Artemisia tripartita Series. . . . . . . . 126

E9.--Potentilla fruticosa Series. . . . . . . . . 127

El0.-Purshia tridentata Series. . . . . . . . . 130

Ell.-Cercocarpus ledifolius Series. . . . . . . . 132

El2.-Rhus trilobata Series. . . . . . . . . . . 133

El3.-Sarcobatus vermiculatus Series... . . . . 135

APPENDIX F--PALATABILITY RATINGS . . . . . . . . . 137

APPENDIX G--COMPARISONS OF DIFFERENTIALLY-GRAZED PAIRED

STANDS ..................... 141

Gl.--Stipa comata Series. . . . . . . . . 143

G2.--Agropyron spicatum Series. . . . . . . . 144

G3.--Festuca scabrella/Agropyron spicatum h.t. . . . 146

G4.--Festuca scabrella/Festuca idahoensis h.t. . . . 148

G5.--Festuca idahoensis series. . . . . . . . 150

G6.--General Description of Paired Stands . . . . . 152 


\section{INTRODUCTION}

The highly varied environment of the Northern Rocky Mountains creates a mosaic of forest, shrubland, and grassland vegetation. Species composition and productivity, and the consequent potential values, differ greatly between and within these major vegetation types. The ability to identify land units and relate them to both their inherent capability to produce various resources and their response to management activities is essential for multiple use planning and intensive resource management on our western wildlands.

The need to classify vegetation types and land units has long been recognized by natural resource managers. It is reflected by the development and use of numerous forest and range type classifications during the past fifty years. Unfortunately, such classifications have tended to stress current site occupancy and identity by a few commercially important plants. Little consideration has been given to the successional status of the existing vegetation or to the potential productivity of the environment as reflected by the "climax" vegetation.

In the past decade, the habitat type concept of environmental classification developed by Daubenmire (1952) has gained increasing acceptance in the West, particularly by forest managers. This concept stresses use of the entire climax plant community as an environmental integrator, thus permitting identification of environments (habitats) with similar biotic potentials. All environments with the potential to support approximately the same kind of stable (climax) mix of plant species are considered to be within the same habitat type regardless of current successional status. This approach to classification has been used successfully to classify both forest vegetation (Daubenmire and Daubenmire 1968; Pfister and others 1977) and grassland-shrubland vegetation (Daubenmire 1970) in the Northwest. This type of classification provides the framework essential for organizing information on resource potentials, limitations, and responses to management activities. Forests and rangelands of Montana, Idaho, and Washington are being mapped into site potential units (habitat types) so that information on each habitat type can be more widely applied.

Development of habitat type classifications for nonforested wildland has progressed more slowly than that for forested land. The need to develop such a classification for the nonforested lands of western Montana prompted a cooperative study between, the Forest Service's Northern Region and Intermountain Forest and Range Experiment Station. The results of that study are reported here. The purpose of this study was three-fold: (1) to develop a habitat type classification scheme for the grasslands and shrublands of the mountainous western third of Montana (fig. 1); (2) to describe as well as is currently possible those characteristics of each habitat type that would be useful to the resource manager for developing management practices; and (3) to provide a framework for further management-oriented research.

Meeting the first objective required extensive sampling of relatively undisturbed grasslands and shrublands throughout western Montana and developing a classification based on similarities of the vegetation. The second objective was met by a combination of companion studies on vegetation productivity and soils, and by a synthesis of information found in a thorough review of publications and reports. This information was then related to the habitat types identified. The resulting classification identifies the basic land units to which future research can be tied, thus fulfilling the third objective. 


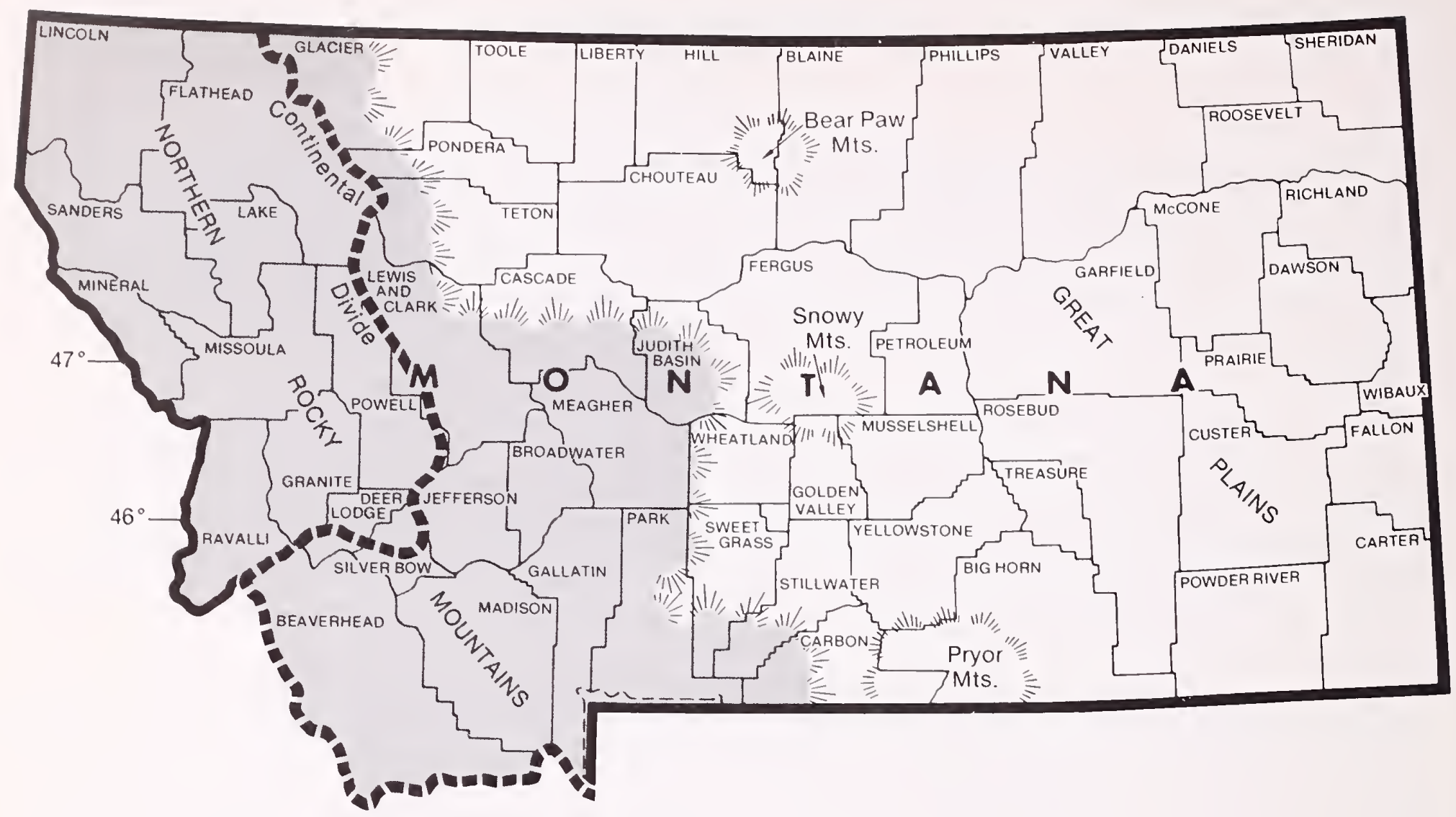

Figure 1.--Physiographic division of lontana showing those portions of Northern Rocky Mountains pertinent to the study.

The nonforested 1 and of western Montana was divided into 29 habitat types, which can be grouped into 13 climax series (table 1). This paper includes a key for identifying the types and a general description of each type. Supplemental information and technical data are given in the appendixes.

\section{CONSIDERATIONS}

The user of this guide to habitat types must bear in mind six considerations created by limitations in the study:

1. As discussed in the methods section (appendix A), development of a habitattype classification should be based on data from a large number of areas of pristine vegetation. These conditions could only be partly met. Known areas of pristine vegetation were few, thus requiring inclusion of communities of varied and poorly documented grazing history. Grazing probably increases the variation in composition between stands which otherwise would be similar; this also increases the uncertainty of breaking out probable habitat types. Therefore, this classification is subject to changes as more information becomes available, especially for habitat types identified on the basis of relatively few stands.

2. Some of the western Montana habitat types are similar to those described by Daubenmire (1970) for the steppe region of eastern Washington. This similarity is somewhat superficial, for it is created primarily by the same dominant and codominant 
species which are the basis for the habitat-type names. Comparison of all species suggests that the Montana types are distinct from those in Washington. A number of our species are associated with the Northern Great Plains flora which does not penetrate into eastern Washington. In like fashion, not all of the secondary species listed by Daubenmire occur in western Montana. Where duplication of our habitat-type names and those used by Daubenmire was unavoidable, a suffix of (Mont.) was added to the name to identify our habitat type as belonging to the Montana classification. This occurred once in the grassland series and five times in the shrubland series.

3. Certain species were taxonomically difficult to separate under the varied developmental stages encountered in the field. Among these were certain species of Lupinus, Astragalus, the more infrequent Poa spp. and certain rhizomatous Agropyron spp. The questionable taxonomic separation of Festuca idahoensis and Festuca ovina necessitated treating this complex as a single species, Festuca idahoensis. We are confident that most of our encounters were with Eestuca idahoensis, but undoubtedly Festuca ovina was sometimes intermixed, particularly on subalpine sites. The possibly unfamiliar Agrypyron caninum species is used by Hitchcock and others (1955-69) for a group including the more familiar, but taxonomically uncertain, Agropyron trachycaulum and Agropyron subsecundum. We have adopted Hitchcock's usage to simplify field identification. Many of the early-drying ephemerals such as Claytonia, Ranunculus, Dodecatheon, and Delphinum bicolor are conspiciously absent from the species lists for the habitat types. These species were usually missed because most of our sampling occurred at midseason after they had dried and disintegrated.

4. In our attempts to identify changes in species composition that were attributable to grazing, we found that lack of consistency in species response was common. Certain species such as Agropyron spicatum and Festuca scabrella responded fairly consistently to grazing, but most species did not. The lack of consistency is probably attributable to a combination of such factors as the class and intensity of livestock use, the relative amount of the species available for grazing, and the stage of vegetation deterioration. We were unable to evaluate these factors separately. We placed a species into the response category of "decreaser" if most of the time it appeared to decline with grazing, and into the "increaser" category if it generally appeared to increase with grazing. Only exotic species that invaded and increased with abusive grazing or other disturbances were classified as "invaders." Many species were not classified because neither our data nor pertinent literature contained reasonably sound evidence of their response.

5. Several sources of error in interpreting impressions gained from visual comparisons of grazed and nongrazed areas and from actual data on canopy cover should be noted. Low mat-forming species, such as Phlox hoodii, may appear to increase substantially with grazing simply because they no longer are hidden by taller vegetation; canopy cover comparisons, however, often show no difference in actual amounts. On the other hand measuring canopy cover before and after grazing on the same area may show a decrease in a palatable species, which may not be real if the species is not adversely affected by partial removal of its canopy at the time of grazing. This possibility should be considered when comparing grazed area with adjacent exclosures. One must also remember that some species of relatively mediocre palatability may initially increase under abusive grazing only to decrease later when such abuse continues to the point where the more palatable plants no longer provide adequate forage.

6. The habitat types described in this report (table 1) and the key for their identification are specific to the mountainous western portion of Montana. The plains areas of the central and eastern part of the state were not included in our sampling. Applicability to adjoining mountainous areas in Wyoming, Idaho, and Canada has not been determined. The key in particular should be used with caution outside of the designated area. The key covers natural grassland and shrubland vegetation within the lower intermontane valleys and foothills on up through the subalpine type. The true alpine areas are not covered by this description. 


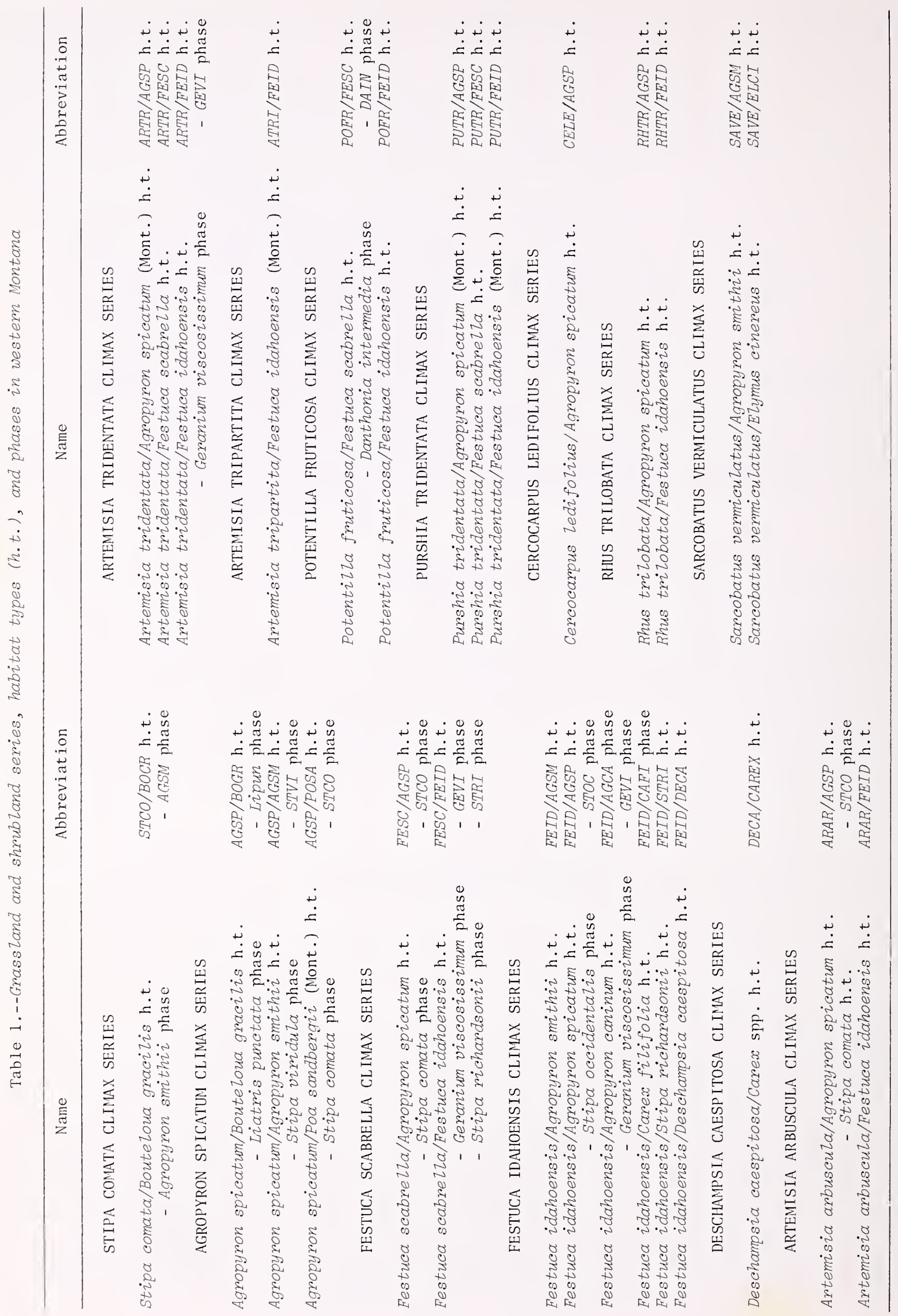



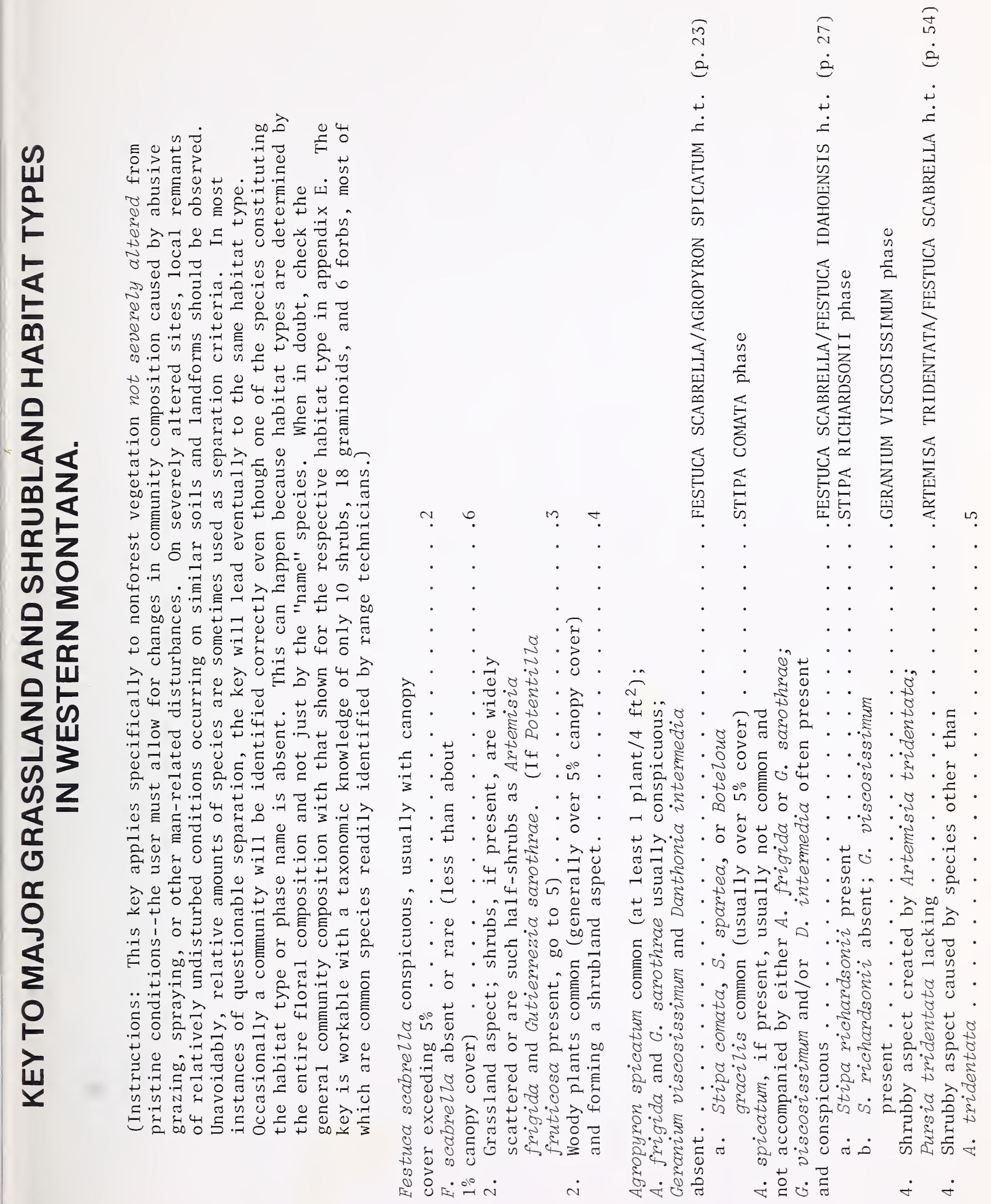


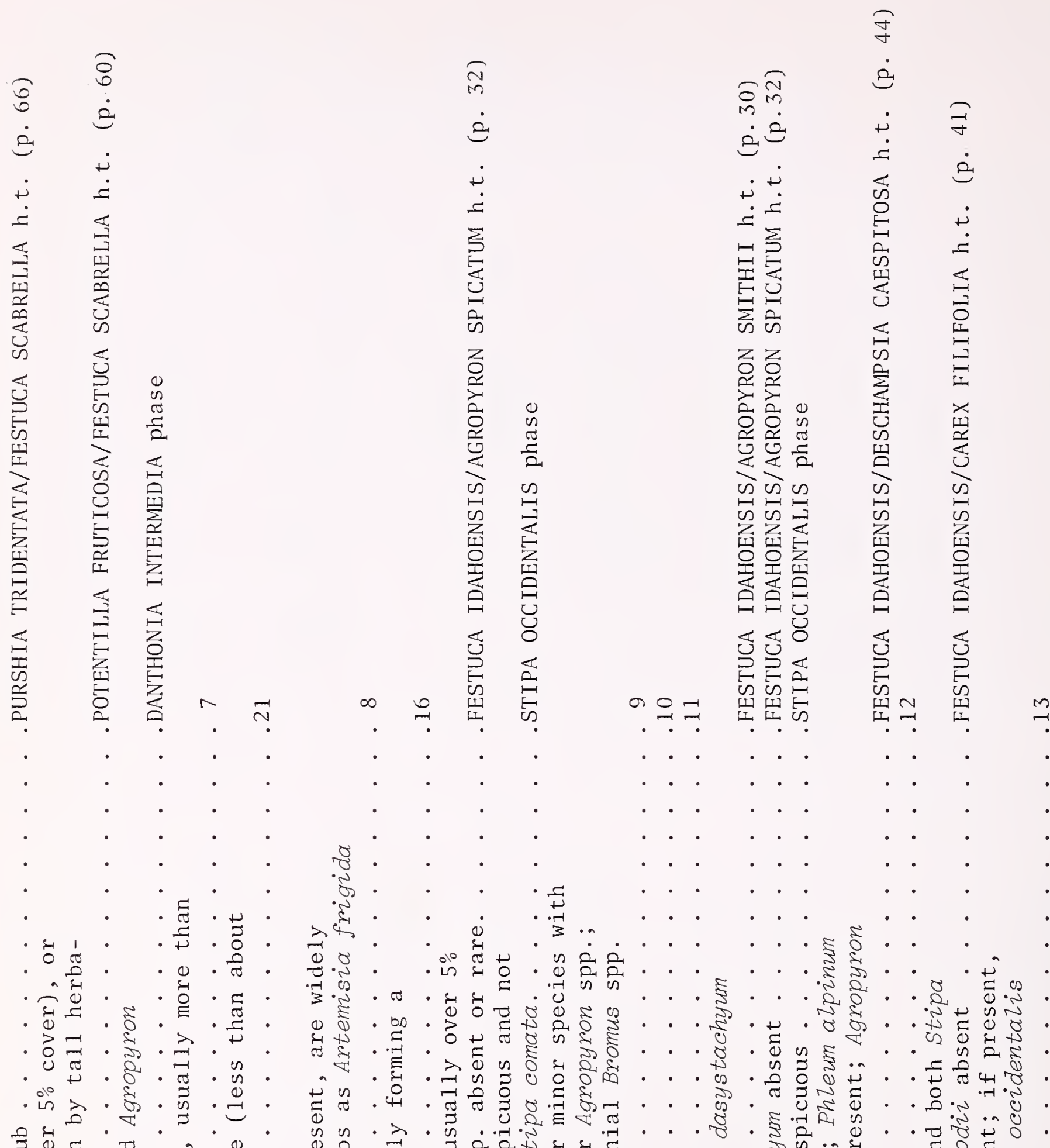

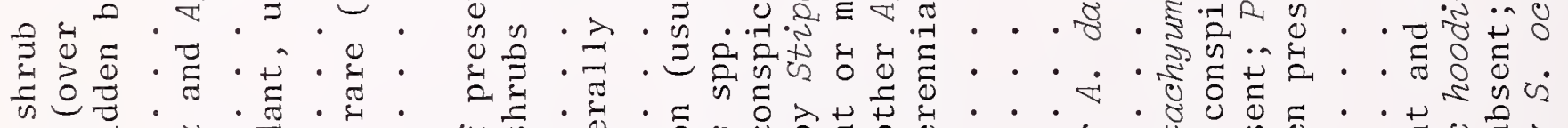

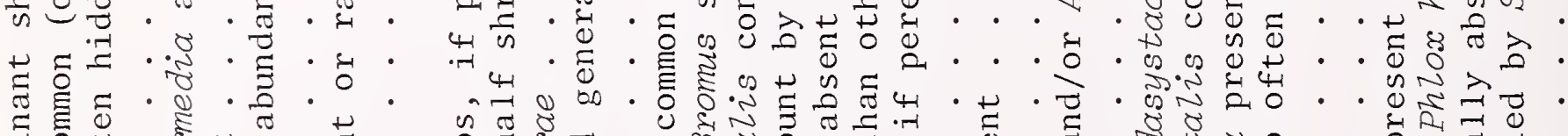

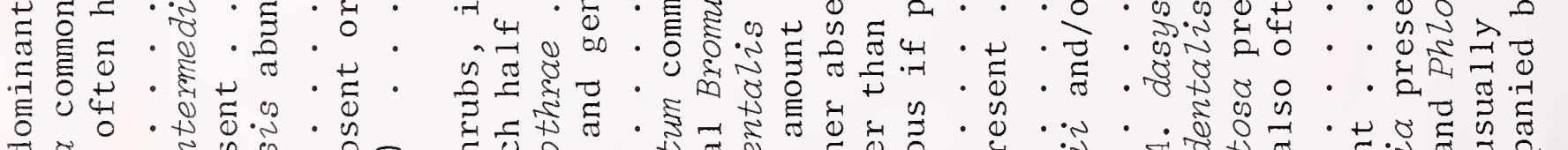

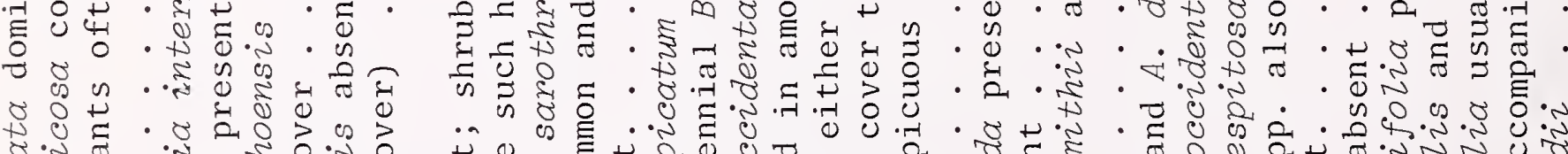
0.4
0.450
0

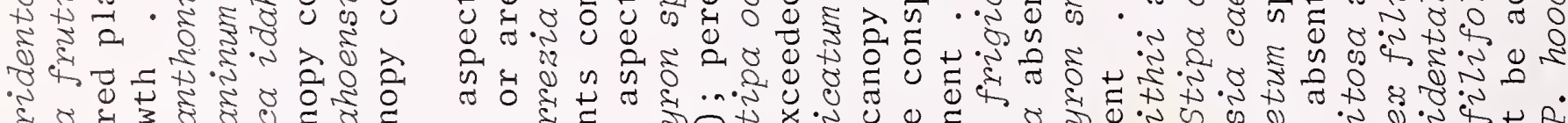

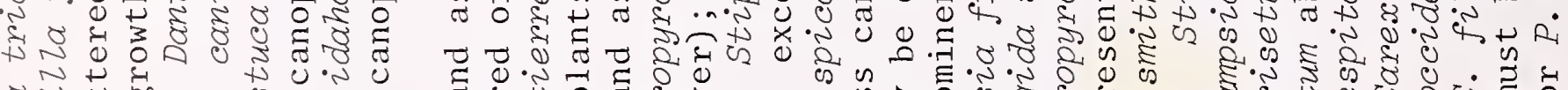
०.

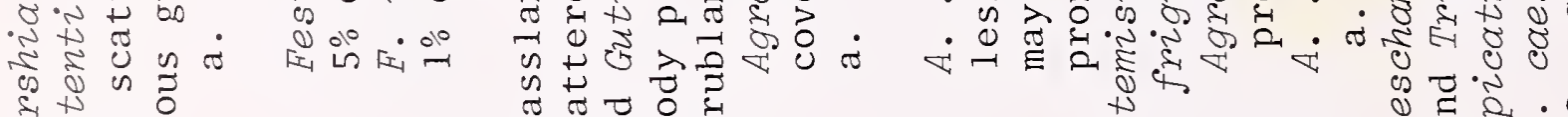

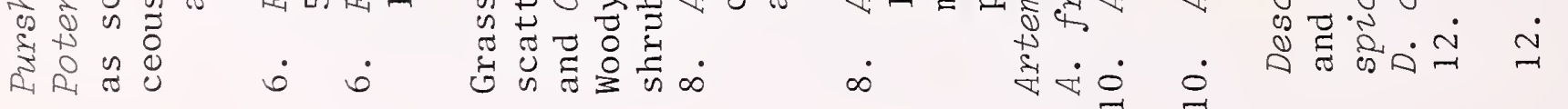
เ่ $\therefore \quad r$ $\dot{\sigma i} \quad \dot{\approx} \quad \dot{二}$ 


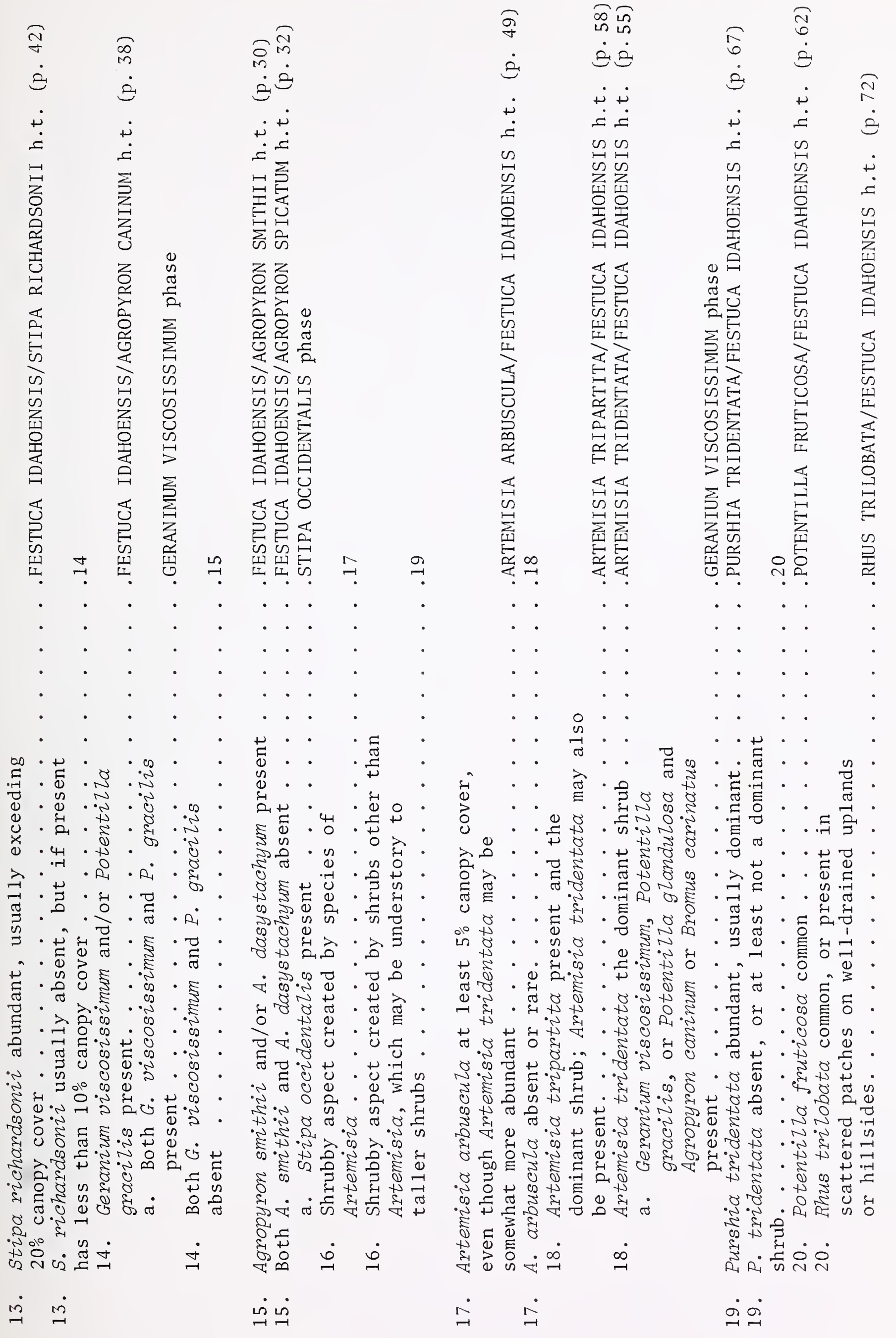




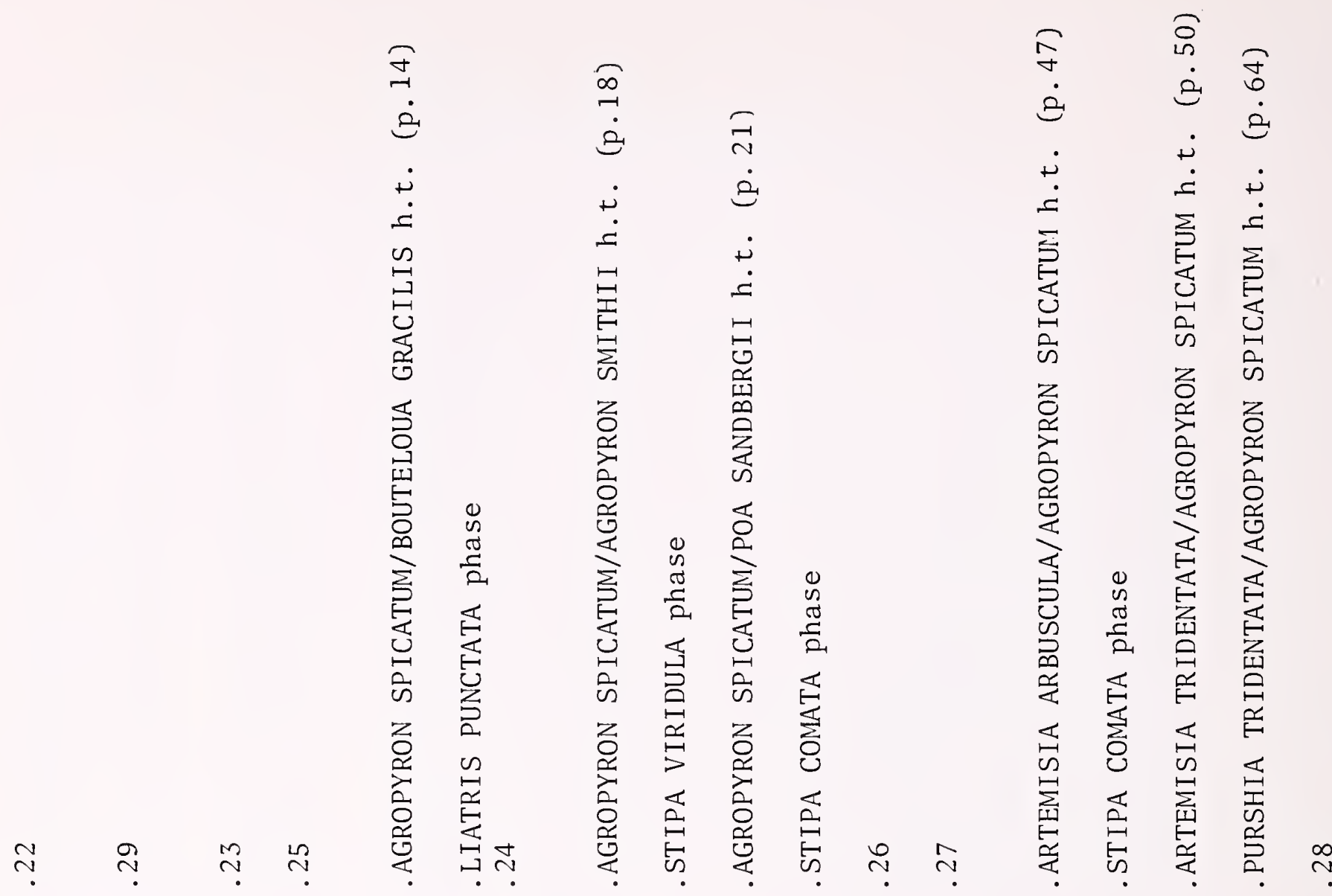

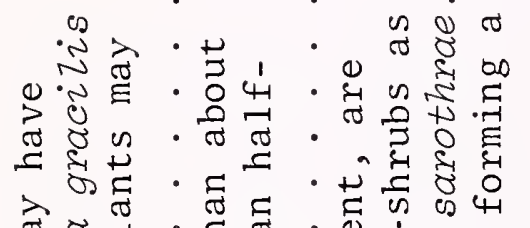

बे

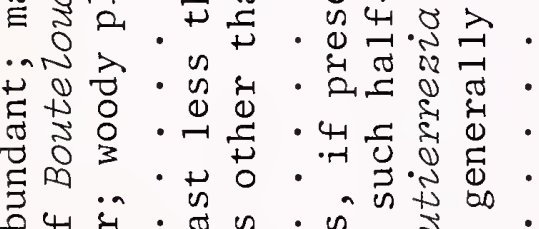

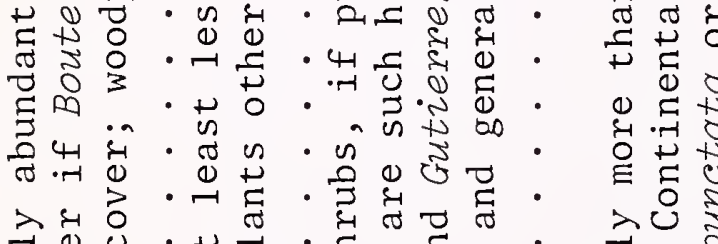

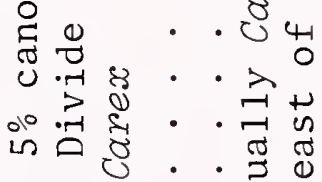

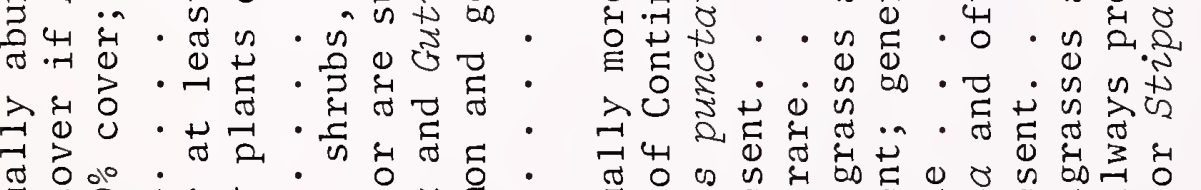

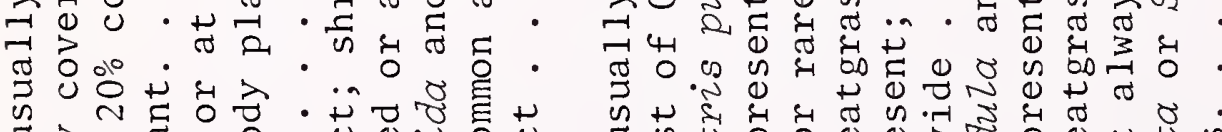

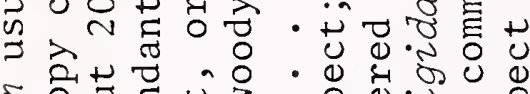
इ

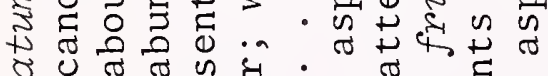
ठ ए त

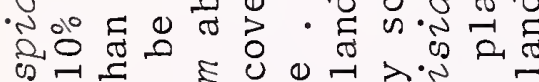
क्न मे

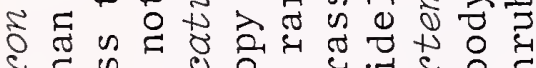

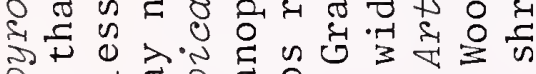

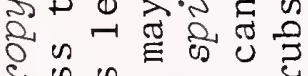

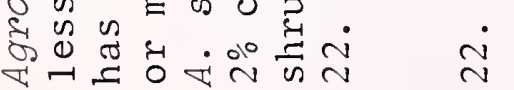

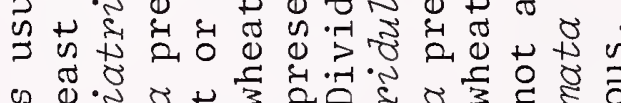

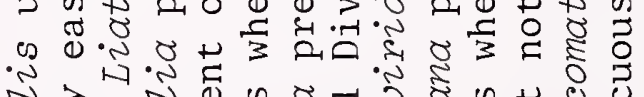

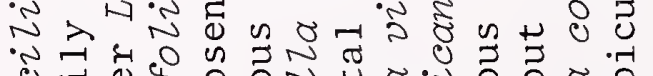

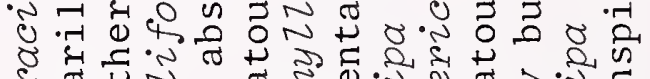
क्ष ơ 每. 可 $\begin{gathered}0 \\ 0\end{gathered}$

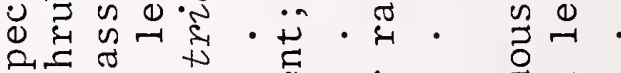
कि का

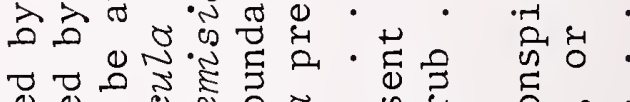

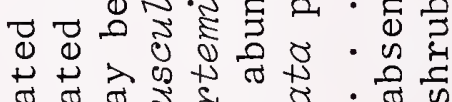

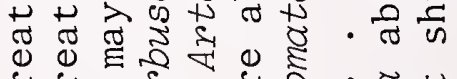

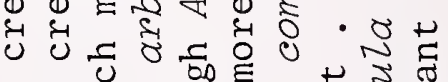

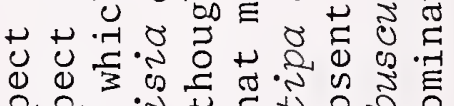

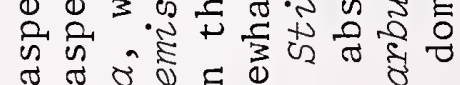

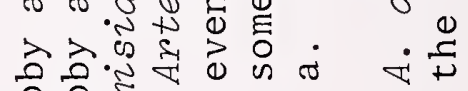
कृ कूष

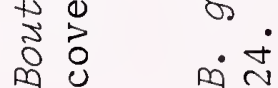
$\dot{n} \quad \dot{m}$ $\dot{\sim}$
क岁的娄定

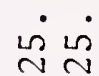

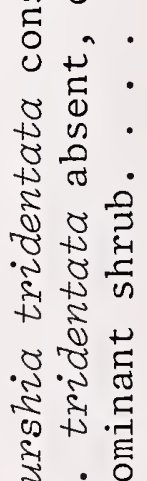

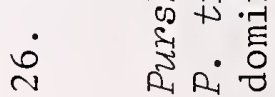

$\dot{\vec{\lambda}} \quad \dot{\pi}$ 


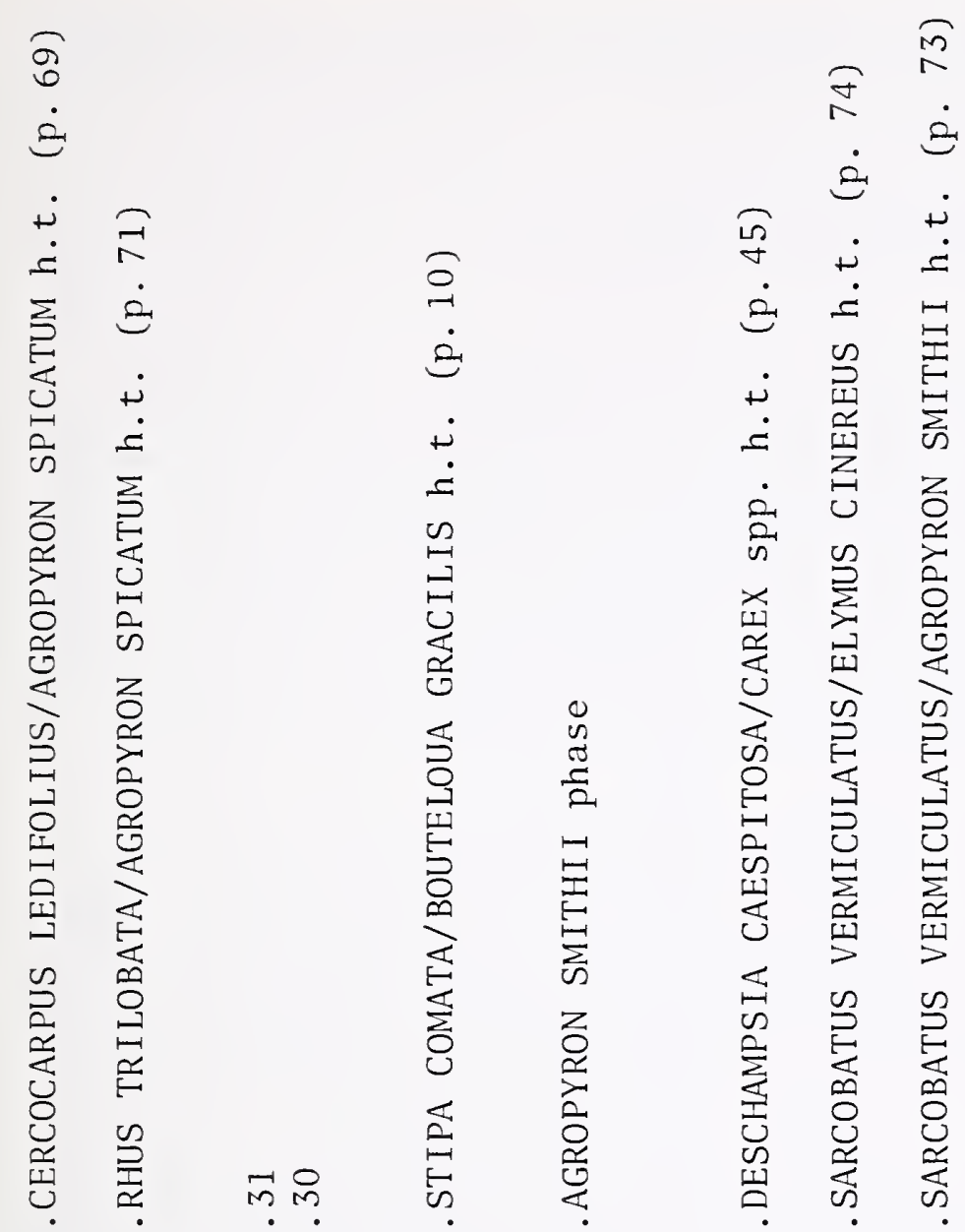

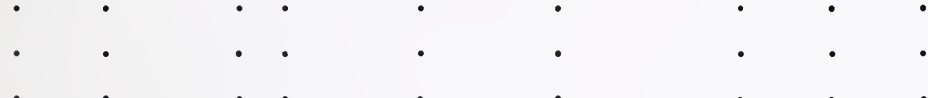

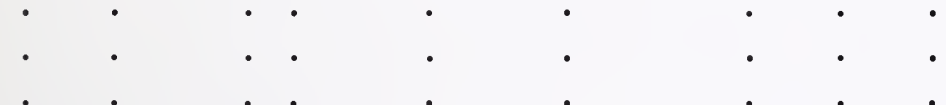

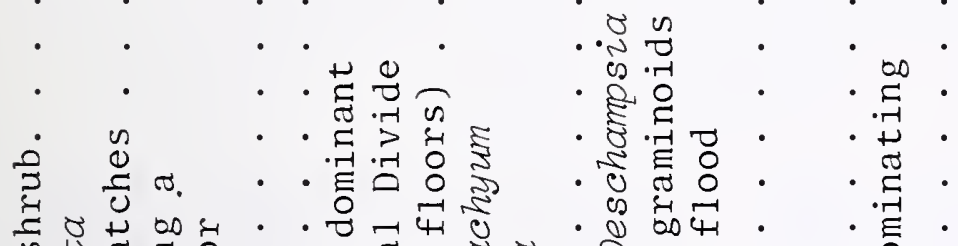

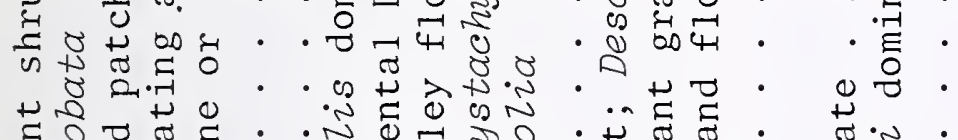

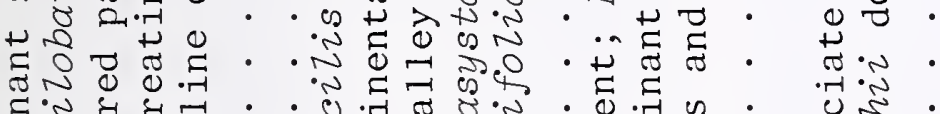

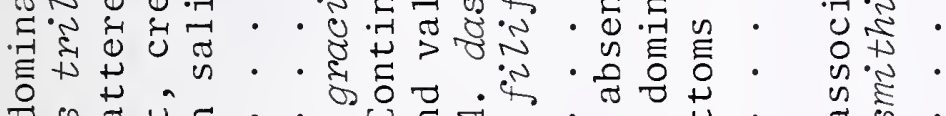

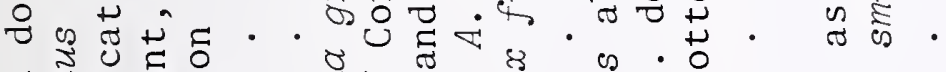

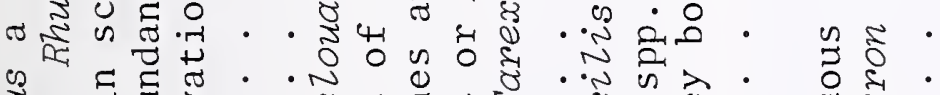

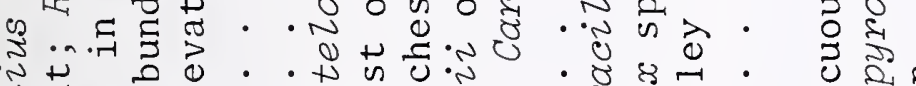

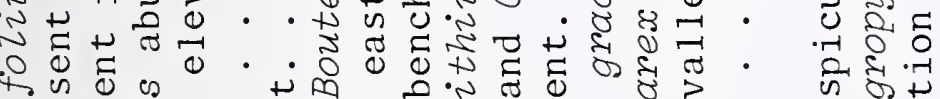

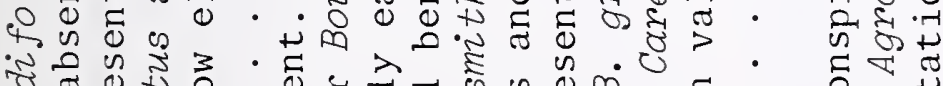

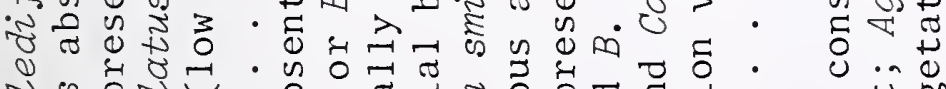

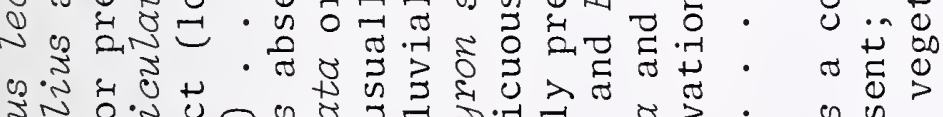

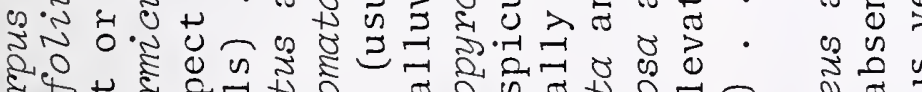

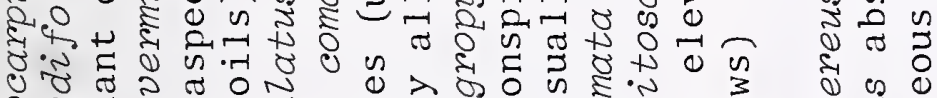
ช d

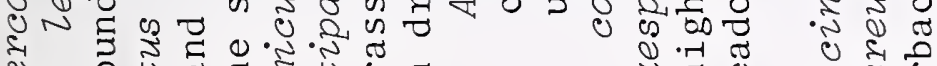

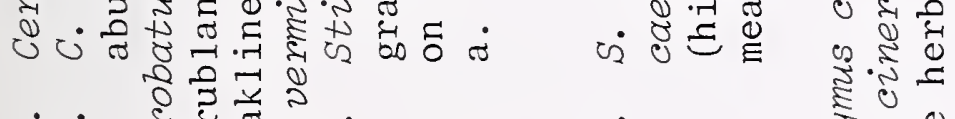

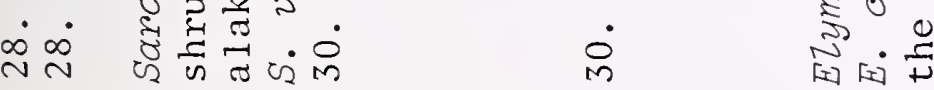
iे $\dot{2}$
लिं 


\title{
TYPE DESCRIPTIONS AND MANAGEMENT IMPLICATIONS
}

\section{Stipa comata /Bouteloua gracilis h.t.}

\author{
$(S T C O / B O G R$ h.t. $)$
}

Distribution and environment.--The STCO/BOGR h.t. occurs primarily in the intermontane valleys east of the Continental Divide and south of $47^{\circ}$ latitude. Usually it is confined to the broad alluvial benches, valley floors, or gently sloping alluvial fans extending into the valleys. Elevations of these sites are generally below 5,000 ft $(1,500 \mathrm{~m})$, but the type has been found as high as $6,100 \mathrm{ft}(1,860 \mathrm{~m})$ in the higher valleys of the extreme southwestern part of the State. This is the driest grassland habitat type in western Montana. Estimated precipitation is between 8 and 14 in $(20$ to $35 \mathrm{~cm})$.

Soils from typical examples of the STCO/BOGR h.t. are of the fine-loamy Borollic Calciorthid subgroup, and are of aridic moisture and frigid temperature regimens (Munn, and others 1978). The solum is mildly alkaline with free calcium carbonate at or near the soil surface (appendix C3). The solum is approximately 20 in $(50 \mathrm{~cm})$ thick, with a 3 to 6 in $(8$ to $16 \mathrm{~cm}$ ) A horizon (appendix C2). The amount of soil surface covered by rock ranges from 1 to 25 percent; bare soil ranges from 2 to 34 percent (appendix D).

Vegetative composition.--STCO/BOGR h.t. vegetation (fig. 2) is characterized by an abundance of Stipa comata, the constant presence of Bouteloua gracilis, and the rarity of Agropyron spicatum (appendix E1). At most, the latter species occurs only as widely scattered plants. The amount of Bouteloua gracilis depends upon past use; it usually increases greatly with overgrazing. Artemisia frigida, Gutierrezia sarpthrae, and Opuntia polyacantha, all low shrub life forms, usually are conspicuously present. The most constant though somewhat inconspicuous perennial forb is Sphaeralcea coccinea. This habitat type is floristically simple. Its plant cover consists primarily of grasses, with low cover values of forbs and shrubs (appendix D).
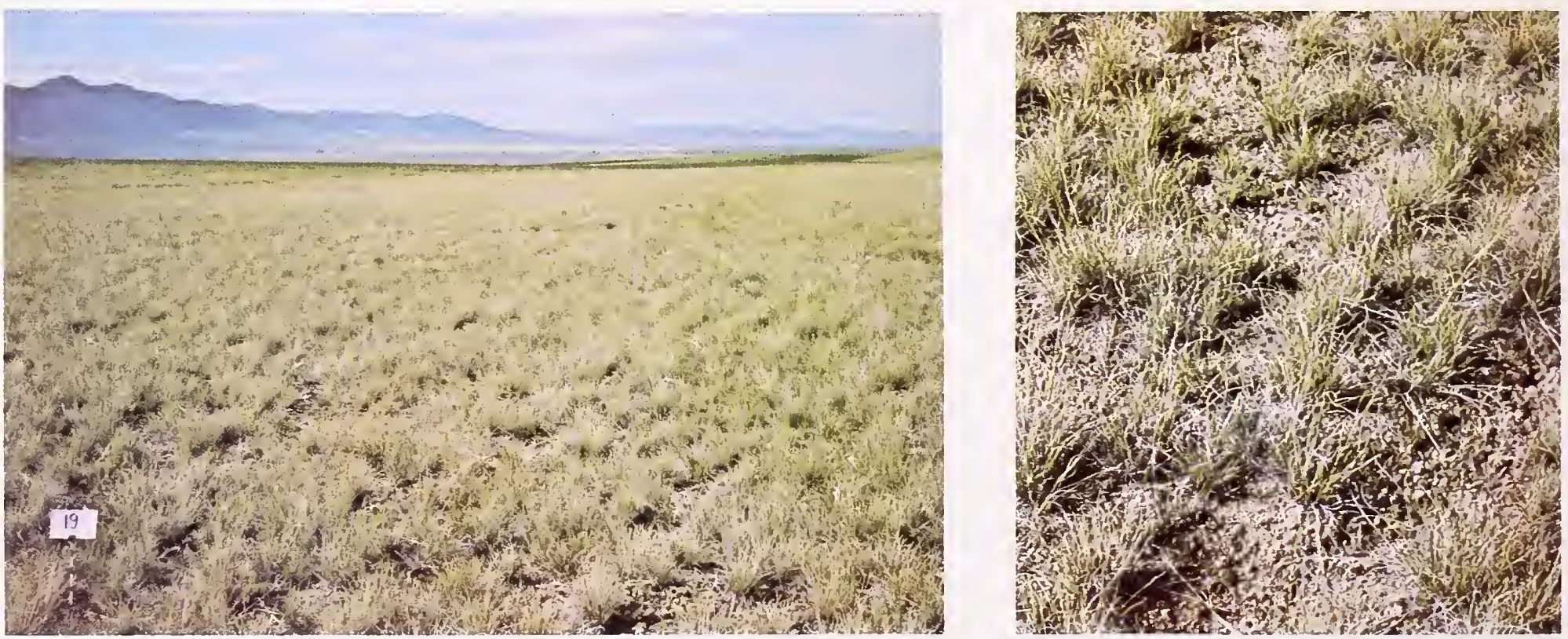

Figure 2.--Stipa comata/Bouteloua gracilis h.t. on a gently sloping alluvial fan near the valley floor at $5200 \mathrm{ft}$. elevation east of Twin Bridges in southwestern Montana. 
The Agropyron smithii phase (AGSM) is a variant of this habitat type that contains a richer and more productive flora with a greater proportion of forbs. The rhizomatous wheatgrasses, Agropyron smithii and Agropyron dasystachyum are important components of its vegetation. Carex filifolia and Koeleria cristata are more constant and abundant, as are such forbs as Chrysopsis vilzosa, Gaura coccinea, Liatris punctata, and Phlox hoodii.

Productivity.--Individual stands within the STCO/BOGR h.t. vary greatly in potential productivity. Stands selected to span the range in production on good condition sites differed over threefold in peak biomass production. This great difference has not been identified positively with specific site characteristics but is probably related primarily to moisture. The more productive sites appear to fall within the Agropyron smithii phase. Production also varies greatly from year to year because of weather. As much as a twofold difference in total biomass on a given stand was measured over a 3-year period. The extremes in production between stands in Montana and a measure of variability between years are presented in table 2 .

Table 2.--Extremes in production and variability over a 3-year period in the Stipa comata/Bouteloua gracilis habitat type

\begin{tabular}{|c|c|c|c|c|}
\hline & & & St & \\
\hline & Average & $\mathrm{SE}^{1}$ & Average & $\mathrm{SE}^{1}$ \\
\hline & $----\cdots$ & Air- & $r e^{2}--$ & ---- \\
\hline Graminoids & 235 & 59 & 699 & 89 \\
\hline Forbs & 5 & 5 & 107 & 46 \\
\hline Shrubs & 1 & 1 & 41 & 41 \\
\hline Total & 241 & 57 & 847 & 128 \\
\hline
\end{tabular}

${ }^{1}$ Standard error over 3-year period.

${ }^{2}$ Multiply by 1.12 for $\mathrm{kg} / \mathrm{ha}$.

Between 42 and 98 percent of the total biomass in three stands sampled for productivity consisted of grasses and sedges. Most of these graminoids (appendix E1) rank from fair to good in palatability (appendix F) and can be considered potential forage. Stipa comata and Bouteloua gracilis are generally the primary producers in this habitat type. The former usually is considered the major forage species; its relative palatability depends upon associated species and declines with maturity. Although the canopy cover of Bouteloua gracilis is often substantial, it does not provide much usable forage because of its low stature. Agropyron smithii, Agropyron dasystachyum, Koeleria cristata, and Carex filifolia may contribute substantially to forage production in the Agropyron smithii phase of this habitat type. These species decline somewhat in palatability as the season progresses; however, fall regrowth is very palatable. Such poor or nonforage species as Phlox hoodii and Opuntia polyacantha seldom comprise a substantial portion of the total biomass unless the area is badly overgrazed.

Herbage yields reported in the literature from sites closely related to the STCO/ BOGR h.t. range from a low of $90 \mathrm{lb} /$ acre $(101 \mathrm{~kg} / \mathrm{ha})$ to a high of 2,400 $1 \mathrm{~b} / \mathrm{acre}(2,690$ $\mathrm{kg} / \mathrm{ha}$ ). The low value was recorded in Canada during the 1930's (Smoliak 1956). The higher rates were recorded from stands in eastern Montana (Woolfolk 1949), western South Dakota (Larson and Whitman 1942), and western North Dakota (Quinnild and Cosby 1958). 
The Canadian data are most applicable to the production potential of the Stipa comata series in western Montana. Smoliak (1956) reported that about 75 percent of the variation in yield can be attributed to yearly difference in May and June precipitation. Studies from Alberta (Smoliak 1960, 1965a, 1965b) and Saskatchewan (Campbel1 and others 1962) suggest that a range similar to this type in excellent condition may produce $480 \mathrm{lb} / \mathrm{acre}(538 \mathrm{~kg} / \mathrm{ha})$ of which $380 \mathrm{lb} / \mathrm{acre}(426 \mathrm{~kg} / \mathrm{ha})$ are graminoids. A similar range in good condition will produce only $3201 \mathrm{~b} / \mathrm{acre}(358 \mathrm{~kg} / \mathrm{ha})$ of which 260 1b/acre $(291 \mathrm{~kg} / \mathrm{ha})$ are graminoids.

Changes with grazing.--Heavy grazing in this habitat type, particularly by cattle and horses, inevitably results in a decrease in such palatable grasses as Agropyron smithii, Agropyron dasystachyum, and Koeleria cristata. Such unpalatable species as Artemisia frigida, Gutierrezia sarothrae, and Opuntia polyacantha are principal increasers. Smoliak (1974) found that although cover of Bouteloua gracilis does not change appreciably with 1ight or moderate use, it increases on heavily grazed ranges. Bouteloua gracilis is a moderately palatable grass, but because of its low stature it can successfully withstand grazing pressure. We consider Bouteloua gracilis a principal increaser in this habitat type. The reaction of Stipa comata, the principal forage producer, to grazing depends upon season and intensity of use, and upon major associated species. It is less palatable than associated Agropyrons and its palatability declines with maturity. Although it is sometimes reported to be an increaser, our observations are that it generally decreases under heavy grazing in this habitat type. Smoliak (1965a) found that leaf length is a better indicator of Stipa comata vigor, and consequently reaction to grazing, than is basal cover.

Evidence accumulated by comparing differentially-grazed communities within the Stipa comata series and by surveying the published literature, suggests the following generalized categorization of species response to grazing in the STCO/BOGR h.t.:

Decreasers

Agropyron dasystachyum

Agropyron smithii

Agropyron spicatum

Koeleria cristata

Oryzopsis hymenoides

Stipa comata

Stipa viriduza
Increasers

Antennaria dimorpha

Artemisia frigida

Bouteloua gracilis

Carex stenophylza

Calamagrostis montanensis

Chrysopsis villosa

Erigeron compositus

Gutierrezia sarothrae

Opuntia polyacantha

Poa sandbergii

Sphaeralcea coccinea

Invaders

Bromus tectorum

Melitotus officinalis

Occasionally Carex filifolia, a fair forage sedge, and Phlox hoodii, a worthless forage species, are prominent in the type. Their response to grazing, however, appears too erratic to permit generalizations. In some cases these species appear to increase with grazing and in other instances to decrease.

Range management.--Cattle and horses are better able to utilize the STCO/BOGR h.t. than sheep because of the prevalence of grasses and lack of palatable forbs. Scarcity of water may limit livestock distribution and, on large areas, result in uneven utilization of forage. The type is most often utilized in early spring before forage becomes available at the higher elevations, and again in late fall and winter after the grasses have cured. The sharp achenes and long, twisted awns of Stipa comata may cause mechanical injury to livestock if grazed after the flower stalks have developed and before the seeds have shattered. Pronghorn antelope may use this type year-1ong; mule deer may use it somewhat during the winter. 
Proposed proper use values for the major grasses differ according to class of livestock; they also differ somewhat by season of use, plant species, and investigators. Reed and Peterson (1961) suggest the following conservative values, expressed as a percentage of total annual growth, for season-long grazing by cattle:

$\begin{array}{ll}\text { Agropyron smithii } & 30 \% \\ \text { Bouteloua gracilis } & 25 \% \\ \text { Stipa comata } & 25 \%\end{array}$

Proper use values recommended by Woolfolk (1949) for season-long sheep grazing and by Holscher and Woolfolk (1953) for cattle winter use are considerably higher:

\begin{tabular}{lccc} 
& \multicolumn{2}{c}{ Season-long } & Winter \\
\cline { 2 - 4 } & Sheep & Cattle & Cattle \\
Agropyron smithii & $20 \%$ & $55 \%$ & $65 \%$ \\
Bouteloua gracilis & $30 \%$ & $45 \%$ & $40 \%$ \\
Stipa comata & $20 \%$ & $60 \%$ & $60 \%$ \\
Carex filifolia & $20 \%$ & $50 \%$ & $50 \%$
\end{tabular}

Woolfolk (1949) indicated that average stubble heights at termination of season-long grazing by sheep should be:

$\begin{array}{ll}\text { Agropyron smithii } & 2.5 \text { in }(6.4 \mathrm{~cm}) \\ \text { Bouteloua gracilis } & 0.5 \text { in }(1.3 \mathrm{~cm}) \\ \text { Carex filifolia } & 1.0 \text { in }(2.5 \mathrm{~cm})\end{array}$

Campbe11 and others (1962) recommended that 20 percent of all seed stalks should remain following grazing of this general type of vegetation.

Upon comparing grazing systems on Great Plains vegetation similar to our Stipa comata series, Rogler (1951) found that rotation grazing is not superior to continuous grazing for maintaining good condition range. Furthermore, he found continuous grazing resulted in greater gains of yearlings or 2-year-old steers than did rotation grazing. He concluded that although rotation grazing may benefit overgrazed range of this type, complete deferment until recuperation would lead to more rapid and satisfactory improvement. Hubbard (1951), working in Alberta, also found that although deferred rotation grazing may improve depleted ranges of this type, it does not benefit ranges already in good condition. He concluded that conservative continuous grazing is the most practical management. Prolonged heavy sheep grazing in this type can cause forage deterioration by permitting an increase in Bouteloua gracilis and decrease in the more productive Agropyron smithii and Stipa comata. For Alberta conditions, Smoliak (1974) recommended that sheep stocking rates under a continuous grazing system not exceed one sheep-month per acre. Possibly a rest-rotation grazing system tailored to specific conditions may permit efficient use of this habitat type.

Overall productivity of this type of range can be increased by nitrogen fertilization. In the Northern Great Plains, applying 30 to $501 \mathrm{~b} / \mathrm{acre}$ ( 34 to $56 \mathrm{~kg} / \mathrm{ha}$ ) of $\mathrm{N}$ commonly doubled total herbage production (Wight 1976). However, such an increase in total herbage biomass does not necessarily mean an equivalent increase in production of palatable forage. Such poor to fair forage species as Phlox hoodii, Artemisia frigida, and Taraxicum officinale may provide the bulk of the increase (Klages and Ryerson 1965). The rhizomatous wheatgrasses usually respond more favorably to fertilization than the less desirable BouteZoua gracilis (Smoliak 1965b; Lorenz and Rogler 1972). Effects of the fertilizers can carry over into subsequent years in this relatively dry type. Smoliak (1965b) noted significant increases in production 8 years following fertilization 
on the Northern Great Plains. When fertilization is accompanied by spraying with 2,4-D to control forbs, a significant increase in grass forage usually can be expected (Smika and others 1963). Although range pitting and interseeding may increase forage production, it does not appear to be economical in this type (Wight and White 1974).

Strategically located water developments and placement of salt can markedly enhance uniform use of the large expanses of range commonly occupied by this habitat type.

Noted elsewhere.--Ross and others (1973) described several stands of vegetation in eastern Montana that appear similar in composition to the STCO/BOGR h.t. Coupland (1961) described a Stipa-BouteZoua faciation of the mixed prairie in southern Saskatchewan and Alberta that is also very similar to our western Montana STCO/BOGR h.t. Coupland's faciation was limited to sandy soils on dry sites. The main species difference appears to be the occurrence of Artemisia cana in the Canadian vegetation.

What appears to be an environmental counterpart in eastern Washington was identified by Daubenmire (1970) as the Stipa comata/Poa sandbergii h.t. His type, however, lacks certain major species associated primarily with the flora of the Great Plains. Important species in the STCO/BOGR h.t. not occurring in the eastern Washington type are Bouteloua gracilis, artemisia frigida, Carex stenophylza, Gurierrezia sarothrae, and Sphaeralcea coccinea.

\title{
Agropyron spicatum/Bouteloua gracilis h.t.
}

\author{
$(A G S P / B O G R$ h.t.)
}

Distribution and environment.--The AGSP/BOGR h.t. is found east of the Continental Divide on toeslopes of the foothills and steeper slopes off the valley bottoms. The lower edge of the type commonly abuts the STCO/BOGR h.t. The STCO/BOGR h t . occurs primarily on the more southerly exposures on slopes up to 35 percent and at elevations usually less than $6,000 \mathrm{ft}(1,800 \mathrm{~m})$. This habitat type is somewhat less arid than the STCO/BOGR h.t.; estimated precipitation ranges from about 12 in to as high as 18 in (30 to $46 \mathrm{~cm})$, but potential evapotranspiration is high.

Soils from representative examples of the AGSP/BOGR h.t. are Typic Argiborolls and Entic Haploborolls. They are of both ustic and aridic moisture and of frigid temperature regimens (Munn and others 1978). The type occurs on a great diversity of parent materials. Thickness of the soil solum varies greatly, with a 4 to 7 in (10 to $18 \mathrm{~cm}$ ) A horizon (appendix C2). The solum is neutral in reaction ( $\mathrm{pH} \mathrm{7.1),} \mathrm{with} \mathrm{free} \mathrm{calcium}$ carbonates generally restricted to depths greater than 6 in $(15 \mathrm{~cm})$. The soils appear relatively nitrogen-poor and have a high C:N ratio compared to other habitat types (appendix C3). The amount of surface rock varies appreciably, from 1 to 46 percent; bare soil varies from 1 to 42 percent (appendix D).

Vegetative composition.--Agropyron spicatum shares dominance with Stipa comata (fig. 3). As in the STCO/BOGR h.t., Bouteloua gracilis is always present, but in varying amounts depending upon grazing history. Generally, it is a conspicuous and important part of the flora with a potential to increase substantially under heavy grazing. Usually Koeleria cristata, Poa sandbergii, and Carex stenophylla are also present. Phlox hoodii and Sphaeralcea coccinea are the most constant forbs. Artemisia frigida is always present and conspicuous; Gutierrezia sarothrae and Opuntia polyacantha, also lowgrowing shrubs, are usually present (appendix E2). The AGSP/BOGR h.t. may contain several species of medium-tall shrubs, but they are seldom abundant. The most constant of these shrubs is Chrysotharmus nauseosus. Grasses form by far the greatest part of the total vegetation cover (appendix D). Forbs and shrubs, however, are somewhat more abundant than in the STCO/BOGR h.t. 
The richer flora occuring within the Liatris punctata phase (Lipun) of the AGSP/ BOGR h.t. probably reflects a slightly more productive site. This phase is characterized by the presence of either Liatris punctata, or Carex filifolia and Calamagrostis montanensis. The conspicuous forb Chrysopsis villosa is also more consistently present.
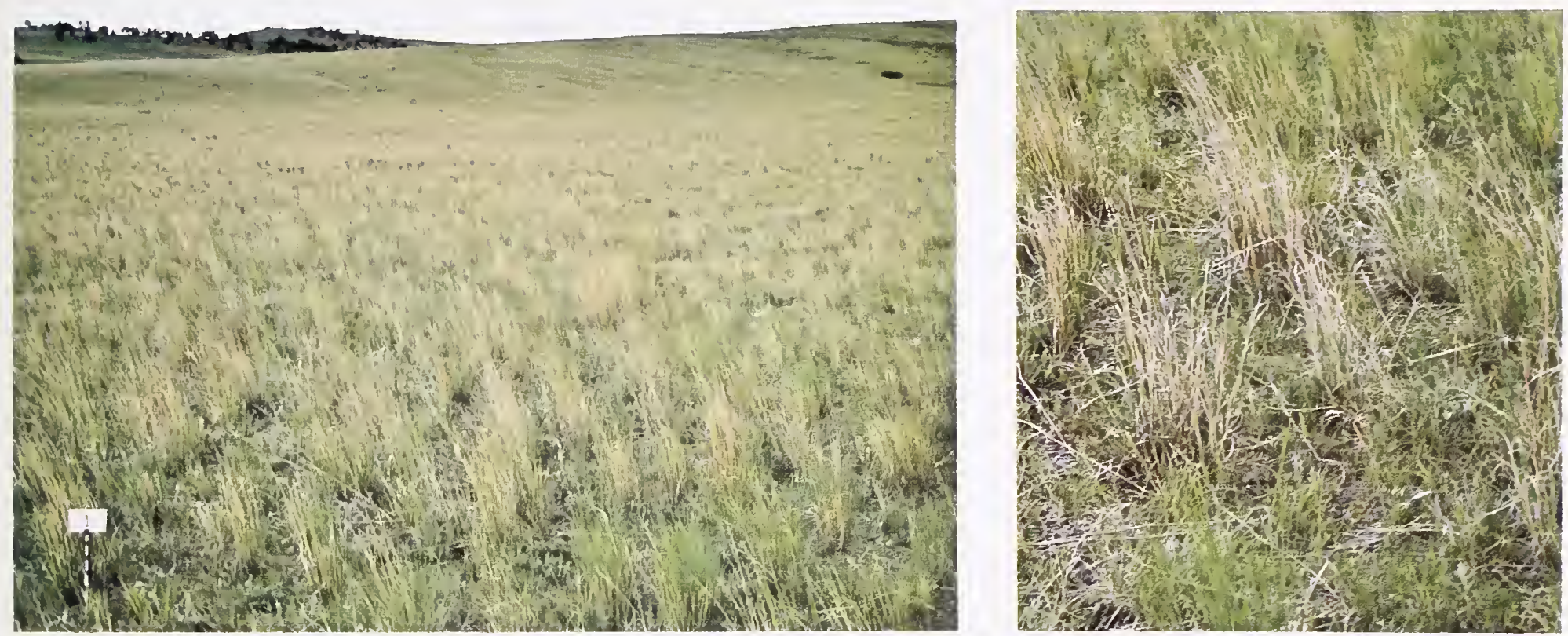

Figure 3.--Agropyron spicatum/Bouteloua gracilis h.t. on a gentle west-facing slope, 5,000 ft, elevation, in the foothills west of Bozeman in southwestern Montana.

Productivity.--Although overall productivity of this type does not differ greatly from that of the STCO/BOGR h.t., the vegetation is composed of more desirable, forage. Individual stands within the $A G S P / B O G R \mathrm{~h} . \mathrm{t}$. can differ considerably in productivity because of both site conditions and yearly weather differences. Stands purposefully selected in western Montana to span the range in site-induced differences in productivity indicate that the better sites are capable of producing twice as much as the poorer sites. Site potential within the habitat type appears related to soil depth and consequently soil moisture storage capacity. Weather variations over a 3-year period caused as much as 180 percent difference in herbage production. The extremes in productivity between stands in the $A G S P / B O G R$ h.t., and a measure of variability attributable to weather differences between years are presented in table 3 .

Table 3.--Extremes in production and variability over a 3-year period in the Agropyron spicatum/Bouteloua gracilis habitat type

\begin{tabular}{|c|c|c|c|c|}
\hline \multirow[b]{2}{*}{ Growth form } & \multicolumn{2}{|c|}{ Stand 9} & \multicolumn{2}{|c|}{ Stand 179} \\
\hline & Average & SEl & Average & $\mathrm{SE}^{1}$ \\
\hline & --- & $-A i 1$ & ${ }^{2}---$ & - \\
\hline Graminoids & 243 & 24 & 467 & 47 \\
\hline Forbs & 117 & 15 & 310 & 102 \\
\hline Shrubs & 71 & 37 & 63 & 44 \\
\hline Total & 431 & 47 & 773 & 127 \\
\hline
\end{tabular}

\footnotetext{
${ }^{1}$ Standard error over 3-year period.

${ }^{2}$ Multiply by 1.12 for $\mathrm{kg} / \mathrm{ha}$.
} 
At least half (50 to 60 percent) of this total biomass consists of graminoids which are rated fair to good in palatability (appendixes E2, F). Agropyron spicatum and Stipa comata are the primary forage producers. Koeleria cristata, Poa sandbergii, and Carex spp. may contribute substantially to forage production. Although Bouteloua gracilis is usually conspicuous in the type, it produces little usable forage because of its low stature.

Forbs as a group can constitute approximately 30 percent of the total biomass. No single species, however, is noted as a major producer of palatable forage. The more abundant forbs, such as Phlox hoodii, and Chrysopsis vizlosa are often poor forage species. The most consistent and abundant shrub, Artemisia frigida, is considered, at best, only fairly palatable.

Changes with grazing.--Many others (Daubenmire 1940; E11ison 1960; Mc Lean and Marchand 1968) concluded as we have that Agropyron spicatum is a major forage species that declines with excessive grazing in the Agropyron spicatum series. Mueggler (1972a) found that a decrease in flower stalk numbers is a more sensitive indicator of vigor decline in this grass than either herbage production or leaf and flower stalk lengths. Principal species that increase with overgrazing are Artemisia frigida, Bouteloua gracilis, and Gutierrezia sarothrae. Usually Stipa comata will tend to increase with the decline of Agropyron spicatum. If overgrazing persists, Stipa comata too will decline. Artemisia tridentata and Chrysothamms spp., normally incidental shrubs on good condition range of this type, may increase to a level of dominance under extreme abuse.

The following 1ist of species and their response to overgrazing in the Agropyron spicatum series was developed from our comparisons of differentially grazed stands and from reviewing appropriate literature:

Decreasers

Agropyron spicatum

Liatris punctata

Lygodesmia juncea

Oxytropis riparia

Potentizla pennsyzuanica

Stipa vimidula
Increasers

Antennaria dimorpha

Artemisia frigida

Artemisia tridentata

Bouteloua gracilis

Carex stenophyzla

Chrysopsis villosa

chrysotharmus nauseosus

Chrysothamms viscidifloms

Erigeron filifolius

Galium boreale

Grindelia squarrosa

Gutierrezia sarothrae

Helictotrichon hookeri

Hymenoxys acaulis

Lesquerella alpina

Lupinus semiceus

Paronychia sessilifolia

Poa sandbergii

Sphaeralcea coccinea

sporobolus cryptandrus
Invaders

Bromus japonicus

Bromus tectorum

Centaurea maculosa

Cirsium vulgare

Taraxicum officinale

Tragopogon dubius 
Although we have stated that Artemisia frigida and Bouteloua gracilis are principal "increasers," they do not always behave this way. In our paired-stand grazing comparisons (appendix G2), canopy cover of Artemisia frigida is significantly greater in stand 194, which is inside of an exclosure and has been protected from grazing for about 10 years, than in stand 195 which is outside and is grazed by cattle. Both areas appear to have been heavily grazed by sheep in the past. Canopy cover of Bouteloua gracilis is significantly greater in stand 13, moderately grazed by cattle and horses, than in the immediately adjacent stand 12 , which is heavily grazed by cattle and horses. These two stands also were probably grazed heavily by sheep prior to about 1950. More typically, however, overgrazing enhances the enlargement of mats of Bouteloua gracilis, and greatly increases the numbers of Gutierrezia sarothrae and Artemisia frigida.

Agropyron smithii, Agropyron dasystachyum, Koeleria cristata, Stipa comata, and Phlox hoodii are often prominent species in the Agropyron series. However, we have not been able to generalize on their response to grazing because of extreme inconsistency.

Range management.--The AGSP/BOGR h.t. is more suitable for use by cattle and horses than it is for sheep. Palatable grasses are usually abundant, but palatable forbs are relatively scarce. A greater amount of forbs enhances the value of the liatris punctata phase as sheep range. Lack of adequate stock water may limit use during the summer and early fall periods. The awns of Stipa comata, which is usually abundant in this type, may cause mechanical injury to livestock if grazed in late spring and early summer. Consequently this low elevation type is best suited for spring and late fall grazing. Use during early summer should be intermittent and moderate. Primary big game use is by pronghorn antelope and as winter range for mule deer. The type is also used somewhat by elk during winter.

Management of this habitat type should be directed specifically at Agropyron spicatum. It is the major forage producer and is also sensitive to abusive grazing. The most crucial period of use for this grass appears to be after the date when substantial regrowth is impossible yet before the plant matures, or about the flowering growth stage (Blaisdell and Pechanec 1949). At this time carbohydrate reserves in the roots are low and the plant is usually unable to produce regrowth because soil moisture is limiting. Heavy utilization and lack of regrowth leaves the plant without the means for producing carbohydrates to build up the root reserves. Wilson and others (1966a) found that Agropyron spicatum was most sensitive to clipping when in the boot stage of floral development.

Average stubble height of grasses at the end of the grazing season is often used as an indicator of proper use. Heady (1950) found that Agropyron spicatum clipped to a 6 -in $(15-\mathrm{cm})$ stubble height or less at the time of flowering suffered vigor losses the following year. A 6 -in stubble height represented 40 to 60 percent weight removal, depending upon original height of the plant. Mueggler (1972a) found that a 50 percent weight removal just before full emergence of inflorescence caused a 50 percent reduction in total weight and 95 percent reduction in flower stalk numbers the following growing season. When competition from surrounding vegetation was reduced by clipping, the vigor loss in Agropyron spicatum was neither as immediate nor as great but was still substantial. Obviously, less than 50 percent, perhaps no more than 30 percent, of current growth should be utilized if this species is grazed during the peak of growth. McLean and Marchand (1968) indicate that grazing Agropyron spicatum in the spring should not occur until the grass is at least 4 in $(10 \mathrm{~cm})$ high. They state that root reserves of this grass are minimal when the tops are 7 in $(18 \mathrm{~cm})$ high. Consequently, early spring grazing must be terminated in time to permit additional growth and storage of food reserves in the roots. Utilization may be as much as 50 or 60 percent, or even greater, if grazed after Agropyron spicatum has cured in late summer or fall. McIlvanie (1942) found that maximum amounts of carbohydrates were stored as root reserves about 2 months after appearance of the flower stalks. Late season grazing, therefore, should not seriously harm the potential for overwintering and growth initiation the following year. If an Agropyron spicatum-dominated range is in poor condition, grazing should be deferred until fall or early winter to permit the plants to regain vigor. 
Various studies have shown that the number of flower stalks is a sensitive indicator of vigor in Agropyron spicatum (Blaisde11 and Pechanec 1949; Mueggler 1972a). However, further studies (Mueggler 1975) revealed that maximum lengths of flower stalks may actually be a more reliable indicator of initial vigor loss than numbers of flower stalks. Evaluation of vigor requires comparison with protected (ungrazed) plants of normal vigor because both numbers and lengths of flower stalks vary greatly between years because of weather. Once the vigor of Agropyron spicatum is lowered, recovery can be very slow. Mueggler (1975) concluded that moderately low vigor Agropyron spicatum in a FEID/AGSP h.t. may require at least 6 years of protection to recover fully; complete recovery of very low vigor plants can take more than 8 years of protection.

Fertilization may increase overall production within the AGSP/BOGR h.t., but this practice is of questionable economic value. Unpalatable forbs tend to respond as readily as the grasses to nitrogen fertilization. Consequently, full benefit of fertilization for improved forage production on native vegetation usually can be obtained only if accompanied by herbicide treatment to control the unwanted forbs and shrubs. Fertilization of ranges in the Agropyron spicatum series that contain Bromus tectomum as a component of the vegetation could result in a substantial decrease in Agropyron spicatum. Wilson and others (1966b) found that applying nitrogen at the rate of 80 $1 \mathrm{~b} /$ acre $(90 \mathrm{~kg} / \mathrm{ha})$ for 4 consecutive years resulted in a 50 percent reduction in yield of Agropyron spicatum and a 400 to 600 percent increase in Bromus tectorm.

Noted elsewhere.--At least 11 stands of near pristine vegetation described by Ross and others (1973) for the sedimentary plains and foothill areas throughout Montana have the same species composition as the AGSP/BOGR h.t. A11 of these stands are within the 10 - to 14 -in $(25-$ to $35-\mathrm{cm})$ precipitation zone, and occur primarily on relatively shallow, sandy-loam soils.

\title{
Agropyron spicatum /Agropyron smithii h.t.
}

\author{
(AGSP/AGSM h.t.)
}

Distribution and environment.--This habitat type occurs most frequently east of and only occasionally west of the Continental Divide. Generally it.is found at elevations between 4,000 and 5,700 ft $(1,200$ and $1,700 \mathrm{~m})$, and on a11 exposures. A1though it can occur on slopes as steep as 40 percent, most of the time it will be found on slopes less than 20 percent. The Stipa viridula phase (STVI) is associated with the slightly steeper slopes. The AGSP/AGSM h.t. is moderately arid, usually occurring within the 12 - to 18 -in $(30-$ to $46-\mathrm{cm})$ precipitation zone.

Soils were analyzed in detail from two typical examples of the type. Both are Entic Haploborolls; one is of an ustic and the other an aridic moisture regimen; both are of a frigid temperature regimen (Munn and others 1978). Solum thickness of the two soils averages 11 in $(28 \mathrm{~cm})$ with a 9 -in $(22-\mathrm{cm})$ A horizon. Solum pH is neutral, with free calcium carbonate not reached until 7 in $(18 \mathrm{~cm})$. Surface rock cover of 16 stands sampled in this type ranges widely from 1 to 70 percent; bare soil ranges from 1 to 32 percent (appendix D). The type does not appear restricted to any particular soil parent materials.

Vegetative composition.--A definite grassland aspect, the dominance of Agropyron spicatum, the abundance of rhizomatous wheatgrasses (Agropyron smithii and/or Agropyron dasystachyum), and the lack of Bouteloua gracilis characterize the AGSP/AGSM h.t. (fig 4). If present, Bouteloua gracilis is usually inconspicuous and unable to increase substantially with overgrazing. Other important grasses include Koeleria cristata, Stipa comata, and either Poa sandbergii or Poa cusickii. The low shrubs Artemisia frigida and Gutierrezia sarothrae are usually present and may be abundant. 

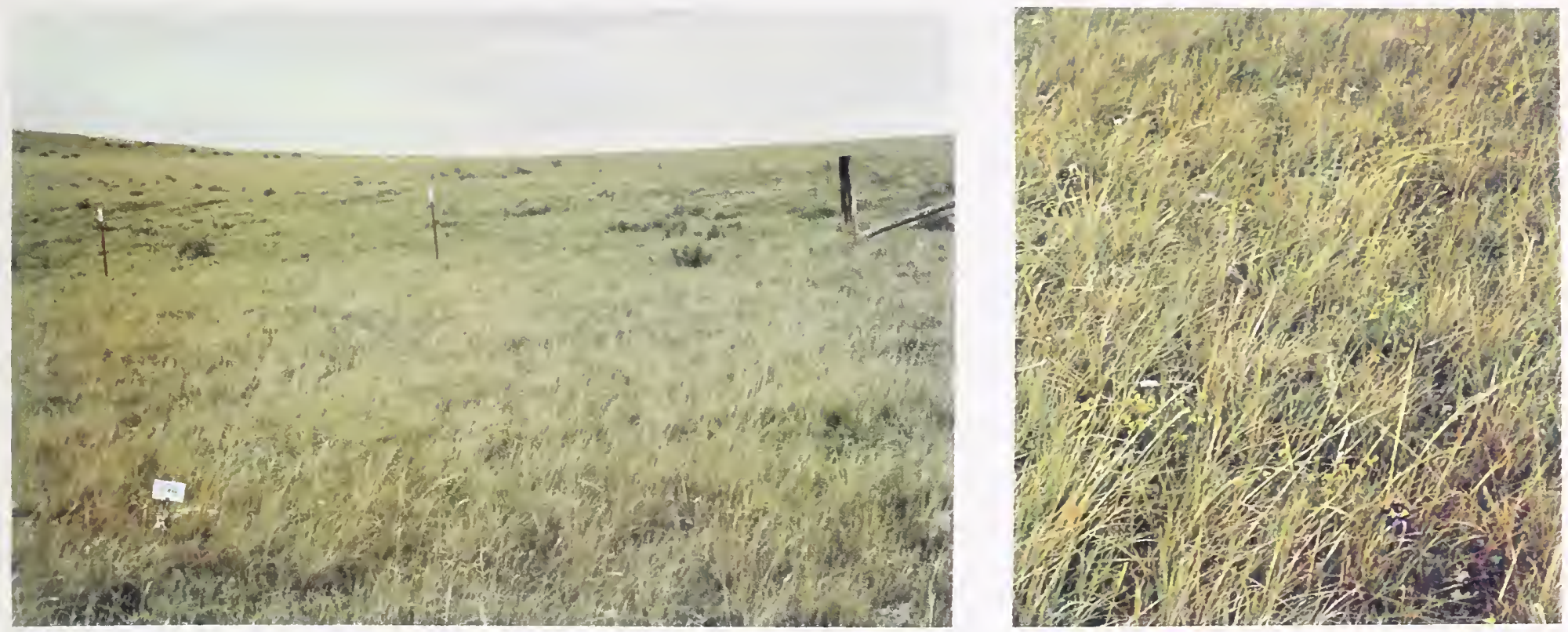

Figure 4.--Agropyron spicatum/Agropyron smithii h.t. on a gentle southwesterly slope at 5,100 ft. elevation where the plains meet the mountains near Judith Gap in Central Montana.

Medium tall shrubs are not prominent. Forbs are generally much more diverse and important here than in the AGSP/BOGR h.t. Chrysopsis villosa, Phlox hoodii, Spaeralcia coccinea, and Tragopogan dubius are the most constant and conspicuous forbs (appendix E2).

The Stipa viridula phase is characterized by the presence and often abundance of this grass. Vicia americana is a prominent forb usually confined to this phase.

Productivity.--Judging from the stands selected to span the range in forage potential within this habitat type, productivity varies more between years than between stands. Differences in total biomass between stands averaged about 20 percent over a 3-year period. Differences between years attributable to weather amounted to 54 percent in one stand and 67 percent in another. Typical productivity values for extreme stands are presented in table 4.

Table 4.--Extremes in production and variability over a 3-year period in the Agropyron spicatum/Agropyron smithii habitat type

\begin{tabular}{|c|c|c|c|c|}
\hline \multirow[b]{2}{*}{ Growth Form } & \multicolumn{2}{|c|}{ Stand 83} & \multicolumn{2}{|c|}{ Stand 248} \\
\hline & Average & SEl & Average & $\mathrm{SE}^{1}$ \\
\hline & --- & $-A i r$ & $e^{2}-\cdots$ & - \\
\hline Graminoids & 488 & 64 & 742 & 107 \\
\hline Forbs & 191 & 54 & 60 & 21 \\
\hline Shrubs & 2 & 2 & 1 & 1 \\
\hline Total & 680 & 94 & 803 & 116 \\
\hline
\end{tabular}

${ }^{1}$ Standard error over 3-year period.

${ }^{2}$ Multiply by 1.12 for $\mathrm{kg} / \mathrm{ha}$. 
More than two-thirds of the total biomass consists of grasses and sedges. Agropyron spicatum is the major forage producer. Other important forage species include Stipa comata, Agropyron smithii, Agropyron dasystachyum, Koeleria cristata, and Poa cusickii (appendixes E2, F). Stipa viridula generally produces a substantial amount of forage in the Stipa viridula phase of this habitat type.

Although numerous species of forbs may be present, they do not contribute very much to forage production. They usually are neither abundant nor palatable. Vicia comericana is an exception; it can be a productive forage species in the Stipa viridula phase. Artemisia frigida is often abundant, but is only fairly palatable.

Changes with grazing.--Expected reactions of plant species to abusive grazing within the Agropyron spicatum series are covered in the AGSP/BOGR h.t. description. Generally, Agropyron spicatum and Stipa viridula are the principal decreasers within the AGSP/AGSM h.t. Agropyron smithii and Agropyron dasystachyum, two rhizomatous wheatgrasses, and Stipa comata usually increase as Agropyron spicatum decreases; however, they too will decrease with continued heavy grazing. Artemisia frigida, Gutierrezia sarothrae, and Chrysopsis vilzosa are the principal species that increase with overgrazing. Seemingly, Phlox hoodii should increase also because of its low matted growth form and lack of palatability, but it responds erratically. We can expect a substantial increase in Opuntia polyacantha, Artemisia tridentata, and Chrysothamus spp. in this type if overgrazing persists.

Range management.--Considerations in managing this habitat type are similar in many ways to those discussed for the AGSP/BOGR h.t. Agropyron spicatum is a primary forage producer and the environmental situations do not differ greatly. Both types are best suited as cattle range. The major difference that concerns management of these two types is the abundance of the rhizomatous Agropyron smithi $i$ and/or Agropyron dasystachyum and the relative scarcity of the mat-forming Bouteloua gracilis in the AGSP/AGSM h.t. These rhizomatous wheatgrasses are better able to withstand heavy grazing than Agropyron spicatum. If Agropyron spicatum declines, the rhizomatous wheatgrasses usually increase. Thus forage production tends to be maintained. However, if abusive grazing continues, the rhizomatous wheatgrasses also will suffer, as will total forage production. Everson (1966) suggests that utilization of Agropyron smithii should not exceed a 4 -in $(10-\mathrm{cm})$ stubble height to maintain good vigor. In one case, moderate continuous grazing over a 34-year period did not appreciably harm Agropyron smithii (Rogler 1951). Buwai and Trlica (1977), however, propose a rest-rotation grazing system for such semiarid ranges to insure that grazed plants such as Agropyron smithii receive rest following grazing during critical growth periods.

Fertilization, mechanical treatment, and waterspreading may be ways of improving forage production in this habitat type under the proper circumstances. Goetz (1970) found that the vigor of Agropyron smithii can be increased by application of $671 \mathrm{~b} / \mathrm{acre}$ $(75 \mathrm{~kg} / \mathrm{ha})$ nitrogen. In eastern Montana on Agropyron smithii- and Bouteloua gracilisdominated sites, Houston (1960) found that waterspreading is economically feasible, given the right combination of topography and access to a supplemental source of water. He determined that flooded sites produced 62 percent more herbage and ponded sites 189 percent more herbage than areas where supplemental water was not added. Species composition did not change on sites dominated by Agropyron smithii. In Houston's study, the annual gross returns per acre were approximately seven times the annual per acre cost of the system. Where clubmoss (Selaginelza densa) is a problem, mechanical treatment such as chiseling or disking may decrease the clubmoss and improve forage production on sites with Agropyron smithii cover (Dolan and Taylor 1972).

Noted elsewhere.--Ross and others (1973) described at least 16 near-pristine stands scattered throughout central and eastern Montana that appear to fall within the AGSP/AGSM h.t. Ten of these were in foothill areas and six were on the sedimentary plains. All but one were in the $10-$ to $16-$ in $(25-$ to $40-\mathrm{cm})$ precipitation zone and occurred on fine-sandy to clay-loam soils. 


\title{
Agropyron spicatum/Poa sandbergii (MONT) h.t.
}

\author{
$(A G S P / P O S A N$ h.t.)
}

Distribution and environment.--Though not abundant, the AGSP/POSAN h.t. can be found scattered throughout western Montana. Usually it occurs at elevations between 3,000 and $6,000 \mathrm{ft}(900$ and $1,800 \mathrm{~m})$. It can be found on any exposure and on gentle as well as very steep slopes. The type occurs on loamy soils derived from a wide variety of parent materials. It is considered a moderately arid type, probably falling within the 14 - to 20 -in $(36-$ to $56-\mathrm{cm})$ precipitation zone. In the eight stands sampled, the amount of bare soil ranges from 1 to 30 percent and the amount of soil surface covered by rock ranges from 1 to 59 percent (appendix D).

Vegetative composition.--This grassland habitat type is clearly dominated by Agropyron spicatum (fig 5); Poa sandbergii and Koeleria cristata are constant species of secondary importance. Neither rhizomatous Agropyron spp. nor Bouteloua gracilis are important. A Stipa comata phase (STCO) is recognized where either Stipa comata or Stipa spartea share dominance with Agropyron spicatum. The habitat type has a wide variety of forbs which, as a class, sometimes comprise 30 to 40 percent canopy cover (appendix D); yet, no one forb constantly shares dominance with Agropyron spicatum (appendix E2). Balsamorhiza sagittata, a forb not present in previously described habitat types, is locally abundant in some communities of this type west of the Continental Divide. As with the other habitat types within the Agropyron spicatum series, Artemisia frigida and Gutierrezia sarothrae are the most prevalent low shrubs. Medium shrubs, such as Chrysothamus nauseosus and Chrysothamus viscidifloms are sometimes present but do not form a major part of the undisturbed community.
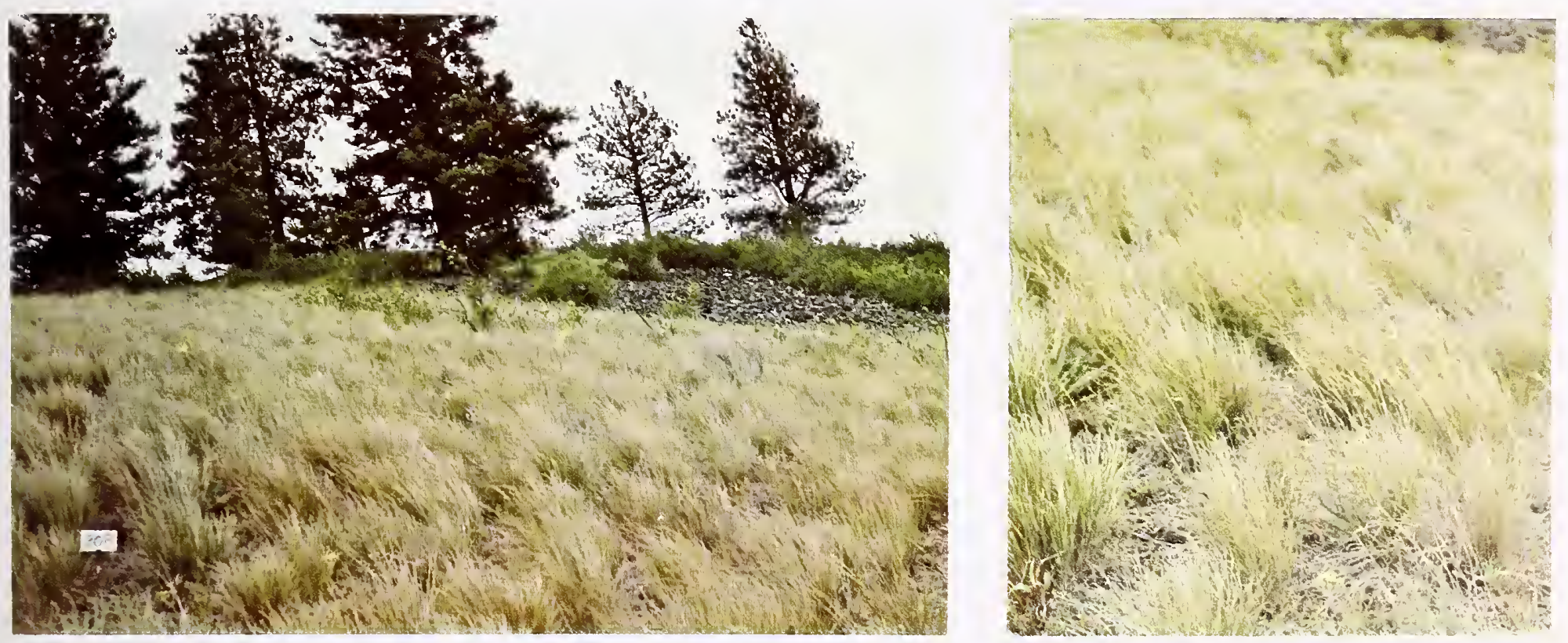

Figure 5.--Agropyron spicatum/Poa sandbergii h.t. on a 40-percent southwest slope at 4,200 ft elevation east of Lonepine in northwestern Montana.

Productivity.--We did not measure the productivity of this habitat type in western Montana. However, productivity measures are available for similar range types in other areas. 
Anderson (1956) reports that production from similar vegetation in eastern Oregon ranges between $200 \mathrm{lb} / \mathrm{acre}(224 \mathrm{~kg} / \mathrm{ha})$ on sandy soils to $500 \mathrm{lb} / \mathrm{acre}(560 \mathrm{~kg} / \mathrm{ha})$ on silty-loam soils. The major forage producers were Agropyron spicatum (20 to 65 percent), Poa sandbergii (20 to 25 percent), Stipa spp. (5 to 30 percent), and perennial forbs (5 to 10 percent).

For south central British Columbia, McLean and Marchand (1968) report yields of 420 to $500 \mathrm{lb} / \mathrm{acre}(470$ to $560 \mathrm{~kg} / \mathrm{ha}$ ) for good to excellent range of this type. Agropyron spicatum, Stipa comata, Poa sandbergii, and Artemisia frigida were the primary producers.

In western Montana we can expect that good condition range in the AGSP/POSAN h.t. will probably produce between 300 and $500 \mathrm{lb} /$ acre (336 to $672 \mathrm{~kg} / \mathrm{ha}$ ) total air-dry vegetation. Approximately 70 to 80 percent of this will consist of grasses that are good to excellent in palatability. However, if Stipa comata is abundant, value for mid-season grazing will be reduced because of possible mechanical damage to livestock from the awns of this species (Stoddart and Smith 1955).

Changing with grazing.--General reactions of species to overgrazing in the Agropyron spicatum series are discussed in the AGSP/BOGR h.t. section. Under heavy cattle or horse grazing, Agropyron spicatum is the principal forage species to decrease. Daubenmire (1940) found that this kind of use in the AGSP/POSAN h.t. in eastern Washington resulted in a marked decline of Poa sandbergii as well, but Poa sandbergii increased appreciably when the type was heavily grazed by sheep. The reverse appears to be true for Balsamorhiza sagittata. We have observed that where present in appreciable amounts, Balsamorphiza sagittata will usually increase when the type is grazed by cattle or horses and decrease substantially when grazed in the spring or early summer by sheep. Fall grazing is not detrimental to this forb (Mueggler 1950; Laycock 1967). Very likely Stipa comata will increase initially with a decline in the more palatable species, but it too will decline with continued heavy use. Artemisia frigida and Gutierrezia sarothrae usually increase conspicuously with overgrazing. Artemisia tridentata and Chrysotharmus spp. may eventually become dominant on badly depleted ranges of this type. Bromus tectomm and Centaurea maculosa are often conspicuous invaders in the AGSP/POSAN h.t.

Range management.--Livestock management in the AGSP/POSAN h.t. should be keyed primarily to the grazing sensitivity of Agropyron spicatum, as discussed in management for the AGSP/BOGR h.t. Where Balsamorhiza sagittata is prominent in the community, management of sheep grazing should be keyed to the growth requirements of this robust and productive forb. Blaisdell and Pechanec (1949) found that Balsamorhiza sagittata is most susceptible to damage from grazing when it is in full bloom. Heavy clipping at this time reduced herbage production the following year by 60 percent and reduced the number of flower stalks almost 95 percent. Grazing earlier in the season, before the appearance of flower stalks, or later, after the plants had cured, is not nearly as damaging. As with Agropyron spicatum, the detrimental effect of grazing Balsamorhiza sagittata apparently depends on the amount of herbage left to manufacture food for storage in the roots during the period prior to drying.

Noted elsewhere.--Daubenmire (1970) described Agropyron spicatum/Poa secunda (sandbergii) h.t. for eastern Washington that lacks the species diversity of our Montana AGSP/POSAN h.t. This type does not contain such species as Artemisia frigida, Phlox hoodii, Chrysopsis vilzosa, Gutierrezia sarothrae, Gaura coccinea, and Koeleria cristata, which are common to our type. Also, Stipa comata is very conspicuous in our Stipa comata phase, but is generally lacking in the eastern Washington type. 


\title{
Festuca scabrella /Agropyron spicatum h.t.
}

\author{
(FESC/AGSP h.t.)
}

Distribution and environment.--Festuea scabrella occurs on both sides of the Continental Divide but is widespread only in western Montana north of approximately $46^{\circ}$ latitude. Outliers of the species extend as far south as the Gravelly and Madison mountain ranges (Stickney 1960). The FESC/AGSP h.t., therefore, is confined primarily to the northern half of the state. It occurs at elevations between approximately 3,000 and $6,000 \mathrm{ft}(900$ and $1,800 \mathrm{~m})$, on both level topography and steep slopes, and on a11 exposures. Stands west of the Divide are generally below 4,000 ft $(1,200 \mathrm{~m})$ elevation. It is a moderately arid habitat type.

Soils from two stands representing the FESC/AGSP h.t. were classified as fine Vertic Agriborol1 of ustic moisture and frigid temperature regimens, and as fine-1oamy Entic Haploboroll of aridic moisture and frigid temperature regimens (Munn and others 1978). The soil solums have neutral pH, with free calcium carbonates at depths greater than 10 in $(26 \mathrm{~cm})$. Soil depth is variable, with an A horizon ranging at least from 6 to 10 in $(15$ to $25 \mathrm{~cm})$, and solum from 10 to 17 in $(25$ to $43 \mathrm{~cm})$. The amount of surface rock averages about 5 percent, as does the amount of bare soil (appendix D). The habitat type is not confined to any particular soil parent material.

Vegetative composition.--This is an obvious grassland type conspicuously dominated by Festuca scabrella (fig. 6). Both Agropyron spicatum and Festuca idahoensis are generally abundant; however, Festuca idahoensis may be absent on some areas east of the Divide. In fact, somewhat different overall species composition exists between communities of this type found east and west of the Divide. Artemisia frigida, Chrysopsis villosa, Gutierrezia sarothrae, Stipa comata, Bouteloua gracilis, Muhlenbergia cuspidata, Liatris punctata, and Artemisia Zudoviciana are either more common or present only east of the Divide. West of the Divide, Balsamorhiza sagittata, Besseya wyomingensis, Castelleja Zutescens, and Lomatium tritematum are more common.
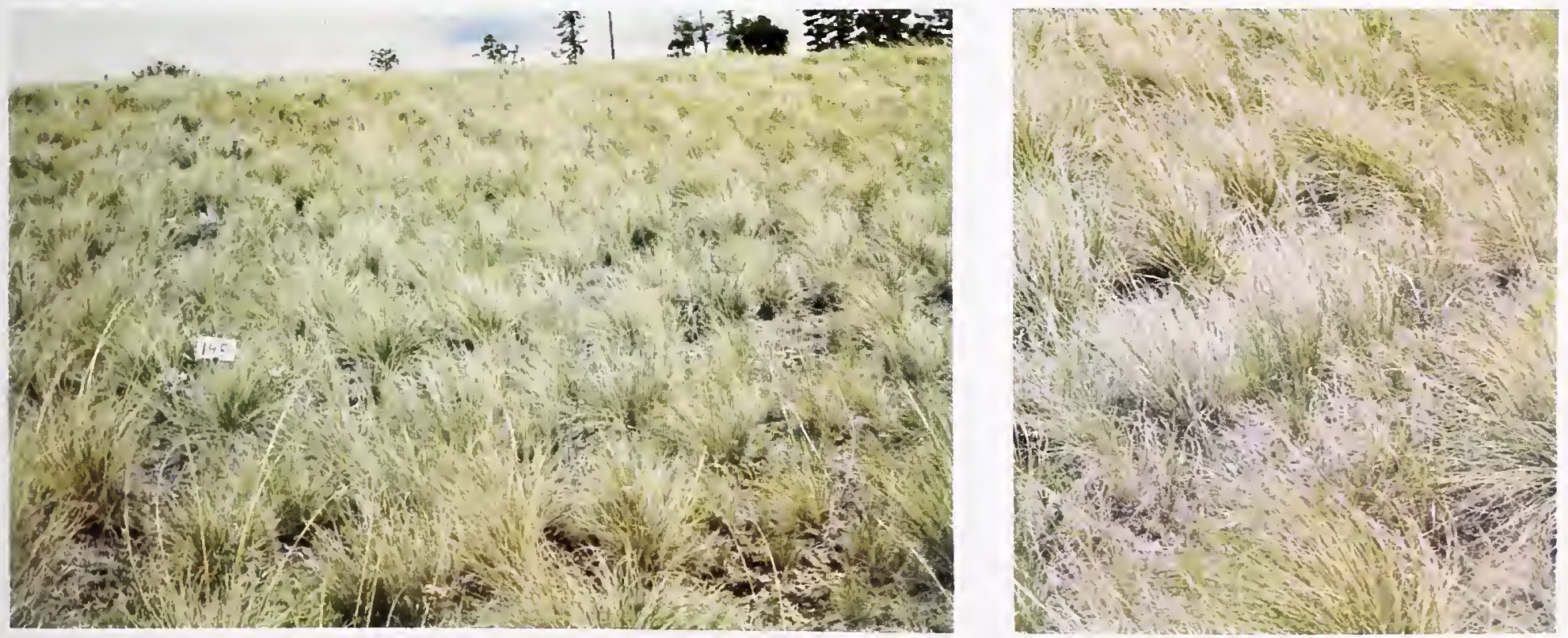

Figure 6.--Festuca scabrelza/Agropyron spicatum h.t. on a southwest facing slope, 3,500 $\mathrm{ft}$ elevation, in the foothills west of Flathead Lake in northwestern Montana. 
The flora of this habitat type is more complex than any of the types discussed so far. In some stands more than 50 species were recorded on the $20 \times 20 \mathrm{~m}$ macroplot. Both graminoid and forb species are very numerous; shrubs, however, are scarce (appendix E3). Lupinus sericeus can be very prominent and productive, though it may not occur in all stands.

The Stipa comata phase (STCO) of the FESC/AGSP h.t. is characterized by the prevalence of Stipa comata, the greater abundance of Bouteloua gracilis, Artemisia frigida, and Liatris punctata, and lesser quantities of Poa sandbergii and Antennaria rosea than the remainder of the habitat type. Most of the stands in this phase were encountered east of the Divide.

Productivity.--This habitat type is more productive than any of the habitat types in the Agropyron spicatum or Stipa comata series. The range in productivity between stands within the type is not great; stands selected to span the range in productivity differed only about 35 percent. Variation between years attributable to weather is considerably greater--in one case more than 200 percent during a 3-year period. The differences in production between stands selected to represent the range in productivity within the habitat type in Montana, and a measure of variation between years are presented in table 5 .

Table 5.--Extremes in production and variability over a 3-year period in the Festuca scabrella/Agropyron spicatum habitat type

\begin{tabular}{lcccc}
\hline \multirow{2}{*}{ Growth form } & \multicolumn{2}{c}{ Stand 232 } & & Stand 87 \\
\cline { 2 - 5 } & Average & SEl & Average & SEl \\
\hline
\end{tabular}

- . . . . - Air-dry Zb/acre- . . . . .

\begin{tabular}{lrrrr} 
Graminoids & 792 & 94 & 792 & 194 \\
Forbs & 96 & 10 & 339 & 92 \\
Shrubs & 1 & 1 & 15 & 4 \\
\multicolumn{1}{r}{ Total } & & & & 289
\end{tabular}

${ }^{1}$ Standard error over a 3 -year period.

${ }^{2}$ Multiply by 1.12 for $\mathrm{kg} / \mathrm{ha}$.

McLean and Tisdale (1972) reported production for similar vegetation in British Columbia as 441 to $1,055 \mathrm{lb} / \mathrm{acre}(460$ to $1,182 \mathrm{~kg} / \mathrm{ha})$ for good to excellent range condition. Under poor range condition they found that annual production was reduced by half.

Grasses are by far the most productive class of vegetation in this type, unless the vegetation is severely altered by overgrazing. Such good to excellent forage species as Festuca scabrella, Agropyron spicatum, Festuca idahoensis, and Koeleria cristata (appendix F) are normally abundant (appendix E3). As a class, the graminoids make up between 65 and 90 percent of the total biomass. The forbs constitute from about 10 to 25 percent, and the shrubs seldom exceed 5 percent of the total biomass. Very few species of shrubs occur in this type. On the other hand, a large variety of forbs may be present despite their minor role in overall productivity. The most consistently abundant plants other than grasses are such relatively unpalatable species as Artemisia frigida, Achillea millefolium, Lupinus sericeus, Antennaria rosea, and Cerastium arvense. The Stipa comata phase can be expected to have greater quantities of Artemisia frigida, Stipa comata, Allium cernuum, and Liatris punctata, and less Poa sanabergii, Antenneria rosea, Lupinus sericeus, and Cerastium arvense than the remainder of the type. 
Changes with grazing.--Festuca scabrella, the principal forage producer in this habitat type, is fairly sensitive to abusive grazing by cattle and horses. Consequently, it is the primary "decreaser" species. On range heavily overgrazed for many years, Festuca scabrella plants often are changed from robust tussocks to small weak shoots inconspicuous among the other grasses and forbs. Sizable differences in canopy cover between lightly and heavily grazed stands were apparent for several important species within the Festuca scabrella series, yet these differences lacked consistency. Agropron spicatum increased as well as decreased significantly on paired stands within this series (appendix G3) irrespective of habitat type. The literature supports this finding; Agropyron spicatum was shown as a decreaser in four references and as an increaser in three references for studies subsequently identified as related to the Festuca scabrella series. The same sort of variable reaction to grazing can be ascribed to Festuca idahoensis, which was shown as an increaser in five literature references and as a decreaser in two. Our stand data support this varied behavior irrespective of habitat type within the Festuca scabrella series. The status of Achillea millefolium was unclear from our data; the literature, however, suggests strongly that it should be considered an increaser. The principal species that increase with overgrazing in this habitat type are Artemisia frigida, Antennaria rosea, Cerastium arvense, and Chrysopsis villosa.

The following categorization of species reactions to overgrazing in the Festuca scabrezla series was developed from our differentially grazed communities and from our survey of literature: 
Agropyron canium Agropyron dasystachyum Carex vallicola Erigonum umbellatum Erigeron subtrinervis Festuca scabrella Liatris punctata Stipa michardsonii
Achillea millefolium

Anemone patens

Antennaria dimorpha

Antennaria rosea

Antennaria umbrinezla

Arenaria congestis

Amica fulgens

Artemisia frigida

Artemisia tridentata

Artemisia Zudoviciana

Aster campestris

Aster falcatus

Astragalus miser

Bouteloua gracilis

Carex filifolia

Carex pennsyzuanica

Cerastium arvense

Chrysopsia villosa

Comandra umbellata

Chrysothamnus nauseosus

Danthonia intermedia

Danthonia parmi

Danthonia unispicata

Erigeron compositus

Gaura coccinea

Geum triflorum

Gutierrezia sarothrae

Helictotrichon hookeri

Huechera spp.

Juniperus horizontalis

Juncus balticus

Koeleria cristata

Muhlenbergia cuspidata

Poa sandbergii

Potentizza fruticosa

Phlox albomarginata

Phlox hoodii

Sphaeralcea coccinea

Solidago missouriensis

Stipa comata

Stipa occidentalis

Stipa spartea
Bromus tectorm

Centaurea maculosa

Cirsium vulgare

Poa pratensis

Taraxicum officinale

Tragopogon dubius

Class of livestock grazing the vegetation influences changes in composition. Since sheep find forbs more palatable than do cattle, such species as Balsamorhiza sagittata, Vicia americana, and Geranium viscosissimum are more likely to decline on overgrazed sheep range than on overgrazed cattle range.

Range management.--Although the FESC/AGSP h.t. is suitable for use by all classes of livestock, the predominance of robust tussock grasses favors use by cattle and horses. Tisdale and others (1954) and McLean and Marchand (1968) recommend a late spring and early fall season of use for range of this type. 
Festuca scabrelza, the major forage producer on good condition ranges in this type, is very sensitive to grazing. Johnson and MacDonald (1967) suggest that maintenance of Festuca scabrella-dominated areas in climax or excellent condition may be impossible if grazing is permitted. This is attributed to the erect, readily accessible growth and highly palatable nature of the plant. Campbell and others (1962) recommend a grazing intensity for Festuca scabrelza prairie that will leave 40 to 50 percent carryover of the current year's growth and 20 percent of the seed stalks in order to maintain plant vigor. Even this may be too heavy, for Johnston (1961) found that 1ight grazing causes Festuca scabrella to decline somewhat.

A deferred or rest-rotation system of grazing (Hormay and Talbot 1961) may be beneficial for ranges of this type. However, McLean and Tisdale (1972) found that even under complete protection improvement from poor to excellent condition usually took 30 years. More time was required to go from poor to fair condition than from fair to good condition. They found that Agropyron spicatum recovered much more rapidly than Festuca scabrella. Since complete protection for such long periods of time is usually not economically acceptable management, they suggest grazing moderately in the fall or winter, when the plants are least susceptible, as a means of restoring depleted ranges.

Water development, fencing, and proper salting are methods for obtaining better distribution of livestock and more uniform use of the forage.

Noted elsewhere.--Similar vegetation in southern British Columbia has been described by Tisdale (1947) as the Agropyron-Festuca zone, and by Looman (1969) as the Festuca scabrella/Agropyron spicatum alliance. Looman indicates that this type generally is found below 4,000 ft $(1,200 \mathrm{~m})$ elevation in British Columbia. Ross and others (1973) list six stands of near-pristine vegetation in the foothill and Rocky Mountain areas of Montana that can be classified as EESC/AGSP h.t. Most of these occurred on loamy soils in the 15 - to 19 -in $(38-$ to $48-\mathrm{cm})$ precipitation zone.

\title{
Festuca scabrella/Festuca idahoensis h.t.
}

\author{
(FESC/EEID h.t.)
}

Distribution and environment.--The FESC/FEID h.t. occurs on mountain slopes on both sides of the Continental Divide, primarily north of $46^{\circ}$ latitude. The type extends to slightly higher elevations, 3,000 to 7,000 ft $(900$ to 2,100 m), and is found on sites more mesic than those occupied by the FESC/AGSP h.t. The type can occur on any exposure, but is generally confined to slopes less than 30 percent. This habitat type probably occurs primarily within the 20 - to 30 -in $(50-$ to $75-\mathrm{cm})$ precipitation zone.

The FESC/FEID h.t. can be found on a wide variety of soil parent materials, ranging from granitics to mixed glacial tills. Soils from three representative examples of this habitat type were classified as either Argic or Calcic Pachic Cryborolls. All were loamy and of ustic moisture and cryic temperature regimens (Níunn and others 1978). Solum depths ranged from 16 to 35 in (41 to $90 \mathrm{~cm}$ ), with a 9- to 14 -in (23- to $30-\mathrm{cm}$ ) A horizon (appendix C2). Solum reaction varied from slightly acid to neutra1, with free calcium carbonates not encountered until at least the 22 -in $(57-\mathrm{cm})$ depth. Usually very little bare soil or rock is exposed within this habitat type unless the vegetation is badly depleted (appendix D).

Vegetative composition.--Despite the great mixture of species within the FESC/FEID h.t., the vegetation is usually dominated by the two fescues, Festuca scabrella and Festuca idahoensis (fig. 7). In contrast to the EESC/AGSP h.t., Agropyron spicatum and shrubs are less conspicuous and may be absent; canopy cover of Festuca scabrelta 
tends to be greater; and Danthonia intermedia, Stipa occidentalis, and Carex spp. are more prevalent. Species diversity is also greater with a generally higher proportion of such forbs as Geum triflomm, Galium boreale, and Campanula rotundifolia (appendix E3). Koeleria cristata is a consistently occurring grass. Lupinus sericeus can be a dominant forb in this type, though it does not occur in all stands.
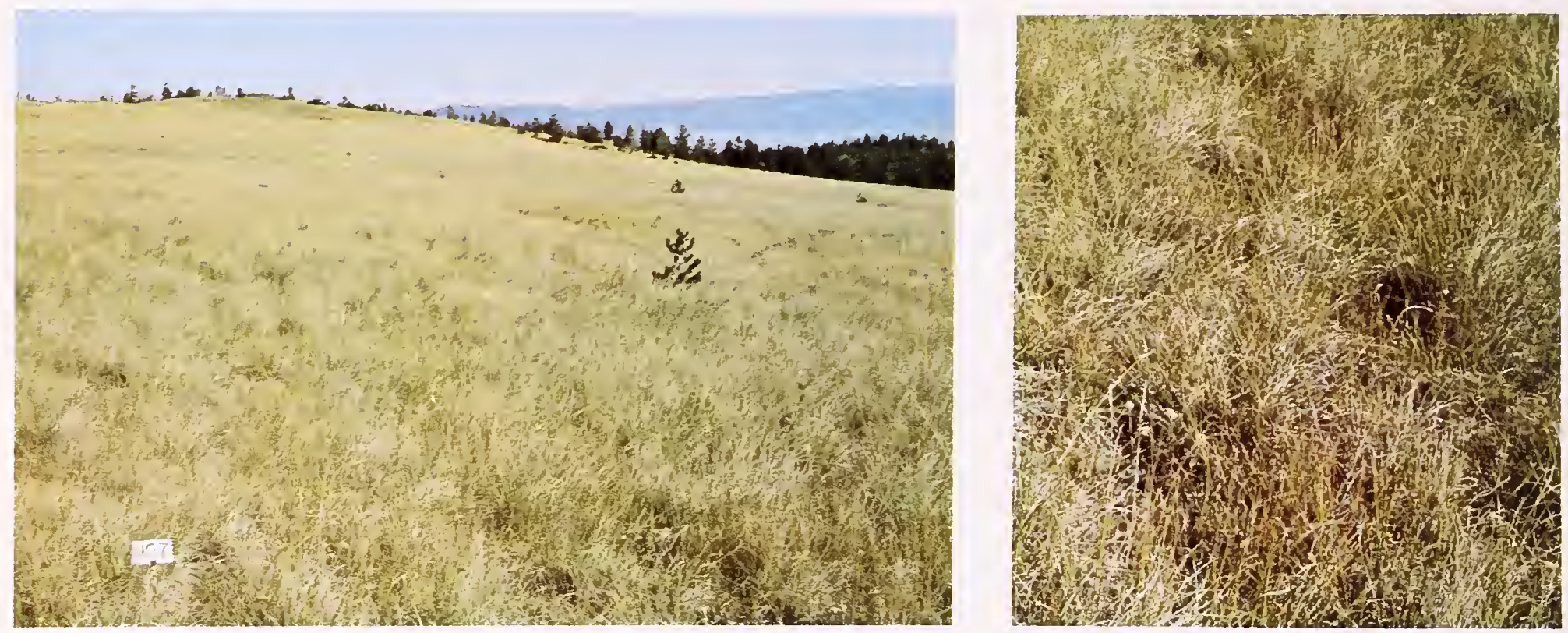

Figure 7.--Festuca scabrella/Festuca idahoensis h.t at 6,400 ft elevation near McDonald Pass west of Helena, Montana.

The Geranium viscosissimum phase (GEVI) is characterized by the presence and often abundance of Geranium viscosissimum and Potentilla gracilis. Stipa occidentalis and Agropyron spicatum are also generally more abundant here than in the remainder of the habitat type. Some of these more moist sites are marked by the conspicuous presence of Stipa michardsonii and substantial amounts of Carex filifolia and Danthonia intermedia. These have been designated the Stipa pichardsonii phase (STRI). In most other respects, this phase is similar to the Geranium viscosissimum phase.

Danthonia parryi has been observed occasionally as a codominant with Festuca scabrelza in northern Montana east of the Divide. Since species composition does not otherwise differ appreciably from the rest of the habitat type, a separate delineation did not appear appropriate.

Productivity.--We consider the EESC/FEID h.t. to be potentially one of the most productive upland forage types for cattle in western Montana. It produces at least onehalf ton of air-dry vegetation per acre $(1,120 \mathrm{~kg} / \mathrm{ha})$, most of which consists of palatable grasses. Differences between stands sampled for productivity did not exceed 45 percent. For the same stands, yearly differences between years attributable to weather amounted to as much as 100 percent. The data in table 6 represent the extremes in productivity of western Montana stands selected to sample this difference, and a measure of yearly variability in production due to weather. 
Table 6.--Extremes in production and variability over a 3-year period in the Festuca scabrella/Festuca idahoensis habitat type

\begin{tabular}{|c|c|c|c|c|}
\hline \multirow[b]{2}{*}{ Growth form } & \multicolumn{2}{|c|}{ Stand 304} & \multicolumn{2}{|c|}{ Stand 308} \\
\hline & Average & $\overline{\mathrm{SE}} \mathrm{l}$ & Average & SEl \\
\hline & $-\cdots$ & $-A i r$ & $e^{2}--$ & - \\
\hline Graminoids & 833 & 5 & 1,510 & 310 \\
\hline Forbs & 292 & 105 & 121 & 43 \\
\hline Shrubs & 1 & 1 & 0 & -- \\
\hline Total & 1,125 & 110 & 1,631 & 353 \\
\hline
\end{tabular}

${ }^{1}$ Standard error over a 3-year period.

2Multiply by 1.12 for $\mathrm{kg} / \mathrm{ha}$.

Data from Alberta (Johnston 1961), British Columbia (McLean and Marchand 1968), and Saskatchewan (Campbell and others 1962) suggest a wide range of productivity for Canadian vegetation similar to this habitat type. This variation is probably attributable to both environmental differences and to range condition. The range in herbage production, summarized by condition class, for this Canadian vegetation is:

Condition class

Excellent

Good

Fair

Poor
Range in $\mathrm{Zb} /$ acre

426 to 2,278
412 to 1,866
420 to 1,339
368 to 854

426 to 2,278

368 to 854

Based on our productivity studies in Montana, 70 to 90 percent of the total biomass for this habitat type is composed of graminoids. The remainder is forbs; shrubs are only incidental. Between 30 and 85 percent of the biomass consists of Festuca scabrezla. The other generally important forage species is Festuca idahoensis. Some fairly important producers in the Geranium viscosissimum phase of this habitat type are Agropyron spicatum, Stipa occidentalis, and Geranium viscosissimum; and in the Stipa richardsonii phase are Carex filifolia, Danthonia intermedia, and Stipa richardsonii.

A wide variety of other graminoids and forbs may also occur in this habitat type. Achillea millefolium, Arenaria congesta, Cerastium arvense, Geum triflorum, and Potentilla gracizis, all species with low palatability, are usually the most abundant forbs.

Changes with grazing.--A general listing of the reaction of plants to grazing in the Festuca scabrelza series is given in the description for the FESC/AGSP $h . t$. Festuca scabrella is the major species that declines with heavy cattle or horse use. We found that Festuca idahoensis declines in some instances of heavy grazing, but more often than not it increases. Characteristically, lightly grazed stands in this type are dominated by Festuca scabrelza, and heavily overgrazed stands are dominated by Festuca idahoensis. Other principal species that increase are Koeleria cristata, Carex filifolia, Geum triflorum, and various species of Danthonia. Very heavy use, particularly by sheep, may reduce the amount of such species as Geum triflorum and Geranium viscosissimum that tend to increase under less intensive grazing. This reaction is illustrated by the data for stands 241 and 242 in appendix G3.

Range management.--Grazing in this type can take place from late spring until early fall at the lower elevations. At the higher elevations west of the Continental Divide and on most of the type occurring east of the Divide, grazing may be confined to the summer months. The relative abundance of both grasses and forbs, particularly in the Geranium viscosissimum phase, make this habitat type well suited to all classes of livestock. 
Cattle grazing in this series should be keyed primarily to the reaction of Festuca scabrelza. Not only is it usually the major forage producer but it is highly sensitive to grazing as well. Sheep grazing should be keyed to the reaction of such important forbs as Geranium viscosissimum. Even light continuous summer grazing can cause changes in vegetation composition. Johnston (1961) found that light grazing by cattle in this type favored Danthonia parryi to the detriment of Festuca scabrezla. Light grazing resulted in greater diversity of plant species, greater total basal area, and a greater amount of root material than in an ungrazed area. Campbell and others (1962) found that heavy cattle grazing during the summer in this type of vegetation in Canada severely reduced Festuca scabrella and increased shrubby and weedy species; even moderate grazing, 1-1/2 acres (0.6 ha) per cow-calf month, reduced Festuca scabrella about one-third below that of light grazing, but did not appreciably affect Festuca idahoensis. In their study 2 acres $(0.8$ ha) per cow-calf month summer long was considered light grazing.

Deferred-rotation and rest-rotation systems of grazing may be used to advantage in the Festuca scabrella series. Rest-rotation appears best suited for ranges with adverse topographic conditions, as is often the case for the FESC/FEID h.t. However, rest-rotation may not be as desirable as deferred rotation for improving density of Festuca scabrelza.

Fencing, water development, and salting can often be used to advantage in this habitat type for obtaining better livestock distribution and more uniform forage utilization.

Noted elsewhere.--Ross and others (1973) list 16 stands of near-pristine vegetation in the Rocky Mountain and foothill areas of Montana that can be classified as being in the FESC/FEID h.t. Most of these occur in the 15- to 19-in (38- to 48- cm) precipitation zone on loamy or gravelly loam soils. Similar vegetation in western Alberta has been described by Stringer (1973) as the Festuca-Danthonia prairie. Looman (1969) described similar vegetation that occurs on warm slopes in the southern foothills of the Canadian Rocky Mountains as the Festuca scabrella/Danthonia intermedia association.

\title{
Festuca idahoensis/Agropyron smithii h.t.
}

\author{
(FEID/AGSM h.t.)
}

Distribution and environment.--In Montana this habitat type is confined almost exclusively to areas east of the Continental Divide, but it ranges from the Canadian border to Wyoming. It occurs on relatively gentle slopes (less than 15 percent) where the plains join the mountains. The type has been found as high as $8,000 \mathrm{ft}(2,400 \mathrm{~m})$ in elevation, but most of the time it will be found between 4,000 and 6,000 ft $(1,200$ and $1,800 \mathrm{~m})$. Soils are usually moderately deep and of sedimentary origin. The soil is usually well covered by vegetation. In the stands we sampled, the amount of bare soil ranged from 1 to 8 percent and the amount of soil covered by rock ranged from 1 to 18 percent.

Vegetative composition.--All habitat types within the Festuca idahoensis series are characterized as grasslands where Festuca idahoensis is one of the dominant graminoids and where Festuca scabre 2 la, if present at all, is a very minor part of the community. The FEID/AGSM h.t. is differentiated from the other habitat types in the series by the presence and often abundance of rhizomatous wheatgrasses (Agropyron smithii and/or Agropyron dasystachyum), and the absence or scarcity (less than 5 percent canopy 
cover) of Agropyron spicatum (fig 8). Grasses are usually far more abundant than either forbs or shrubs. Poa cusickii is often conspicuous and is associated with or replaces Poa sandbergii. Koeleria cristata is also a prominent grass in this habitat type. Phlox hoodii, Gaillardia aristata, Antennaria rosea, and Achillea millefolium are usually the most prominent forbs (appendix E4). Shrubs, if present, are usually scattered; Artemisia frigida is the only shrub with high constancy.
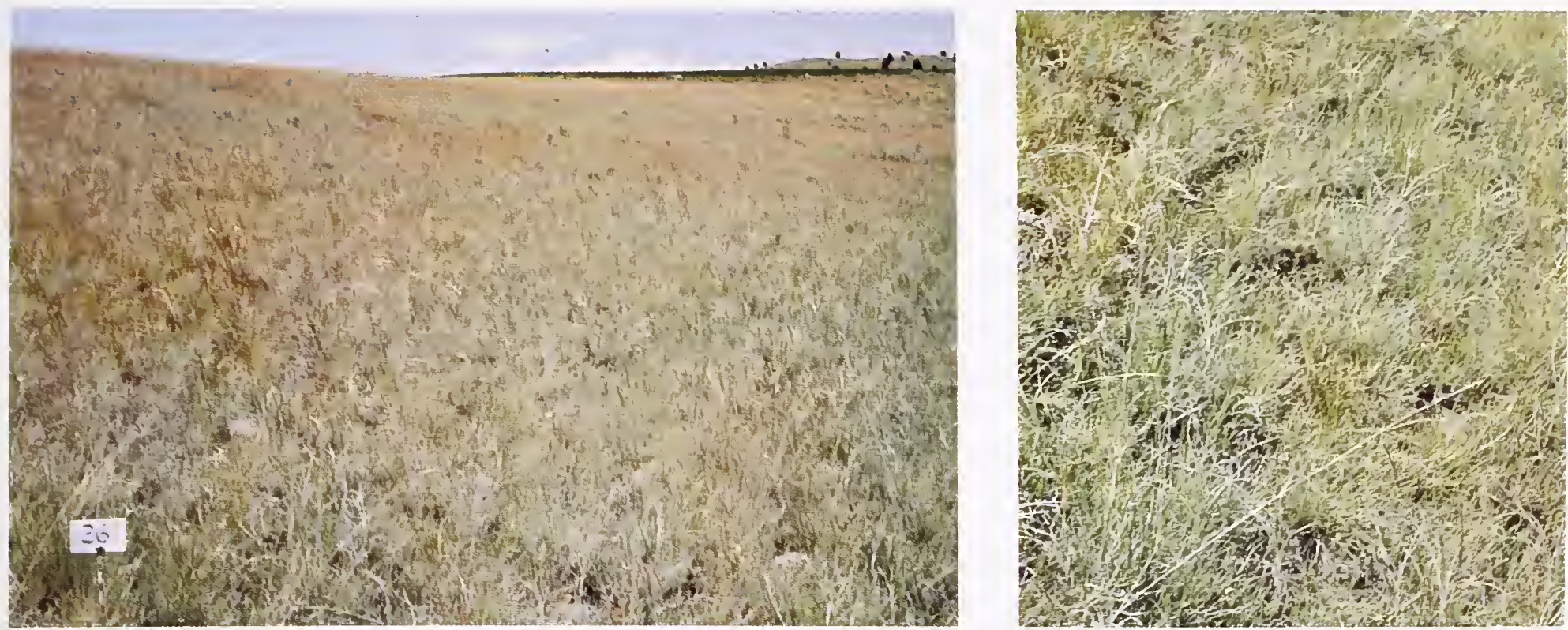

Figure 8.--Festuca idahoensis/Agropyron smithii h.t. on rolling foothills at 5,100 ft elevation west of Bozeman in southwestern Montana.

Productivity.--We found that stands selected to span the range of site potential within the EEID/AGSM h.t. exhibited an 80 percent difference in total production.

Even greater variation in annual production can be caused by yearly weather differences. Over a period of three consecutive years, one stand produced 110 percent more herbage in the high year than in the low year. The extremes in production between the stands we sampled in Montana and a measure of the variation between years are presented in table 7 .

Table 7.--Extremes in production and variability over a 3-year period in the Festuca idahoensis/Agropyron smithii habitat type

\begin{tabular}{|c|c|c|c|c|}
\hline \multirow[b]{2}{*}{ Growth form } & \multicolumn{2}{|c|}{ Stand 217} & \multicolumn{2}{|c|}{ Stand 171} \\
\hline & Average & $\mathrm{SE}^{1}$ & Average & SEI \\
\hline & $--\cdot-$ & $-A i r$ & $x c r e^{2}-$ & \\
\hline Graminoids & 354 & 24 & 1,118 & 61 \\
\hline Forbs & 344 & 107 & 168 & 77 \\
\hline Shrubs & 21 & 9 & 6 & 6 \\
\hline Total & 719 & 108 & 1,292 & 131 \\
\hline
\end{tabular}

${ }^{1}$ Standard error over a 3 -year period.

${ }^{2}$ Multiply by 1.12 for $\mathrm{kg} / \mathrm{ha}$.

Grasses usually comprise about 80 percent of the total production in this type. However, as shown in the data for stand 217 (table 7), forbs can be abundant, although this is an exception. Shrubs are generally only a minor component. 
Festuca idahoensis, Agropyron smithii, and Agropyron dasystachyum are the primary forage producers. Usually Eestuca idahoensis makes up 30 to 60 percent of the total biomass and the rhizomatous wheatgrasses make up from 10 to 60 percent. KoeZeria cristata, Poa cusickii, and Poa sandbergii, also desirable forage species, occur in lesser quantities. Forbs and shrubs usually consist of such low-value forage species as Phlox hoodii, Gaillardia aristata, Achillea millefolium, and Artemisia frigida.

Changes with grazing.--Festuca idahoensis is the principal forage species that declines with overgrazing in this habitat type. Although Agropyron smithii is very palatable, neither it nor Agropyron dasystachyum apparently respond consistently to grazing--in some cases they decrease and in others they increase. The principal species that increase are Artemisia frigida, Poa sandbergii, Poa cusickii, and possibly Koeleria cristata. A generalized listing of the response of species in the Festuca idahoensis series is given in the discussion of the FEID/AGSP h.t.

Range management.--The fairly low elevational occurrence of much of this habitat type makes it suitable for grazing in either the spring, summer, or fall. However, repeated heavy use in early summer when carbohydrate reserves in the grasses are likely to be at a low point may be very harmful to the vegetation. The higher elevation areas can usually be used only in the summer. The type is best suited for use by cattle and horses because of the predominantly graminoid vegetation.

Unfortunately, management information that can be identified specifically to this and many of our other minor habitat types is lacking in the literature. Consequently, management guides must be inferred from the known requirements and reactions of the major species as they occur in other better-understood vegetation types. Festuca idahoensis, the rhizomatous wheatgrasses (Agropyron smithii and Agropyron dasystachyum) and the Poa spp. are the major forage producers in the FEID/AGSM h.t. Information discussed in the FEID/AGSM h.t. and AGSP/AGSM h.t. sections regarding management of these species may be applicable in this habitat type as well.

\title{
Festuca idahoensis/Agropyron spicatum h.t.
}

\author{
(FEID/AGSP h.t.)
}

Distribution and environment.--This is perhaps the most frequently encountered mountain grassland habitat type in southwestern Montana. Although it occurs throughout the western part of the State, it is particularly prevalent on intermediate elevation mountain slopes south of $46^{\circ}$ latitude. The type can be found at elevations ranging from 4,500 to $7,500 \mathrm{ft}(1,400$ to $2,300 \mathrm{~m})$. It tends to occur more on northerly exposures at the lower elevations and on southerly exposures at the higher elevations. The Stipa occidentalis phase (STOC) is usually found at the higher elevations. Percent slope is not restrictive. This is a moderately mesic grassland type that probably occurs primarily within the 14 - to $20-$ in $(35-$ to $50-\mathrm{cm}$ ) precipitation zone.

Soils from four representative stands of the FEID/AGSP h.t. were either Typic Haploborol1, or Typic or Calcic Cryoborol1; all were of ustic moisture and cryic temperature regimens (Munn and others 1978). The soils had an 8- to 11-in (21- to 28$\mathrm{cm})$ A horizon, and a 17 - to 35 -in $(44-$ to $89-\mathrm{cm})$ solum depth. The solum was neutral to slightly alkaline. Free calcium carbonate was encountered at depths ranging from 8 to 35 in (21 to $90 \mathrm{~cm}$ ). This habitat type occurs on a wide variety of soil parent materials. The amount of soil surface covered by rock ranged from 0 to 40 percent, whereas the amount of bare soil ranged from 0 to 25 percent (appendix D). 
Vegetative composition.--Agropyron spicatum is always present and more abundant than any of the rhizomatous wheatgrasses, and usually is an obvious codominant with Festuca idahoensis (fig. 9). Although a wide variety of other graminoids can occur in this type, Koeleria cristata, Poa sandbergii, and either Stipa comata or Stipa occidentalis are the only ones that are usually present and form substantial canopy cover. The amount of forbs is highly variable, ranging from 10 to 60 percent canopy cover. Achillea millefolium, Antennaria rosea, Arenaria congesta, and possibly Phlox hoodii are the forbs that occur most consistently (appendix E4). Lupinus sericeus, if present, can form a major part of the plant community. Medium shrubs such as Chrysothamnus viscidiflorus and Artemisia tridentata may occasionally be present, but they are never abundant unless the type has been severely disturbed.
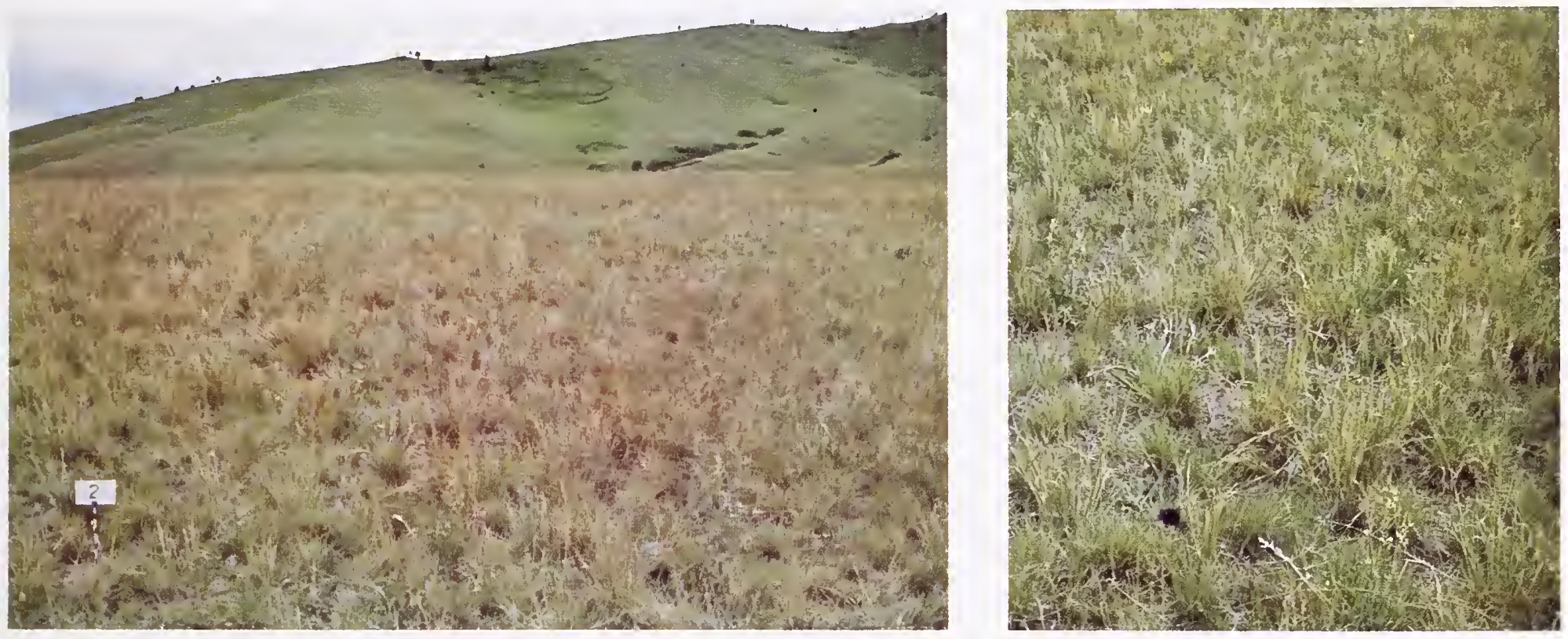

Figure 9.--Festuca idahoensis/Agropyron spicatum h.t. on a north west facing clope at $5,200 \mathrm{ft}$ elevation in the foothills west of Bozeman. This is one of the most frequently encountered types in southwestern Montana.

The more moist Stipa occidentalis phase is characterized by conditions where Stipa occidentalis is more freauent and abundant than Stipa comata. Such species as Agropyron caninum, Danthonia intermedia, Geum triflorum, Agoseris glauca, Companula rotundifolia, Cerastium arvense, Gaillardia aristata, and Galium boreale are more likely to be a prominent part of the vegetation in this phase than in the remainder of the habitat type.

Productivity.--We sampled four different stands over a 3-year period to evaluate the productivity potential of the FEID/AGSP h.t. in western Montana. These stands were selected to span the range in site potential within the type. The best site produced almost twice as much biomass as the poorest site. Production appeared to be greater on the northerly exposures, suggesting that lower insolation and greater moisture availability may be partly responsible for differences in site potential. Production of a stand varied as much as 56 percent over the 3 -year period because of yearly weather differences. The extremes in production between the stands we sampled in this type and the standard error of differences in production between years are presented in table 8 . 
Table 8.--Extremes in production and variability over a 3-year period in the Festuca idahoensis/Agropyron spicatum habitat type

\begin{tabular}{|c|c|c|c|c|}
\hline \multirow[b]{2}{*}{ Growth form } & \multicolumn{2}{|c|}{ Stand 27} & \multicolumn{2}{|c|}{ Stand 28} \\
\hline & Average & SE 1 & Average & SE 1 \\
\hline & --- & Air- & $r e^{2}-$ & \\
\hline Graminoids & 271 & 21 & 465 & 91 \\
\hline Forbs & 385 & 52 & 827 & 107 \\
\hline Shrubs & 1 & 1 & 0 & -- \\
\hline Total & 655 & 73 & 1,293 & 173 \\
\hline
\end{tabular}

${ }^{1}$ Standard error over a 3 -year period.

${ }^{2}$ Multiply by 1.12 for $\mathrm{kg} / \mathrm{ha}$.

Daubenmire (1970) found that protected vegetation of a similar type in eastern Washington produced approximately $1,300 \mathrm{lb} / \mathrm{acre}(1,450 \mathrm{~kg} / \mathrm{ha})$ of which 60 percent was perennial grasses. Vogel and Van Dyne (1966) found vegetation of this type in southwestern Montana producing $660 \mathrm{lb} / \mathrm{acre}(770 \mathrm{~kg} / \mathrm{ha})$ on a protected site and $590 \mathrm{lb} / \mathrm{acre}$ $(660 \mathrm{~kg} / \mathrm{ha})$ on a grazed site. In their study approximately 70 percent was graminoids. In other studies in southwestern Montana, Mueggler (1972b) found that a stand at the drier end of the EEID/AGSP h.t. produced between 605 and $818 \mathrm{lb} / \mathrm{acre}(678$ and $916 \mathrm{~kg} / \mathrm{ha})$ over a 5-year period; about 60 percent of this production consisted of graminoids. $\dot{A}$ stand on a more mesic northerly exposure within this habitat type produced from 724 to $1,599 \mathrm{lb} /$ acre (810 to $1,790 \mathrm{~kg} / \mathrm{ha}$ ) over a 5-year period, of which only 26 percent was graminoids. Mueggler (1972b) found that herbage production fluctuated considerably more between years on the more productive northerly aspects than on the southerly aspects.

The proportion of forbs to graminoids differs appreciably between stands within this habitat type. Overal1, however, forbs form a greater proportion of the vegetation in the FEID/AGSP h.t. than in any of the previously described types. They are especial1y abundant within the relatively mesic Stipa occidentalis phase of this habitat type.

Graminoid production in our stands ranged between 35 and 70 percent of the vegetation. Most of these grasses are considered good forage species. Between 30 and 65 percent of the total production consisted of forbs, most of which are fairly low in palatability. The proportion of grasses to forbs in a stand did not change more than about 25 percent as a result of yearly weather differences. In none of the four stands sampled did shrub production exceed 5 percent of the total biomass.

Festuca idahoensis and Agropyron spicatum are the two species that produce the most forage within this habitat type. Together they usually comprise between 30 and 65 percent of the total air-dry production. Other important forage producers in the Stipa occidentalis phase are Carex petasata and Stipa occidentalis. The most abundant forbs, Achillea millefolium, Phlox hoodii, Cerastium arvense, Lupinus sericeus, Geum triflorum, and Antennaria rosea are generally poor forage species.

Changes with grazing.--Agropyron spicatum and Festuca idahoensis are the principal species that decrease with heavy grazing in this habitat type. In some instances, Festuca idahoensis may increase with the reduction of Agropyron spicatum, but it will eventually decrease with continued heavy use. The principal species that usually increase are Artemisia frigida, Poa sandbergii, Cerastium arvense, and Phlox hoodii. The response of Iupinus spp. and Koeleria cristata are variable and defy general categorization. 
Summarized below is a listing of species in the Festuca idahoensis series according to general response to grazing. This list was developed from our data on differentially grazed paired stands and from information contained in literature.

\section{Decreasers}

Agoseris grauca Agropyron caninum Agropyron spicatum Aster integrifolius Bromus marginatus Crepis spp. Erigeron caespitosus Festuca idahoensis Geranium viscosissimum Hesperochloa kingii Lupinus spp. Poa ampla Poa interior Potentilza gracilis Stipa viridula Vicia americana

\section{Increasers}

Achillea millefolium

Amica fulgens

Artemisia frigida

Campanula rotundifolia

Carex petasata

Carex stenophyzla.

Cerastium arvense

chrysopsis villosa.

Chrysothamus nauseosus

Danthonia intermedia

Danthonia unispicata

Erigeron compositus

Erigeron filifolius

Gaura coccinea

Geum triflomm

Helictotrichon hookeri

Hymenoxys acaulis

Gutierreaia sarothrae

Koeleria cristata.

Pendicularis contorta

Phlox hoodii

Poo cusickii

Poa sandbergii

Potentilla diversifolia

solidago missoumiensis

Stipa comata

Stipa lettermanii

Stipa occidentalis
Invaders

Bromus tectorum

C'entaurea maculosa

Cirsium vulgare

Poa pratensis

Taraxicum officinale

Tragopogan dubius

The literature suggests that Carex obtusata, Antennaria rosea, Astragalus miser, and Phlox miltiflora increase with grazing in this series, but our data (appendix G4) indicate the opposite; therefore, we did not assign these four species to either category. Both Chrysothamus viscidifloms and Tetradymia canescens decreased significantly on the grazed member of paired stands 112 and 113 , but this is attributed to elk and deer winter browsing. If anything, these two shrubs probably increase under summer grazing by livestock. Prolonged heavy use of the EEID/AGSP h.t. may also encourage a great increase in the abundance of Artemisia tridentata. Bromus tectomum is the principal annual species that invades this type.

Range management.--Although the EEID/AGSP h.t. is perhaps best suited for cattle production, the abundance of forbs, particularly in the Stipa occidentalis phase, makes it acceptable sheep range. At lower elevations the type can be used by livestock in the spring, summer, and fall. Use is usually not possible at midelevations until early summer and can continue well into the fall. Use at the highest elevations is generally confined to midsummer and early fall because of the lag in plant development and likelihood of late spring and early fall snows. 
The type is widely used by big game animals. Consequently, the resource manager should be alert to potential conflicts between wildlife and livestock. The type is used by elk and deer at the lower elevations as winter range, and by antelope yearround. For example, elk in the Elkhorn Mountains apparently spend all of their time from January through March in this type, subsisting on a diet of 75 percent dried grasses and 25 percent forbs (Stevens 1966). At intermediate elevations, the type is important spring-fall range, and at the highest elevations summer range for elk and deer. These wild ungulates commonly migrate upward in the spring following the snow line to graze avidly on fresh green herbage. Fall snow storms start the animals on their return migration to lower elevations where they winter. Stevens (1966) concluded that a potential conflict exists in this type between summer and fall use by cattle and fall-winter-spring use by elk. He also concluded that a potential conflict exists in summer use of the type by elk and sheep because of the high proportion of forbs in the summer diets of both. Certain sites at moderately high elevations are used by bighorn sheep and Rocky Mountain goats as winter range.

Proper use of the type under cattle grazing should be keyed primarily to the sensitivities of Agropyron spicatum, as discussed in management of the AGSP/BOGR h.t. The other principal forage grass, Festuca idahoensis, is not nearly as sensitive to abusive grazing because of its lower growth stature and lower palatability. Festuca idahoensis, however, is a valuable forage producer and deserves consideration in management. Its protein content, for example, apparently remains higher than that of Agropyron spicatum and other grasses during the latter part of the growing season (Skovlin 1967; Beath and Hamilton 1952; Pond and Smith 1971). Festuca idahoensis appears most sensitive to heavy defoliation at approximately the same stage of growth as Agropyron spicatum; that is, from flowering to seed ripening (Mueggler 1967). The calendar dates of the sensitive growth stages of these two important forage grasses coincide reasonably well (Mueggler 197,2b), which simplifies management.

The resource manager must remain aware of weather-induced variability in rate of plant development from year to year. During a 5-year period, Mueggler (1972b) found that the appearance of flower culms in Festuca idahoensis differed as much as 4 weeks and blooming differed as much as 1 week; appearance of flower stalks in Agropyron spicatum varied more than 2 weeks and blooming 1 week. During a 5-year period, Pond and Smith (1971) report almost a 4-week difference in the date when Festuca idahoensis in northern Wyoming reached the "heads showing" development stage. The time when these mountain grassland species reach given developmental stages also differs with topography. Hopkins' Bioclimatic Law (Hopkins 1938) suggests a 10-day lag in plant development for each $1,000 \mathrm{ft}(304 \mathrm{~m})$ elevational rise. Mueggler (1972b), however, found that in the Gravelly Range of southwestern Montana, Festuca idahoensis at 8,200 $\mathrm{ft}(2,500 \mathrm{~m})$ bloomed on the average 16 days later than it did at $7,100 \mathrm{ft}(2,160 \mathrm{~m})$. He also found that Festuca idahoensis bloomed an average 4 days later and Agropyron spicatum an average of 2 days later on northeasterly exposures than on southwesterly exposures.

The amount of use Agropyron spicatum and Festuca idahoensis can sustain without adversely affecting vigor is not easily generalized. It depends upon numerous considerations, the foremost ones being the time in the plant's development cycle when the use occurs, the type of grazing system used, and local site conditions. For example, Beetle and others (1961) found that although Festuca idahoensis could withstand moderate continuous grazing (40 to 45 percent utilization) on sedimentary soils, even light grazing reduced its vigor on granitic soils. The only reliable approach for determining proper use under any given situation and grazing system is to observe the reaction of the vegetation over a period of years. If the vigor of key forage species is being reduced, if young plants are not becoming established, if undesirable plants are increasing, and if soil disturbance is unacceptable, then either stocking rates or grazing systems should be altered. 
Once the vigor of the principal forage grasses is reduced, recovery may be slow. A].though ricrmay and Talbot (1961) indicate that Festuca idahoensis in northern California that had suffered a vigor loss equivalent to half its basal area recovered fully after 3 seasons of rest, a much longer period may be required in Montana. Mueggler (1975) found that although Festuca idahoensis of moderately low vigor in the FEID/AGSP h.t. required 3 years of rest to regain full vigor, those with even lower vigor produced only two-thirds as much herbage and two-thirds as many flower stalks as normal plants even after 5 years of rest. He also found that Agropyron spicatum is more sensitive to heavy use than Festuca idahoensis and recovers more slowly. He indicated that recovery of moderately low vigor Agropyron spicatum would require at least 6 years of rest, and very low vigor plants would require more than 8 years of rest.

As discussed in the AGSP/BOGR h.t. description, vigor of Agropyron spicatum can be assessed by comparing both numbers of flowering culms and maximum culm 1 engths between grazed and protected plants. Vigor determinations for Festuca idahoensis also depend upon comparison of grazed and protected plants because of yearly differences in plant attributes caused solely by weather. Evanko and Peterson (1955) and Pond (1960) suggested that leaf length, basal area, and herbage weight were of almost equal value in determining vigor of Festuca idahoensis. Hurd (1959) indicated that maximum leaf length alone was a reliable vigor index. Mueggler (1970) suggested that the number of flower stalks was the most sensitive indicator of vigor for this grass. He later concluded that maximum leaf length was more reliable and potentially useful, particularly when expressed in terms of differences in productivity by means of a regression equation (Mueggler 1975).

Judging from the literature, a rotation system of grazing may be of questionable value in a vegetation type where Festuca idahoensis is a major dominant. Smith and others (1967) found that rotation grazing failed to benefit this major forage species in the Big Horn Mountains of Wyoming. Pond and Smith (1971) suggest that where rotation and rotation-deferred grazing systems appear to have benefited the range, the improvements probably result from the additional fencing, water development, and sagebrush spraying that usually accompanies the change in grazing systems. Ratliff and Reppert (1974) found that in northern California moderate, continuous grazing permitted Festuca idahoensis to maintain its vigor; a rest-rotation system neither reduced nor improved the vigor of this grass, but may hold vigor at a higher level than does continuous grazing. Furthermore, they concluded that range managers cannot reliably key seed production into a rest-rotation system because of the strong relationship between high seed production and high spring precipitation. They recommend that to enhance establishment of new plants a pasture should be grazed only lightly until after seed ripening in those years when spring precipitation is good and flower stalks profuse; concentrating livestock on the pasture after seed ripening would then tend to trample the seed into the soil.

Fencing, water development, and proper salting contribute to better livestock distribution and greater uniformity of use in this type. Fertilization may also be an effective tool to improve livestock distribution as well as to increase forage production. In eastern Washington, production of Festuca idahoensis was quadrupled by application of $20 \mathrm{lb} / \mathrm{acre}(22 \mathrm{~kg} / \mathrm{ha}$ ) of $\mathrm{N}$ (Patterson and Youngman 1960). Although fertilization with $68 \mathrm{lb} /$ acre $(76 \mathrm{~kg} / \mathrm{ha}) \mathrm{N}$ in Wyoming did not significantly improve grass production, it did effectively increase utilization of a lightly used area for at least 2 years (Smith and Lang 1958).

Noted elsewhere.--Daubenmire (1970) described an Agropyron spicatum/Festuca idahoensis h.t. for eastern Washington that contains the same dominant grasses as the Montana EEID/AGSP h.t. but differs appreciably in secondary species. His type generally lacks such species as Artemisia frigida, Koeleria cristata, Antennaria rosea, Arenaria congesta, Phlox hoodii, and Agoseria glauca that are common in the Montana type. The Agropyron-Festuca community type described by Hall (1973) for Oregon and 
the Agropyron spicatum/Festuca idahoensis association described by Franklin and Dyrness (1969) for the Columbia Basin bear more resemblance to Daubenmire's AGSP/FEID h.t. than to our Montana type. McLean (1970) described a Festuca idahoensis/Eriogonum heracleoides type occurring in the Similkameen Valley of British Columbia that is somewhat similar to our FEID/AGSP h.t. except for its abundance of Eriogonum heracleoides and lack of Koeleria cristata, Phlox hoodii, and Antennaria rosea.

\section{Festuca idahoensis /Agropyron caninum h.t.}

(FEID/AGCA h.t.)

Distribution and environment.--The FEID/AGCA h.t. is found on moderate to high elevation mountain slopes primarily east of the Continental Divide and south of $47^{\circ}$ latitude. It commonly occurs on rather gentle slopes at elevations ranging from 6,500 to $8,600 \mathrm{ft}(2,000$ to $2,600 \mathrm{~m})$. This is a moderately mesic habitat type, which probably falls within the 18 - to $30-$ in $(45-$ to $75-\mathrm{cm})$ precipitation zone. However, the relatively high elevations create fairly low potential evapotranspiration and a short growing season (appendix C1). The Geranium viscosissimum phase (GEVI) of this habitat type is slightly more mesic and tends to occur on easterly and northerly exposures.

Soils from selected stands in the EEID/AGCA h.t. were classified as either Argic or Pachic Cryoborolls of ustic moisture and cryic temperature regimens (Munn and others 1978). The loamy-soil A horizons ranged from 9 to 22 in $(23$ to $56 \mathrm{~cm})$ thick, and the solums from 15 to 49 in $(38$ to $124 \mathrm{~cm}$ ). The soils were slightly acid (pH from 6.0 to 6.5 ) and free calcium carbonates occurred only at depths greater than 37 in $(95 \mathrm{~cm})$. Amount of bare soil surface averaged 4 percent and ranged as high as 13 percent for the 16 stands sampled in this habitat type (appendix D). The type was found on a wide variety of soil parent materials.

Vegetative composition.--Although the FEID/AGCA h.t. has a predominantly grass1 and aspect (fig. 10), it has a higher proportion of forbs (30 to 70 percent canopy cover) than most of the other western Montana habitat types. Festuca idahoensis is usually the dominant grass. Agropyron canium is consistently present and is the dominant wheatgrass. Other usually important graminoids in this type include Stipa occidentalis, Koeleria cristata, Danthonia intermedia, and Carex petasata (appendix E4). Usually abundant forbs include Geum triflomm, Potentilla gracilis, Achillea miliefolium, Agoseris glauca, Campanula rotundifolia, and Arenaria congesta. Shrubs are very scarce.

The more mesic Geranium viscosissimum phase is characterized by the abundance of Geranium viscosissimum and Potentizla gracilis, and the presence of either Bromus carinatus or Broms anomalous and Poa juncifolia. 

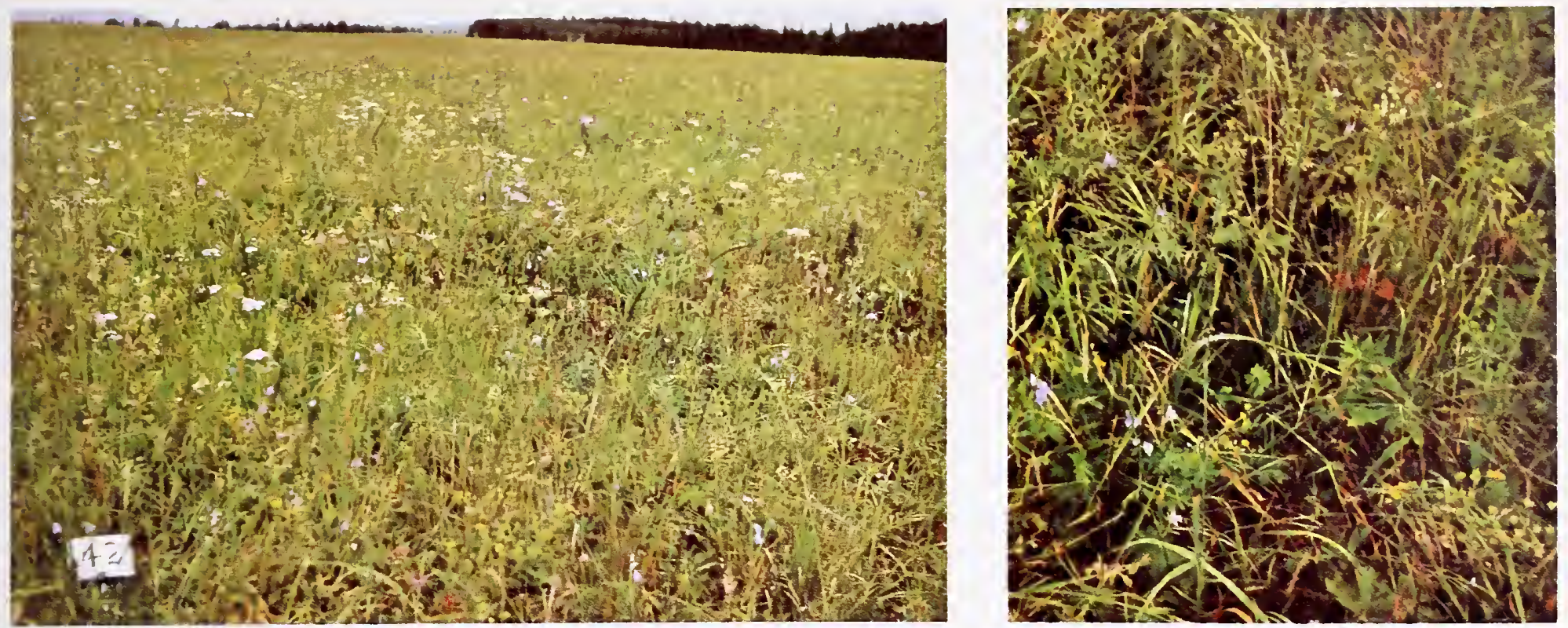

Figure 10.--Festuca idahoensis/Agropyron caninum h.t. occurring on deep loessal soils within the Cliff Lake Research Natural Area, 7,000 ft elevation, in Madison County, southwestern Montana.

Productivity.--This is one of the most productive grassland habitat types in southwestern Montana. Only the DECA/CAREX mountain meadows are likely to produce more. Three stands selected to span the range in productivity within the type differed as much as 30 percent in total production. During a 3-year period, however, one stand produced more than twice as much herbage in the high year as in the low year because of yearly weather differences. Generally, the Geranium viscosissimum phase produces more total plant biomass than the rest of the habitat type. Extremes in production between our stands, and the variability caused by weather are presented in table 9.

Table 9.--Extremes in production and variability over a 3-year period in the Festuca idahoenis/Agropyron caninum habitat type

\begin{tabular}{|c|c|c|c|c|}
\hline \multirow[b]{2}{*}{ Growth form } & \multicolumn{2}{|c|}{ Stand 125} & \multicolumn{2}{|c|}{ Stand 56} \\
\hline & Average & SEI & Average & $\mathrm{SEl}$ \\
\hline & --- & $-A i r$ & $\operatorname{cres}^{2}-\cdots$ & \\
\hline Graminoids & 368 & -- & 907 & 96 \\
\hline Forbs & 825 & -- & 765 & 88 \\
\hline Shrubs & 0 & -- & 0 & -- \\
\hline Total & 1,194 & -- & 1,672 & 137 \\
\hline
\end{tabular}

\footnotetext{
${ }^{1}$ Standard error over a 3 -year period.

2Multiply by 1.12 for $\mathrm{kg} / \mathrm{ha}$.
} 
Our production figures are somewhat lower than those obtained in other studies on this type of vegetation in Montana. For example, Branson and Lommasson (1958) recorded total air-dry weights of 2,100 and $2,300 \mathrm{lb} / \mathrm{acre}(2,350$ and $2,575 \mathrm{~kg} / \mathrm{ha})$ on two sites. Mueggler (1967) obtained total production figures varying from 1,615 to 2,622 1b/acre (1,809 to 2,937 kg/ha) over a 3-year period (1963 through 1965) on a luxuriant FEID/AGCA grassland. In the Big Horn Mountains of Wyoming, Hurd (1961) obtained total production figures ranging from 1,120 to $3,311 \mathrm{lb} / \mathrm{acre}(1,254$ to $3,708 \mathrm{~kg} / \mathrm{ha})$ in vegetation similar to this habitat type.

The proportion of graminoids in the stands we measured for production ranged from 30 to 60 percent. Generally, forbs formed a greater proportion of the total in those years when overall production was high than when it was low--or, forbs appeared more responsive than the grasses to a good growing year. Shrubs are rare. A wide variety of grasses and sedges, most of which are relatively good forage species, occur in this type. Seldom does a single species predominate. Ordinarily, Festuca idahoensis is the most abundant grass, but it seldom constitutes more than 20 percent of the total production. Other important forage species may be Bromus carinatus, Agropyron caninum, Koeleria cristata, and possibly Stipa occidentalis and Danthonia intermedia. A wide variety of forbs usually occur in this type. Most of these are considered lower in palatability than the grasses; thus, their contribution to usable forage is probably less than the amount suggested by their total biomass.

Changes with grazing.--Heavy grazing of the FEID/AGCA h.t. will result in a pronounced decrease of such forage producers as Agropyron caninum, Bromus carinatus, Bromus anomalus, and Festuca idahoensis. Possibly Geranium viscosissimum, Iupinus spp., and perhaps Potentilla gracilis will also decrease if heavily grazed by sheep. The species most likely to increase are Danthonia intermedia, Geum triflomm, Solidago missouriensis, Polygonum bistortoides, and Achillea millefolium. The carices, Carex petasata, Carex stenophylla, and Carex obtusata, also are likely to increase. Substantial increases in Artemisia tridentata ssp. vaseyana may occur in this habitat type if the type is continually abused. The principal invading species is Cirsium vulgare. A general listing of the reaction of species to grazing in the Festuca idahoensis series is given in the discussion for the FEID/AGSP h.t.

Range management.--The abundance and variety of forbs in the FEID/AGCA h.t., particularly in the Geranium viscosissimum phase, make it one of the better types for summer grazing by sheep. It is also suitable as summer cattle range because of the abundance of graminoids. Use is generally limited to midsummer because of the lateness in development of the vegetation at these higher elevations and the probability of late spring and early fall storms. Elk, deer, and even moose frequent the type throughout the summer. Consequently, local conflicts may exist in coordinating livestock and wildlife use.

Management of the type as cattle range should be keyed to the reaction of the major perennial forage grasses, Agropyron caninum, Bromus spp., and Festuca idahoensis. When used as sheep range, the manager should consider the reaction of the major forbs as we11. Mueggler (1967) determined that the three major forage grasses and two frequently abundant forbs (Aster integrifolius and Potentilla gracilis) are most sensitive to herbage removal when grazed during the period from early flowering to seed ripening. Julander (1968) found that Geranium viscosissimum was unable to withstand repeated removal of 50 percent of its herbage during late flowering. This sensitive stage of growth is just prior to and during the early part of the period when plants store carbohydrates in roots and root crowns (McCarty and Price 1942). Repeated heavy use at this time can be very detrimental. However, the short length of the summer season when these areas are accessible to livestock severely limits grazing alternatives on this very productive type. A rotation system of grazing would seem appropriate under such conditions. 
Additional information on management of the Festuca idahoensis series that is applicable to this habitat type is discussed in the FEID/AGSP h.t. section.

\title{
Festuca idahoensis /Carex filifolia h.t.
}

\author{
(FEID/CAFI h.t.)
}

Distribution and environment.--This is an infrequent habitat type generally confined to the higher elevations in southwestern Montana. Examples were found in the Bull Mountains north of Whiteha11, the Gravelly Range south of Virginia City, and the Pioneer Mountains northwest of Dillon. The type occurs on rather gentle topography (5 to 20 percent slope) in or near mountain saddles at elevations between 7,800 and $9,200 \mathrm{ft}(2,400$ and $2,800 \mathrm{~m})$. Soils are typically well protected by plant growth and litter. Sampled stands had less than 5 percent bare soil and very little surface rock.

Vegetative composition.--The absence of a dominant Agropyron and the constant association and abundance of Carex filifolia, Danthonia intermedia, Geum triflomu, and Gentiana affinis with Festuca idahoensis delineate this type (fig. 11) from others within the Festuca idahoensis series. Agropyron caninum and Carex petasata are other constant graminoids; Carex rupestris occasionally forms a substantial part of the community. Other constant forbs include Achillea millefolium, Agoseris glauca, Antennaria rosea, Arenaria congesta, Cerastium arvense, Polygonum bistortoides, and Potentilza spp. (appendix E4). Shrubs are virtually nonexistent in this type.
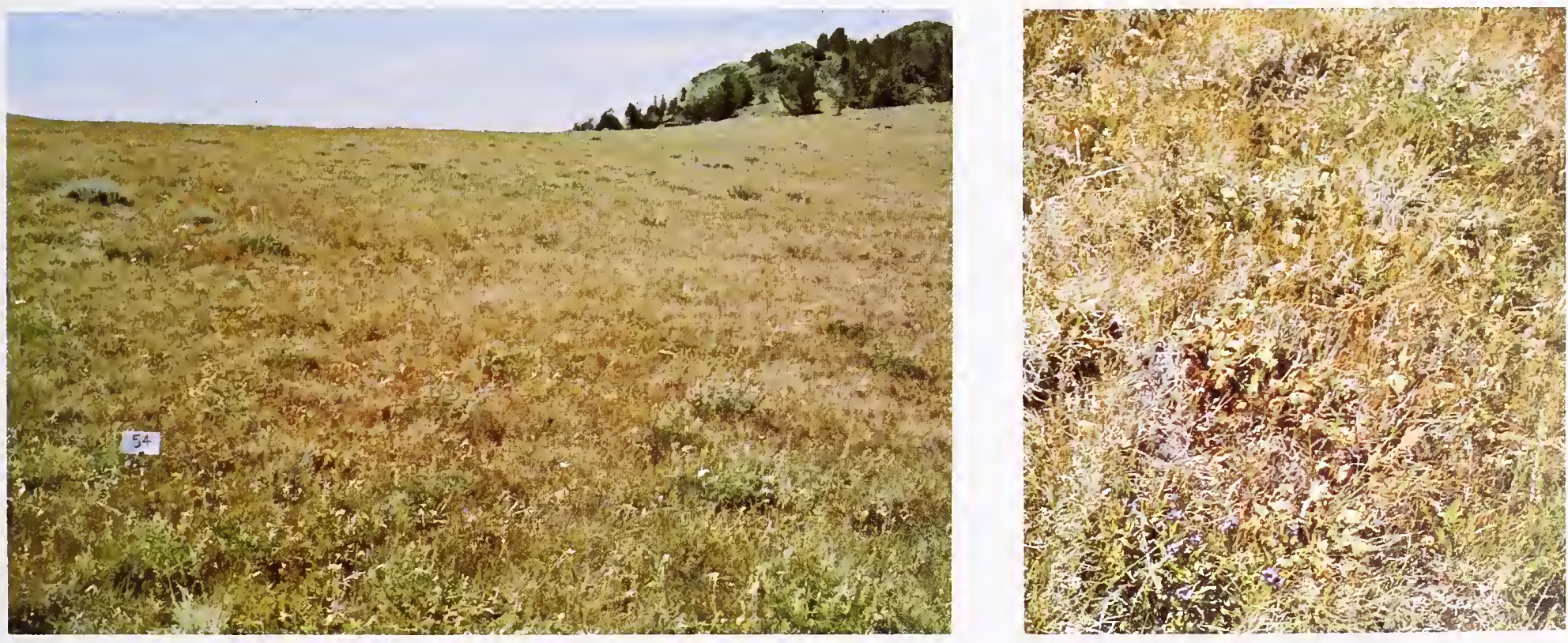

Figure 11.-Festuea idahoensis/Carex filifolia h.t. on Bull Mountain at 7,900 ft elevation near Whitehall in southwestern Montana.

Productivity.--We do not have a direct measure of productivity for this relatively infrequent habitat type. However, its vegetation is morphologically similar to the less productive portions of the FEID/AGSP h.t., which produce about 800 lb/acre (896 $\mathrm{kg} / \mathrm{ha})$. 
Judging from canopy-cover data (appendix E4), approximately 50 percent of the vegetation consists of fair to good forage species. Festuca idahoensis, Carex filifolia, and Danthonia intermedia comprise the bulk of this forage. Approximately 50 percent of the canopy cover is composed of forbs, most of which are low in forage value.

Changes with grazing.--A general listing of species response to grazing in the Festuca idahoensis series is given in the discussion of the FEID/AGSP h.t. The major forage species in the FEID/CAFI h.t. that will probably decrease with heavy grazing are Festuca idahoensis and Agropyron caninum. The primary species that will probably increase are Danthonia intermedia, Achillea millefolium, Geum triflomm, and Antennaria rosea. The response of Carex filifolia and Carex petasata will probably be to increase, at least initially.

Range management.--The FEID/CAFI h.t. is about equally suited for cattle or sheep grazing. Its high elevation occurrence restricts use to summer only. The type usually is confined by local topo-edaphic conditions and does not cover extensive areas. Consequently, management must be closely integrated with use of adjacent vegetation types. Management guides related to the primary forage grass, Festuca idahoensis, are discussed in the FEID/AGSP h.t. section.

Noted elsewhere.--Somewhat similar communities occur in the Big Horn Mountains of northern Wyoming. Hurd (1961) described a Festuca idahoensis/Lupinus serecius association there; the major difference betweeen it and our Montana FEID/CAFI h.t. is the prevalence of Carex obtusata as an associate in the Wyoming type instead of Carex filifolia. Despain (1973) also described Festuca idahoensis communities in that area in which the major associates are Carex obtusata, Iupinus serecius, and Agroseris grauca.

\title{
Festuca idahoensis/Stipa richardsonii h.t.
}

\author{
(FEID/STRI h.t.)
}

Distribution and environment.--This is another uncommon habitat type; however, it has been observed at widely scattered locations on both sides of the Continental Divide and in Yellowstone National Park. Sampled stands ranged widely in elevation from 3,600 to $6,900 \mathrm{ft}(1,100$ to $2,100 \mathrm{~m})$, and occurred on rather gentle slopes and on moderately deep soils. Very little bare soil or surface rock was apparent. The FEID/STRI h.t. is considered a moderately mesic and relatively productive grassland type.

Vegetative composition.--The predominance of Stipa pichardsonii (33 to 41 percent canopy cover) associated with Festuca idahoensis and the absence of a dominant Agropyron separate the FEID/STRI h.t. (fig 12) from other types in the Festuca idahoensis series. Danthonia intermedia, Stipa occidentalis, and Geranium viscosissimum are always present and usually abundant. A wide variety of other species is usually found, with Potentilla gracilis, Chrysopsis villosa, Achillea millefolium, Galium boreale, and carex petasata being the more conspicuous. Rosa askansana is the only shrub that ever occurs in abundance. The often striking display of spreading flower panicles of Stipa richardsonii is characteristic of the type in mid-and late summer. 

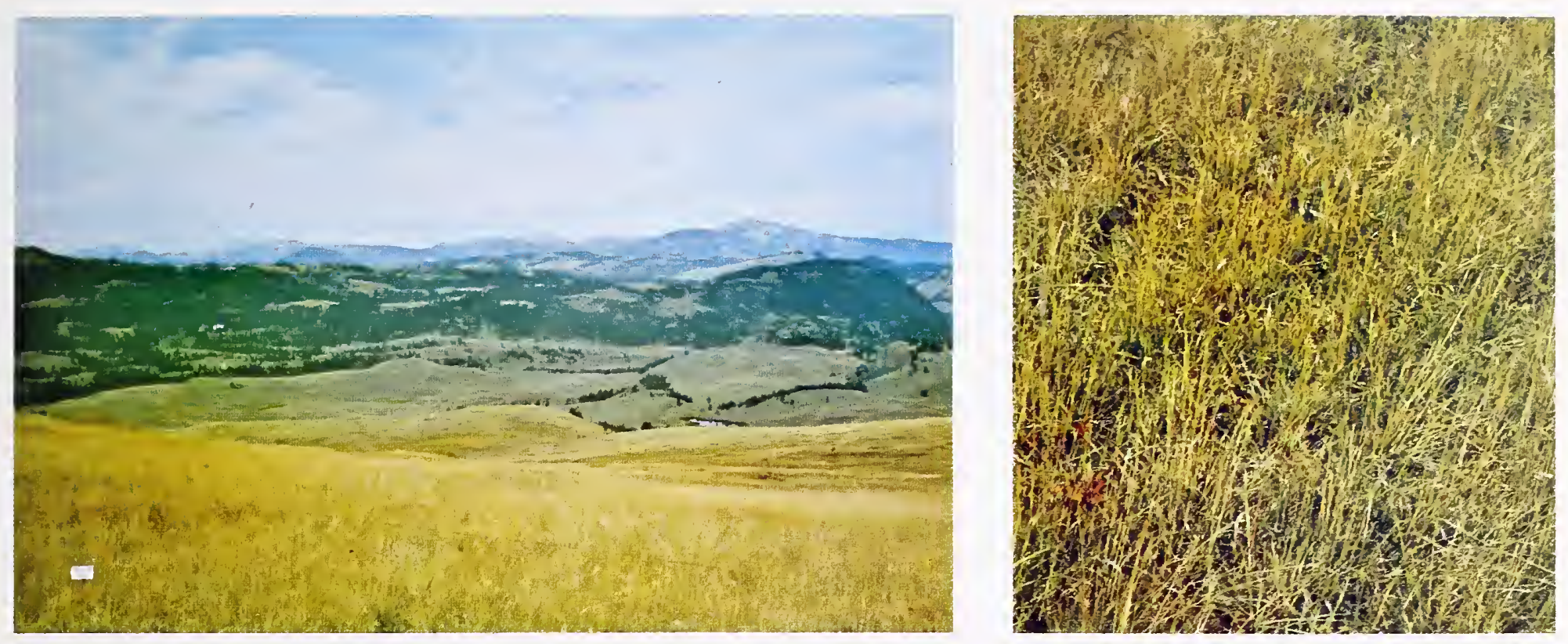

Figure 12.--Festuea idahoensis/Stipa richardsonii h.t. at 6,880 ft elevation in Yellowstone National Park.

Productivity.--The structure of this uncommon type is similar to that of the less luxuriant portions of the FEID/AGCA h.t., which produce about 1,200 1b/acre $(1,344$ $\mathrm{kg} / \mathrm{ha}$ ). Approximately 60 percent of this total, judging from canopy cover values (appendix E4), consists of graminoids which are relatively good forage species. Stipa richardsonii and Stipa occidentalis together make up about a third and Festuca idahoensis about a tenth of the total biomass. Low palatability forbs constitute about 40 percent of the total vegetation. Rosa arkansana, the only shrub that occurs in any abundance, averages about 3 percent of the total canopy cover.

Changes with grazing.--In this habitat type, Festuca idahoensis, Agropyron caninum, and Geranium viscosissimum generally are the principal forage species that decline with heavy grazing. The status of Stipa richardsonii, Stipa occidentalis, and the principal shrub Rosa arkansana is unclear. The species most likely to increase under heavy grazing are Danthonia intermedia, Chrysopsis villosa, and possibly Achillea millefolium and Galium boreale. A listing of the general reaction of species to grazing in the Festuca idahoensis series is given in the discussion of the FEID/AGSP h.t.

Range management.--This infrequent type appears equally suited as summer range for cattle or sheep. It generally produces an abundance of palatable grasses as well as a wide variety of forbs. Management guides related to Festuca idahoensis are discussed in the FEID/AGSP h.t. section. Specific requirements of the other major forage grasses are lacking. Proper management of the type probably will not differ appreciably from management appropriate for the FEID/AGCA h.t.; the environment and species are similar between the two types except for the abundance of Stipa richardsonii. 


\title{
Festuca idahoensis /Deschampsia caespitosa h.t.
}

\author{
(FEID/DECA h.t.)
}

Distribution and environment.--This is a subalpine meadow type (fig. 13) found on relatively gentle slopes at elevations between about 8,000 and $10,000 \mathrm{ft}(2,500$ and $3,000 \mathrm{~m})$. Although not abundant, the type was encountered on both sides of the Continental Divide generally south of $47^{\circ}$ latitude. The loamy soils are derived from a wide variety of parent materials. Soil surface is usually well protected, with bare soil averaging less than 3 percent for the eight stands sampled.
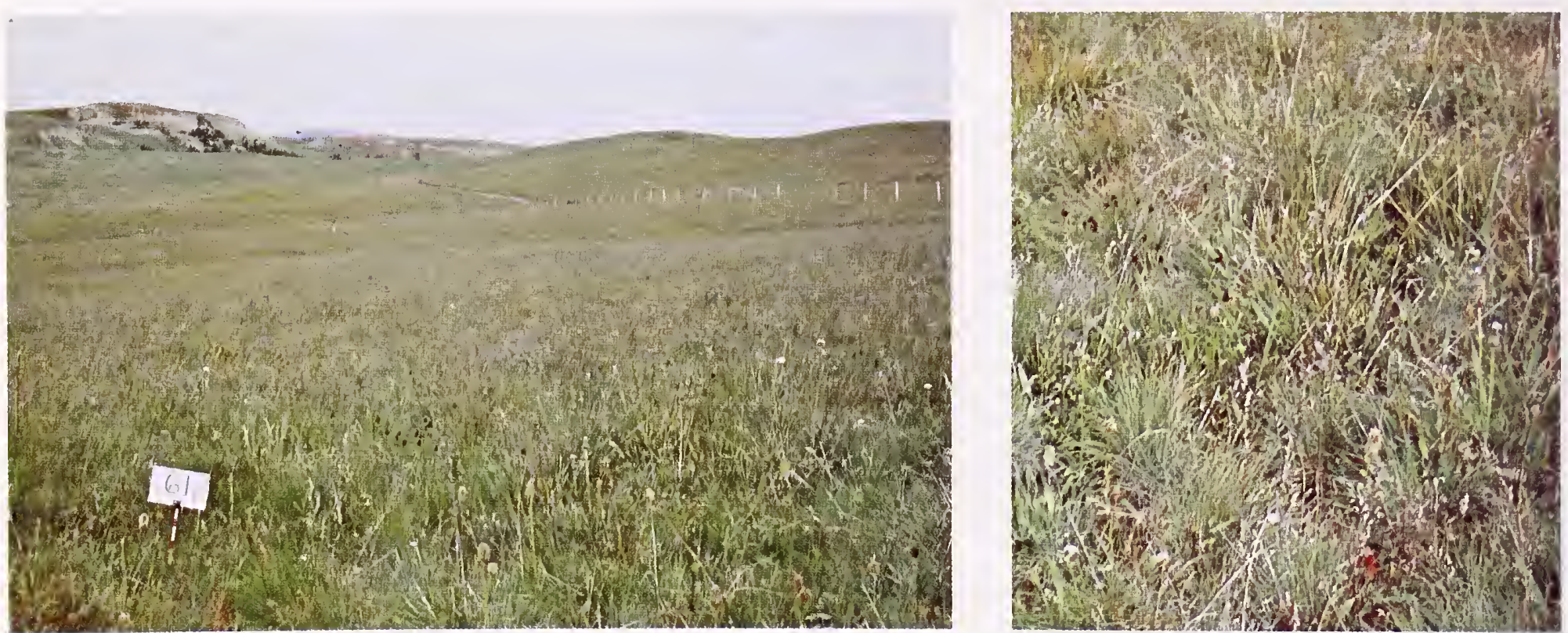

Figure 13.--Festuca idahoensis/Deschampsia caespitosa h.t. at 9,250 ft elevation on top of the Gravelly Range in southwestern Montana.

Vegetative composition.--Deschampsia caespitosa and Festuca idahoensis are the only constant graminoids and are generally the most productive ones in this high elevation grassland. Other graminoids commonly present in lesser quantities are Agropyron caninum, Phleum alpinum, Luzula spicata, Danthonia intermedia, and Carex scirpoidea (appendix E4). Forbs as a class are generally abundant, averaging 50 percent canopy cover. Polygonum bistortoides, Potentilla diversifolia, and Trilfolium spp. are the most constant; Lupinus argenteus and Achillea millefolium are sometimes abundant. Shrubby species are usually absent. At the highest elevations, Festuca idahoensis may be associated with or replaced by Festuca ovina.

Productivity.--We did not measure productivity of this habitat type. However, the vegetation appears structurally similar to that of the FEID/AGCA h.t., but with a somewhat shorter and perhaps denser cover. Total production probably ranges between 1,200 and $1,500 \mathrm{lb} / \mathrm{acre}(1,344$ and $1,680 \mathrm{~kg} / \mathrm{ha})$, equally divided between graminoids and forbs. Carex spp. of only fair palatability may be common. Festuca idahoensis and Deschampsia caespitosa are the most consistently important forage producers. Agropyron caninum, Stipa occidentalis and Danthonia intermedia may be productive in some locations. A wide variety of forbs exists, most of which are at best only moderately palatable. Shrubs are seldom encountered. 
Changes with grazing.--The principal species that are likely to decrease with overgrazing in this habitat type are Deschampsia caespitosa, Agropyron caninum, Phleum alpinum, and Festuca idahoensis. Principal species that will probably increase are Danthonis intermedia, Potentilla diversifolia, Geum triflomm, and Polygonum bistortoides. The response of other species to overgrazing in the Festuca idahoensis series is covered in the discussion of the EEID/AGSP h.t.

Range management.--Since this type occurs only at high elevations, livestock use is restricted to a relatively short summer grazing season. The type appears equally suited for cattle and sheep. Usually the type is restricted by topo-edaphic conditions at these high elevations and does not cover very large areas. Grazing influences on the type have not been studied.

\title{
Deschampsia caespitosa / Carex spp. h.t.
}

\author{
(DECA/CAREX h.t.)
}

Distribution and environment.--The DECA/CAREX h.t. is a distinct meadow type found on poorly drained, high elevation valley bottoms and other flat areas commonly flooded by late spring and early summer snow melt. We encountered this type (fig. 14) on both sides of the Continental Divide, usually at elevations between 6,000 and 9,000 $\therefore t(1,800$ and $2,700 \mathrm{~m})$. The soils are usually deep and poorly drained, with water standing on the soil surface at least during the early part of the growing season. The soil surface is ordinarily completely covered by vegetation and litter. This is considered the most moist mountain grassland habitat type occurring in western Montana.
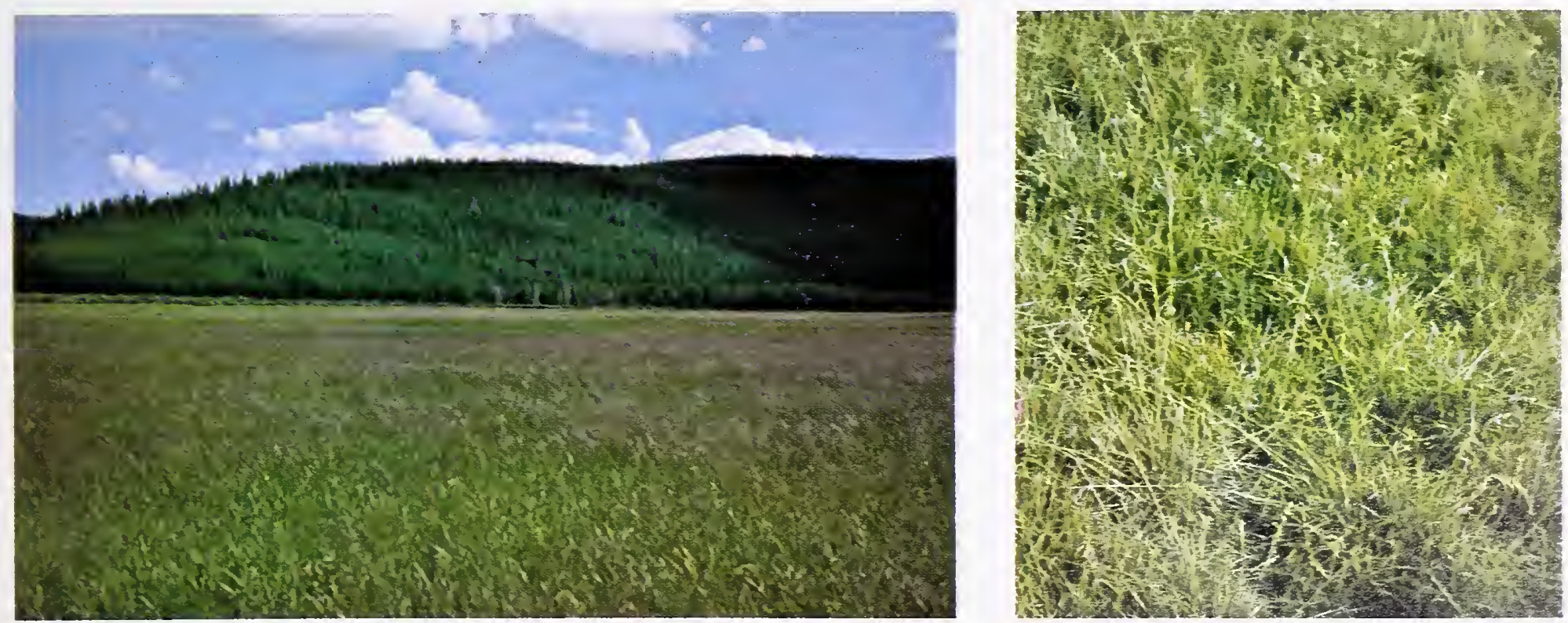

Figure 14.--Deschampsia caespitosa/Carex spp. h.t. west of Whitefish in northwestern Montana. This type frequently occupies mountain meadows with poorly drained soils.

Vegetative composition.--Deschampsia caespitosa is always abundant in this type. Other species are not consistently present, although one or more members of the Carex genera are always present. Danthonia intermedia, Phleum alpinum, and species of Agrostis and Juncus are usually present. Agropyron and Festuca species are conspicuously absent. The most commonly occurring forbs are Potentilla gracilis, Antennaria comymosa, and Polygonum bistortoides (appendix E5). 
Productivity.--The DECA/CAREX meadows are potentially the most productive grasslands in western Montana. Ample soil moisture available during a good part of the growing season and relatively deep soils contribute to lush growth. We measured production on only one stand in this type and obtained $2,595 \mathrm{lb} / \mathrm{acre}(2,906 \mathrm{~kg} / \mathrm{ha})$ dry matter. Ninety-nine percent of this consisted of graminoids, of which 26 percent was Deschampsia caespitosa and 56 percent was various species of Carex. Canopy cover from 6 stands (appendix E5) suggests that most meadows have fewer sedges than this and more forbs. Judging from these data, about 50 percent of the production will usually consist of palatable grasses, about 30 percent of moderately palatable sedges and rushes, and about 20 percent of a mixture of forbs generally low in palatability.

Changes with grazing.--Although our basis for judging species reaction to grazing in the DECA/CAREX h.t. is poor, certain changes are likely. The principal species that will probably decrease with heavy grazing are Deschampsia caespitosa, Phleum alpinum, and Agrostis spp. Those that will probably increase are Juncus spp., Danthonia intermedia, Antennaria corymbosa, Achillea millefolium, Polygonum bistortoides, and Potentilla diversifolia. Both Poa pratensis and Taraxicum officinale are probable invaders. The various species of Carex will very likely tend to increase.

Range management.--These meadows are among the best summer range in western Montana for cattle. Suitability for sheep is not as great because of the predominantly graminoid vegetation. Although the meadows may be accessible to livestock fairly early in the summer, use should be discouraged until the soils are no longer saturated with water. Pickford and Reid (1942) indicate that use of such meadows before the soils are firm enough to withstand trampling can be very damaging. Since both elk and deer commonly frequent these lush mountain meadows, care must be taken to avoid use conflicts between livestock and wildlife.

From studies of similar meadows in eastern Oregon and Washington, Reid and Pickford (1946) concluded that proper use of Deschampsia caespitosa can be as high as 55 percent, and the associated forage species can be utilized to about 50 percent. Pond (1961) observed that clipping similar mountain meadows in northern Wyoming to a $3-$ in $(7.6-\mathrm{cm})$ height every 2 weeks harmed nroduction but not plant density. More intensive clipping reduced density as well. However, he observed that clipping to a $1-$ in $(2.5-\mathrm{cm})$ height at the end of the growing season had little effect on the native meadow plants.

The condition classes of Deschampsia caespitosa series meadows in eastern Oregon and Washington described by Reid and Pickford (1946) may be generally appropriate for our western Montana meadows as well. They indicate that good to excellent condition is typified by a dense stand of Deschampsia caespitosa. Condition is only fair when this dominant grass becomes patchy and interspersed with areas of such showy forbs as Senecio spp., Erigeron speciosus, and Potentizla arguta. The drier, better-drained portions of the meadows decline most rapidly. On moderately dry sites, Poa pratensis and Agrostis spp. begin to increase as conditions decline. Koeleria cristata, Danthonia intermedia, and Bromus spp. increase on the driest sites. On poor condition meadows, Deschampsia caespitosa is found only as small patches. The wet areas are dominated by Carex spp. and Juncus spp. and the drier sites by a cover of such forbs as Antennaria corymbosa, Potentilla diversifolia, Agoseris glauca, and Gentiana affinis.

Most often, range habitat types in mountainous topography are not large enough to be managed as single units. The use of any one type, therefore, must be coordinated with requirements of adjacent types included within the allotment pasture. The DECA/CAREX h.t. can be a management problem as well as a useful grazing indicator in such situations. Cattle tend to concentrate on and graze these meadows heavily before moving out to drier types (Smith and others 1967). Consequently, the meadow bottoms are usually heavily grazed before the adjacent slopes are grazed appreciably. 
Overuse and trampling of the meadow bottoms frequently causes stream erosion and channeling. This in turn lowers the water table, alters soil moisture relations, and reduces productivity. Pickford and Reid (1942) indicate that rotation and deferment is essential for maintaining productivity of such meadows. When a meadow is large enough, the potential productivity may warrant dividing the meadow into separate pastures for intensive management. Not including adjacent slopes of widely different vegetation and topography in the pasture would simplify overall management.

Noted elsewhere.--Mountain meadows dominated by Deschompsia caespitosa and various species of Carex are scattered throughout the northwestern states. They are physiognomically similar, have Deschompsia caespitosa as a major dominant, and share many genera. Other species, however, differ between various geographical areas.

Schlatterer (1972) described a tufted hairgrass meadow community for central Idaho dominated by Deschompsia caespitosa with Carex praegracilis, Carex spp., Agrostis scabra, and Trifolium spp. as associates. In eastern Oregon, Hall (1973) recognized a moist meadow community type dominated by Deschampsia caespitosa with Carex microptera, Agrostis spp., Poa pratensis, and Danthonia califomica as major associates. Volland (1976) described a moist hairgrass meadow community type for central Oregon dominated by Deschampsia caespitosa, with Carex pachystachya, Carex nebraskensis, Juncus balticus, Calamagrostis canadensis, and Aster occidentalis as major associates.

\title{
Artemisia arbuscula IAgropyron spicatum h.t.
}

\author{
(ARAR/AGSP h.t.)
}

Distribution and environment.--The ARAR/AGSP h.t. is one of the driest mountain shrubland types occurring in western Montana. Communities of this type are found primarily on foothill areas east of the Divide and south of $47^{\circ}$ latitude. Usually they occur on southerly and westerly exposures, on slopes as steep as 37 percent, and at elevations between 4,500 and $7,700 \mathrm{ft}(1,400$ and $2,300 \mathrm{~m})$. The soils are commonly dry and rocky, with large amounts of bare soil and surface rock (appendix D).

Vegetative composition.--Morris and others (1976) indicate that both Artemisia arbuscula and Artemisia nova occur in southwestern Montana, with the latter probably being most widely distributed. However, since Hitchcock and others (1955-69) treat Artemisia nova as a variety of Artemisia arbuscula, we did not attempt to separate this variety in the field. Both have been lumped into the ARAR/AGSP h.t. Refinement of the classification may well necessitate recognition of a separate habitat type occupied by Artemisia nova. Artemisia arbuscula alone or in combination with Artemisia tridentata create the shrubby aspect in this shrubland type. Agropyron spicatum is the dominant herbaceous species; Koelemia cristata and Poa sandbergii are other constant grasses. Forbs are not abundant (2 to 20 percent canopy cover). Although a variety of forbs may occur, only Phlox hoodii and Iinum perenne are usually constant. Opuntia polyacantha is the most common low-growing shrub (appendix E6). On the deeper soils in this type, Artemisia tridentata is usually associated with and may be even more abundant than Artemisia arbuscula. Phlox hoodii may also be more prominent on these heavy soils.

The Stipa comata phase (STCO) delineates the sandier soil areas where Stipa comata is conspicuous. Oryzopsis hymenoides is a frequent associate on these areas, as are Gutierrezia sarothrae and Artemisia frigida. 
Productivity.--Our information on production in this type is sketchy. Harner and Harper (1973) found total production of somewhat similar vegetation in Utah to be 970 1b/acre $(1,086 \mathrm{~kg} / \mathrm{ha})$, of which $360 \mathrm{lb} /$ acre $(403 \mathrm{~kg} / \mathrm{ha})$ were graminoids and $120 \mathrm{lb} / \mathrm{acre}$ $(134 \mathrm{~kg} / \mathrm{ha})$ were forbs. This amount of herbaceous understory to the Artemisia corresponds well with the $411 \mathrm{lb} / \mathrm{acre}(460 \mathrm{~kg} / \mathrm{ha})$ reported by Hall (1973) for a low sagebrush-bunchgrass type in eastern Oregon similar to our ARAR/FEID h.t. Schlatterer (1972) indicates that total "forage" production in the ARAR/AGSP h.t. in central Idaho probably averages between 100 and $300 \mathrm{lb} / \mathrm{acre}(112$ and $336 \mathrm{~kg} / \mathrm{ha})$. In Montana we can reasonably expect this type to produce a total of 400 to 800 1b/acre (448 to 896 $\mathrm{kg} / \mathrm{ha}$ ) of which half is shrubs and half is herbaceous. The shrubs are primarily Artemisia arbuscula and Artemisia tridentata. Judging from our canopy-cover data (appendix E6), approximately two-thirds of the herbaceous understory will consist of palatable grasses, primarily Agropyron spicatum and Koeleria cristata, and one-third of forbs relatively low in palatability.

Changes with grazing.--Overgrazing in the ARAR/AGSP h.t. probably will result in a decrease in the abundance of Agropyron spicatum, Oryzopsis hymenoides, Eurotia Ianata, and possibly Stipa comata and Koeleria cristata. The principal species that will increase are Gutierrezia sarothrae, Artemisia frigida, Bouteloua gracizis, and possibly Poa sandbergii. Both Artemisia tridentata and Artemisia arbuscula tend to increase; if the area is badly overgrazed, Artemisia arbuscula will start to decrease. An indication of the reaction of other species within this type to heavy grazing can be obtained from the discussion of grazing within the Stipa comata and Agropyron spicatum series.

Range management.--This relatively low elevation shrubland type perhaps has greatest value as early spring and late fall cattle range. The presence of the Artemisia arbuscula shrub layer enhances the type's value for wildlife, particularly as deer winter range and as cover for sagegrouse. The sagebrush also complicates management because it competes with the desirable forage grasses for moisture and nutrients. Sagebrush increases with abusive cattle grazing to the detriment of forage production. However, the presence of Artemisia arbuscula can be a definite asset when the grasses are covered by snow; at such times it is fairly palatable and quite nutritious (Beetle 1960), particularly to sheep and deer.

Management considerations for the primary forage grasses are discussed in the $A G S P / B O G R$ h.t. section. Control measures for sagebrush are discussed in the ARTR/AGSP h.t. section. Artemisia arbuscula and Artemisia tridentata are expected to react similarly to burning and spraying.

Noted elsewhere.--Vegetation dominated by Artemisia arbuscula with a predominantly Agropyron spicatum understory occurs on arid sites in Idaho, Oregon, and Nevada as we11 as in Montana. Franklin and Dyrness (1969) described an Artemisia arbusculaAgropyron spicatum association that occurs on shallow, stony soils in eastern Oregon. Schlatterer (1972) found a similar type in Idaho that occurs on shallow or gravel1y soils with a restricted B-horizon. Stipa thurburiana was a common associate in this type rather than the Stipa comata found in the Montana type. Hironaka (1977) also observed this habitat type in southern Idaho. Zamora and Tueller (1973) and Lewis (1975) described an ARAR/AGSP h.t. in northern Nevada that contains the same dominants as the Montana type, but differs in associated species. For example, the Nevada type does not contain Gutierrezia sarothrae, Opuntia polyacantha, Koeleria cristata, or Linum perene, and contains Phlox Zongifolia instead of Phlox hoodii. 


\title{
Artemisia arbuscula/Festuca idahoensis h.t.
}

\author{
(ARAR/FEID h.t.)
}

Distribution and environment.--The ARAR/FEID h.t. is an infrequent type observed in the southwestern corner of Montana. It is generally found at higher elevations and under less xeric conditions than the ARAR/AGSP h.t. It has been found on dry mountain slopes at elevations as high as $9,100 \mathrm{ft}(2,800 \mathrm{~m})$ and as $10 \mathrm{w}$ as $6,200 \mathrm{ft}(1,900 \mathrm{~m})$. Communities of this type extend into Yellowstone National Park and environs and into adjacent areas of Idaho.

Vegetative composition.--The ARAR/FEID h.t. differs vegetatively from the ARAR/AGSP h.t. by the conspicuous amounts of Festuca idahoensis and the abundance of forbs (fig. 15). Artemisia arbuscula is the dominant shrub. In the higher elevation communities the Artemisia arbuscula may be ssp. thermopola. The predominant graminoids are Festuca idahoensis, Agropyron spicatum, and Koeleria cristata. The most common forbs are Antennaria rosea, Phlox hoodii, and Erigeron compositus (appendix E6).
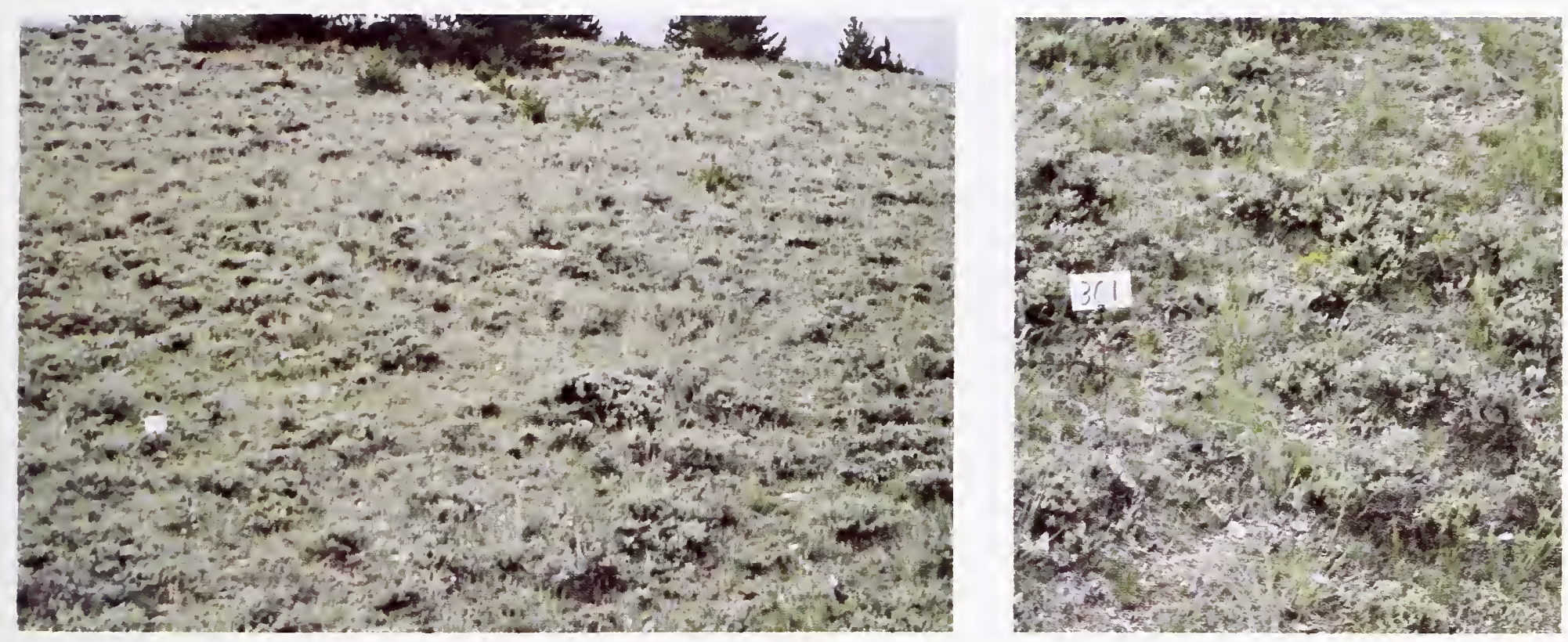

Figure 15.--Artemisia arbuscuto/Festuca idahoensis h.t. on a north slope at 6,200 ft elevation near Gardner in southwestern Montana.

Productivity.--The ARAR/FEID h.t. is slightly more productive than the ARAR/AGSP h.t. because it occurs on less arid sites. Hall (1973) reports that a similar type in eastern Oregon produced $411 \mathrm{lb} / \mathrm{acre}(460 \mathrm{~kg} / \mathrm{ha})$ of grasses and forbs. Schlatterer (1972) suggests that the ARAR/FEID h.t. in central Idaho will produce up to $400 \mathrm{lb} / \mathrm{acre}$ $(448 \mathrm{~kg} / \mathrm{ha})$. Total production for the ARAR/FEID h.t. in northern Nevada is reported to be about 400 to $500 \mathrm{lb} / \mathrm{acre}$ (448 to $560 \mathrm{~kg} / \mathrm{ha}$ ) of which 35 to 50 percent is sagebrush (Lewis 1975). Although we did not measure productivity of the type in Montana, we believe it should produce between 500 and $900 \mathrm{lb} / \mathrm{acre}$ (560 and 1,008 kg/ha) of total vegetation, about half of which is palatable grasses, a fourth shrubs (primarily Artemisia arbuscula), and about a fourth a variety of forbs of relatively low palatability. 
Changes with grazing.--A decrease in the principal forage producers, Agropyron spicatum and Festuca idahoensis, can be expected with overgrazing in this habitat type. Artemisia frigida, Poa sandbergii, and Phlox hoodii, along with the shrub Artemisia arbuscula, will be the principal species that increase. Artemisia arbuscula is a fairly palatable sagebrush that may decrease under continued heavy use. Very likely KoeZeria cristata and Antennaria rosea will also increase with grazing. An indication of the reaction of other species in this type to grazing can be obtained from the discussion of grazing effects in the Agropyron spicatum and Festuca idahoensis series.

Range management.--Since this type generally occurs at higher elevations than the ARAR/AGSP h.t., use is usually restricted to late spring, summer, and early fall. The highest elevation areas are usually accessible only in summer. The type is probably equally suited for use by cattle or sheep.

Management considerations related to the primary forage grasses, Festuca idahoensis and Agropyron spicatum, are discussed in the FEID/AGSP and AGSP/BOGR h.t. sections. Although Artemisia arbuscula is generally more palatable than Artemisia tridentata (Beetle 1960), control of this shrub may occasionally be desired. Sagebrush control is discussed in the ARTR/AGSP h.t. section. Artemisia arbuscula will respond similarly to Artemisia tridentata to direct control efforts, but very likely such control will not be economically acceptable.

Noted elsewhere.--Franklin and Dyrness (1969) and Hall (1973) describe communities dominated by Artemisia arbuscula and Festuca idahoensis in eastern Oregon. These Oregon communities also have a number of secondary species in common with the Montana ARAR/FEID h.t., e.g., Agropyron spicatum, Poa sandbergii, Phlox hoodii, and Phlox longifolia. Hironaka (1977) and Schlatterer (1972) reported similar communities in central Idaho occurring on shallow-soiled, flat benches up to elevations of 8,000 ft $(2,400 \mathrm{~m})$. Communities dominated by Artemisia arbuscula and Festuca idahoensis also occur in northern Nevada, but the secondary species differ appreciably from those in the Montana communities (Lewis 1975; Zamora and Tueller 1973).

\title{
Artemisia tridentata /Agropyron spicatum (MONT) h.t.
}

\author{
(ARTR/AGSP h.t.)
}

Distribution and environment.--Although the ARTR/AGSP h.t. (fig. 16) does not appear to be restricted geographically, we encountered it primarily in the southwest quarter of the State. The type occurs on various exposures, on slopes up to 54 percent, and at elevations from 4,000 to $6,000 \mathrm{ft}(1,200$ to $1,800 \mathrm{~m})$. It is found on shallow to moderately deep soils formed from a variety of parent materials. Even under good range conditions considerable rock (average 32 percent) and bare soil (average 11 percent) are present on the soil surface. Very likely this moderately arid type is restricted primarily to the 12 - to 18 -in $(30-$ to $46-\mathrm{cm})$ precipitation zone.

Vegetative composition.-Artemisia tridentata is the obvious dominant shrub in this type, with a canopy cover averaging 15 percent. Although subspecies of Artemisia tridentata were not differentiated in the field phases of our study, Artemisia tridentata ssp. wyomingensis and the low elevation form of Artemisia tridentata ssp. vaseyana (Morris and others 1976) are believed to prevail in this habitat type in Montana. Artemisia tridentata ssp. tridentata may be found occupying the deeper soils in swales and sandy drainage ways. Low shrubs, particularly Artemisia frigida and Gutierrezia sarothrae, are usually present. The herbaceous understory is dominated by Agropyron spicatum; other usually conspicuous grasses are Koeleria cristata, Poa sandbergii, 

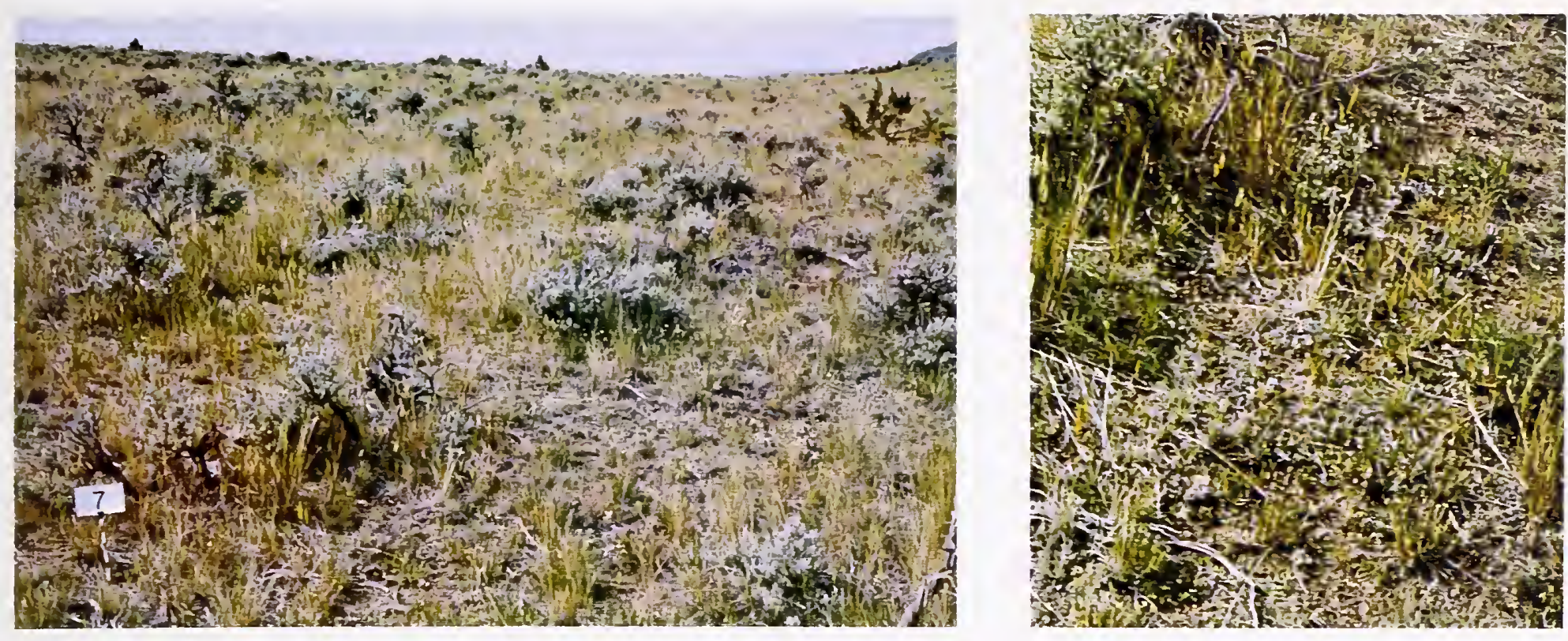

Figure 16.-Artemisia tridentata/Agropyron spicatum h.t. at 4,800 ft elevation in the Limestone Hills west of Townsend, Montana.

Stipa comata, and Bouteloua gracilis (appendix E7). Though a variety of forbs may be present, they generally are not abundant ( 1 to 18 percent canopy cover). No single forb species occurs consistently.

Productivity.--We measured production over a 3-year period on three relatively undisturbed sites within this habitat type. The sites were selected to span the range in site potential. Differences in total annual production between sites did not exceed 15 percent, and differences between years attributable to weather did not exceed 25 percent. However, differences between sites and between years for vegetation classes were considerably greater. Half again as much total grass and over four times as much total forbs were produced in one stand than in another. Shrub production was highest where either grass or forb production was low. Over the 3-year period, almost twice as much grass was produced in the high year as in the low year. The extremes in total production between stands and a measure of variability between years are presented in table 10.

Table 10.--Extremes in production and variabizity over a 3-year period in the Artemisia tridentata/Agropyron spicatum habitat type

\begin{tabular}{lcccc}
\hline \multirow{2}{*}{ Growth form } & \multicolumn{2}{c}{ Stand 8 } & \multicolumn{2}{c}{ Stand 239 } \\
\cline { 2 - 4 } & Average & SEI & Average & SEl \\
Graminoids & 278 & 48 & 427 & 40 \\
Forbs & 133 & 16 & 231 & 11 \\
Shrubs & 328 & 37 & 206 & 16 \\
$\quad$ Total & 739 & 71 & 864 & 43
\end{tabular}

\footnotetext{
${ }^{1}$ Standard error over 3-year period.

2Multiply by 1.12 for $\mathrm{kg} / \mathrm{ha}$.
} 
In similar vegetation in eastern Washington where Artemisia tridentata spp. tridentata is a dominant, Daubenmire (1970) found total production on long ungrazed and unburned sites to be 640 to $1,023 \mathrm{lb} /$ acre $(717$ to $1,146 \mathrm{~kg} / \mathrm{ha}$ ); between 44 and 60 percent of this consisted of perennial grasses. Two ungrazed Artemisia tridentata/ Agropyron spicatum communities in southern Idaho (Passey and Hugie 1963) produced only 337 and $682 \mathrm{lb} / \mathrm{acre}(388$ and $764 \mathrm{~kg} / \mathrm{ha}$ ), of which approximately 50 percent was grass, 20 percent forbs, and 30 percent shrubs. Lewis (1975) found that the Artemisia tridentata ssp. vaseyana/Agropyron spicatum h.t. in northern Nevada produced between 600 and $1,000 \mathrm{lb} / \mathrm{acre}(672$ and $1,120 \mathrm{~kg} / \mathrm{ha})$.

In the stands that we measured in western Montana, between 40 and 50 percent of the total production was grasses, 7 to 27 percent forbs, and the remainder was shrubs. Agropyron spicatum was the most important forage species, accounting for between 20 and 45 percent of the total vegetation production. Koeleria cristata, Poa sandbergii, and Stipa comata produce lesser amounts of forage. Although many species of forbs may be present, they do not contribute much to overall forage production because of low palatability. Artemisia tridentata usually accounts for more than 75 percent of the shrub production.

Changes with grazing.--Heavy grazing in this habitat type results primarily in a decrease of Agropyron spicatum and usually of Stipa vimidula, although the latter grass appears to persist better than Agropyron spicatum under heavy use. Such palatable forbs as Balsamorhiza sagittata and Crepis acuminata generally decrease when grazed heavily by sheep. Substantial increases can be expected in such grazing resistant grasses as Bouteloua gracilis and Poa sandbergii, and such unpalatable low shrubs as Artemisia frigida, Gutierrezia sarothrae, and Opuntia polyacantha. Stipa comata also may increase with excessive grazing, at least initially. The principal overstory shrub, Artemisia tridentata, is relatively unpalatable and usually increases readily as competition from the more palatable species is reduced. Bromus tectorum is usually the principal invader. The response of other species will probably be similar to the responses discussed for the Agropyron spicatum series.

Range management.--The ARTR/AGSP h.t. is best suited as early spring and late fall cattle range. It is less valuable for sheep because of the lack in abundance of forbs. Although Artemisia tridentata ssp. tridentata generally lacks palatability and is little used by livestock, ssp. wyomingensis is fairly palatable to both livestock and wildlife. Wildlife values may be high; depending upon location, the type is important winter range particularly for deer. Sagegrouse frequent the type as well.

Management considerations for the primary forage grass, Agropyron spicatum, are discussed in the AGSP/BOGR h.t. section. The usual abundance of Artemisia tridentata complicates management for the production of livestock forage. Decreased vigor of the palatable grasses and forbs inevitably results in an increase in the amount of this unpalatable shrub. Once established, Artemisia tridentata competes severely with the herbaceous understory and tends to suppress establishment of new grass plants (Blaisdell 1949). Dense stands of sagebrush also impede livestock movement and forage availability. Consequently, sagebrush control measures may be required occasionally to reduce competition from this shrub and to improve overall forage production.

Of the many methods for controlling sagebrush (burning, spraying, railing, beating, cutting, plowing) burning and spraying are the most economically feasible. These two methods are used primarily where a good understory of perennial grasses and forbs exists and will be released by a reduction in sagebrush. A doubling or even tripling (Hyder and Sneva 1956; Wilbert 1963) of herbaceous production is not uncommon wherever sagebrush is controlled. Each method of control, however, has disadvantages as well as advantages. For example, burning not only effectively kills sagebrush but also temporarily weakens the grasses (Blaisdel1 1953; Mueggler and Blaisde11 1958; Conrad and Poulton 1956). Spraying effectively kills sagebrush, but it tends to be detrimental 
to some forbs (Mueggler and Blaisdel1 1958) and may temporarily affect wildlife values adversely. Whereas burning usually removes most of the aboveground material, spraying leaves standing dead shrubs, which continue to impede animal movement for several years. This dead material, however, provides protection for the establishment of desirable grasses and forbs. Harniss and Murray (1973) found that the vegetation returned to essentially preburn conditions after 30 years, even under good range management. Thilenius and Brown (1974) found that increased herbage production following spraying for sagebrush control lasted on $1 y$ about 10 years. Where a good understory of perennial grasses and forbs do not exist, sagebrush control is ineffective unless accompanied by seeding desirable forage species. Pechanec and others (1965) discuss in detail the conditions where sagebrush control may be warranted, the various methods of control, the relative advantages of each, and posttreanment management.

Care should be taken to insure that sagebrush control is compatible with wildlife values. Both burning and spraying reduce brush cover and alter understory composition; this may be detrimental to some wildlife species. On the other hand, spraying sagebrush can be useful as a means of improving wildlife distribution. Wilbert (1963) found that elk are attracted to sprayed areas in late spring.

Pechanec and Stewart (1949) recommend a rotation grazing system for ARTR/AGSP spring-fall range. Although their work relates specifically to sheep, a rotation grazing system is a1so appropriate for cattle. It is important that the forage plants are not grazed year after year at a time in the spring when they are easily damaged. However, heavy fall use, particularly by sheep, can benefit the range by reducing the amount of sagebrush (Laycock 1967). A rest-rotation grazing system may be appropriate where rough topography tends to hinder uniform forage utilization. Concentrating large numbers of animals on an area for a limited period forces heavy but uniform use; rest periods then permit the vegetation to recover from the heavy use.

The amount of available herbage that should be utilized can be considerably greater in the fall than in the spring, when the plants are more sensitive to abuse. For sheep grazing good-condition ARTR/AGSP range on gentle topography, Pechanec and Stewart (1949) indicate that spring utilization of Agropyron spicatum should not exceed about 30 percent and Stipa comata, 50 percent. Fall utilization of these two species can be 45 and 70 percent, respectively. If the range is in only fair condition, utilization should be reduced approximately 10 percent.

Noted elsewhere.--Communities dominated by Artemisia tridentata and with Agropyron spicatum as the dominant understory are widespread throughout the Northern Rocky Mountains. Such communities have been described for southern British Columbia (Tisdale 1947), Washington (Daubenmire 1970), Oregon (Franklin and Dyrness 1969), Idaho (Mueggler 1950; Winward 1970; Schlatterer 1972; Hironaka 1977), Nevada (Lewis 1975), and Utah (Christensen 1963).

Although the ARTR/AGSP h.t. described by Daubenmire (1970) for eastern Washington has the same dominants and some of the same secondary species as our Montana ARTR/AGSP h.t., pronounced composition differences exist. The low shrubs Artemisia frigida, Gutierrezia sarothrae, and Opuntia polyacantha, and the grasses Koeleria cristata and Bouteloua gracilis, are usually conspicuous components in the Montana communities, but are lacking in the eastern Washington communities. Additional dissimilarities exist with the forbs. The most meaningful similarities are the dominance of Artemisia tridentata and Agropyron spicatum, and the importance of Stipa comata and Poa sandberii in the vegetation of both regions.

Winward (1970) partitioned the ARTR/AGSP h.t. in southeastern Idaho into two separate types based primarily upon the subspecies of sagebrush that was present. His Artemisia tridentata ssp. wyomingensis/Agropyron spicatum h.t. lacked Agropyron dasystachyum, had fewer forbs, and was generally more arid than his Artemisia tridentata ssp. vaseyana/Agropyron spicatum h.t. 


\title{
Artemisia tridentata/Festuca scabrella h.t.
}

\author{
(ARTR/FESC h.t.)
}

Distribution and environment.--The ARTR/FESC h.t. (fig. 17) occurs on both sides of the Continental Divide, but generally north of $46^{\circ}$ latitude. It is usually found on southerly exposures with less than 30 percent slope at elevations between 3,800 and $6,000 \mathrm{ft}(1,200$ and $1,800 \mathrm{~m})$. The soils are derived from various parent materials, and are usually moderately deep. Surface rock averages 16 percent and bare soil 4 percent. The type appears to occupy a rather broad precipitation zone, probably between 15 to 30 in $(40$ to $75 \mathrm{~cm})$. In this respect, the ARTR/FESC h.t. might be considered the northwestern Montana equivalent of the ARTR/AGSP and ARTR/FEID habitat types, which are found primarily in the southwestern portion of the State.
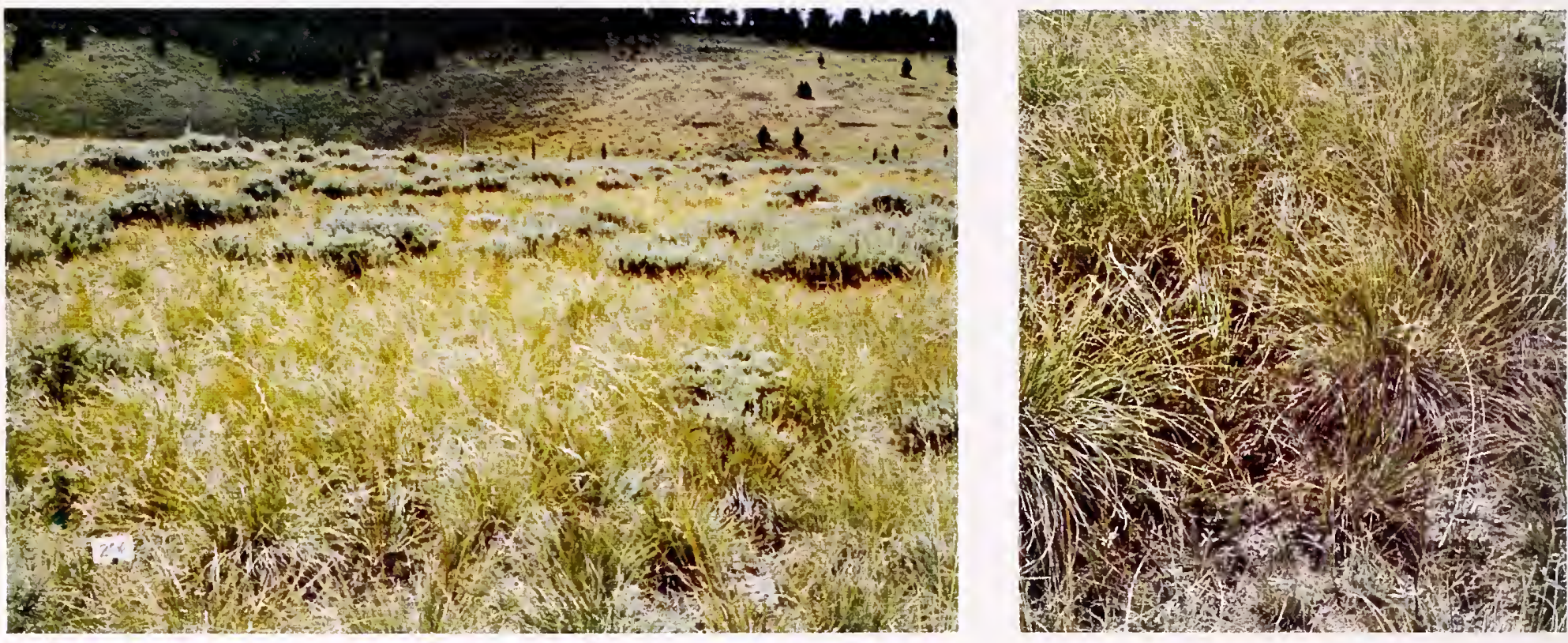

Figure 17.--Artemisia tridentata/Festuca scabrella h.t. in the Copper Creek Exclosures, 5,900 ft elevation, north of White Sulphur Springs, Montana.

Vegetative composition.--This habitat type is characterized by the association of Festuca scabrella with Artemisia tridentata. Both Artemisia tridentata ssp. wyomingensis and ssp. vaseyana are probably associated with Festuca scabrelza, with the latter dominant at the upper elevations of the habitat type. Agropyron spicatum and Festuca idahoensis are usually present and constitute a substantial portion of the herbaceous understory. Forbs are more abundant and varied here than in the ARTR/AGSP h.t. (appendix D). Generally, the most consistently occurring and abundant forbs are Antennaria rosea, Arenaria congesta, Achillea millefolium, Eriogonum umbellatum, and Cerastium arvense (appendix E7). Shrubs other than Artemisia tridentata are usually scarce.

Productivity.--Total annual production of vegetation in this habitat type appears comparable to that in the FESC/FEID h.t., between 1,100 and $1,600 \mathrm{lb} / \mathrm{bcre}(1,232$ and $1,792 \mathrm{~kg} / \mathrm{ha}$ ), but the proportion of usable forage is less. Judging from our canopycover data (appendix E7), only a little more than 50 percent of the total biomass consists of palatable grasses in contrast to more than 70 percent in the FESC/FEID h.t. The most productive forage species are Festuca scabrella, Festuca idahoensis, and Agropyron spicatum. A variety of forbs of questionable palatability comprise about 25 percent of the total biomass, and Artemisia tridentata about 20 percent. 
Changes with grazing.--The most apparent and likely changes with overgrazing of this habitat type will be a decrease in the palatable grasses Festuca scabrelza and Agropyron spicatum, and subsequent increase in the principal shrub Artemisia tridentata. The other common grasses, Festuca idahoensis, Poa cusickii, and Koeleria cristata may also increase initially but these species will decrease also if heavy grazing persists. The principal herbaceous species that probably increase with overuse are Cerastium arvense, Achillea millefolium, Arenaria congesta, Antennaria rosea, and Phlox hoodii. The response of other species to grazing will very likely be similar to their response in the Festuca scabrezla series.

Range management.--Management of the ARTR/FESC h.t. should be keyed primarily to the requirements of the most abundant forage grasses, Festuca scabrelza, Festuca idahoensis, and Agropyron spicatum. The relative abundance of these grasses will differ with specific sites, and management must be tailored to the existing conditions. Requirements of the primary forage species are discussed in the AGSP/BOGR, FESC/AGSP, and FEID/AGSP h.t. sections. The occurrence of Artemisia tridentata complicates management, for it is a strong competitor that usually increases appreciably when the range is overgrazed. Control of Artemisia tridentata is discussed in the ARTR/AGSP h.t. section.

\title{
Artemisia tridentata /Festuca idahoensis (MONT) h.t.
}

\author{
(ARTR/FEID h.t.)
}

Distribution and environment.--This habitat type (fig. 18) is found almost exclusively south of $46^{\circ} 30^{\prime}$ latitude in western Montana. In the northwestern quarter of the State, Festuca scabrella becomes a major co-dominant with Artemisia tridentata and replaces Festuca idahoensis as the characteristic associate. The ARTR/FEID h.t. occurs at elevations ranging from 6,000 to $8,000 \mathrm{ft}(1,800$ to $2,400 \mathrm{~m})$ on mountain slopes with usually less than 40 percent slope. This is a moderately mesic shrubland type that probably falls within the 16 - to $30-$ in $(40-$ to $75-\mathrm{cm})$ precipitation zone. The Geranium viscosissimum phase (GEVI) of the type is found generally at the upper part of the precipitation zone on northerly and easterly exposures and at elevations above $7,000 \mathrm{ft}(2,100 \mathrm{~m})$.

Soils from representative stands in the ARTR/FEID h.t. were classified as Typic Cryoboroll and Pachic Cryoboroll, with ustic moisture and cryic temperature regimens (Munn and others 1978). Solum thickness ranged from 16 to 33 in (41 to $84 \mathrm{~cm}$ ), with 4 - to 21-in (10- to $54-\mathrm{cm})$ A horizons. Depth of free calcium carbonate ranged from 16 to 40 in $(41$ to $102 \mathrm{~cm})$. Solums were slightly acid to neutral in reaction. Normally, the soil surface is well covered with vegetation and litter (appendix D). The Geranium viscosissimum phase generally occupies the deeper soils.

Vegetative composition.--Although both Artemisia tridentata ssp. wyomingensi.s and ssp. vaseyana probably occur within this habitat type, the latter is by far the most common dominant shrub. The type is characterized by the presence of Festuca idahoensis as the dominant grass understory, and by the absence of Festuca scabrella. Agropyron spicatum and Koeleria cristata are constantly associated with Festuca idahoensis. Forbs, especially Geum triflomum, are fairly abundant. The drier portion of this habitat type is likely to contain such shrubs as Chrysothamus spp. and Artemisia frigida as minor associates. 

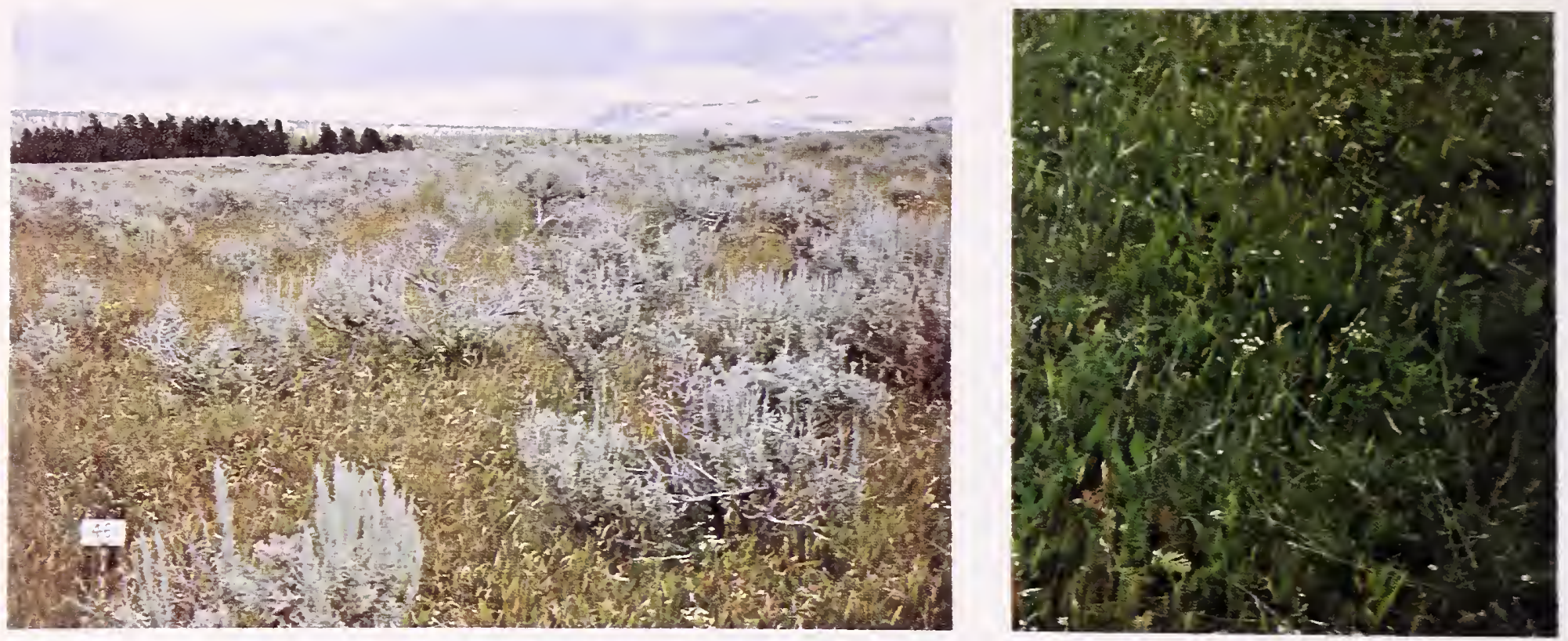

Figure 18.--Artemisia tridentata/Festuca idahoensis h.t. on the Cliff Lake Research Natural Area, 7,200 ft elevation, in Madison county, Montana. The scattered, multiaged populations of sagebrush has an abundant understory of grasses and forbs.

The more mesic portion of the type, the Geranium viscosissimum phase, is differentiated compositionally by a greater variety of graminoids and abundance of forbs as understory to the prevalent Artemisia tridentata overstory. The presence and often abundance of such graminoids as Danthonia intermedia, Bromus carinatus, Agropyron caninum, Stipa occidentalis, and Carex raynoldsii, as well as such forbs as Geranium viscosissimum, Potentilla gracilis, Potentilla arguta, Helianthella uniflora, and Erigonum umbellatum characterize this phase (appendix E7).

Productivity.--This type produces considerably more vegetation than the ARTR/AGSP h.t. The range in productivity, however, is fairly wide--almost a twofold difference in yield was found between stands selected to span the range in site potential. We found that total production on the better sites (Geronium viscosissimum phase) is comparable to that in the FEID/AGCA h.t., whereas the less productive sites are more comparable in production to the FEID/AGSP h.t. At most, about a 50 percent difference in annual production occurred over a 3 -year period because of weather differences. This was roughly the same as that found for the FEID/AGSP and FEID/AGCA habitat types, the shrubless equivalents of the ARTR/FEID h.t. Extremes in production between stands and a measure of variability over a 3-year period are presented in table 11.

Hall (1973) indicated that production of just grasses and forbs in similar vegetation in eastern Oregon is $412 \mathrm{lb} /$ acre (461 kg/ha). Schlatterer (1972) reported that total production of the ARTR/FEID h.t. in the mountains of central Idaho is usually 500 to $700 \mathrm{lb} / \mathrm{acre}(560$ to $784 \mathrm{~kg} / \mathrm{ha}$ ), but yields of more than $1,000 \mathrm{lb} / \mathrm{acre}(1,120 \mathrm{~kg} / \mathrm{ha}$ ) are possible. Wilbert (1963) measured yield on two western Wyoming sites similar to the ARTR/FEID h.t. These produced 682 to $1,728 \mathrm{lb} / \mathrm{acre}(764$ to $1,935 \mathrm{~kg} / \mathrm{ha})$, of which about 20 to 30 percent was grass, 30 to 35 percent forbs, and 40 to 50 percent shrubs. 
Table 11.--Extremes in production and variabizity over a 3-year period in the Artemisia tridentata/Festuca idahoensis habitat type

\begin{tabular}{|c|c|c|c|c|}
\hline \multirow[b]{2}{*}{ Growth form } & \multicolumn{2}{|c|}{ Stand 272} & \multicolumn{2}{|c|}{ Stand 46} \\
\hline & Average & SE 1 & Average & SEl \\
\hline & ---- & $-A i r$ & $b / a c r e e^{2}-$ & $-\cdots-\cdots$ \\
\hline Graminoids & 201 & 12 & 609 & 33 \\
\hline Forbs & 423 & 84 & 691 & 53 \\
\hline Shrubs & 139 & 27 & 144 & 27 \\
\hline Total & 769 & 103 & 1,443 & 44 \\
\hline
\end{tabular}

${ }^{1}$ Standard error over 3-year period.

${ }^{2}$ Multiply by 1.12 for $\mathrm{kg} / \mathrm{ha}$.

Mueggler and Blaisdell (1958) indicate that similar vegetation in southeastern Idaho averaged $742 \mathrm{lb} /$ acre $(831 \mathrm{~kg} / \mathrm{ha})$ over 3 years. During this period, approximately 40 percent more biomass was produced during the high year as during the low year. Approximately 30 percent of this production consisted of graminoids, 10 percent forbs, and almost 60 percent shrubs; sagebrush comprised almost 95 percent of the shrub production. Lewis (1975) reported production figures of 900 to $1,300 \mathrm{lb} / \mathrm{acre}(1,008$ to 1,456 $\mathrm{kg} / \mathrm{ha}$ ) for this type in northern Nevada.

In the Montana stands that we sampled for production, graminoids constituted 21 to 42 percent of the biomass, forbs 38 to 56 percent, and shrubs 10 to 41 percent. Most of the graminoid production consisted of palatable grasses; only in the Geranium viscossimum phase did an appreciable amount of sedges occur (appendix E7). Most of the forbs are rather poor forage, with the possible exceptions of Helianthella uniflora, Geranium viscosissimum, and Potentilla arguta which are found primarily in the Geranium viscosissimum phase. Eighty-eight to 98 percent of the shrub production in these Montana stands was Artemisia tridentata.

Changes with grazing.--Overgrazing of the type will cause a reduction of such palatable species as Agropyron spicatum and Festuca idahoensis. The unpalatable shrubs, Artemisia tridentata and Chrysothamnus viscidiflorus, will tend to increase as will the unpalatable forbs Geum triflorum, Arenaria congesta, and Achillea millefolium. In the Geranium viscosissimum phase of the type, Agropyron caninum, Bromus carinatus, Carex raynoldsii, and possibly Stipa occidentalis also may decrease appreciably with heavy cattle use. Continued heavy sheep use of this phase may cause a decrease in Helianthella unifloria, Potentilla arguta, Geranium viscosissimum, and possibly Potentizla gracilis. The reaction of other species to overuse will likely parallel the responses discussed for the Festuca idahoensis series.

Range management.--The ARTR/EEID h.t. is well suited as late spring to early fall range for all classes of livestock. Use at the higher elevations, however, may be restricted to just the summer season because of late plant development and early fall snows. The Geranium viscosissimum phase is particularly well suited for sheep because of the rich complement of forbs. The type frequently is important wildlife habitat, especially for mule deer and sagegrouse. 
A rest-rotation system of grazing is often preferred for the type because of the mountainous topography. Drainage bottoms usually receive heavy use while adjacent slopes are underused. The heavy, short-term stocking of a rest-rotation system combined with proper water development and fencing usually improves livestock distribution. Where topography is not a handicap, deferred rotation and season-1ong systems may suffice.

Many of the management considerations discussed in the FEID/AGSP and FEID/AGCA h.t. sections are also applicable to the ARTR/FEID h.t. The abundance of Artemisia tridentata, however, requires that consideration be given to control of this competitive shrub to improve forage production. Sagebrush control is discussed in the ARTR/AGSP h.t. section.

Noted elsewhere.--Communities dominated by Artemisia tridentata where Festuca idahoensis is a conspicuous understory grass are fairly widespread. Tisdale and others (1965), Winward (1970), Schlatterer (1972), and Hironaka (1977) described such communities in Idaho, Franklin and Dyrness (1969) and Hall (1973) in eastern Oregon, Lewis (1975) in Nevada, and Daubenmire (1970) in eastern Washington. Undoubtedly such communities occur also in western Wyoming and possibly in Utah.

The ARTR/FEID h.t. described by Daubenmire (1970) for eastern Washington apparently is dominated primarily by Artemisia tridentata ssp. tridentata, whereas Artemisia tridentata ssp. vaseyana is most common in the type in Montana. The Montana type also appears much richer in perennial herbs. This is particularly true for the Geranium viscosissimum phase which contains such grasses as Agropyron caninum, Bromus carinatus, Danthonia intermedia, Stipa occidentalis, Poa juncifolia, and Koeleria cristata, and such forbs as Campanula rotundifolia, Geum triflorum, Geranium viscosissimum, and Potentilla gracilis; these species are not listed for the type in washington. In contrast, Daubenmire's ARTR/FEID h.t. contains a much greater diversity and abundance of annuals than the Montana type.

Winward (1970) found that Festuca idahoensis becomes a codominant species in southeastern Idaho at about 6,500 to $7,000 \mathrm{ft}(1,981$ to $2,134 \mathrm{~m})$ elevation, with fingers extending to lower elevations on northeast facing slopes. He categorized this vegetation into two habitat types based upon the form of sagebrush present and upon different associated species. His Artemisia tridentata vaseyana/Festuca idahoensis h.t. is comparable to our ARTR/FEID h.t. His Artemisia tridentata vaseyana form spiciformis/ Bromus marginatus/Festuca idahoensis h.t. generally occurs above $7,000 \mathrm{ft}(2,134 \mathrm{~m})$ on cool mesic sites. It appears somewhat comparable to our Geranium viscosissimum phase of the habitat type.

\title{
Artemisia tripartita /Festuca idahoensis (MONT) h.t.
}

\author{
(ARTRI/FEID h.t.)
}

Distribution and environment.--Stands dominated by Artemisia tripartita are very localized in Montana; examples of the ARTRI/FEID h.t. (fig. 19) were observed only in the extreme southwestern part of the State. Usually this habitat type occurs on gentle alluvial slopes or benches with moderately deep soils. Bare soil ranged from 1 to 11 percent and surface rock cover from 0 to 25 percent on the five stands of this type that we sampled. The environmental distinction between this habitat type and drier stands in the ARTR/FEID h.t. is unknown. 

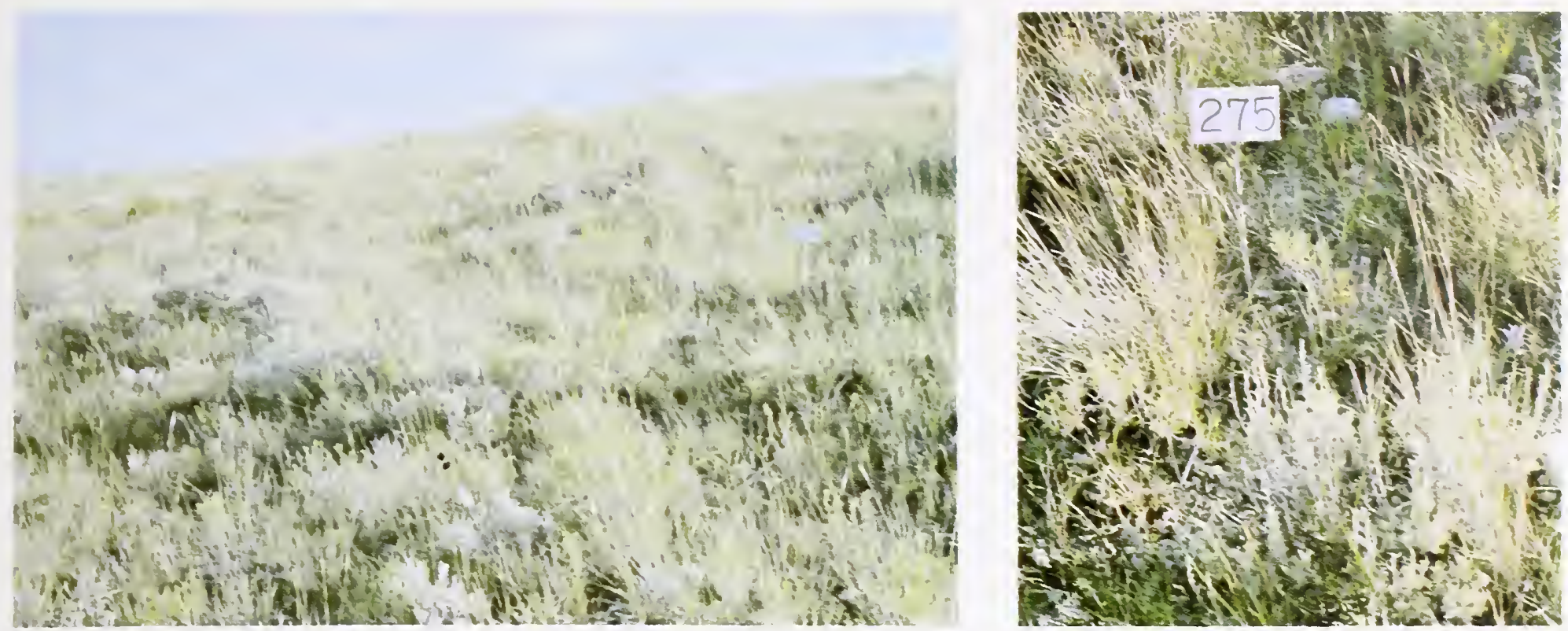

Figure 19.-Artemisia tripartita/Festuca idahoensis h.t. at 6,900 ft elevation near Dillon in southwestern Montana.

Vegetative composition.--This type is similar vegetatively to the drier portion of the ARTR/FEID h.t., except for the prevalent overstory of Artemisia tripartita and apparent association of Calamagrostis montanensis with Festuca idahoensis in the understory. The shrubs Chrysothamus viscidifloms, Tetradymia canescens, and Artemisia frigida are usually present. Although Artemisia tridentata may be present, it is not abundant. Festuca idahoensis, Koeleria cristata, and Calamagrostis montanensis are the principal graminoids; Stipa comata, Agropyron spicatum, and rhizomatous Agropyron spp. may also be abundant in some cases. Phlox hoodii, Antennaria rosea, and Lupinus sericeus are the principal forbs (appendix E8).

Productivity.--We did not sample vegetation production in this type. Very likely, however, it is similar to that of the drier part of the ARTR/EEID h.t.--about 800 to $1,200 \mathrm{lb} / \mathrm{acre}$ (896 to $1,344 \mathrm{~kg} / \mathrm{ha}$ ). Both of these types have similar structure, a mixed grass-forb understory to a dominating Artemisia shrub layer, and occur in similar environmental situations. Daubenmire (1970) found production of a stand of similar vegetation in eastern Washington to be $1,283 \mathrm{lb} / \mathrm{acre}(1,437 \mathrm{~kg} / \mathrm{ha})$, of which 85 percent was perennial grass. Schlatterer (1972) reports that production of the ARTRI/EEID h.t. in central Idaho ranges from 250 to $700 \mathrm{lb} / \mathrm{acre}(280$ to $784 \mathrm{~kg} / \mathrm{ha})$, which seems very low. Judging from our canopy-cover data (appendix E8), an average 69 percent of the biomass of Montana stands is palatable grass, 17 percent forbs of rather low palatability, and 14 percent shrubs of low palatability. The proportion of grasses appears considerably higher in the ARTRI/EEID h.t. than in the ARTR/EEID h.t.

Changes with grazing.--All of the shrubs within this habitat type are undesirable forage species and usually increase with heavy grazing. The most prominent of these are Artemisia tripartita, Chrysothamus viscidifloms, and Tetradymia canescens. The low shrubs, Gutierrezia sarothrae and Artemisia frigida, are also conspicuous increasers. As such palatable grasses as Agropyron spicatum, Agropyron caninum, and Eestuca idahoensis decrease with overuse, Calamagrostis mbescens, Agropyron dasystachyum, and Koeleria cristata may tend to increase; however, these latter three grasses will decrease under continued heavy use. Achillea millefolium and Phlox hoodii are generally the most prominent forbs to increase. Response to grazing of other species found in this habitat type will probably be similar to their response to grazing discussed in the Festuca idahoensis series. 
Range management.--Management considerations relevant to maintenance of forage production in the FEID/AGSP h.t. are appropriate for this type as well. However, the dominance of Artemisia tripartita complicates management. This shrub is an aggressive competitor, is relatively unpalatable, and, in striking contrast to Artemisia arbuscula and Artemisia tridentata, sprouts readily from the stump (Beetle 1960). Consequent1y, burning is not an effective control measure for Artemisia tripartita. Even though fire kills back the tops, stump sprouts may rapidly restore the shrub to a dominant position in the community. Spraying herbicides may be at least partly effective in controlling this species (B1aisdell and Mueggler 1956b).

Noted elsewhere.--An ATRI/FEID h.t. was identified in southern Idaho by Hironaka (1977). Schlatterer (1972) described an Artemisia tripartita--Festuca idahoensis community for central Idaho that lacks the rhizomatous Agropyron spp. and Calamagrostis montanensis which are fairly common in the Montana type. The ARTRI/FEID h.t. described by Daubenmire (1970) for eastern Washington also lacks a number of perennial species that are often abundant in the Montana version of the type. Among the more conspicuous of these are the aforementioned rhizomatous grasses, Phlox hoodii, Antennaria rosea, and Carex stenophyzla. On the other hand, Carex filifolia, Phlox Zongifolia, and many annuals are much more abundant in the Washington type than in the Montana type.

\title{
Potentilla fruticosa /Festuca scabrella h.t.
}

\author{
(POFR/FESC h.t.)
}

Distribution and environment.--The POFR/FESC h.t. is found on $1 \mathrm{y}$ north of $46^{\circ}$ latitude and primarily east of the Continental Divide. Usually it occurs on gently sloping or rolling topography at elevations between 4,500 and 6,000 ft $(1,372$ and $1,829 \mathrm{~m})$. The soils are moderately deep, 10 - to 18 -in $(25-$ to $45-\mathrm{cm}$ ) rooting depth, and usually of either limestone or sandstone parent materials. Considerable surface rock may be exposed, but usually very little bare soil is evident. Vegetation and litter cover commonly exceed 98 percent in the Donthonia intermedia phase (DAIN). This is a moderately mesic foothill type that probably falls within the 20 - to $30-$ in (50- to $75-\mathrm{cm})$ precipitation zone. The Danthonia intermedia phase occurs where moisture relations are better than average.

Vegetative composition.--The typal shrub, Potentilla fruticosa, may not be readily visible in this habitat type because of the tall vigorous growth of Festuca scabrella (fig. 20). However, Potentizza fruticosa is not only present but has a canopy cover usually between 5 and 30 percent. Festuca idahoensis and Koeleria cristata are secondary grasses usually associated with the overwhelmingly dominant Festuca scabrelza. Forbs frequently occur in great variety, the most prevalent being Galium boreale, Gailardia aristata, Achillea millefolium, Solidago missouriensis, and Campanula rotundifolia (appendix E9). On the drier sites, Agropyron spicatum, Carex scimpoides, Artemisia frigida, Gutierrezia sarothrae, Chrysopsis villosa, and Senecio canus are often conspicuous.

The Danthonia intermedia phase is typified by the presence of Danthonia intermedia in combination with the relative abundance of Agropyron canium, Potentilza gracilis, Lupinus sericeus, and Carex obtusata. 

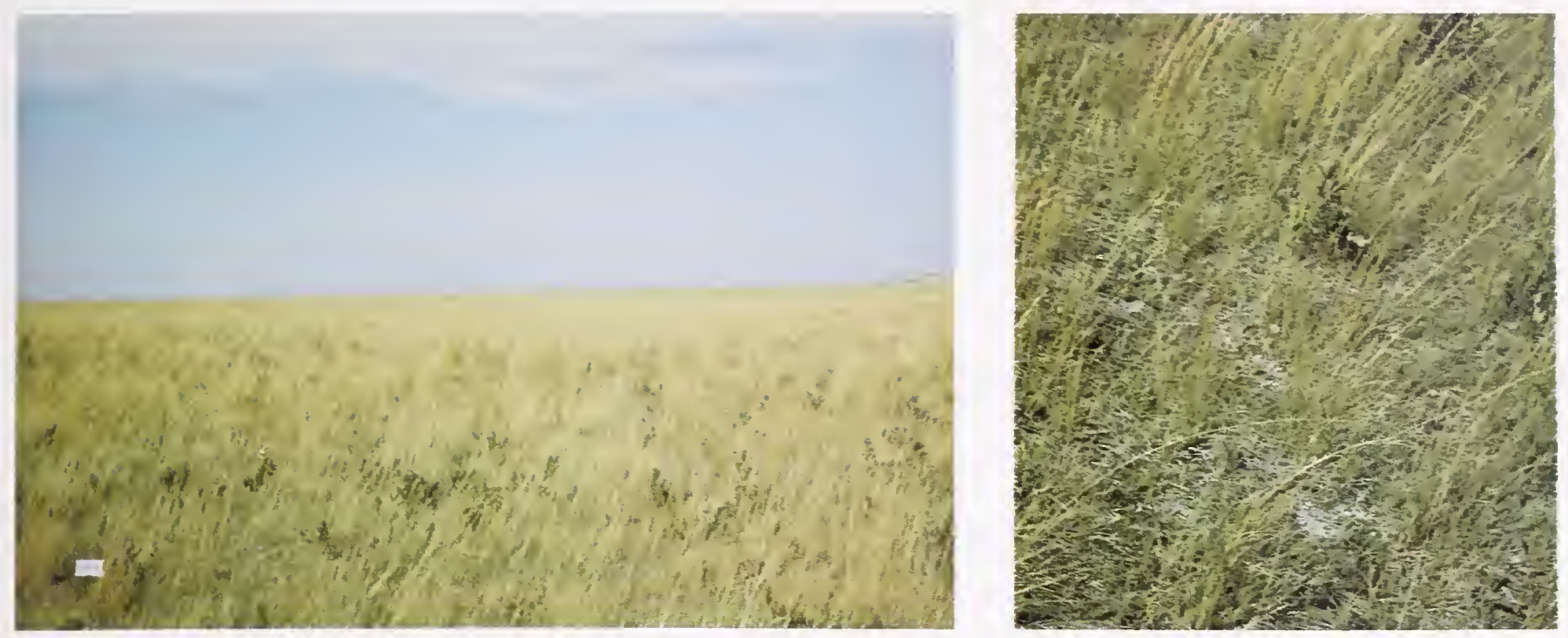

Figure 20.--Potentizla fruticosa/Festuca scabrelza h.t. ocurring where the plains meet the mountain, 4,340 ft elevation, near Dupuyer in northern Montana.

Productivity.--A large amount of variation in site potential and in yearly production exists in this habitat type. We found almost a twofold difference in total production between 3 stands selected to span the range in site potential. The Danthonia intermedia phase appeared most productive. We also found a twofold difference in production over a 3-year period because of yearly weather differences. Production of both the forb and shrub groups tended to be more variable than that of the grasses. The extremes in production between stands and a measure of variability between years are presented in table 12 .

Table 12.--Extremes in production and variability over a 3-year period in the Potentilla fruticosa/Festuca scabrella habitat type

\begin{tabular}{|c|c|c|c|c|}
\hline \multirow[b]{2}{*}{ Growth form } & \multicolumn{2}{|c|}{ Stand 354} & \multicolumn{2}{|c|}{ Stand 258} \\
\hline & Average & $\mathrm{SE}^{1}$ & Average & $\mathrm{SE}^{1}$ \\
\hline & --- & $--A i$ & $c r e^{2}--$ & ----- \\
\hline Graminoids & 676 & 97 & 1,155 & 138 \\
\hline Forbs & 194 & 58 & 436 & 93 \\
\hline Shrubs & 50 & 12 & 169 & 64 \\
\hline Total & 920 & 157 & 1,773 & 271 \\
\hline
\end{tabular}

${ }^{1}$ Standard error over 3-year period.

${ }^{2}$ Multiply by 1.12 for $\mathrm{kg} / \mathrm{ha}$. 
Usually almost 75 percent of the total vegetative biomass consists of palatable graminoids, about 20 percent forbs of questionable forage value, and less than 10 percent shrubs. Festuca scabrella ordinarily constitutes about two-thirds of the graminoid production. Other substantial forage producers may be the highly palatable Agropyron spicatum and Poa pratensis, and the moderately palatable Danthonia parmi and Danthonia intermedia (appendix E9). Many different forbs may be present, but no single species appears to be a substantial producer of livestock forage. The shrubs produce little usable forage.

Changes with grazing.--Potentilla fruticosa fills a role in this series similar to Artemisia tridentata in its series. Both are shrubs unpalatable to livestock, and both will probably increase with overgrazing. Other prominent species in this habitat type that tend to increase with overuse are Artemisia frigida, Danthonia parmi, Danthonia intermedia, and such forbs as Cerastium arvense, Achizlea millefolium, and Campanula rotundifolia. The palatable grasses, Festuca scabrella, Agropyron caninum, and Agropyron spicatum, generally decrease under heavy use. Festuca idahoensis, Koeleria cristata, and Helictotrichon hookeri tend to increase under moderate use, but will usually decrease under continued heavy grazing. Very likely the forbs Lupinus sericeus, Gaillardia aristata, Galium boreale, Senecio canus, and possibly Potentilla gracilis will decrease on heavily grazed sheep range, but increase on cattle range. Other species within this habitat type will likely respond to grazing as they do in the Festuca idahoensis series.

Range management.--Except for the presence of Potentilla fruticosa, this habitat type is similar to the grasslands in the Festuca scabrelza series. It is probably better suited for grazing by cattle and horses than by sheep since large tussock grasses produce most of the forage. The type can be grazed in late spring, summer, and early fall. The principal forage species within this type are expected to react to grazing as they do in the Festuca scabrelza series, and as discussed in the FESC/AGSP and FESC/FEID h.t. sections. However, Potentilla fruticosa will likely increase appreciably with overgrazing and complicate management. This shrub is normally not used to any extent by either livestock or big game. Appreciable use of the shrub usually is indicative of overgrazing, unless the range is on a rest-rotation management system. Although Potentilza fruticosa does not appear to be as aggressive as sagebrush, it is difficult to control for it sprouts readily following burning or spraying with $2,4-\mathrm{D}$.

\title{
Potentilla fruticosa /Festuca idahoensis h.t.
}

\author{
(POFR/FEID h.t.)
}

Distribution and environment.--This is an uncommon habitat type (fig. 21) found at elevations between 6,500 and $8,600 \mathrm{ft}(2,000$ and $2,600 \mathrm{~m})$ on the east side of the Continental Divide. It occurs primarily on gentle mountain slopes with moderately deep soils of granitic origin. Normally the soil surface is well covered with vegetation and litter. The type is considered moderately mesic, probably falling within the 20 - to $30-$ in $(50-$ to $75-\mathrm{cm})$ precipitation zone.

Vegetative composition.--Usually Potentilla fruticosa is the only shrubby species present. In some cases, however, Artemisia tridentata ssp. vaseyana or Artemisia cana are part of the community. Festuca idahoensis and Danthonia intermedia are the dominant graminoids; Carex obtusata may also be abundant. If present, Festuca scabrella and Agropyron spicatum are widely scattered. Achillea millefolium, Besseya wyomingensis, Arenaria congesta, Campanula rotundifolia, and Potentilia gracilis are the most common forbs (appendix E9). Geum triflorum is sometimes abundant. 

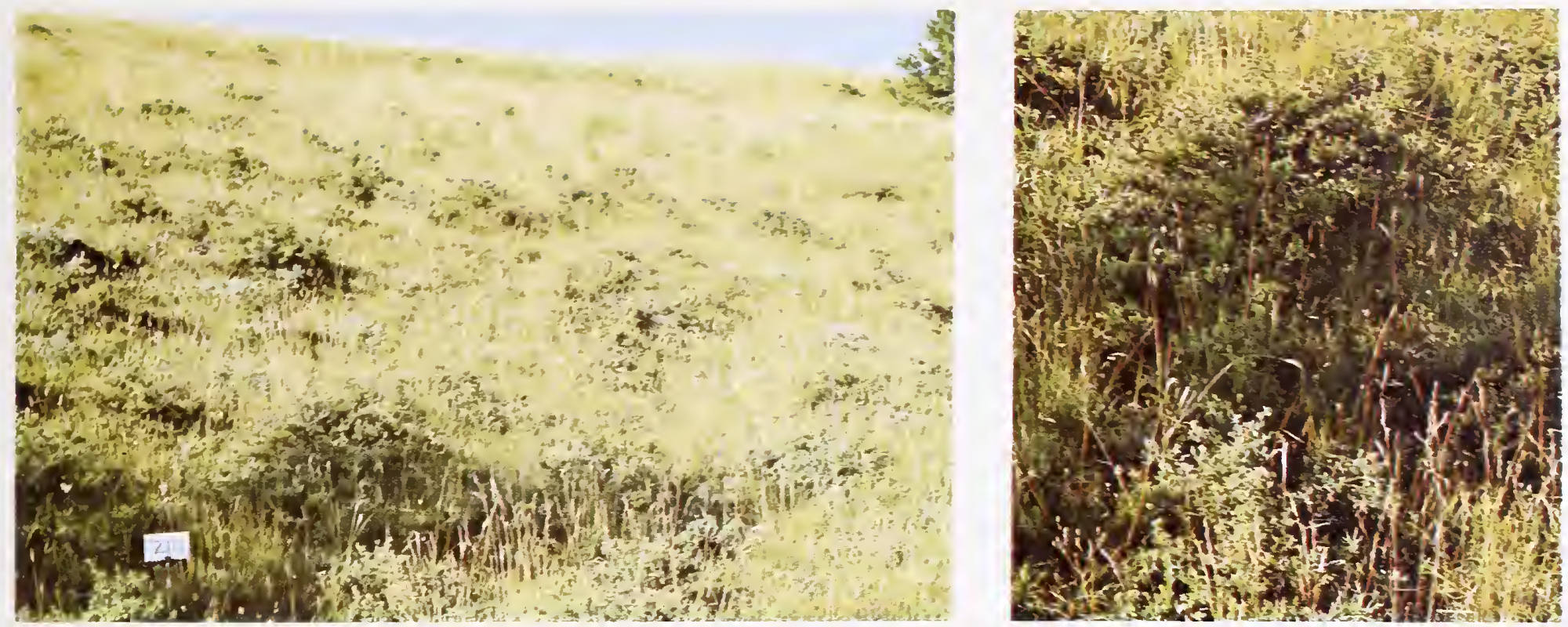

Figure 21.--Potentilla fmticosa/Festuca idahoensis h.t. at 7,240 ft elevation on a north exposure near Big Timber in south central Montana.

Productivity.--We did not measure plant production in this habitat type. The overall similarity between this type and the FEID/ACCA h.t. in species composition (with the exception of Potentilla fruticosa) and in environment suggests that total production probably is between 1,200 and $1,500 \mathrm{lb} / \mathrm{acre}(1,344$ and $1,680 \mathrm{~kg} / \mathrm{ha})$. Judging from our canopy-cover data (appendix E9), the unpalatable Potentizla fmiticosa averages less than 10 percent of the vegetation. Approximately 35 percent of the total consists of a mixture of forbs of generally low palatability. About 60 percent of the total vegetation usually consists of palatable grasses and sedges, the most productive of which are Festuca idahoensis and Danthonia intermedia.

Changes with grazing.--The primary species that decrease with overgrazing in the POER/FEID h.t. are Agropyron caninum, Festuca idahoensis and possibly Carex obtusata. Although the grasses Koelemia cristata and Danthonia intermedia may increase initially, they tend to decrease with continued heavy use. Potentilla fmuticosa, the only shrub of consequence, generally increases appreciably as do such forbs as Geum triflorum and Potentilla gracilis. Other species within this type probably respond to grazing as they do in the Festuca idahoensis series.

Range management.--Grazing in this type is generally confined to summer months since it usually occurs above $6,500-\mathrm{ft}(1,981-\mathrm{m})$ elevation. The type is about as well suited for cattle as it is for sheep. The herbaceous vegetation is expected to respond to grazing much as it does in the EEID/AGCA h.t. However, the presence of Potentilza fmiticosa may complicate management. This shrub fills a role somewhat similar to that of Artemisia tridentata in the ARTR/EEID h.t.; it is a relatively unpalatable woody plant that tends to increase with overgrazing. Although it does not appear to compete as aggressively as Artemisia tridentata, it is more difficult to control because of its ability to sprout following burning or spraying.

Noted elsewhere.--A vegetative type similar to the POFR/FEID h.t. but with Artemisia tridentata and Artemisia cana intermixed with Potentilla fruticosa in the overstory has been observed in Hayden Valley, Yellowstone National Park (D. C. Graham, personal communication). The POER/FEID h.t. has also been observed in northern Nevada, western Wyoming, and central Idaho (E. F. Schlatterer, personal communication). 


\title{
Purshia tridentata /Agropyron spicatum (MONT) h.t.
}

\author{
(PUTR/AGSP h.t.)
}

Distribution and environment.--The PUTR/AGSP h.t. (fig. 22) occupies rather extensive foothill areas in the Bitterroot Valley. Elsewhere it ordinarily is found as small patches, less than 20 acres ( $8 \mathrm{ha}$ ), in rather specialized environments. The type was observed only west of the Continental Divide. It occupies rather steep (40 to 75 percent) predominately southerly exposures at elevations ranging from 3,500 to 5,500 ft $(1,100$ to $1,700 \mathrm{~m})$. The soils of the stands we examined were dry, shallow, rocky, and predominately granitic in origin. Considerable rock and bare soil was exposed on the soil surface. This is a semiarid habitat type probably confined to the 10- to 15-in (25- to $40-\mathrm{cm})$ precipitation zone on sites with high evapotranspiration.
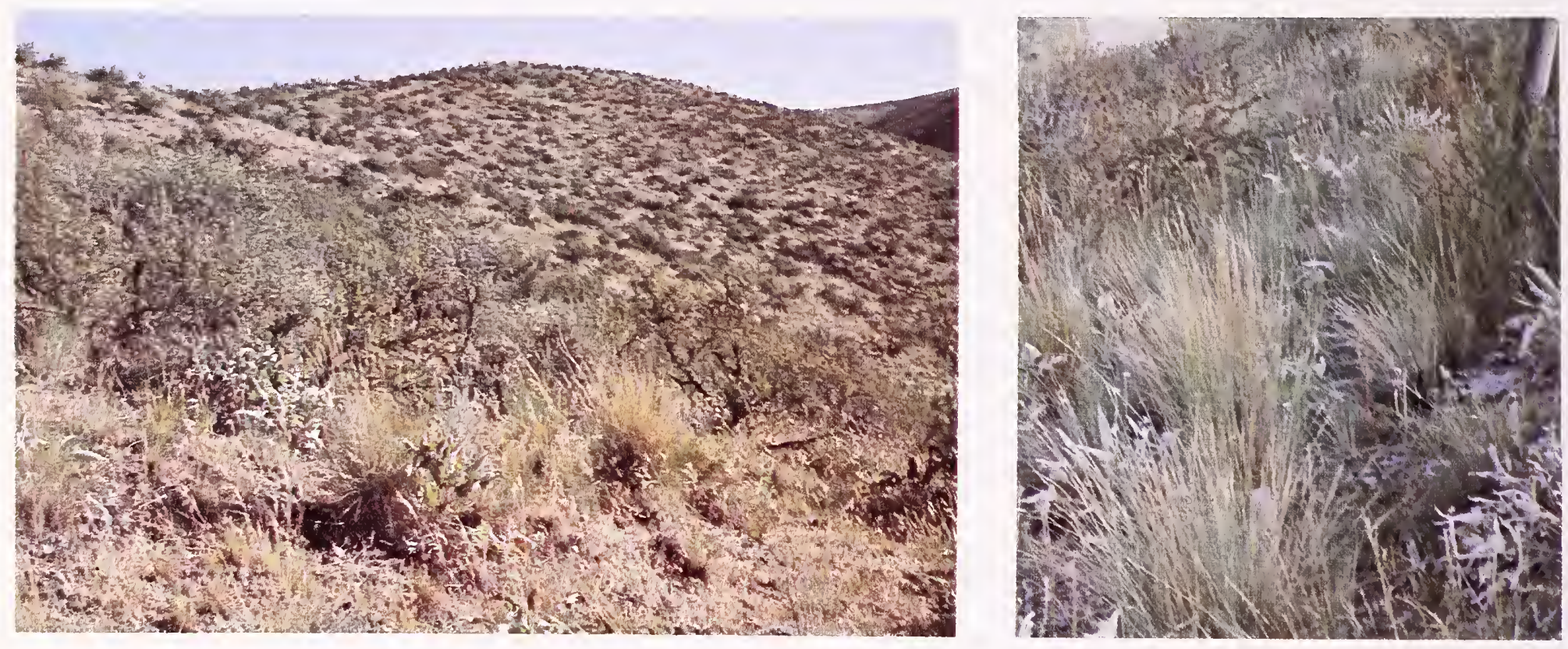

Figure 22.--Purshia tridentata/Agropyron spicatum h.t. in the Bitteroot Valley, elevation 4,200 ft, south of Darby. Usually this type does not occur in such extensive stands in Montana.

Vegetative composition.--The type is conspicuously dominated by Purshia tridentata which typically grows in somewhat open stands. Other medium-tall shrubs such as Chrysothamus nauseous and Chrysothamus viscidiflorus may be present, but seldom form a substantial part of the community. Agropyron spicatum is the predominant understory grass (appendix E10). KoeZeria cristata, Poa sandbergii, and Stipa comata may also be present. Both Festuca idahoensis and Festuca scabrella are lacking. Bromus tectorum is usually a conspicuous annual grass within the Purshia tridentata series. Balsamorhiza sagittata is often a dominant forb. Other common forbs include Chrysopsis vilzosa, Lupinus sericeus, Lithospermum ruderale, Tragopogon dubius, and Achillea millefolium.

Productivity.--Total production of vegetation appears to be similar to that in the ARTR/AGSP h.t., or about 700 to $800 \mathrm{lb} / \mathrm{acre}(784$ to $896 \mathrm{~kg} / \mathrm{ha})$. The amount of usable forage produced, however, probably exceeds that in the ARTR/AGSP h.t. because of a greater proportion of palatable species. The dominant shrub, Purshia tridentata, is a desirable browse species in contrast to the relatively unpalatable Artemisia tridentata. In addition, the palatable forb Balsamorhiza sagittata often occurs in abundance. Agropyron spicatum is the primary forage grass. 
Changes with grazing.--Most species within this habitat type will respond to grazing as they do in the Agropyron spicatum series. We can expect Agropyron spicatum to be the major decreaser under heavy cattle and horse use, and Balsamorhiza sagittata to be the major species to decrease under heavy spring and early summer sheep use. Chrysothamus viscidiflorus and Artemisia frigida usually increase with overgrazing, and Bromus tectorum will invade. In contrast to most shrubs, Purshia tridentata is palatable to all classes of livestock and especially to deer and elk in the fall and winter.

Range management.--Stands within the Purshia tridentata series occur primarily as scattered small patches on fairly steep slopes throughout the foothills of western Montana. These stands may be adjacent to or interspersed with ponderosa pine and Douglas-fir forests. Purshia tridentata is a key browse for big game; consequently, such stands may be very important winter range for deer and elk. Since Purshia tridentata is palatable to both cattle and sheep, livestock use of these areas should be permitted only if not in conflict with use by wildlife.

McConnel1 and Garrison (1966) found that summer utilization of Purshia tridentata is more detrimental than the same amount of winter use because carbohydrate reserves are at a low from May through July. Part of the energy demands by the tops as well as by the roots are drawn from root reserves in early to middle summer. McConnell and Smith (1977) determined that late summer and fall use is considerably less detrimental than spring and early summer use. Apparently summer browsing should be minimized if the resource manager wishes to maintain good productivity and reproduction of this shrub for wildlife use in winter.

Browse production appears to be stimulated when the shrubs are utilized to a moderate degree in the fall or winter. Garrison (1953) observed that clipping from 50 to 75 percent of the current growth of Purshia tridentata at this time caused greater twig growth the following year than if the shrubs were not clipped. He also found, however, that heavy clipping year after year eventually caused a decline in shrub vitality. McConnell and Smith (1977) observed that the longevity of this valuable browse species was reduced by heavy utilization. Garrison (1953) recommended that to sustain production of Purshia tridentata winter use on good sites should not exceed 60 to 65 percent and on poor sites 50 percent of the current growth.

Burning can be very detrimental to Purshia tridentata (Wright 1971). Even though sprouting may occur (Blaisdell and Mueggler 1956a), particularly if the soils are wet at the time of burning or shortly thereafter, recovery may take 10 years or longer (Blaisdel1 1953). Purshia tridentata is also severely injured by spraying with herbicides (Mueggler and Blaisdell 1958). Therefore considerable care should be exercised to avoid patches of Purshia tridentata where sagebrush control is part of the management strategy.

The understory species in the PUTR/AGSP h.t. are expected to respond to livestock use much as they do in the ARTR/AGSP h.t. The key species for spring-summer-fall grazing by cattle in this type is Agropyron spicatum. Management considerations for this major forage producer are discussed in the AGSP/BOGR h.t. section.

Noted elsewhere.--Daubenmire (1970) described a PUTR/AGSP h.t. that occurs only as scattered fragments in eastern Washington. The most notable species differences are the presence of Artemisia frigida and Chrysopsis vizlosa in the Montana type but not in the Washington type and the frequent lack of Eriogonum spp. which are common in the Washington type. 


\title{
Purshia tridentata /Festuca scabrella h.t.
}

\author{
(PUTR/FESC h.t.)
}

Distribution and environment.--The PUTR/FESC h.t. occurs principally west of the Continental Divide and north of $47^{\circ}$ latitude. The type appears topographically specific, as are the other habitat types within the Purshia tridentata series. It was observed in small patches on steep (more than 35 percent) southerly and easterly facing slopes, at elevations ranging from 3,000 to $5,000 \mathrm{ft}(900$ to $1,500 \mathrm{~m})$. The type is fairly arid, probably falling within the 12 - to $20-$ in $(30-$ to $50-\mathrm{cm})$ precipitation zone.

Vegetative composition.--The Purshia tridentata understory is predominated by grasses (fig. 23). Although Agropyron spicatum and Festuca idahoensis may be the most prevalent species, Festuca scabrella is a conspicuous and often abundant associate. Poa sandbergii and Koeleria cristata also are usually present. The annul grasses, Bromus tectomm and Festuca octoflora, comprise a conspicuous part of the understory. Balsamorhiza sagittata is commonly an abundant forb, with Achillea millefolium, Tragopogon dubius, Collinsia parviflora, and Lithosperum maderale frequent associates.
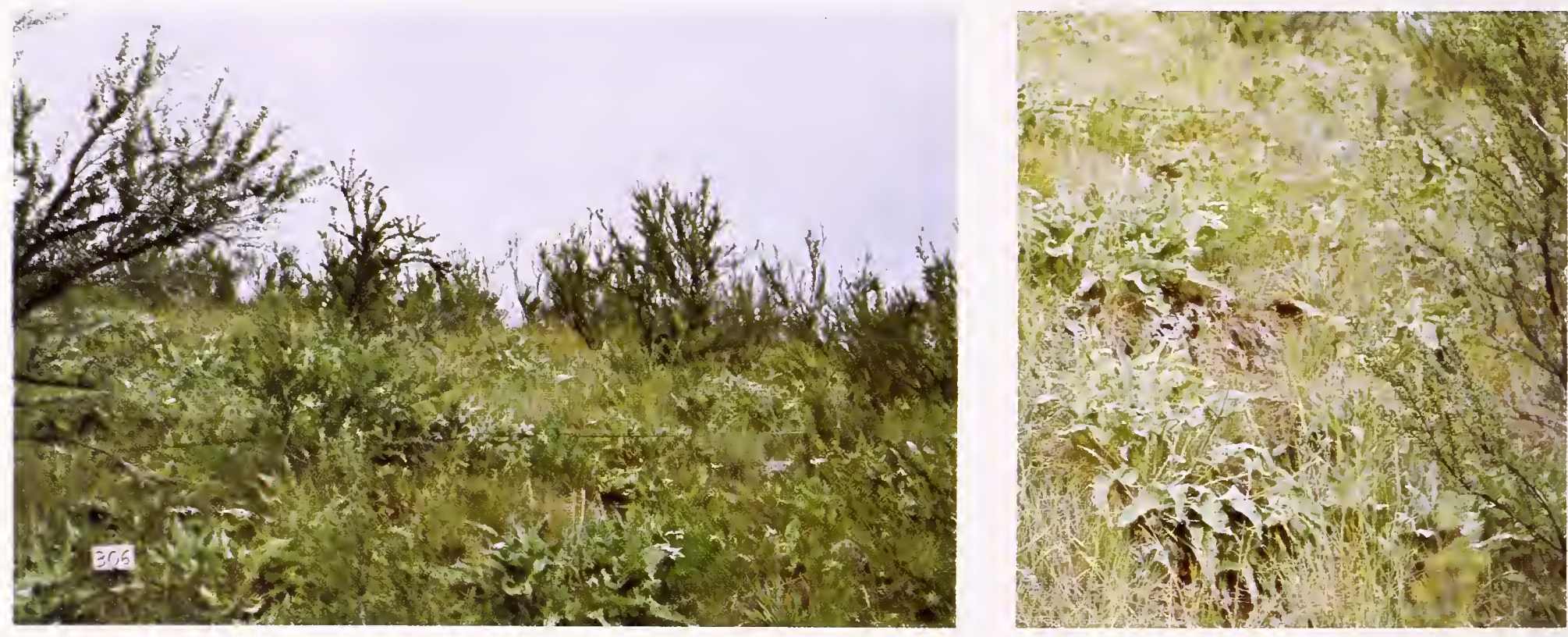

Figure 23.--Purshia tridentata/Festuca scabrella h.t. on a moderately steep southwest slope west of Flathead Lake in northwestern Montana.

Productivity.--We selected two stands within this habitat type to sample the range in site productivity. The good site produced about a third more total vegetation than the relatively poor site. Differences in production attributable to weather over a 3-year period amounted to almost 80 percent on the good site and more than 140 percent on the poor site. Average production over a 3-year period and a measure of yearly variability attributable to weather are presented in table 13. 
Table 13.--Extremes in production and variability over a 3-year period in the Purshia tridentata/Festuca scabrella habitat type

\begin{tabular}{|c|c|c|c|c|}
\hline \multirow[b]{2}{*}{ Growth form } & \multicolumn{2}{|c|}{ Stand 246} & \multicolumn{2}{|c|}{ Stand 306} \\
\hline & Average & SEl & Average & SE? \\
\hline & ----- & $--A i$ & --- & $-\ldots$ \\
\hline Graminoids & 407 & 114 & 431 & 41 \\
\hline Forbs & 379 & 89 & 542 & 146 \\
\hline Shrubs & 110 & 52 & 239 & 91 \\
\hline Tota1 & 897 & 251 & 1,212 & 200 \\
\hline
\end{tabular}

${ }^{1}$ Standard error over a 3 -year period.

2Multiply by 1.12 for $\mathrm{kg} / \mathrm{ha}$.

Shrubs, primarily the desirable browse Purshia tridentata, generally comprise less than 20 percent of the total annual vegetative production. Grasses and forbs form the remainder in about equal amounts. About two-thirds of the total forb production consists of Balsamorhiza sagittata, a desirable forage plant; the remainder of the forbs are of questionable forage value. The primary forage grasses are Agropyron spicatum, Festuca scabrella, and Festuca idahoensis. Therefore, forage plants of at least moderate palatability make up as much as 90 percent of the total production.

Changes with grazing.--Eestuca scabrella and Agropyron spicatum are the principal grasses in this type that decrease under heavy summer use by cattle and horses.

Festuca idahoensis, Koeleria cristata, and Poa sandbergii may increase initially, but they too will decrease with continued heavy use. Although Balsamorhiza sagittata may increase on cattle range, it decreases appreciably if heavily used by sheep in the spring and early summer. Purshia tridentata is a particularly desirable shrub on big game winter range. It is also palatable to sheep and cattle. Repeated heavy use of this valuable browse will cause it to decline. Bromus tectomum is the principal species to invade. Other species within the type probably respond to grazing as they do in the Eestuca scabrella series.

Range management.--As with the other habitat types within the Purshia tridentata series, the greatest value of the PUTR/FESC h.t. often will be as big game winter range. Purshia tridentata is the key browse species. Considerations related to its management are discussed in the PUTR/AGSP h.t. section. The understory vegetation is expected to respond to livestock grazing much as it does in the Festuca scabrella series. Key herbaceous species within the type are Festuca scabrella, Agropyron spicatum, Festuca idahoensis, and Balsamorhiza sagittata. Requirements of these species are discussed in the FESC/AGSP, AGSP/BOGR, AGSP/POSAN, and FEID/AGSP h.t. sections.

\title{
Purshia tridentata /Festuca idahoensis (MONT) h.t.
}

\author{
(PUTR/FEID h.t.)
}

Distribution and environment.--This habitat type (fig. 24) is seldom encountered in Montana. It may be found occasionally south of $47^{\circ}$ latitude west of the Divide on steep southerly exposures where moisture conditions are adequate to support Festuca idahoensis. The shallow, rocky soils are usually granitic in origin. It has been observed northeast of Deerlodge in small scattered patches at elevations above 5,000 ft $(1,500 \mathrm{~m})$. 


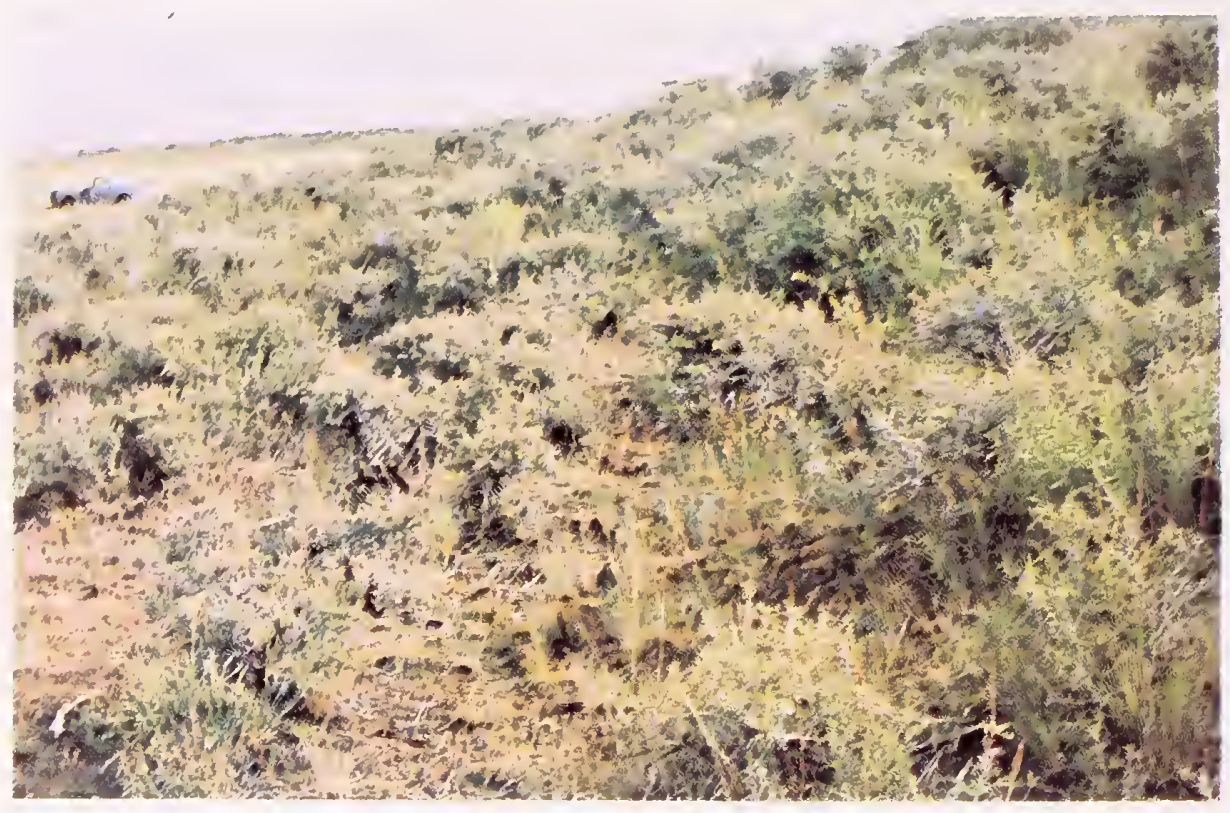

Figure 24.--Purshia tridentata/Festuca idahoensis h.t. on a moderate steep southwest exposure northeast of Deer Lodge. The bitterbrush has been heavily browsed by deer in the winter.

Vegetative composition.--The PUTR/FEID h.t. is delineated from the PUTR/AGSP h.t. by the presence of Festuca idahoensis, and from the PUTR/FESC h.t. by the absence of Festuca scabrella. Agropyron spicatum is usually the dominant grass, but Festuca idahoensis is conspicuously present, along with Koeleria cristata and Poa sandbergii. Arenaria congesta, Phlox hoodii, Eriogonum umbellatum, and Lupinus sericeus are among the more abundant forbs.

Productivity.--Total vegetal production in the PUTR/FEID h.t. probably appraoches that in the PUTR/FESC h.t., or approximately 800 to $1,000 \mathrm{lb} /$ acre $(896$ to $1,120 \mathrm{~kg} / \mathrm{ha})$. Perhaps as much as 75 percent of the production is composed of desirable forage species. The primary forage grasses are Agropyron spicatum, Festuca idhaoensis, Koeleria cristata, and Poa sandbergii. The palatable Purshia tridentata is the primary shrub. The forbs are of questionable value as forage.

Changes with grazing.--The PUTR/FEID h.t. is particularly valuable as big game winter range, as are the other types within the Purshia tridentata series. Purshia tridentata is palatable to both big game and livestock. If used heavily and repeatedly, it will decline in vigor. Heavy spring or summer use will cause Agropyron spicatum, Festuca idahoensis, and Stipa viridulal to decline as well. Poa sandbergii and Koeleria cristata may increase initially, but are likely to decrease with continued heavy use. Such unpalatable species as Chrysopsis villosa, Artemisia frigida, and Phlox hoodii increase with overgrazing and Bromus tectorum tends to invade. Other species within this habitat type probably will respond to grazing as they do in the Festuca idahoensis series.

Range management.--The primary use of this uncommon habitat type most often will be as big-game winter range. Management considerations for the major browse, Purshia tridentata, are discussed in the PUTR/AGSP h.t. section. Livestock grazing should be permitted only when not in conflict with game use. Requirements of the major herbaceous forage species, Agropryon spicatum and Festuca idahoensis, are discussed in the $A G P S / B O G R$ and FEID/AGSP h.t. sections. 
Noted elsewhere.--Vegetation similar to our PUTR/EEID h.t. occurs at least in Oregon and Washington. Franklin and Dyrness (1969) identified a Purshia tridentata-Festuca idahoensis community, and Hall (1973) a Purshia tridentata--Agropyron--Festuca community-type for central and eastern Oregon. Daubenmire described a PUTR/FEID h.t. for eastern Washington that differs principally in its greater abundance of annuals than in our Montana type.

\title{
Cercocarpus ledifolius /Agropyron spicatum h.t.
}

\author{
(CELE/AGSP h.t.)
}

Distribution and environment.--The CELE/AGSP h.t.is similar in many ways to habitat types within the Purshia tmidentata series. These types usually occur as rather small patches of only a few acres, they are generally restricted to rather dry, rocky, southerly exposures, and they have a high potential for being very important winter habitat for big game. The stands we examined occurred on limestone outcrops, but we suspect the type is not confined to this material. They were found at elevations from 4,500 to 6,800 ft $(1,400$ to $2,100 \mathrm{~m})$ in southwestern Montana. The soils were shallow and very rocky, and the slopes usually steep (up to 100 percent).

Vegetative composition.--Cercocarpus ledifolius obviously dominates this type (fig. 25), but species of Artemisia, Chrysothamns, and Juniperus may also be present. In some cases, Cercocarpus ledifolius can be more than $10 \mathrm{ft}(3 \mathrm{~m})$ tall, but more commonly it ranges in height from 5 to $8 \mathrm{ft}(1.5$ to $2.5 \mathrm{~m})$. Usually it occurs in rather open stands with sparse herbaceous understory and considerable bare soil. Such low shrubs as Artemisia frigida and Gutierrezia sarothrae are common. The herbaceous cover consists primarily of Agropyron spicatum, but Stipa comata, Oryzopsis hymenoides, and Koeleria cristata are often present as well (appendix Ell1).

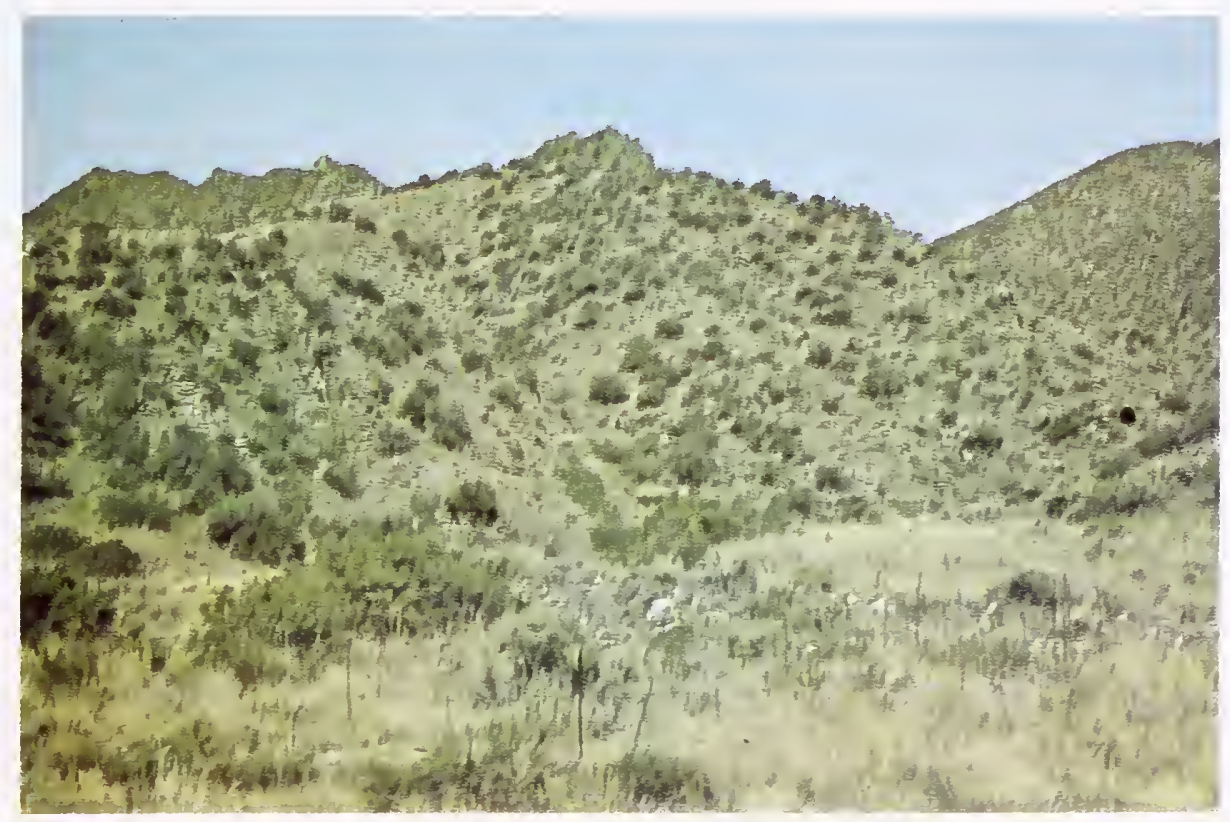

Figure 25.-Cercocarpus Zedifolius/Agropyron spicatum h.t. steep limestone slopes near the Lewis and Clark Caverns in southwestern Montana. 
Productivity.--Production data for this habitat type in Montana are not available. In central Idaho, however, Schlatterer (1972) reported a wide range in total productivity--from 500 to $1,500 \mathrm{lb} /$ acre $(560$ to $1,680 \mathrm{~kg} / \mathrm{ha}$ ). We believe production of most of our western Montana stands probably will not exceed about $800 \mathrm{lb} / \mathrm{acre}(896 \mathrm{~kg} / \mathrm{ha})$. Most of the forage is produced by Agropyron spicatum, Stipa comata, and Cercocarpus ledifolius.

Changes with grazing.--The principal shrub, Cercocarpus Zedifolius, is highly palatable to big game in the winter. It is only moderately palatable to sheep and cattle. Repeated heavy utilization in the winter may cause a decrease in reproduction and vigor of the smaller Cercocarpus plants which are entirely within reach of the animals. Heavy summer grazing ordinarily causes a decrease in Agropyron spicatum and Oryzopsis hymenoides; the unpalatable shrubs, Artemisia tridentata, Artemisia frigida, and Gutierrezia sarothrae, usually increase. Such forbs as Erigeron caespitosa and Phlox hoodii may also increase conspicuously. Stipa comata and Koeleria cristata may increase initially under heavy grazing, but continued overuse will cause these two grasses to decline. Other species within the habitat type probably respond to grazing as they do in the Agropyron spicatum series.

Range management.--The primary value of the CELE/AGSP h.t. in western Montana is as big-game winter range. Cercocarpus ledifolius is a preferred winter browse for both deer and elk. The type is relatively poor livestock range. Cercocarpus ledifolius is not very palatable to either cattle or sheep in the summer, and the type usually occurs on rather steep, rocky slopes not readily accessible to livestock. Consequently, conflicts in use between livestock and wildlife are unlikely except on those sites low enough in elevation to be used by livestock in the winter.

Cercocampus ledifolius appears to respond to use similarly to Purshia tridentata as described in the PUTR/AGSP h.t. section. In Utah, fall clipping of all current growth of Cercocarpus Zedifolius reduced subsequent twig growth; however, utilization to a level where 1 to 2.5 in $(2.5$ to $6.4 \mathrm{~cm})$ of current twigs remained actually stimulated production the following year compared to unclipped plants (E1lison 1960). To maintain productivity of this valuable shrub, Garrison (1953) recommends that winter utilization of current growth that is within reach of the animals not exceed 50 to 60 percent. Little available browse is produced once the plant tops have grown beyond normal grazing height. In such cases, top pruning may improve browse availability (Thompson 1970).

Noted elsewhere.--Schlatterer (1972) described a Cercocarpus Zedifolius--Agropyron spicatum community-type and Lewis (1975) a CELE/AGSP h.t. associated with limestone soils in central Idaho and northern Nevada. They appear somewhat more mesic than the Montana type in that they contain Symphoricarpos oreophilis but not Artemisia frigida, Gutierrezia sarothrae, and Stipa comata. Scheldt and Tisdale (1970) indicate that a Cercocarpus ledifolius type with Agropyron spicatum as the principal understory species is scattered across central and southern Idaho. However, they did not find the type confined to limestone soils. A Cercocarpus ledifolius-grass community type that occurs on lavas was described by Hall (1973) for eastern Oregon. This type differs considerably from the Montana type in that it may contain Carex geyerii, Calamagrostis mbescens, and Festuca idahoensis. 


\title{
Rhus trilobata /Agropyron spicatum h.t.
}

\author{
(RHTR/AGSP h.t.)
}

Distribution and environment.--Habitat types within the Rhus trizobata series are found primarily along southerly and westerly facing low-elevation breaks into tributaries of the Missouri River. The type commonly occurs as patches or strips (fig. 26) on the convex shoulders and slopes that descend from the sedimentary benchlands or terraces above the rivers and streams. All stands we observed were below 4,500 ft $(1,400 \mathrm{~m})$ elevation. The soils are typically shallow, rocky, and usually of sandstone parent material. Ordinarily, considerable amounts of rock and bare soil are exposed on the soil surface (appendix D). This is considered a fairly arid vegetation series. The RHTR/AGSP h.t. is the predominant type within the series.
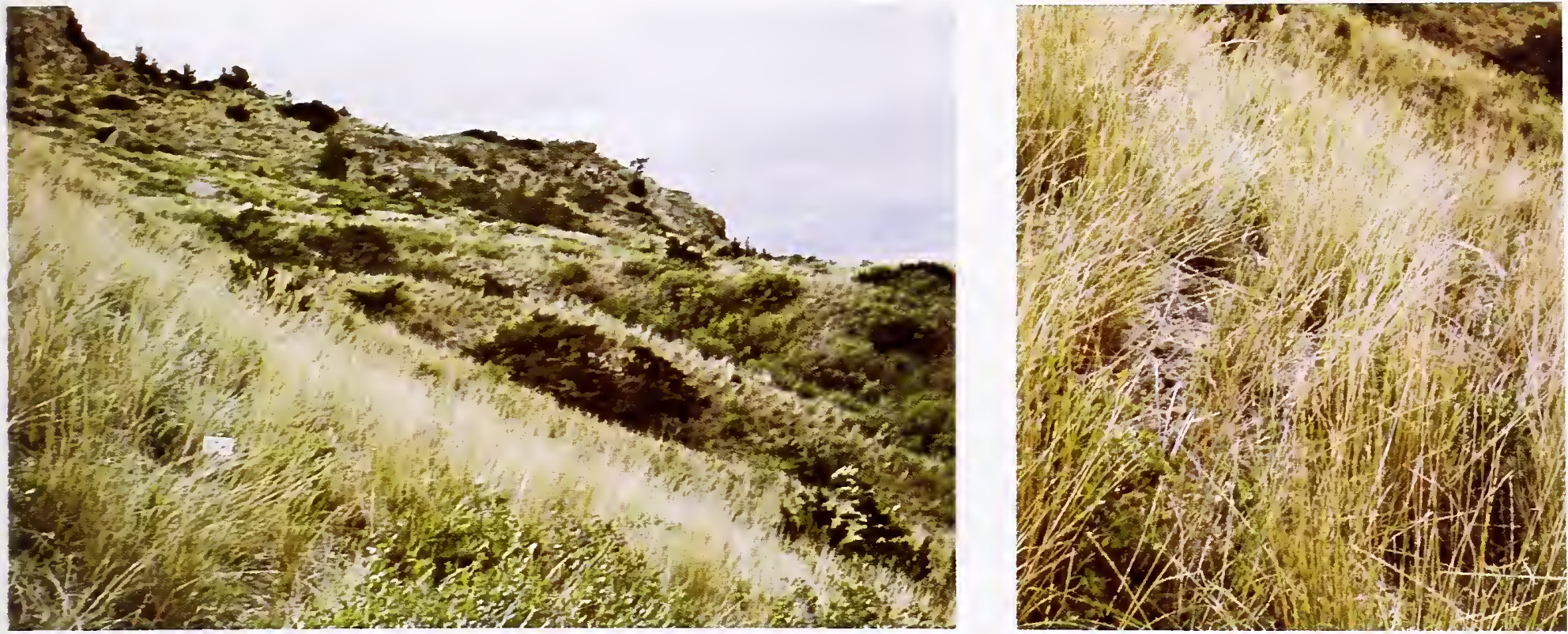

Figure 26.--Rhus triZobata/Agropyron spicatum h.t. on a moderately steep south slope along the Yellowstone River near Big Timber in south central Montana.

Vegetative composition.--The shrubby Rhus trilobata overstory is accompanied by a predominantly Agropyron spicatum understory. The amount of Rhus trilobata varies considerably from only 1 or 2 percent canopy cover to well over 25 percent. A variety of other shrubs such as Chrysothamns spp., Artemisia tridentata, Ribes cereum, and even Pmuns virginiana and Amelanchier alnifolia may be associated with Rhus trilobata (appendix E12), but they are seldom abundant. Opuntia polyacantha and Artemisia frigida are the most common low shrubs. Agropyron spicatum, the most abundant grass, may be accompanied in some cases by substantial amounts of either Oryzopsis hymenoides or Agropyron smithii. Broms tectorum is commonly an abundant annual. The more conspicuous forbs are Vicia americana, Chrysopsis villosa, Achillea millefolium, and Sphaeralcea coccinea.

Productivity.--We did not sample this habitat type for herbage production. Very likely, however, it will produce about as much as either the $A G S P / B O G R$ h.t. or the AGSP/AGSM h.t., between 500 and $700 \mathrm{lb} / \mathrm{acre}(560$ and $784 \mathrm{~kg} / \mathrm{ha}$ ). Judging from our canopy-cover data (appendix E12), approximately half of this production will consist of forage grasses, about a third will be shrubs, and the remainder will be forbs. The forbs and shrubs are of little forage value. 
Changes with grazing.--Heavy summer use of the type by livestock usually causes a decrease in the amount of Agropyron spicatum and Orhyzopsis hymenoides, and an increase in Chrysothamnus nauseosus, opuntia polyacantha, Chrysopsis villosa, and possibly Rhus trilobata. These low-1ying river bank areas are often deer winter range. Repeated heavy winter use by big game will cause a decline in Prunus virginiana and possibly Rhus trilobata. Bromus tectorum is the principal species that invades with overgrazing.

Range management.--This type is generally more valuable for wildlife habitat than for livestock range. It occurs primarily as stringers along river breaks and receives considerable use by deer in the winter, especially if other browse is limited. Its major shrub, Rhus trilobata, however, is low in palatability for livestock. The greatest value of the type for livestock would be for early spring or late fall grazing. Agropyron spicatum is the key forage species for livestock. Management considerations for this grass are discussed in the AGSP/BOGR h.t. section.

\title{
Rhus trilobata /Festuca idahoensis h.t.
}

\author{
(RHTR/FEID h.t.)
}

Distribution and environment.--This infrequent type occurs primarily as patches or strips on the convex shoulders and slopes that drop off from the sedimentary benchlands or terraces above tributaries of the Yellowstone and Missouri Rivers (fig. 27). The stands we observed were below $4,500 \mathrm{ft}(1,400 \mathrm{~m})$ elevation. Soils are typically shallow, rocky, and usually of sandstone parent material. Considerable rock and bare soil are commonly exposed on the soil surface (appendix D). The RHTR/FEID h.t. is slightly less arid than the RHTR/AGSP h.t.
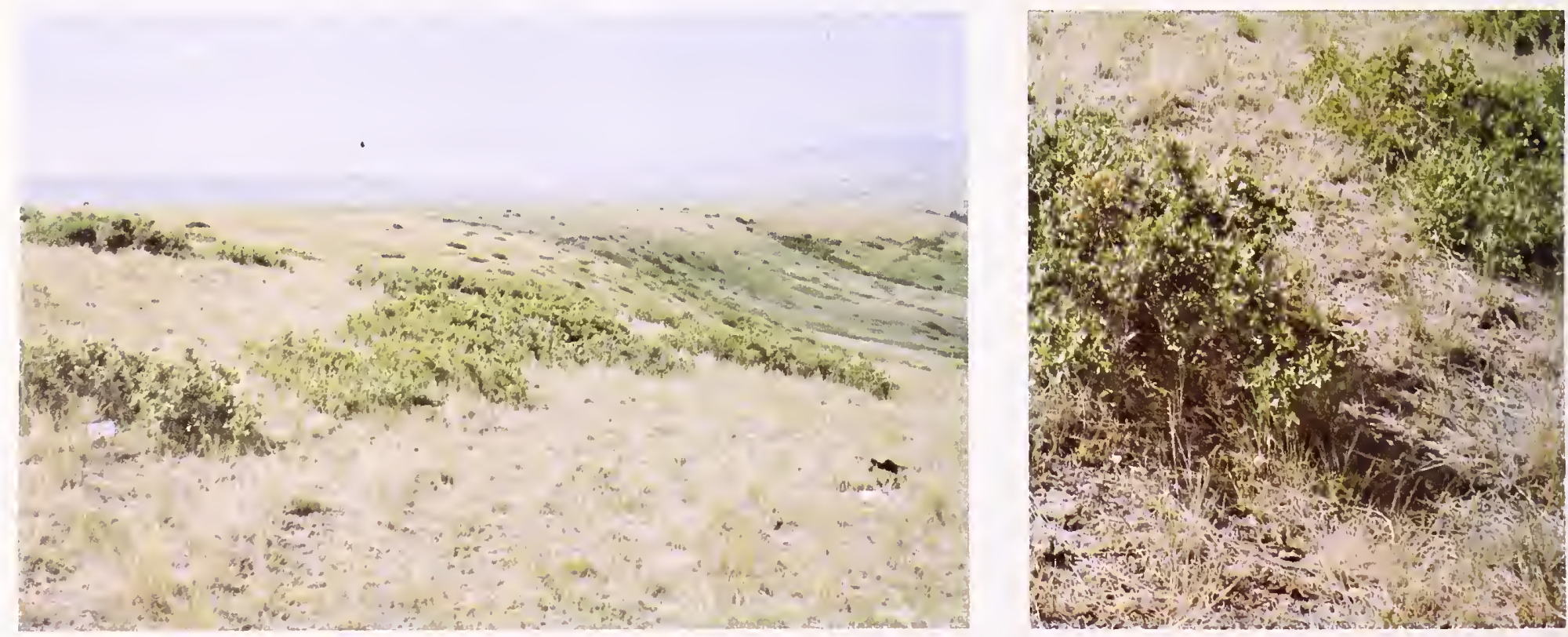

Figure 27.--Rhus trilobata/Festuca idahoensis h.t. along the shoulder of benches dropping into the Missouri River southwest of Great Falls, Montana. 
Vegetative composition.--The presence of Festuca idahoensis, even though Aropyron spicatum may be more abundant, characterizes this habitat type. Bouteloua gracitis, Stipa comata, and Carex pennsylvanica were other conspicuous graminoids in the example of this type sampled (appendix E12). Chrysopsis vizlosa, Achizlea mizlefolium, Cerastium arvense, and Phlox hoodii were the most abundant forbs.

Productivity.--Total production in the RHTR/FEID h.t. probably is slightly greater than in the RHTR/AGSP h.t., or about 600 to $800 \mathrm{lb} / \mathrm{acre}(672$ to $896 \mathrm{~kg} / \mathrm{ha})$. Canopycover data (appendix E12) suggest that about half of the production consists of palatable graminoids, about a fourth shrubs, and the remainder forbs. Neither the shrubs nor forbs contribute much to forage production since they consist primarily of species low in palatability.

Changes with grazing.--The principal forage grasses that probably decline with continued heavy summer use of this type are Agropyron spicatum, Festuca idahoensis, and Stipa comata. Species that usually increase are Chrysopsis villosa, Artemisia frigida, Achillea millefolium, and Cerastium arvense. Continued overgrazing by livestock may cause Rhus trilobata to increase; however, repeated heavy winter use by big game may cause this shrub to decline. Bromus tectorum frequently invades with overgrazing or where rodent disturbance exists.

Range management.--As with the RHTR/AGSP h.t., this uncommon and rather isolated type probably has greatest value as wildlife habitat. Although not highly palatable, Rhus trizobata may receive considerable use by deer in the winter where winter range is limited. Probably the greatest value to livestock would be as small areas of spring-fall range. Management implications for the principal livestock forage species, Agropyron spicatum and Festuca idaheonsis, are discussed in the AGSP/BOGR and FEID/AGSP h.t. sections.

\title{
Sarcobatus vermiculatus /Agropyron smithii h.t.
}

\author{
(SAVE/AGSM h.t.)
}

Distribution and environment.--The Sarcobatus vermiculatus series is most commonly encountered as narrow bands along the flood plains of rivers and streams in low precipitation areas throughout the western part of the State. We also have seen it in rather broad expanses along flat lakeshores and playas in north central Montana. Sarcobatus vermiculatus typically grows on heavy, poorly drained saline or alkaline soils.

Vegetative composition.--Although Sarcobatus vermiculatus is the dominant shrub in this type (fig. 28), Atriplex nuttallii and Chrysothammus viscidiflorus may also be present. Canopy cover of Sarcobatus vermiculatus may be low (less than 10 percent), yet the stature of the plant compared to associated vegetation creates a shrubby aspect. Agropyron smithii is the dominant understory species. Bouteloua gracilis, Stipa comata, Artemisia frigida, and Opuntia polyacantha may also be present, but forbs are characteristically scarce. This series contains fewer plant species (floristically poorer) than any of the other grassland or shrubland series described.

Productivity.--We did not sample this type for production. However, judging from our canopy-cover data (appendix E13), perhaps as much as two-thirds of the vegetation consists of such palatable grasses as Agropyron smithii and Poa juncifolia. With the exception of Atriplex nuttalii, shrubs and forbs do not contribute appreciably to forage production. 

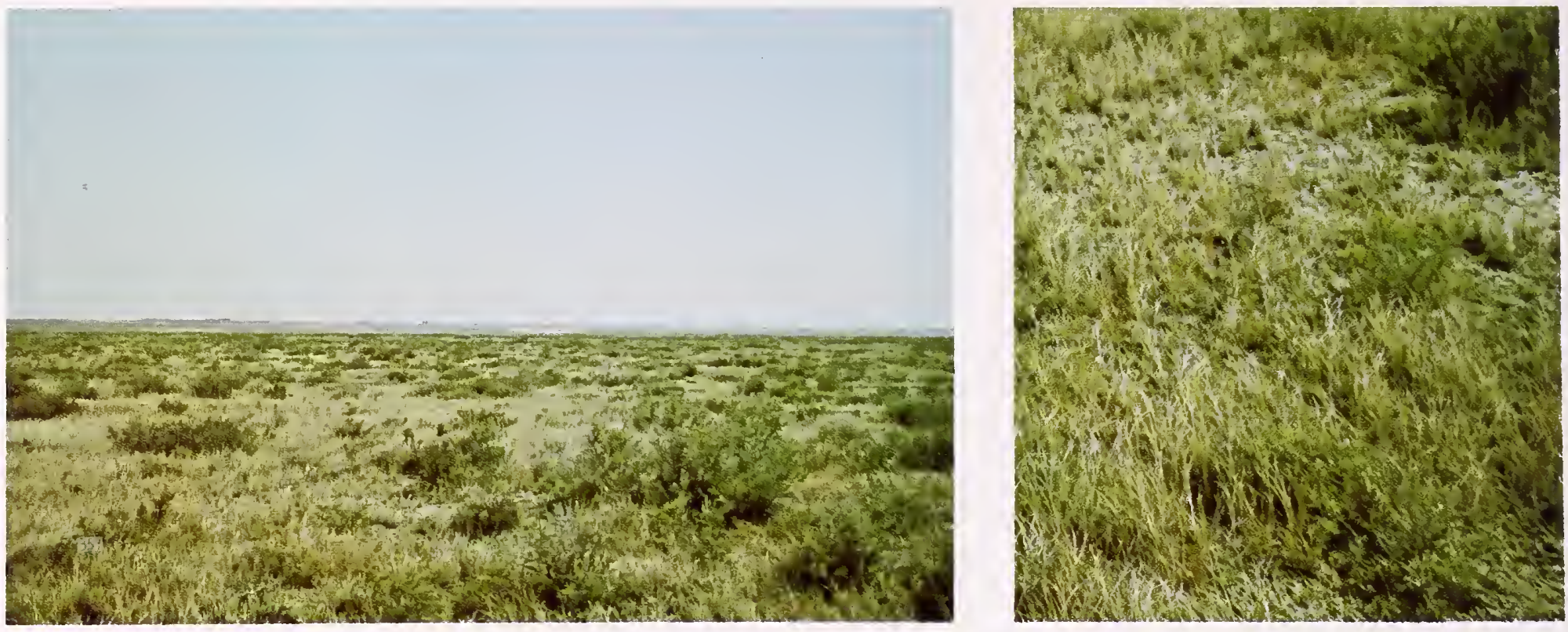

Figure 28.--Sarcobatus vermiculatus/Agropyron smithii h.t. on alkaline flats west of Great Falls.

Changes with grazing.--Agropyron smithii, Poa juncifolia, Stipa comata, and Atriplex nuttallii can be expected to decrease with continued overgrazing of this type. Very likely Sarcobatus vermiculatus, Opuntia polyacantha, and Artemisia frigida will be the principal species that increase. Bouteloua gracilis may also increase since its low growth form enables it to withstand grazing.

Range management.--Although not very palatable, Sarcobatus vermiculatus may be browsed somewhat by cattle, deer, and antelope in the winter. This shrub is poisonous to sheep and the type is not desirable sheep range. The valley-bottom location makes the type best suited for late fall, winter, and early spring cattle range. Management of the principal forage species, Agropyron smithii, is discussed in the AGSP/AGSM h.t. section. This rhizomatous grass is able to withstand heavy fall and winter use; greater care must be taken with spring use.

\title{
Sarcobatus vermiculatus /Elymus cinereus h.t.
}

\author{
(SAVE/ELCI h.t.)
}

Distribution and environment.--The SAVE/ELCI h.t. (fig. 29) occurs primarily as a rather narrow band along the flood plains of rivers and streams in low precipitation areas throughout the western part of the State. Sarcobatus vermiculatus typically grows on heavy, poorly drained saline or alkaline soils. The environmental differences between this and the SAVE/AGRM h.t. are uncertain. The SAVE/ELCI h.t. appears to occur more on the concave toe slopes where the soils may be better drained and less saline than they are on the flat.

Vegetative composition.--The presence of clumps of Elymus cinereus differentiates the SAVE/ELCI h.t. from the SAVE/AGSM h.t. Agropyron smithii is usually abundant beneath the Sarcobatus vermiculatus overstory; such graminoids as Agropyron spicatum, Koeleria cristata, and Carex filifolia may also be present. Forbs, such as Aster chilensis, Iva axillaris, and Sphaeralcea coccinea, occur more commonly here than in the SAVE/AGSM h.t. 


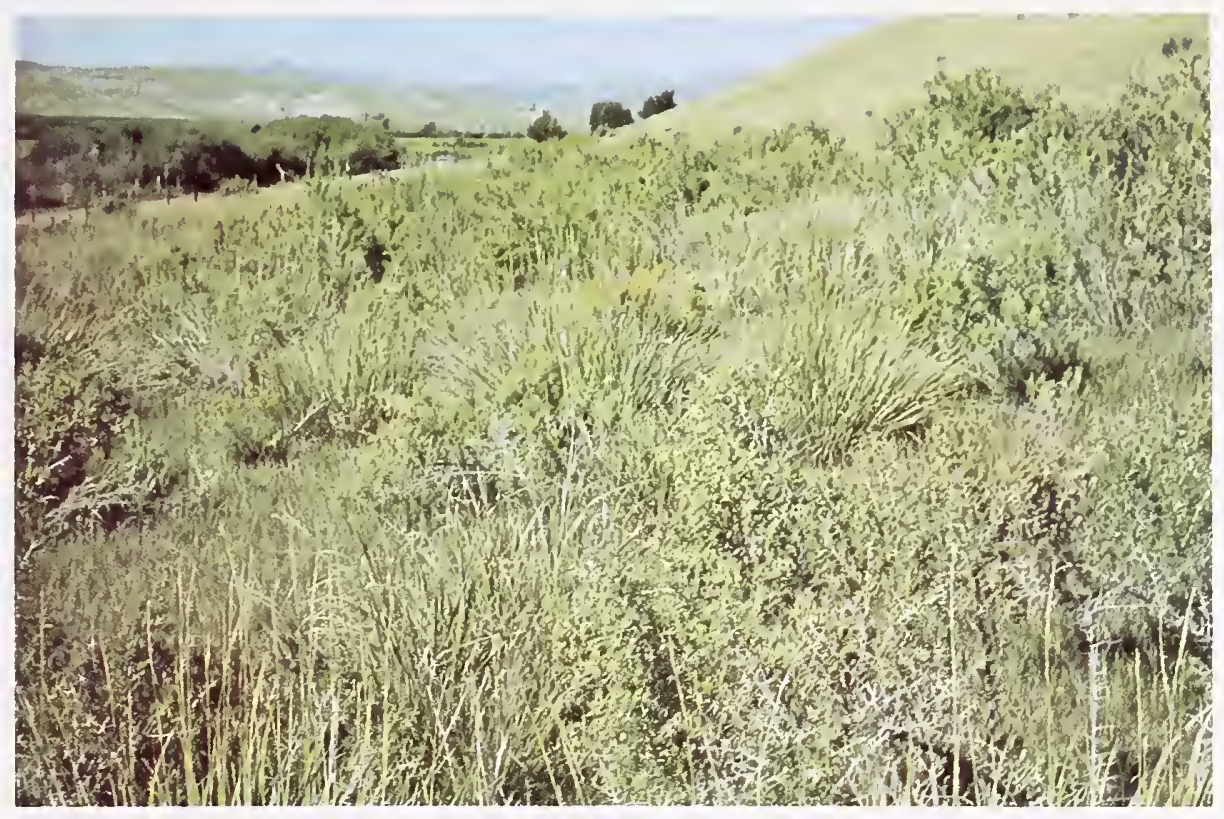

Figure 29.--Sarcobatus vermiculatus/Elymus cinereus h.t. on toe clopes into the Ruby River south of Alder in southwestern Montana.

Productivity.--We did not measure total production in this type. Our canopy-cover data (appendix E13) suggest that at least half of the production consists of such palatable grasses as Agropyron smithii and Agropyron spicatum. Neither the shrubs nor forbs are valued forage.

Changes with grazing.--Overgrazing of this type commonly causes Agropyron spicatum and Agropyron smithii to decline. If heavy use persists, Koeleria cristata, Elymus cinereus, and possibly Chrysothamnus viscidifloms will probably decrease as well. The principal species that increase are Sarcobatus vermiculatus, Gutierrezia sarothrae, and Opuntia polyacantha.

Range management.--Sarcobatus vermiculatus is used somewhat by cattle, deer, and antelope in the winter but is poisonous to sheep. Best use of this low-elevation type probably is as late fall, winter, and early spring cattle range. Agropyron smithii and Agropyron spicatum are principal forage producers. Management considerations for these two grasses are discussed in the AGSP/BOGR and AGSP/AGSM h.t. sections. Elymus cinereus may also be an important forage producer. Krall and others (1971) found that early spring grazing is very harmful to this grass. They suggest that no more than 50 percent of the herbage of Elymus cinereus be grazed prior to its boot stage of development, and that spring grazing not take place every year.

\section{OTHER VEGETATION TYPES}

What appear to be climax shrubland and grassland communities that do not fit our classification were occasionally encountered in western Montana. We suspect that some of these represent scarce but valid habitat types. 
Foremost among these suspect habitat types is a shrub community in southwestern Montana dominated by Artemisia cana. This type occurs on deep, loamy, alluvial soils along some mountain streams at elevations usually over $6,000 \mathrm{ft}(1,827 \mathrm{~m})$. It has been observed as rather small patches less than 5 acres ( 2 ha) in size in and near Yellowstone National Park. Artemisia tridentata ssp. vaseyana may be intermixed with the dominant Artemisia cana. The grass-forb understory is similar to that found in the more moist portions of the ARTR/FEID h.t. The type probably should be designated as an Artemisia cana/Festuca idahoensis h.t. (ARCA/FEID h.t.). Schlatterer (1972) described a somewhat similar ARCA/FEID community that occurs on depositional soils in the Sawtooth Mountains of central Idaho.

At least two other sagebrush habitat types probably occur in southwestern Montana on dry, alkaline, alluvial soils. One is dominated by Artemisia Zongizoba and the other by Artemisia pedatifida (Morris and others 1976). Both of these relatively uncommon species are dwarfed shrubs; the latter is a subshrub 4 to 6 in (10 to $15 \mathrm{~cm}$ ) high. The primary herbaceous associates appear to be Agropyron spicatum and Festuca idahoensis. Both Artemisia Zongiloba/Agropyron spicatum and Artemisia Zongizobal Festuca idahoensis (ARLO/FEID) communities are reported to occur in central Idaho (Schlatterer 1972; Tisdale and others 1965), and an ARLO/FEID h.t. in northern Nevada (Zamora and Tueller 1973). Very likely we have an ARLO/FEID h.t. in southwestern Montana as we11. We also observed a single example of what appears to be an Artemisia pedatifida/Festuca idahoensis h.t. in Beaverhead County near Bannock Pass.

Although we have listed only the SAVE/AGSM and SAVE/ELCI habitat types in the Sarcobatus vermiculatus series, very likely a third type exists in which Distichlis stricta is the principal understory. Daubenmire (1970) reported a Sarcobatus vermiculatus/Distichlis stricta (SAVE/DIST) h.t. for eastern Washington. Based on our own observations and reports from others, we believe a SAVE/DIST h.t. may also occur in western Montana.

Communities dominated by Elymus cinereus occur occasionally in western Montana, generally as small patches on saline-alkaline soils along low-elevation streambanks. However, in Lake County approximately 6 miles $(10 \mathrm{~km})$ west of Polson, this grass dominates extensive areas of a broad valley. In this stand, Agropyron smithii and Puccinellia distans were the most common associates; a few widely scattered Chrysothammus nauseosus shrubs a1so occurred. Quite possibly an Elymus cinereus/Agropyron smithii h.t. would be a valid type for western Montana.

Composition of the grassland and shrubland vegetation of the Pryor Mountains in south central Montana is somewhat different from that in the rest of western Montana. This may be attributable to the occurrence of species affiliated with flora of the Central Rocky Mountains. Our sampling of the Pryor Mountain vegetation was not adequate to define many of these differences. An example was encountered on East Pryor Mountain at an elevation of approximately $8,500 \mathrm{ft}(2,600 \mathrm{~m})$ where extensive areas were dominated by Carex scirpoides (40 percent canopy cover) and Festuca idahoensis (10 percent canopy cover). Twenty-seven different forbs were encountered, the most abundant of which were Phiox hoodii and Geum triflomm. Extensive sheep grazing in the past may have significantly altered composition of vegetation on this area to preclude identifying it with previously described habitat types. On the other hand, if the vegetation has not been appreciably altered, this type may represent a valid Festuca idahoensis/Carex scirpoides h.t.

We did not attempt to classify the vegetation occurring along the relatively narrow riparian zones. Such stringers of willows and sedges along the edges of streams and marshes do not occupy much area but are critical for stream channel stabilization and fisheries. Riparian vegetation merits intensive, separate study. 


\section{PUBLICATIONS CITED}

Anderson, E. W.

1956. Some soil-plant relationships in eastern Oregon. J. Range Manage. 9(4):171175 .

Beals, Edward W.

1973. Ordination: Mathematical elegance and ecological naiveté. J. Ecol. $61(1): 23-35$.

Beath, 0. A., and J. W. Hamilton.

1952. Chemical composition of Wyoming forage plants. Univ. Wyo. Agric. Exp. Stn. Bul1. $311,40 \mathrm{p}$.

Beetle, A. A.

1960. A study of sagebrush. The section Tridentata of Artemisia. Univ. Wyo. Agric. Exp. Stn. Bull. 368, $83 \mathrm{p}$.

Beetle, A. A., W. M. Johnson, W. M. Lang, R. L. Lang, M. May, and D. R. Smith. 1961. Effect of grazing intensity on cattle weights and vegetation of the Bighorn experimental pastures. Univ. Wyo. Agric. Exp. Stn. Bull. 373, 23 p.

Blaisde11, J. P.

1949. Competition between sagebrush seedlings and reseeded grasses. Ecology $30(4): 512-519$.

Blaisdel1, J. P.

1953. Ecological effects of planned burning of sagebrush-grass range on the Upper

Snake River Plains. U.S. Dep. Agric., Tech. Bull. 1075, 39 p.

Blaisdel1, J. P., and W. F. Mueggler.

1956a. Sprouting of bitterbrush (Purshia tridentata) following burning or top removal. Ecology $37(2): 365-369$.

Blaisdell, J. P., and W. F. Mueggler.

1956b. Effects of 2,4-D on forbs and shrubs associated with big sagebrush. J. Range Manage. $9(1): 38-40$.

Blaisdel1, J. P., and J. F. Pechanec.

1949. Effects of herbage removal at various dates on vigor of bluebunch wheatgrass and amount of balsamroot. Ecology 30(3):298-305.

Booth, W. E.

1972. Grasses of Montana. Dep. Bot. and Microbiol., Mont. State Univ., Bozeman, 64 p. Booth, W. E., and J. C. Wright.

1966. Flora of Montana. Part II. Dep. Bot. and Microbiol., Mont. State Univ., Bozeman, $305 \mathrm{p}$.

Branson, F. A., and T. Lommasson.

1958. Quantitative effects of twenty-three years of controlled use on mountain

range. J. Range Manage. 11(2):67-70.

Bray, J. R. and J. T. Curtis.

1957. An ordination of upland forest communities of southern Wisconsin. Ecol.

Monogr. 27:325-349.

Buwai, M., and M. J. Trlica.

1977. Multiple defoliation effects on herbage yield, vigor, and total nonstructural

carbohydrates of five range species. J. Range Manage. 30(3):164-171.

Campbel1, J. B., R. W. Lodge, A. Johnston, and S. Smoliack.

1962. Range management of grasslands and adjacent parklands in the prairie provinces.

Can. Dep. Agric. Pub1. 1133, $32 \mathrm{p}$.

Caprio, J. M.

1965. Average length of freeze-free season map. Mont. Coop. Ext. Serv. Folder No. 83.

Caprio, J. M.

1973. Preliminary estimate of average annual potential evapotranspiration in inches.

Mont. Agric. Exp. Stn., Mont. State Univ., Bozeman.

Christensen, E. M.

1963. The foothill bunchgrass vegetation of central Utah. Ecology 44(1):156-157.

Conrad, C. E., and P. E. Poulton.

1956. Effects of wildfire on Idaho fescue and bluebunch wheatgrass. J. Range Manage. $19(3): 138-141$. 
Coupland, R. T.

1961. A reconsideration of grassland classification in the northern Great Plains of North America. J. Ecol. 49(1):135-167.

Daubenmire, R.

1940. Plant succession due to overgrazing in the Agropyron bunchgrass prairie of northeastern Washington. Ecology 21:55-64.

Daubenmire, R.

1952. Forest vegetation of northern Idaho and adjacent Washington, and its bearing on concepts of vegetation classification. Ecol. Monogr. 22:301-330.

Daubenmire, R.

1970. Steppe vegetation in Washington. Wash. Agric. Exp. Stn. Tech. Bu11. 62, 131 p.

Daubenmire, R., and J. B. Daubenmire.

1968. Forest vegetation of eastern Washington and northern Idaho. Wash. Agric. Exp.

Stn. Tech. Bull. 60, $104 \mathrm{p}$.

Despain, D. G.

1973. Vegetation of the Big Horn Mountains, Wyoming, in relation to substrate and climate. Ecol. Monogr. 43(3):329-355.

Dolan, J. J., and J. E. Taylor.

1972. Residual effects of range renovation on dense clubmoss and associated vegetation.

J. Range Manage. 25(1):32-37.

Ellison L.

1960. Influence of grazing on plant succession of rangelands. Bot. Rev. 26(1):1-78.

Evanko, A. B., and R. A. Peterson.

1955. Comparison of protected and grazed mountain rangelands in southwestern Montana. Ecology $36(1): 71-82$.

Everson, A. C.

1966. Effects of frequent clipping at different stubble heights on western wheatgrass (Agropyron smithii, Rydb.). Agron. J. 58(1):33-35.

Franklin, J. F., and C. T. Dyrness.

1969. Vegetation of Oregon and Washington. USDA For. Serv. Res. Pap. PNW-80, 216 p.

Pac. Northwest For. and Range Exp. Stn., Portland, Oreg.

Garrison, G. A.

1953. Effects of clipping on some range shrubs. J. Range Manage. 6(5):309-317.

Gauch, H. G., Jr., and R. H. Whittaker.

1972. Comparison of ordination techniques. Ecology 53(5):868-875.

Goetz, H.

1970. Growth and development of northern Great Plains species in relation to

nitrogen fertilization. J. Range Manage. 23(2):112-117.

Hall, F. C.

1973. Plant communities of the Blue Mountains in eastern Oregon and southeastern Washington. USDA For. Serv., Pac. Northwest Reg., R-6 Area Guide 3-1, 62 p. Portland, Oreg.

Harner, R. F., and K. T. Harper.

1973. Mineral composition of grassland species of the eastern Great Basin in relation to stand productivity. Can. J. Bot. 51(11):2037-2046.

Harniss, R. 0., and R. B. Murray.

1973. Thirty years of vegetal change following burning of sagebrush-grass range.

J. Range Manage. 26(5):322-325.

Heady, H. F.

1950. Studies on bluebunch wheatgrass in Montana and height-weight relationships of certain range grasses. Ecol. Monogr. 20:55-81.

Hironaka, M.

1977. Second year's report: Habitat-type classification for grasslands and shrublands of southern Idaho. Coll. For., Wildl, and Range Sci., Univ. Idaho, Moscow. $38 \mathrm{p}$. (Processed)

Hitchcock, C. L., A. Cronquist, M. Ownbey, and J. Thompson.

1955-69. Vascular plants of the Pacific Northwest (5 vols.). Univ. Wash. Press, Seattle. 
Holscher, C. E., and E. J. Woolfolk.

1953. Forage utilization by cattle on northern Great Plains ranges. U.S. Dep. Agric.

Circ. 918, 27 p.

Hopkins, A. D.

1938. Bioclimatics--a science of life and climatic relations. U.S. Dep. Agric., Misc. Publ. 280, $188 \mathrm{p}$.

Hormay, A. L., and M. W. Talbot.

1961. Rest-rotation grazing--a new management system for perennial bunchgrass ranges.

USDA For. Serv. Prod. Res. Rep. 51, 43 p.

Houston, W. R.

1960. Effects of water spreading on range vegetation in eastern Montana. J. Range Manage. $13(6): 289-293$.

Hubbard, W. A.

1951. Rotational grazing studies in western Canada. J. Range Manage. 4(1):25-29.

Hurd, R. M.

1959. Factors influencing herbage weight of Idaho fescue. J. Range Manage. $12(2): 61-63$.

Hurd, Richard M.

1961. Grassland vegetation in the Big Horn Mountains, Wyoming. Ecology 42(3):459-467.

Hyder, D. N., and F. A. Sneva.

1962. Selective control of big sagebrush associated with bitterbrush. J. Range Manage. $15(4): 211-215$.

Hyder, D. N., and F. A. Sneva.

1956. Herbage response to sagebrush spraying. J. Range Manage. 9(1):34-38.

Johnston, A.

1961. Comparison of lightly grazed and ungrazed range in the fescue grassland of southwestern Alberta. Can. J. Plant Sci. 41(3):615-622.

Johnson, A., and M. D. MacDonald.

1967. Floral initiation and seed production in Festuca scabrella Torr. Can. J. Plant Sci. 47(5):577-583.

Julander, 0 .

1968. Effect of clipping on herbage and flower stalk production of three summer range forbs. J. Range Manage. 21(2):74-79.

Klages, M. G., and D. E. Ryerson.

1965. Effects of nitrogen and irrigation on yield and botanical composition of western Montana range. Agron. J. 57(1):78-81.

Krall, J. L., J. R. Stroh, C. S. Cooper, and S. R. Chapman.

1971. Effect of time and extent of harvesting basin wildrye. J. Range Manage. $24(6): 414-418$.

Larson, F., and W. Whitman.

1942. A comparison of used and unused grassland mesas in the badlands of South Dakota. Ecology 23(4):438-445.

Laycock, W. A.

1967. How heavy grazing and protection affect sagebrush-grass ranges. J. Range Manage. 20(4):206-213.

Lewis, M. E.

1975. Plant communities of the Jarbridge Mountain complex, Humboldt National Forest.

USDA For. Serv., Intermt. Reg., R-4., 22 p.

Looman, J .

1969. The fescue grasslands of western Canada. Vegetation 19:128-145.

Lorenz, R. J., and G. A. Rogler.

1972. Forage production and botanical composition of mixed prairie as influenced by nitrogen and phosphorus fertilization. Agron. J. 64(2):244-249.

McCarty, E. C., and R. Price.

1942. Growth and carbohydrate content of important forage plants in central Utah as affected by clipping and grazing. U.S. Dep. Agric., Tech. Bull. 818, 51 p.

McConne11, B. R., and G. A. Garrison.

1966. Seasonal variation of available carbohydrates in bitterbrush. J. Wild1. Manage. $30(1): 168-172$. 
McConne11, B. R., and J. G. Smith.

1977. Influence of grazing on age-yield interactions in bitterbrush. J. Range Manage. $30(2): 91-93$.

McIlvanie, S. K.

1942. Carbohydrate and nitrogen trends in bluebunch wheatgrass (Agropyron spicatum) with special reference to grazing influence. Plant Physiol. 17:540-557.

McLean, A.

1970. Plant communities of the Smilkameen Valley, British Columbia, and their relationship to soils. Ecol. Monogr. 40(4):403-424.

McLean, A., and L. Marchand.

1968. Grassland ranges in the southern interior of British Columbia. Can. Dep. Agric. Pub1. $1319,28 \mathrm{p}$.

McLean, A., and W. E. Tisdale.

1972. Recovery rate of depleted range sites under protection from grazing. J. Range Manage. $25(3): 178-184$.

Morris, M. S., R. C. Kelsey, and D. Griggs.

1976. The geographic and ecological distribution of big sagebrush and other woody Artemisias in Montana. Proc. Mont. Acad. Sci. 36:56-79.

Mueggler, W. F.

1950. Effects of spring and fall grazing by sheep on vegetation of the Upper Snake River Plains. J. Range Manage. 3(4):308-315.

Mueggler, W. F.

1967. Response of mountain grassland vegetation to clipping in southwestern Montana.

Ecology $48(6): 942-949$.

Mueggler, W. F.,

1970. Influence of competition on the response of Idaho fescue to clipping. USDA

For. Serv. Res. Pap. INT-73, 10 p. Intermt. For. and Range Exp. Stn., Ogden, Utah. Mueggler, W. F.

1971. Weather variations on a mountain grassland in southwestern Montana. USDA

For. Serv. Res. Pap. INT-99, 25 p.

Mueggler, W. F.

1972a. Influence of competition on the response of bluebunch wheatgrass to clipping. J. Range Manage. 25(2):88-92.

Mueggler, W. F.

1972b. Variation in plant development and herbage yield on a mountain grassland in southwestern Montana. USDA For. Serv. Res. Pap. INT-124, 20 p. Intermt. For. and Range Exp. Stn., Ogden, Utah.

Mueggler, W. F.

1975. Rate and pattern of vigor recovery in Idaho fescue and bluebunch wheatgrass.

J. Range Manage. 28(3):198-204.

Mueggler, W. F.

1976. Number of plots required for measuring productivity on mountain grasslands in Montana. USDA For. Serv. Res. Note INT-207 (Rev.), 6 p. Intermt. For. and Range Exp. Stn., Ogden, Utah.

Mueggler, W. F., and J. P. Blaisdell.

1958. Effects on associated species of burning, rotobeating, spraying, and railing sagebrush. J. Range Manage. 11(2):61-66.

Mueller-Dombois, D., and H. E1lenberg.

1974. Aims and methods of vegetation ecology. 547 p. John Wiley and Sons, New York. Munn, L. C.

1977. I. Relationships of soils to mountain and foothill range habitat types and production in western Montana. II. Predicting soil temperature regimes of mountain and foothill sites in western Montana. Ph.D. Diss., Dept. of Crop and Soils Sci., Mont. State Univ., Bozeman, 126 p.

Munn, L. C., G. A. Nielsen, and W. F. Mueggler.

1978. Relationships of soils to mountain and foothill range habitat types and production in western Montana. Soil Sci. Soc. Am. J. 42:135-139. 
Passey, H. B., and V. K. Hugie.

1963. Fluctuating herbage production on an ungrazed sierozem soil in Idaho. J. Soil Conserv. 18:8-13.

Patten, D. T.

1963. Vegetational pattern in relation to environments in the Madison Range, Montana.

Ecol. Monogr. 33:375-406.

Patterson, J. K., and V. E. Youngman.

1960. Can fertilizers effectively increase our range land production? J. Range

Manage. $13(5): 255-257$.

Pechanec, J. F., A. P. Plummer, J. H. Robertson, and A. C. Hull.

1965. Sagebrush control on rangelands. U.S. Dep. Agric. Handb. 277, 40 p.

Pechanec, J. F., and G. Stewart.

1949. Grazing spring-fall sheep ranges of southern Idaho. U.S. Dep. Agric. Circ.

$808,34 \mathrm{p}$.

Perry, E. S.

1962. Montana in the geologic past. Mont. Bur. Mines and Geol. Bul1. 26, 78 p.

Pfister, R. D., B. L. Kovalchik, S. F. Arno, and R. C. Presley.

1977. Forest habitat types of Montana. USDA For. Serv. Gen. Tech. Rep. INT-34, 174 p.

Intermt. For. and Range Exp. Stn., Ogden, Utah.

Pickford, G. D., and E. H. Reid.

1942. Guides to determine range condition and proper use of mountain meadows

in eastern Oregon. USDA For. Serv., Pac. Northwest For. and Range Exp. Stn.,

Range Res. Rep. No. 3, 19 p. Portland, Oreg.

Pond, F. W.

1960. Vigor of Idaho fescue in relation to different grazing intensities. J. Range Manage. $13(1): 28-30$.

Pond, F. W.

1961. Effects of three intensities of clipping on the density and production of

meadow vegetation. J. Range Manage. 14(1):34-38.

Pond, F. W., and D. R. Smith.

1971. Ecology and management of subalpine ranges on the Big Horn Mountains, Wyoming.

Wyo. Agric. Exp. Stn. Res. J. 53, 25 p.

Quinnild, C. L., and H. E. Cosby.

1958. Relicts of climax vegetation on two mesas in western North Dakota.

Ecology $39(1): 29-32$.

Ratliff, R. D., and J. N. Reppert.

1974. Vigor of Idaho fescue grazed under rest-rotation and continuous grazing.

J. Range Manage. $27(6): 447-449$.

Reed, M. J., and R. A. Peterson.

1961. Vegetation, soil, and cattle responses to grazing on northern Great Plains

Range. U.S. Dep. Agric., Tech. Bul1. 1252, 79 p.

Reid, E. H., and G. D. Pickford.

1946. Judging mountain meadow range condition in eastern Oregon and eastern

Washington. U.S. Dep. Agric. Circ. 748, $31 \mathrm{p}$.

Rogler, G. A.

1951. A twenty-five year comparison of continuous and rotation grazing in the northern plains. J. Range Manage. 4(1):35-41.

Ross, R. L. and H. E. Hunter.

1976. Climax vegetation of Montana based on soils and climate. USDA Soil Conserv.

Serv., Bozeman, Mont. 64 p. (Processed).

Ross, R. L., E. P. Murray, and J. G. Heigh.

1973. Soil and vegetation inventory of near-pristine sites in Montana. USDA Soil

Conserv. Serv., 61 p. (Mimeogr. Rep.).

Schlatterer, E. F.

1972. A preliminary description of plant communities found on the Sawtooth, White

Cloud, Boulder and Pioneer Mountains. USDA For. Serv., Intermt. Reg., Ogden, Utah.

$111 \mathrm{p}$. 
Scheldt, R. S., and E. W. Tisdale.

1970. Ecology and utilization of curl-leaf mountain mahogany in Idaho. Univ. Idaho, Forest, Wildlife, and Range Exp. Stn. Note No. 15, 2 p.

Skovlin, J. M.

1967. Fluctuations in forage quality on summer range in the Blue Mountains. USDA

For. Serv. Res. Pap. PNW-44, 20 p. Pac. Northwest For. and Range Exp. Stn.,

Portland, Oreg.

Smika, D. E., J. H. Haas, and G. A. Rogler.

1963. Native grass and crested wheatgrass production as influenced by fertilizer placement and weed control. J. Range Manage. 16(1):5-8.

Smith, D. R., H. G. Fisser, N. Jefferies, and P. Stratton.

1967. Rotation grazing on Wyoming's Big Horn Mountains. Univ. Wyo. Agric.

Exp. Stn. Res. J. 13, 26 p.

Smith, D. R., and R. L. Lang.

1958. The effects of nitrogeneous fertilizers on cattle distribution on mountain

range. J. Range Manage. 11(5):248-249.

Smoliak, S.

1956. Influence of climatic condition on forage production of shortgrass rangelands. J. Range Manage. 9(2):89-91.

Smoliak, S.

1960. Effects of deferred-rotation and continuous grazing on yearling steer gains and shortgrass prairie vegetation of southeastern Alberta. J. Range Manage. $13(5): 239-243$.

Smoliak, S.

1965a. A comparison of ungrazed and 1ightly grazed Stipa bouteloua prairie in southeastern Alberta. Can J. Plant Sci. 45(2):270-275.

Smoliak, S.

1965b. Effect of mature, straw and inorganic fertilizers on northern Great Basin ranges. J. Range Manage. 18(1):11-15.

Smoliak, S.

1974. Range vegetation and sheep production at three stocking rates on Stipa bouteloua prairie. J. Range Manage. $27(1): 23-26$.

Sokal, R. R., and P. H. A. Sneath.

1963. Principles of numerical taxonomy. 359 p. W. H. Freeman and Co., San Francisco.

Southard, A. R.

1973. Soils of Montana. Mont. Agric. Exp. Stn. Bul1. 621, 42 p.

Stevens, D.

1966. Range relationships of elk and livestock, Crow Creek drainage, Montana. J. Wildlife Manage. 30(2):349-363.

Stickney, P. F.

1960. Range of rough fescue (Festuca scabrezza Torr.) in Montana. Proc. Mont. Acad.

Sci. 20:12-17.

Stoddart, L. A., and A. D. Smith.

1955. Range management. 433 p. McGraw-Hil1 Book Company, New York.

Stringer, P. W.

1973. An ecological study of grasslands in Banff, Jasper, and Waterton Lakes National Parks. Can. J. Bot. 51(2):383-411.

Thilenius, J. F., and G. R. Brown.

1974. Long-term effects of chemical control of big sagebrush. J. Range Manage. $27(3): 223-224$.

Thompson, R. M.

1970. Experimental top pruning of curl-leaf mahogany trees on the South Horn Mountain, Manti-LaSal National Forest. USDA For. Serv., Intermt. Reg., Range Improvement Notes 15(3):1-12.

Tisdale, E. W.

1947. The grasslands of the southern interior of British Columbia. Ecology $28(4): 346-382$. 
Tisdale, E. W., M. Hironaka, and M. A. Forsberg.

1965. An area of pristine vegetation in Craters of the Moon National Monument, Idaho. Ecology 46(3);349-352.

Tisdale, E. W., A. McLean, and S. E. Clark.

1954. Range resources and their management in British Columbia. J. Range Manage. $7(1): 3-9$.

USDA Soil Conservation Service.

1968. State of Montana average annual precipitation in inches: 1953-1967 map.

USDA Soil Conserv. Serv., Bozeman, Mont.

U.S. Department of Commerce.

1971. Climate of Montana. Climatography of the United States, No. 60-24, $21 \mathrm{p}$.

Voge1, W. G., and G. M. Van Dyne.

1966. Vegetation responses to grazing management on a foothill sheep range. J. Range Manage. 19(2):80-85.

Volland, L. A.

1976. Plant communities of the Central Oregon Pumice Zone. USDA For. Serv., Pac. Northwest Reg., R-6 Area Guide 4-2, 110 p.

Wight, J.R.

1976. Range fertilization in the Northern Great Plains. J. Range Manage. $29(3): 180-185$.

Wight, J. R., and L. M. White.

1974. Interseeding and pitting on a sandy range site in eastern Montana. J. Range Manage. $27(3): 206-210$.

Wilbert, 0 . E.

1963. Some effects of chemical sagebrush control on elk distribution. J. Range Manage. $16(2): 74-78$.

Wilson, A. M., G. A. Harris, and D. H. Gates.

1966a. Cumulative effects of clipping on yield of bluebunch wheatgrass. J. Range Manage. 19(2):90-91.

Wilson, A. M., G. A. Harris, and D. H. Gates.

1966b. Fertilization of mixed cheatgrass-bluebunch wheatgrass stands. J. Range Manage. 19(3):134-137.

Winward, A. H.

1970. Taxonomic and ecological relationships of the big sagebrush complex in Idaho.

Ph.D. Diss., Univ. Idaho, Moscow. 80 p.

Woolfolk, E. J.

1949. Stocking northern Great Plains sheep ranges for sustained high production.

U.S. Dep. Agric. Circ. 804,39 p.

Wright, H. A.

1971. Shrub response to fire. In: Wildland shrubs--their biology and utilization, p. 204-217. USDA For. Serv. Gen. Tech. Rep. INT-1. Intermt. For. and Range Exp.

Stn., Ogden, UT.

Zamora, B., and P. T. Tueller.

1973. Artemisia arbuscula, A. Zongizoba, and $A$. nova habitat types in northern Nevada. Great Basin Nat. 33(4):225-242. 
APPENDIXA 



\section{APPENDIX A -}

\section{METHODS}

Our approach to the development of a habitat type classification for grasslands and shrublands was conditioned by several somewhat controversial concepts: (1) no two plant communities are identical; (2) natural vegetation does not occur in discrete units, but rather as a continuum along complex environmental gradients; (3) land and dependent resources are readily managed as discrete areal units, but not as points on a continuum; and (4) similar plant communities should respond to management in similar ways. The problem, then, becomes one of alining plant communities along a continuum of vegetation similarities and expected response to perturbations, and then partitioning this continuum into relatively homogeneous units that have similar biotic potentials and anticipated responses to management. The objective, of course, is to arrive at a logical and ecologically sound classification that partitions the spectrum of natural environmental conditions and reflects existing vegetation patterns.

Ideally, communities of climax vegetation should be used for developing a classification based on biotic potentials. However, the presence of livestock in western Montana for more than 100 years has left few areas unchanged by grazing. The scarcity of ungrazed areas necessitated sampling both near-pristine areas as well as areas subject to some grazing disturbance that, according to our judgment, had not altered the vegetation appreciably. On these areas, a change in the relative amount of a species was acceptable, but not a pronounced alteration in species present. Severely altered communities usually were easily identified, but determining the degree of change at lesser levels of disturbance was very subjective unless undisturbed areas on similar sites nearby were available for comparison.

Field crews were instructed to sample the following: all relic areas and exclosures, areas typical of large expanses of grasslands and shrublands not severely altered by grazing, areas typical of small recurring grasslands and shrublands, and distinct fence-line contrasts caused by differential grazing. The latter were sampled to provide data on composition changes attributable to grazing. Areas to be avoided, in addition to those severely overgrazed, included all areas that had obviously been treated for brush control, those artificially seeded or irrigated, those crossing sharp ecotones, and those not typical of either large expanses or smaller recurring sites.

A relatively uniform $20 \times 20 \mathrm{~m}$ macroplot was selected and permanently marked in each community (stand) that was intensively sampled. The macroplot was selected to represent the stand under consideration. Forty $2 \times 5 \mathrm{dm}$ microplots were established on each macroplot; these microplots were evenly distributed along two randomly selected transects crossing the macroplot. A list of species occurring on the macroplot was prepared, and canopy cover was estimated by species and vegetation classes on each microplot. Many ephemeral species were missed, however, because many areas were sampled after these species had dried and disintegrated. The amounts of litter, bare soil, and rock on the microplots were also estimated. The general topographic and edaphic characteristics of each stand were recorded. A total of 355 stands throughout western Montana were sampled in this manner; 289 of these were in grasslands, and 66 were in shrublands.

General reconnaissance data were obtained from an additional 225 stands to supplement the geographical coverage provided by the intensively sampled stands. These data consisted of general estimates of canopy cover by species on selected sites. We made a special effort to obtain information useful for evaluating successional trends and to supply at least limited data on suspected habitat types not sampled otherwise. 
Plant species of uncertain identity were collected and returned to the laboratory for verification. A total of 494 different species representing more than 200 genera were recorded. Nomenclature follows Hitchcock and others (1955-69), Booth and Wright (1966), and Booth (1972), with Hitchcock and others given preference. A collection of voucher specimens is maintained at the Intermountain Station's Forestry Sciences Laboratory in Bozeman.

Vegetation data were processed to obtain the following species parameters: absolute and relative frequency, absolute and relative canopy cover, and a species importance value consisting of relative frequency plus relative cover. The degree of similarity between individual stands was determined numerically by Sorensen's coefficient, K=100 (2c/a+b) (Gauch and Whittaker 1972; Beals 1973).

Ordination (Bray and Curtis 1957) of approximately 200 stands using, successively, species presence, importance values, relative canopy cover, and canopy cover scaled to different values assisted formulation of ideas on logical alinment of stands. Subsequent cluster analyses (Sokal and Sneath 1963) were of limited value for alining stands into logical groups. We believe that the relatively few species exerting a potentially dominant role as expressed by a combination of morphology and amount of canopy cover should be stressed in the development of a meaningful classification. The importance of the potentially dominant role of these species appeared to be overshadowed in our ordination and cluster analyses by the great variation in presence and cover of minor species. The large variability of the many forb species especially appeared to overshadow basic similarities and dissimilarities inherent in the graminoid and shrub components which could be detected otherwise. Since we were dealing primarily with somewhat less than pristine conditions, species presence and composition within each stand had to be viewed flexibly and weight had to be given to those species considered significant indicators of environmental differences. The forbs generally appeared more accidental on these areas than the graminoids and shrubs; in any event, most forbs appeared to be unreliable indicators of suspected environmental differences. Rather than intensively pursue the refinement of groupings obtained by using these numerical techniques, we decided to rely heavily upon the use of synthesis or association tables (Mueller-Dombois and E1lenburg 1974).

The stands were first grouped into "series" determined by the primary climax dominant species. This determination was based upon judgment conditioned by the results of computer analysis and experience. Shrubs were generally considered first order dominants, and graminoids second order dominants. No single forb species appeared to assume an overall dominant position in any of the communities sampled. If the dominant species of the stand had a minimum canopy cover of approximately 5 percent combined with a frequency of 25 to 50 percent depending upon the species growth habit, the stand would qualify for that species series. These minimum cover and frequency values were merely guides which were adjusted somewhat depending upon estimated grazing alteration.

Stands assigned to a series were placed in a "dynamic" association table which permitted horizontal alinment of stands and vertical alinment of species. The position of stands and species were adjusted until they were arranged into what appeared to be a sensible order along a continuum of vegetation similarity. Factors considered in selecting species upon which to base stand alinments included species dominance in the stands, suspected affinity to specific environmental conditions, and constancy of species within proposed groups. Partitioning of the continuum into "habitat types" followed. Usually one end of the series continuum differed obviously from the other, and usually this difference appeared to reflect a moisture gradient. Different species tended to occur at opposite ends of the continuum, but other species were so widely scattered that they appeared accidental; very likely this difference in species behavior reflects differences in overall ecological amplitude of the various species within the series. 
Actual separation of habitat types was based upon dominant and codominant species, reasonable consistency of the secondary species, and the likelihood of similar anticipated response to management. A "phase" was designated only when consistent dissimilarities of one or more secondary species suggested a real environmental difference, but one not sufficiently great to warrant separate habitat type status.

A dichotomous vegetation key was prepared to assist recognition of habitat types and phases in the field. The key was tested for reliability both by checking against the data for each of the 580 stands sampled and by field use.

To develop management-related information on important habitat types, we conducted additional field studies and, by thoroughly reviewing relevant literature, related previous research findings to our defined habitat types. The need for specific information on successional relations, forage productivity, and the relationship of soils to the defined habitat types prompted the additional field studies.

Information on successional relations attributable to grazing was developed by intensive field sampling of 20 pairs of differentially grazed stands representing 8 different habitat types. These pairs consisted of inside-outside exclosure comparisons as well as other fence-line contrasts under obviously different grazing intensities. A " $t$ " test was used to determine whether differences between the canopy cover of a species were statistically valid or simply a result of sample variation. (Comparisons of pairedstands are shown in appendix G). Data from the intensively sampled paired-stands were supplemented by observations of more than 140 areas where we specifically sought information on compositional changes attributable to grazing. This information consisted of qualitative judgments based on adjacent areas that had been differentially grazed. In addition, numerous publications relating to grassland and shrubland vegetation in the Northern Rocky Mountains were scanned for information on compositional changes caused by grazing. Where possible, we related these published findings to our classification categories. The consistency of reaction of species to grazing was then summarized by habitat types.

The potential of different sites for producing vegetation differs greatly in the highly varied environment of the Northern Rocky Mountains. Since habitat types reflect overall site potential, we can expect total vegetation biomass and consequent forage production to differ greatly between habitat types. In a separate study we measured above-ground biomass production on 12 of the more important habitat types as judged from amount of area occupied and potential value for producing forage. Each of the 12 habitat types was represented by 2 to 4 stands selected to represent the range in production that might be expected within a given habitat type. Production on each stand was sampled over 3 consecutive years, 1974 through 1976, to evaluate the variability in production that occurs between years and is attributable to weather. During this 3-year period annual precipitation in western Montana ranged from approximately three-fourths to 1-1/2 times the long-term average; April through July precipitation ranged from approximately one-half to $1-1 / 2$ times the long-term average. Production was determined by a double sampling technique (clipping and estimation) on 50 permanent $4.8 \mathrm{ft}^{2}\left(0.46 \mathrm{~m}^{2}\right)$ plots distributed in random 5-plot clusters on each stand. The sampling intensity was designed to produce data that, for between-stand comparisons, have a 95 percent probability of estimating vegetation classes and major species within at least 20 percent of the population mean (Mueggler 1976). The summarized data are included in the discussion of the appropriate habitat type descriptions in this report. A comprehensive evaluation of forage production variability within and between habitat types, and between years, will be published later. 
The physical and chemical properties of soils on important habitat types were determined through a cooperative study with the Soils Department of Montana State University. Soil profiles were described and soil properties analyzed on 22 stands selected to represent 8 different habitat types. All 22 of these stands were part of the aforementioned study to determine biomass productivity. Correlations between soil characteristics and herbage production were determined (Munn 1977). The soils information for the stands where data were collected is shown in appendix $C$.

Other information on management implications, e.g., species palatability, proper use, season of use, range improvements, etc., was obtained primarily from published literature and existing guides for range managers. Relevant information of this sort is summarized in the discussion for each habitat type. The source of the information is cited where appropriate. 


\section{APPENDIX B}





\section{APPENDIX B}

\section{WESTERN MONTANA ENVIRONMENT}

\section{Topography and Geology}

Montana is divided from west to east into three approximately equal sections of vastly different topography. The western third is part of the northern extension of the Rocky Mountains, the eastern third is the western edge of the Great Plains, and the central section is a mixture of plains and isolated mountain masses. The mountainous western portion covered by our vegetation classification consists of some 40 individual mountain ranges up to 20 miles $(32 \mathrm{~km}$ ) wide and from 50 to 100 miles (80 to $160 \mathrm{~km}$ ) long (Perry 1962). Most of the mountain ranges lie parallel and are oriented in a northwesterly-southeasterly direction. Mountain elevations average on $1 \mathrm{y}$ 6,000 ft $(1,800 \mathrm{~m})$ in northwestern Montana; these elevations gradually increase to $10,000 \mathrm{ft}$ $(3,000 \mathrm{~m})$ as one proceeds southward to the Beartooth Plateau near Yellowstone National Park.

The mountain ranges alternate with broad, nearly level valleys 5 to 20 miles ( 8 to $32 \mathrm{~km}$ ) wide and 25 to 75 miles $(40$ to $120 \mathrm{~km}$ ) long. The average elevation of the major valleys also increases from 2,900 ft $(880 \mathrm{~m})$ around Kalispel1 in northwestern Montana to $5,400 \mathrm{ft}(1,650 \mathrm{~m})$ in the southwestern part of the State near Dillon. The floors of most of the major valleys consist of sediments deposited in lakes formed in the valleys during the late Tertiary and early Quaternary Periods.

The geologic history of Montana covers well over 500 million years and has been thoroughly described by Perry (1962). The varied forces at work since the Precambrian Era are responsible for the highly varied topography and rock strata that strongly influence current vegetation patterns. Therefore, a brief review of the geologic history of western Montana is appropriate.

The basal rock strata of western Montana consists of a complex of Precambrian metamorphics with igneous intrusions and lava extrusions. During the Precambrian Era, inland seas repeatedly formed, sediments were deposited, and Precambrian mountains arose and were subsequently eroded to a plain. The Belt series sediments, which were later consolidated into argillites and quartzites, originated in the Precambrian Era. Inland seas covered western Montana during the Paleozoic Era also depositing primarily limestone sediments. Some of these limestone strata in southwestern Montana are several thousand feet thick.

Invasion and recession of inland seas continued through the Mesozoic Era, with additional depositions consisting primarily of shales and sandstones. The last of the great marine invasions of western Montana occurred during the late Cretaceous Period. At this time also, lava beds up to $5,000 \mathrm{ft}(1,500 \mathrm{~m})$ were formed by volcanic activity in portions of western Montana.

The Rocky Mountains first began rising by folding and faulting of the thick layers of sedimentary deposits in the late Cretaceous and early Tertiary Periods. At this time, the Boulder batholith, extending from Helena to beyond Butte, was formed. Most such batholithic intrusions as well as volcanic extrusions occurred in the southwestern part of the State. The folded and faulted mountain masses were nearly leveled by erosion during the latter part of the early Tertiary Period. The second or present stage in mountain development, which is superimposed on the earlier eroded mountain structure, 
occurred primarily by block faulting in the middle and late Tertiary Period. Most of these mountains were formed as parallel ranges trending northwest and southeast. Other mountain masses, particularly at the eastern edge of the Northern Rocky Mountains, were created by such forces as vertical uplift (e.g., Beartooth Plateau) and intrusions of igneous material (e.g. Crazy Mountains).

During the late Tertiary Period, large lakes were formed in the numerous valleys between the recently formed mountains. These lakes accumulated sediments up to 2,000 ft $(600 \mathrm{~m})$ thick, which are responsible for the present broad, relatively flat valley bottoms consisting of deep, relatively recent sedimentary deposits.

Continental and mountain glaciation altered western Montana during the Pleistocene Epoch. The Cordilleran ice sheet extended some 60 to $70 \mathrm{miles}$ (100 to $115 \mathrm{~km}$ ) into northwestern Montana, blocked the Clark Fork River, and created Glacial Lake Missoula. This massive lake covered $2,900 \mathrm{mi}^{2}\left(7,500 \mathrm{~km}^{2}\right)$, was up to $2,000 \mathrm{ft}(600 \mathrm{~m})$ deep, and left Pleistocene sedimentary deposits on many of the extensive valley floors in the northwestern part of the State. All of the higher mountains were altered by mountain glaciers during this period. Both the Cordilleran and mountain glaciers left deposits of morainal rubble and glacial till.

\section{Soils}

Soils in the mountainous regions of western Montana are described by Southard (1973). Forested soils in the drier 12- to 25-in (30- to 64-cm) precipitation zone generally belong to the Gray Wooded great soil group (Cryochrepts, Cryorthods, and Cryoboralfs under the 1968 National Soils Classification System). Brown Podzolic soils (Paleboralfs and Cryorthods) usually are found in the forested areas within the 25- to $50-$ in $(64-$ to $127-\mathrm{cm})$ precipitation zone.

On the nonforested sloping and undulating uplands in western Montana, Chestnut, Chernozem, and Calcisol soils (Haploborolls, Argiborolls, and Cryoborolls) predominate. Chestnut, Chernozem, Brown, Calcisol, and Lithosol soils (Haploborolls, Argiborolls, Cryoborolls, and Calciborolls) are found on the nonforested foothills, fans, and terraces. Alluvial soils (Hapludolls and Cryoborolls) are prominent on the bottom lands.

\section{Climate}

The climate of western Montana differs greatly over short distances because of the extreme topographic variation. The Continental Divide, which runs in a generally north-south direction, exerts a pronounced influence on the climate. The climate west of the Divide is modified by air mass penetration from the north Pacific Ocean; whereas east of the Divide continental influences predominate. Consequently, areas west of the Divide generally experience cooler summers, milder winters, greater cloudiness, precipitation more evenly distributed throughout the year, and lighter winds than areas east of the Divide (U.S. Dep. Commer. 1971). 
Weather records from Kalispel1, Missoula, Hamilton, and Butte indicate that approximately 55 percent of the annual precipitation west of the Divide occurs from April through September. For stations adjacent to the mountains east of the Divide, Browning, Choteau, Helena, Bozeman, and White Sulphur Springs, approximately 70 percent of the annual precipitation falls during these months. Late spring (May and June) is the period of greatest precipitation. Areas west of the Divide receive approximately a fourth and areas east of the Divide approximately a third of their total annual precipitation during this period. Heavy snow storms can occur in the mountainous areas as early as mid-September and as late as May. Mountain snow packs are highly variable but may exceed $8 \mathrm{ft}(2.5 \mathrm{~m})$.

Mean maximum July temperatures in western Montana range from considerably less than $72^{\circ} \mathrm{F}\left(22^{\circ} \mathrm{C}\right)$ at the higher elevations in the mountains to more than $90^{\circ} \mathrm{F}\left(32^{\circ} \mathrm{C}\right)$ in the lower valleys. Mean minimum temperatures in January range from $-2^{\circ}$ to $20^{\circ} \mathrm{F}\left(-19^{\circ}\right.$ to $\left.7^{\circ} \mathrm{C}\right)$. Maximum temperatures greater than $100^{\circ} \mathrm{F}\left(38^{\circ} \mathrm{C}\right)$ sometimes occur at the lower elevations, while minimum temperatures east of the Divide can fall to $-50^{\circ} \mathrm{F}\left(-45^{\circ} \mathrm{C}\right)$ or 1 ower (U.S. Dep. Commer. 1971).

Effective precipitation and temperature are the primary climatic factors governing vegetation distribution. Both of these factors are strongly influenced by topography. Isohyetal lines for Montana are illustrated by Ross and Hunter (1976). Although annual precipitation at the higher elevations on the windward (generally western) side of the mountains often may exceed 40 in $(100 \mathrm{~cm})$, rain-shadow areas in adjacent valleys may receive less than 10 in $(25 \mathrm{~cm})$. Summer temperatures decrease with elevational increases, which in turn reduce moisture loss from evapotranspiration and improve moisture relations for plant growth. On the Gravelly Range of mountains in southwestern Montana, this decrease in maximum summer temperatures amounted to between $4.7^{\circ}$ and $6.3^{\circ} \mathrm{F}\left(2.6^{\circ}\right.$ and $3.5^{\circ} \mathrm{C}$ ) for each $1,000 \mathrm{ft}(305 \mathrm{~m})$ elevational rise (Mueggler 1971).

As a direct consequence of the interrelationships between topography and effective precipitation, grasslands and shrublands are generally found on the valley bottoms, low foothills, and many southerly aspects at the higher elevations. Forests occur where moisture stress is less severe. Climatic, topographic, and edaphic balances are so tenuous on some mountain ranges (e.g., Gravelly Range) that the vegetation consists of a mosaic of forests and grasslands with ill-defined causal relationships. From his research into forest-grassland patterns in the Madison Range, Patten (1963) concluded that although the entire holocoenotic environment determines vegetation patterns, the most common limiting factors for tree growth are those affecting water availability. 



\section{APPENDIX C -}

\section{ENVIRONMENT PARAMETERS FOR IMPORTANT HABITAT TYPES}

General environmental parameters, soil physical properties, and soil chemical

properties are given in separate tables for eight important habitat types: STCO/BOGR, $A G S P / B O G R$, AGSP/AGSM, EESC/AGSP, EESC/EEID, EEID/AGSP, FEID/AGCA, and ARTR/FEID. 



\section{C1. - General}

General environmental parameters on stands selected to span the range in vegetative production within eight important habitat types

\begin{tabular}{|c|c|c|c|c|c|c|c|}
\hline $\begin{array}{l}\text { Stand } \\
\text { No. }\end{array}$ & $\begin{array}{l}\text { Average } \\
\text { production } 1\end{array}$ & Elevation & Aspect & Slope & $\begin{array}{l}\text { Estimated } \\
\text { precipitation }{ }^{2}\end{array}$ & $\begin{array}{l}\text { Estimated } \\
\text { potential } \\
\text { evapotrans- } \\
\text { piration }{ }^{3}\end{array}$ & $\begin{array}{l}\text { Estimated } \\
\text { frost-free } \\
\text { season }\end{array}$ \\
\hline & $\mathrm{kg} / \mathrm{ha}$ & $m$ & & $\%$ & $\mathrm{~cm}$ & $\mathrm{~cm}$ & Days \\
\hline
\end{tabular}

Stipa comata/Boutezoua gracizis h.t.

$\begin{array}{rrrrrrrr}102 & 271 & 1,395 & \text { SW } & 5 & 25 & 57 & 112 \\ 180 & 787 & 1,536 & W & 10 & 38 & 56 \\ 358 & 949 & 1,152 & \mathrm{NE} & 12 & 33 & 64 & 115\end{array}$

Agropyron spicatum/Bouteloua gracizis h.t.

\begin{tabular}{|c|c|c|c|c|c|c|c|}
\hline 9 & 483 & 1,414 & W & 25 & 33 & 60 & 115 \\
\hline 149 & 488 & 1,524 & SW & 2 & 73 & 56 & 90 \\
\hline 179 & 867 & 1,359 & E & 1 & 36 & 65 & 121 \\
\hline
\end{tabular}

Agropyron spicatum/A. smithii h.t.

$\begin{array}{rrrrrrr}83 & 762 & 1,344 & S & 11 & 28 & 98 \\ 248 & 900 & 1,377 & \text { SE } & 36 & 30 & 64\end{array}$

Festuca scabrella/Agropyron spicatum h.t.

\begin{tabular}{|c|c|c|c|c|c|c|c|}
\hline 232 & 998 & 1,014 & $N$ & 7 & 71 & 53 & 117 \\
\hline 87 & 1,346 & 1,591 & S & 4 & 28 & 41 & 88 \\
\hline
\end{tabular}

Festuca scabrella/Eestuca idahoensis h.t.

$\begin{array}{rrrrrrrr}304 & 1,261 & 1,143 & \mathrm{NE} & 18 & 48 & 53 & 115 \\ 372 & 1,597 & 2,157 & \mathrm{~S} & 19 & 79 & 42 & 81 \\ 208 & 1,828 & 2,011 & \mathrm{SE} & 16 & 53 & 39 & 60\end{array}$

Festuca idahoensis/Agropyron spicatum h.t.

$\begin{array}{rrrrrrrr}27 & 734 & 2,228 & \mathrm{~S} & 7 & 48 & 37 & 82 \\ 105 & 834 & 1,786 & \mathrm{SW} & 12 & 46 & 44 & 98 \\ 23 & 1,375 & 1,743 & \mathrm{NW} & 12 & 38 & 59 & 110 \\ 28 & 1,449 & 2,234 & \mathrm{~N} & 12 & 48 & 82\end{array}$

Festuca idahoensis/Agropyron caninum h.t.

$\begin{array}{rrrrrrrr}125 & 1,338 & 2,438 & \text { SW } & 9 & 43 & 36 & 32 \\ 41 & 1,727 & 2,170 & \mathrm{E} & 7 & 46 & 39 & 37 \\ 56 & 1,874 & 2,353 & \mathrm{SE} & 13 & 61 & 69\end{array}$

Artemisia tridentata/Festuca idahoensis h.t.

\begin{tabular}{|c|c|c|c|c|c|c|c|}
\hline 272 & 854 & 1,926 & W & 10 & 48 & 37 & 70 \\
\hline 140 & 1,208 & 2,090 & NE & 19 & 43 & 38 & 65 \\
\hline 46 & 1,618 & 2,145 & NE & 9 & 46 & 39 & 53 \\
\hline
\end{tabular}

IAir-dry vegetation production averaged over a 3-year period.

${ }^{2}$ USDA Soil Conservation Service 1968.

${ }^{3}$ Caprio 1973.

${ }^{4}$ Caprio 1965. 


\section{C2. - Soil Physical Properties}

Soil physical properties for stands selected to span range in vegetative production within eight important habitat types

\begin{tabular}{|c|c|c|c|c|c|c|c|c|c|c|}
\hline St and & Average & & & & Textu & & Coarse & Bulk & Available & Parent \\
\hline No. & production & Horizon & Thickness & Sand & Silt & $\overline{C l a y}$ & fragments & density & water & material \\
\hline
\end{tabular}

Stipa comata/Bouteloua gracilis h.t.

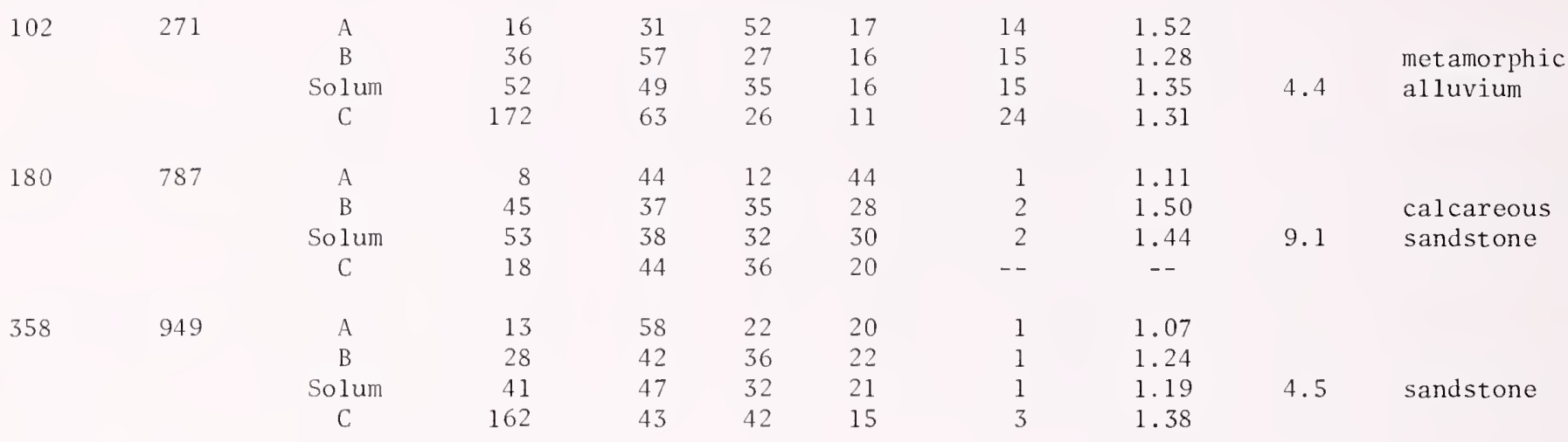

Agropyron spicatum/Bouteloua gracilis h.t.

\begin{tabular}{|c|c|c|c|c|c|c|c|c|c|c|}
\hline \multirow[t]{4}{*}{9} & 483 & A & 18 & 44 & 36 & 20 & 22 & 0.97 & \multirow{4}{*}{1.3} & \multirow{4}{*}{ metamorphic } \\
\hline & & B & 0 & -- & -- & -- & -- & -- & & \\
\hline & & Solum & 18 & 44 & 36 & 20 & 22 & 0.97 & & \\
\hline & & C & 48 & 61 & 21 & 18 & 12 & 1.53 & & \\
\hline \multirow[t]{4}{*}{149} & 488 & A & 15 & 57 & 25 & 18 & 30 & 1.02 & & \\
\hline & & B & 26 & 63 & 13 & 24 & 60 & 1.70 & & mixed \\
\hline & & Solum & 41 & 61 & 17 & 22 & 49 & 1.45 & 2.7 & alluvium \\
\hline & & C & 99 & 69 & 11 & 20 & 47 & 1.21 & & \\
\hline \multirow[t]{4}{*}{179} & 867 & A & 10 & 42 & 28 & 30 & 26 & 1.11 & & \\
\hline & & B & 38 & 50 & 20 & 30 & 7 & 1.37 & & igneous \\
\hline & & Solum & 48 & 48 & 22 & 30 & 11 & 1.32 & 7.0 & alluvium \\
\hline & & C & 86 & 64 & 21 & 15 & 38 & 2.06 & & \\
\hline
\end{tabular}

Agropyron spicatum/A. smithii h.t.

\begin{tabular}{|c|c|c|c|c|c|c|c|c|c|c|}
\hline \multirow[t]{4}{*}{83} & 762 & A & 25 & 54 & 19 & 27 & 8 & 1.00 & \multirow{4}{*}{2.7} & \multirow{4}{*}{ igneous } \\
\hline & & B & 0 & -- & -- & -- & -- & -- & & \\
\hline & & Solum & 25 & 54 & 19 & 27 & 8 & 1.00 & & \\
\hline & & C & 157 & 46 & 40 & 14 & 3 & 1.47 & & \\
\hline \multirow[t]{4}{*}{248} & 900 & A & 20 & 30 & 39 & 31 & 27 & 1.08 & \multirow{4}{*}{3.0} & \multirow{4}{*}{$\begin{array}{l}\text { sandstone } \\
\text { siltstone }\end{array}$} \\
\hline & & B & 10 & 36 & 33 & 31 & 31 & 0.99 & & \\
\hline & & Solum & 30 & 32 & 37 & 31 & 28 & 1.05 & & \\
\hline & & C & 48 & 46 & 31 & 23 & 58 & 1.53 & & \\
\hline
\end{tabular}

Eestuca scabrella/Agropyron spicatum h.t.

\begin{tabular}{|c|c|c|c|c|c|}
\hline 232 & 998 & A & 15 & 42 & 32 \\
\hline & & B & 28 & 43 & 14 \\
\hline & & Solum & 43 & 43 & 20 \\
\hline & & C & 132 & 20 & 23 \\
\hline 87 & 1,346 & A & 25 & 49 & 26 \\
\hline & & B & 0 & -- & -- \\
\hline & & Solum & 25 & 49 & 26 \\
\hline & & C & 102 & 55 & 23 \\
\hline
\end{tabular}

1.41

1.32

1.37

7.8 igneous

1.21

- 21

1.71

mixed

outwash

(con.) 
APPENDIX C2 (con.)

\begin{tabular}{|c|c|c|c|c|c|c|c|c|c|c|}
\hline \multirow{2}{*}{$\begin{array}{c}\text { Stand } \\
\text { No. }\end{array}$} & \multirow{2}{*}{$\begin{array}{l}\text { Average } \\
\text { production }\end{array}$} & \multirow[b]{2}{*}{ Horizon } & \multirow[b]{2}{*}{ Thickness } & \multicolumn{3}{|c|}{ Texture } & \multirow{2}{*}{$\begin{array}{c}\text { Coarse } \\
\text { fragments }\end{array}$} & \multirow{2}{*}{$\begin{array}{c}\text { Bulk } \\
\text { density }\end{array}$} & \multirow{2}{*}{$\begin{array}{c}\text { Available } \\
\text { water }\end{array}$} & \multirow{2}{*}{$\begin{array}{c}\text { Parent } \\
\text { material }\end{array}$} \\
\hline & & & & Sand & Silt & Clay & & & & \\
\hline
\end{tabular}

Festuca scabrelza/Festuca idahoensis h.t.

\begin{tabular}{|c|c|c|c|c|c|c|c|c|c|c|}
\hline \multirow[t]{3}{*}{304} & 1,261 & $\begin{array}{l}\text { A } \\
B\end{array}$ & $\begin{array}{l}23 \\
18\end{array}$ & $\begin{array}{l}28 \\
44\end{array}$ & $\begin{array}{l}52 \\
42\end{array}$ & $\begin{array}{l}20 \\
14\end{array}$ & $\begin{array}{r}5 \\
28\end{array}$ & $\begin{array}{l}0.85 \\
1.12\end{array}$ & \multirow{3}{*}{3.0} & \multirow{3}{*}{ metamorphic } \\
\hline & & Solum & 41 & 35 & 48 & 17 & 15 & 0.97 & & \\
\hline & & C & 69 & 31 & 48 & 21 & 21 & 1.70 & & \\
\hline \multirow[t]{4}{*}{372} & 1,597 & $\mathrm{~A}$ & 28 & 31 & 52 & 17 & 15 & 0.75 & \multirow{4}{*}{4.0} & \multirow{4}{*}{ metamorphic } \\
\hline & & B & 46 & 27 & 55 & 18 & 34 & 1.21 & & \\
\hline & & Solum & 74 & 28 & 54 & 18 & 27 & 1.04 & & \\
\hline & & C & 41 & 24 & 54 & 22 & 45 & 1.28 & & \\
\hline \multirow[t]{4}{*}{208} & 1,828 & $\mathrm{~A}$ & 30 & 57 & 27 & 16 & 19 & 1.21 & \multirow{4}{*}{9.9} & \multirow{4}{*}{ metamorphic } \\
\hline & & B & 60 & 53 & 26 & 21 & 34 & 1.87 & & \\
\hline & & Solum & 90 & 54 & 26 & 20 & 29 & 1.65 & & \\
\hline & & C & 13 & 50 & 24 & 26 & 12 & -- & & \\
\hline
\end{tabular}

Festuca idahoensis/Agropyron spicatum h.t.

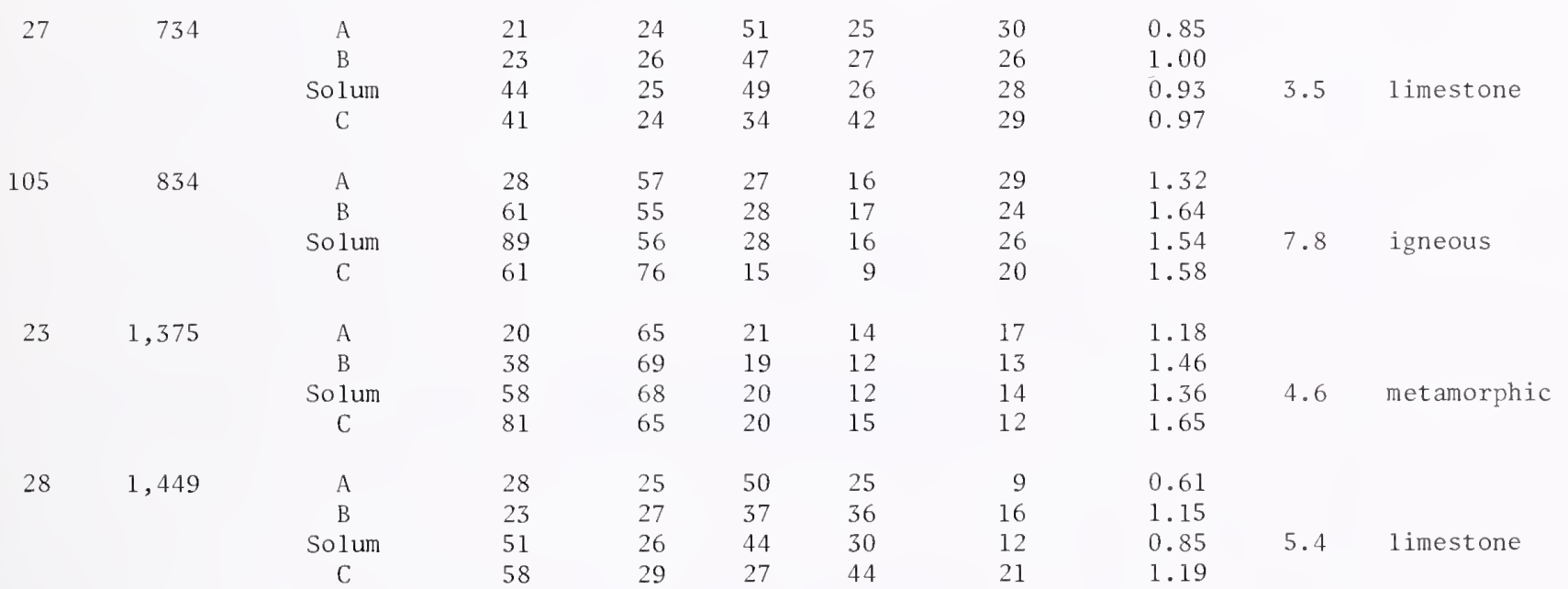

Festuca idahoensis/Agropyron caninum h.t.

\begin{tabular}{|c|c|c|c|c|c|c|c|c|c|c|}
\hline \multirow[t]{4}{*}{125} & 1,338 & A & 23 & 58 & 32 & 10 & 10 & 0.72 & & \\
\hline & & B & 15 & 54 & 32 & 14 & 33 & 1.51 & & \\
\hline & & Solum & 38 & 56 & 32 & 12 & 19 & 1.03 & 2.8 & igneous \\
\hline & & C & 56 & 63 & 24 & 13 & 56 & 2.50 & & \\
\hline \multirow[t]{4}{*}{41} & 1,727 & A & 51 & 35 & 44 & 21 & 2 & 0.85 & & \\
\hline & & B & 48 & 36 & 42 & 22 & 28 & 1.31 & & \\
\hline & & Solum & 99 & 35 & 43 & 22 & 15 & 1.07 & 7.4 & igneous \\
\hline & & C & 41 & 32 & 45 & 23 & 32 & 0.85 & & \\
\hline \multirow[t]{4}{*}{56} & 1,874 & $\mathrm{~A}$ & 56 & 47 & 11 & 42 & 1 & 0.89 & & \\
\hline & & B & 68 & 41 & 33 & 26 & 5 & 1.35 & & \\
\hline & & Solum & 124 & 44 & 23 & 33 & 3 & 1.14 & 18.0 & sandstone \\
\hline & & C & 61 & 66 & 26 & 8 & 1 & 1.40 & & \\
\hline
\end{tabular}

Artemisia tridentata/Festuca idahoensis h.t.

\begin{tabular}{|c|c|c|c|c|c|c|c|c|c|c|}
\hline \multirow[t]{4}{*}{272} & 854 & $\mathrm{~A}$ & 10 & 58 & 14 & 28 & 19 & 1.05 & \multirow{4}{*}{8.8} & \multirow{4}{*}{ igneous } \\
\hline & & B & 66 & 47 & 20 & 33 & 59 & 2.68 & & \\
\hline & & Solum & 76 & 48 & 19 & 33 & 54 & 2.47 & & \\
\hline & & C & 25 & 30 & $30^{\circ}$ & 40 & 15 & 1.56 & & \\
\hline \multirow[t]{4}{*}{140} & 1,208 & $\mathrm{~A}$ & 41 & 68 & 20 & 12 & 15 & 1.83 & \multirow{4}{*}{3.4} & \multirow{4}{*}{ gneiss } \\
\hline & & B & 0 & -- & -- & -- & -- & -- & & \\
\hline & & Solum & 41 & 68 & 20 & 12 & 15 & 1.83 & & \\
\hline & & C & 102 & 84 & 12 & 4 & 18 & 1.56 & & \\
\hline \multirow[t]{4}{*}{46} & 1,618 & A & 54 & 32 & 33 & 35 & 3 & 0.84 & \multirow{4}{*}{8.4} & \multirow{4}{*}{ igneous } \\
\hline & & B & 30 & 39 & 32 & 18 & 22 & 1.21 & & \\
\hline & & Solum & 84 & 34 & 37 & 29 & 10 & 0.97 & & \\
\hline & & C & 69 & 31 & 42 & 27 & 28 & 1.42 & & \\
\hline
\end{tabular}




\section{C3. - Soil Chemical Properties}

Chemical properties of soil solum for stands selected to span range in vegetetative production within eight important habitat types

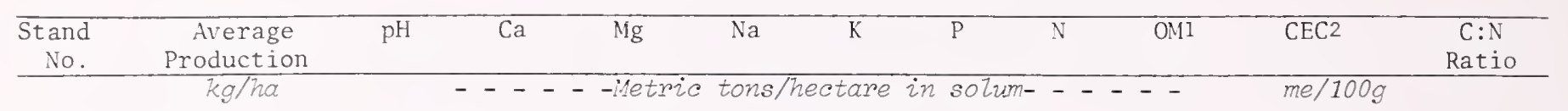

Stipa comata/Bouteloua gracilis h.t.

$\begin{array}{rrrrrrrrrrrr}102 & 271 & 7.7 & 47.9 & 2.9 & 0.10 & 2.2 & 0.06 & 1.2 & 72 & 10.0 & 21: 1 \\ 180 & 787 & 7.6 & 51.6 & 5.1 & .35 & 1.2 & .02 & .6 & 137 & 17.7 & 29: 1 \\ 358 & 949 & 7.6 & 36.0 & 2.8 & .18 & 1.0 & .02 & 1.0 & 87 & 14.4 & 23: 1\end{array}$

Agropyron spicatum/Bouteloua gracizis h.t.

$\begin{array}{rrrrrrrrrrrr}9 & 483 & 7.0 & 4.3 & .5 & .05 & .5 & .02 & .6 & 42 & 20.0 & 44: 1 \\ 149 & 488 & 7.1 & 9.3 & 1.4 & .08 & 1.1 & .07 & .6 & 62 & 17.1 & 34: 1 \\ 179 & 867 & 7.1 & 52.1 & 2.4 & .16 & 1.5 & .04 & .7 & 136 & 22.2 & 35: 1\end{array}$

Agropyron spicatum/A. smithii h.t.

$\begin{array}{rrrrrrrrrrrrr}83 & 762 & 6.9 & 12.6 & .8 & .01 & .6 & .07 & 2.0 & 61 & 20.5 & 18: 1 \\ 248 & 900 & 7.0 & 9.7 & .4 & .07 & .5 & .04 & 1.8 & 68 & 17.5 & 22: 1\end{array}$

Festuca scabrella/Agropyron spicatum h.t.

$\begin{array}{rrrrrrrrrrrrr}232 & 998 & 6.8 & 49.0 & 8.6 & 1.07 & 2.4 & .03 & 1.8 & 141 & 30.1 & 28: 1 \\ 87 & 1,346 & 6.9 & 10.0 & .6 & .01 & .4 & .04 & 2.9 & 94 & 22.7 & 19: 1\end{array}$

Festuca scabrella/Festuca idahoensis h.t.

$\begin{array}{rrrrrrrrrrrr}304 & 1,261 & 6.9 & 4.2 & .7 & .20 & 1.1 & .02 & 1.8 & 120 & 15.8 & 31: 1 \\ 372 & 1,597 & 7.1 & 18.7 & 1.0 & .09 & .9 & .02 & 5.7 & 249 & 24.2 & 18: 1 \\ 208 & 1,828 & 6.2 & 22.9 & 3.9 & .21 & 3.6 & .12 & 3.9 & 280 & 18.3 & 30: 1\end{array}$

Festuca idahoensis/Agropyron spicatum h.t.

$\begin{array}{rrrrrrrrrrrrr}27 & 734 & 7.4 & 41.9 & 1.8 & .08 & 1.0 & .01 & 2.3 & 153 & 25.1 & 25: 1 \\ 105 & 834 & 6.5 & 17.5 & 3.3 & .04 & 3.0 & .50 & 2.4 & 138 & 12.5 & 19: 1 \\ 23 & 1,375 & 6.8 & 13.4 & 2.3 & .26 & 1.9 & .04 & 1.0 & 127 & 15.2 & 51: 1 \\ 28 & 1,449 & 7.2 & 55.4 & 2.1 & .04 & 1.5 & .01 & 3.7 & 197 & 28.8 & 22: 1\end{array}$

Festuca idahoensis/Agropyron caninum h.t.

$\begin{array}{rrrrrrrrrrrr}125 & 1,338 & 6.5 & 4.5 & .5 & .03 & 1.1 & .07 & 2.8 & 206 & 18.2 & 32: 1 \\ 41 & 1,727 & 6.0 & 16.2 & 2.1 & -5 & 3.3 & .09 & 4.9 & 259 & 18.9 & 27: 1 \\ 56 & 1,874 & 6.0 & 71.3 & 11.5 & .68 & 2.9 & .20 & 4.1 & 247 & 31.7 & 24: 1\end{array}$

Artemisia tridentata/Festuca idahoensis h.t.

\begin{tabular}{rrrrrrrrrrrrr}
272 & 854 & 7.0 & 17.3 & 1.6 & .06 & 1.6 & .18 & 1.0 & 114 & 10.6 & $29: 1$ & 1 \\
140 & 1,208 & 6.8 & 7.8 & 1.1 & .02 & 1.1 & .04 & 2.4 & 125 & 14.3 & $31: 1$ & 25 \\
46 & 1,618 & 6.4 & 16.3 & 2.4 & .16 & 2.9 & .07 & 6.3 & 238 & 18.5 & $20: 1$ & \\
\hline
\end{tabular}

${ }^{1}$ Organic matter.

${ }^{2}$ Cation exchange capacity. 


\section{APPENDIX D}




\section{APPENDIX D}

\section{COVER CLASS SUMMARIES BY HABITAT TYPES}

Mean and range of ground cover, and number of species identified on 20x20 m sample areas; number of stands sampled in each habitat type are shown in parentheses following the habitat type name

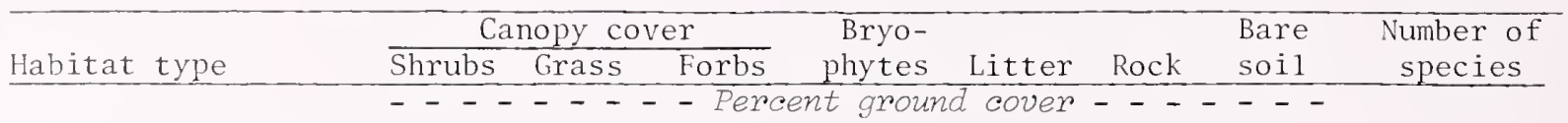

Stipa comata/Bouteloua gracilis h.t. (7)

$\begin{array}{lcccccccc}\text { Mean } & 3 & 54 & 3 & 10 & 23 & 5 & 24 & 16 \\ \text { Range } & 0-13 & 27-65 & 1-12 & 5-16 & 3-63 & 1-10 & 12-34 & 8-32\end{array}$

STCO/BOGR, Agropyron smithii phase (19)

$\begin{array}{lcccccccc}\text { Mean } & 6 & 67 & 11 & 14 & 55 & 4 & 9 & 25 \\ \text { Range } & <120 & 35-90 & 2-44 & <1-48 & 11-86 & 0-25 & 2-19 & 11-42\end{array}$

Agropyron spicatum/Bouteloua gracizis h.t. (8)

$\begin{array}{lcccccccc}\text { Mean } & 7 & 35 & 7 & 13 & 20 & 18 & 14 & 20 \\ \text { Range } & 4-17 & 24-45 & 0-11 & 4-26 & 12-26 & 2-46 & 4-42 & 11-28\end{array}$

AGSP/BOGR, Liatris punctata phase (14)

$\begin{array}{lcccccccc}\text { Mean } & 6 & 59 & 16 & 17 & 53 & 6 & 7 & 30 \\ \text { Range } & <1-15 & 34-76 & 5-27 & <1-53 & 15-86 & <1-18 & <1-21 & 19-38\end{array}$

Agropyron spicatum/Agropyron smithii h.t. (9)

$\begin{array}{lcccccccc}\text { Mean } & 5 & 42 & 20 & 15 & 36 & 13 & 18 & 30 \\ \text { Range } & 0-13 & 27-56 & 4-66 & 2-73 & 17-68 & <1-70 & <132 & 17-42\end{array}$

AGSP/AGSM, Stipa viridula phase (7)

$\begin{array}{lcccccccc}\text { Mean } & 8 & 49 & 24 & 9 & 44 & 17 & 9 & 35 \\ \text { Range } & 0-23 & 27-76 & 12-34 & <1-14 & 18-82 & 1-63 & 1-23 & 28-44\end{array}$

Agropyron spicatum/Poa sandbergii (MONT.) h.t. (8)

$\begin{array}{lcccccccc}\text { Mean } & 6 & 58 & 17 & 24 & 53 & 23 & 12 & 26 \\ \text { Range } & 0-24 & 42-69 & 3-31 & <1-63 & 38-64 & 3-59 & 1-30 & 17-39\end{array}$

AGSP/POSAN (MONT.), Stipa comata phase (9)

$\begin{array}{lcccccccc}\text { Mean } & 5 & 52 & 20 & 17 & 47 & 11 & 12 & 30 \\ \text { Range } & <1-13 & 24-72 & <1-44 & 1-59 & 14-81 & <1-56 & 0-22 & 17-44\end{array}$

Festuca scabrella/Agropyron spicatum h.t. (25)

$\begin{array}{lcccccccc}\text { Mean } & 2 & 67 & 30 & 21 & 62 & 5 & 5 & 35 \\ \text { Range } & 0-20 & 27-90 & 12-47 & 2-63 & 14-90 & <1-23 & 0-24 & 20-52\end{array}$

EESC/AGSP, Stipa comata phase (21)

$\begin{array}{lcccccccc}\text { Mean } & 7 & 66 & 21 & 14 & 65 & 5 & 5 & 36 \\ \text { Range } & <1-57 & 39-94 & <7-40 & 1-57 & 12-92 & 0-19 & 0-15 & 27-48\end{array}$

Eestuca scabrella/Eestuca idahoensis h.t. (17)

$\begin{array}{lrccccrrc}\text { Mean } & 1 & 80 & 27 & 16 & 72 & 1 & 1 & 33 \\ \text { Range } & 0-8 & 48-92 & 9-64 & 0-67 & 17-95 & 0-8 & 0-3 & 16-44\end{array}$

FESC/EEID, Geranium viscosissimum phase (12)

$\begin{array}{lcccccccc}\text { Mean } & 2 & 73 & 47 & 22 & 68 & 3 & 1 & 40 \\ \text { Range } & 0-25 & 38-90 & 18-68 & 0-91 & 29-87 & 0-22 & 0-7 & 31-63\end{array}$


APPENDIX D (con.)

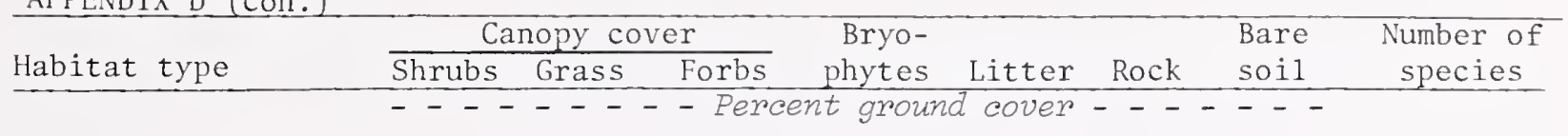

FESC/EEID, Stipa richardsonii phase (15)

$\begin{array}{lcccccccc}\text { Mean } & 2 & 87 & 32 & 12 & 78 & <1 & 1 & 32 \\ \text { Range } & 0-14 & 69-95 & 6-69 & <1-38 & 30-97 & 0-1 & 0-3 & 16-50\end{array}$

Festuca idahoensis/Agropyron smithii h.t. (10)

$\begin{array}{lcccccccc}\text { Mean } & 3 & 67 & 33 & 14 & 64 & 5 & 3 & 27 \\ \text { Range } & 0-10 & 48-83 & 1-67 & 4-28 & 14-90 & <1-18 & <1-8 & 15-42\end{array}$

Festuca idahoensis/Agropyron spicatum h.t. (45)

$\begin{array}{lcccccccc}\text { Mean } & 4 & 62 & 28 & 16 & 46 & 8 & 5 & 33 \\ \text { Range } & 0-15 & 25-86 & 10-55 & <1-62 & 9-94 & 0-40 & 0-25 & 22-50\end{array}$

FEID/AGSP, Stipa occidentalis phase (15)

$\begin{array}{lrccccccc}\text { Mean } & 1 & 69 & 48 & 8 & 55 & 5 & 2 & 38 \\ \text { Range } & 0-6 & 42-90 & 32-63 & <1-34 & 14-88 & <1-16 & <1-7 & 17-54\end{array}$

Festuca idahoensis/Carex filifolia h.t. (4)

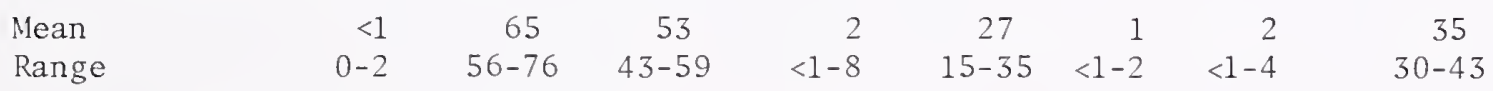

Festuca idahoensis/Stipa michardsonii h.t. (3)

$\begin{array}{lrccccccc}\text { Mean } & 4 & 79 & 49 & 7 & 84 & <1 & 1 & 35 \\ \text { Range } & 0-9 & 73-84 & 34-57 & <1-19 & 83-85 & <1 & <1-2 & 31-42\end{array}$

Festuca idahoensis/Agropyron caninum h.t. (9)

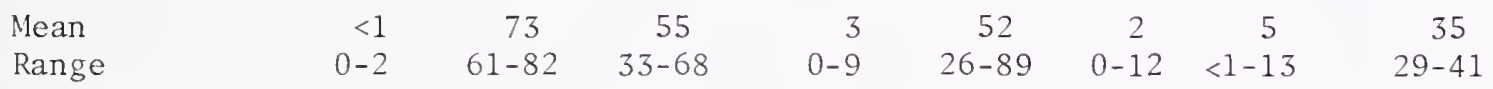

FEID/AGCA, Geranium viscosissimum phase (7)

$\begin{array}{lrccccccc}\text { Mean } & <1 & 77 & 58 & <1 & 51 & <1 & 3 & 40 \\ \text { Range } & 0-2 & 65-89 & 39-72 & 0-1 & 35-94 & <1 & <1-6 & 28-46\end{array}$

Festuca idahoensis/Deschampsia caespitosa h.t. (8)

$\begin{array}{lcccccccc}\text { Mean } & <1 & 66 & 50 & 7 & 36 & 2 & 3 & 28 \\ \text { Range } & 0-<1 & 26-82 & 25-70 & <1-19 & 18-84 & 0-7 & 0-14 & 20-35\end{array}$

Deschompsia caespitosa/Carex spp. h.t. (6)

$\begin{array}{lrccccccc}\text { Mean } & 1 & 88 & 34 & 16 & 76 & -- & <1 & 19 \\ \text { Range } & 0-4 & 82-92 & <1-57 & 8-26 & 23-92 & -- & 0-<1 & 12-27\end{array}$

Artemisia arbuscula/Agropyron spicatum h.t. (3)

$\begin{array}{lcccrcrcc}\text { Mean } & 20 & 42 & 17 & 5 & 40 & 23 & 15 & 23 \\ \text { Range } & 14-26 & 25-65 & 13-20 & 3-9 & 26-49 & 17-32 & 13-18 & 21-27\end{array}$

ARAR/AGSP, Stipa comata phase (3)

$\begin{array}{lcccccccc}\text { Mean } & 26 & 24 & 6 & 25 & 23 & 21 & 20 & 23 \\ \text { Range } & 21-32 & 22-27 & 2-10 & 3-51 & 13-30 & 10-24 & 9-32 & 21-25\end{array}$

Artemisia arbuscula/Eestuca idahoensis h.t. (2)

$\begin{array}{lcccccccc}\text { Mean } & 14 & 60 & 36 & 28 & 46 & 15 & 5 & 34 \\ \text { Range } & 8-21 & 44-75 & 13-60 & 9-46 & 24-69 & 7-22 & 2-8 & 32-37\end{array}$


APPENDTX D (con.)

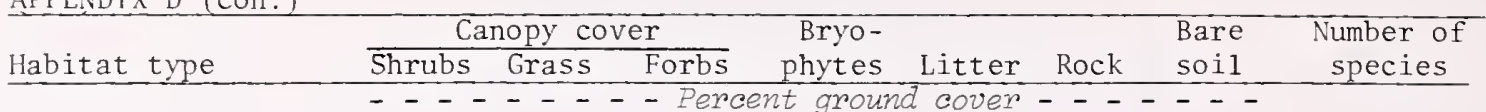

Artemisia tridentata/Agropyron spicatum (MONT.) h.t. (6)

$\begin{array}{lcccccccc}\text { Mean } & 18 & 41 & 6 & 9 & 42 & 32 & 11 & 21 \\ \text { Range } & 5-31 & 24-60 & <1-18 & 2-19 & 16-66 & 4-62 & 2-19 & 12-31\end{array}$

Artemisia tridentata/Festuca scabrella h.t. (6)

$\begin{array}{lcccccccc}\text { Mean } & 22 & 53 & 20 & 12 & 69 & 16 & 4 & 31 \\ \text { Range } & 6-35 & 28-79 & 13-28 & 5-23 & 44-84 & <1-43 & 0-12 & 23-40\end{array}$

Artemisia tridentata/Festuca idahoensis (MONT.) h.t. (3)

$\begin{array}{lcccccccc}\text { Mean } & 21 & 52 & 27 & 22 & 61 & 7 & 3 & 32 \\ \text { Range } & 5-44 & 20-78 & 5-62 & 11-56 & 23-82 & <1-23 & <1-9 & 17-42\end{array}$

ARTR/FEID (MONT.), Geranium viscosissimum phase (4)

$\begin{array}{lcccccccc}\text { Mean } & 24 & 87 & 60 & 1 & 80 & 1 & 1 & 41 \\ \text { Range } & 4-41 & 74-92 & 55-67 & <1-3 & 37-95 & <1-2 & <1-2 & 38-44\end{array}$

Artemisia tripartita/Festuca idahoensis (MONT.) h.t. (5)

$\begin{array}{lcccccccc}\text { Mean } & 23 & 84 & 32 & 6 & 80 & 7 & 4 & 26 \\ \text { Range } & 12-31 & 78-94 & 13-46 & 0-17 & 64-96 & 0-25 & <1-11 & 14-41\end{array}$

Rhus trizobata/Agropyron spicatum h.t. (4)

$\begin{array}{lcccccccc}\text { Mean } & 25 & 49 & 9 & 2 & 55 & 53 & 10 & 22 \\ \text { Range } & 3-60 & 32-60 & 6-11 & <1-3 & 39-69 & 29-74 & <1-18 & 19-25\end{array}$

Rhus trilobata/Festuca idahoensis h.t. (1)

$\begin{array}{lllllllll}\text { Mean } & 16 & 45 & 16 & 53 & 56 & 4 & 1 & 45 \\ \text { Range } & -- & -- & -- & -- & -- & -- & -- & --\end{array}$

Potentilla fmiticosa/Festuca scabrella h.t. (5)

$\begin{array}{lcccccccc}\text { Mean } & 16 & 61 & 30 & 9 & 66 & 19 & 4 & 48 \\ \text { Range } & 10-31 & 48-73 & 20-42 & <1-16 & 38-83 & <1-55 & <1-9 & 44-53\end{array}$

POFR/EESC, Danthonia intermedia phase (6)

$\begin{array}{lcccccccc}\text { Mean } & 26 & 76 & 42 & 8 & 87 & <1 & <1 & 45 \\ \text { Range } & 8-61 & 60-94 & 19-67 & 0-43 & 80-97 & 0-1 & 0-<1 & 28-59\end{array}$

Potentirla fmuticosa/Festuca idahoensis h.t. (4)

$\begin{array}{lcccccccc}\text { Mean } & 11 & 78 & 49 & 10 & 78 & 5 & 1 & 35 \\ \text { Range } & 3-25 & 68-87 & 31-74 & 4-16 & 70-83 & <1-14 & <1-3 & 25-47\end{array}$

Purshia tridentata/Agropyron spicatum (MONT.) h.t. (1)

$\begin{array}{lcccccccc}\text { Mean } & 2 & 60 & 22 & 14 & 77 & 39 & 6 & 21 \\ \text { Range } & -- & -- & -- & -- & -- & -- & -- & --\end{array}$

Purshia tridentata/Festuca scabrella h.t. (4)

$\begin{array}{lcccccccc}\text { Mean } & 19 & 71 & 26 & 35 & 75 & 12 & 4 & 32 \\ \text { Range } & 9-28 & 63-77 & 14-36 & 6-74 & 69-82 & 7-17 & <1-11 & 24-37\end{array}$

Cercocarpus ledifolius/Agropyron spicatum h.t. (1)

$\begin{array}{lrrrrrrrr}\text { Mean } & 27 & 17 & 3 & 26 & 35 & 45 & 8 & 24 \\ \text { Range } & -- & -- & -- & -- & -- & -- & -- & --\end{array}$

Sarcobatus vermiculatus/Agropyron smithii h.t. (1)

$\begin{array}{lrrrrrrrr}\text { Mean } & 8 & 54 & 1 & 1 & 52 & <1 & 19 & 4 \\ \text { Range } & -- & -- & -- & -- & -- & -- & -- & -\end{array}$




\section{APPENDIX E -}

\section{SPECIES CONSTANCY AND CANOPY COVER BY HABITAT TYPE}

Each table gives the constancy and canopy cover for all habitat types and phases within a climax series. Tables show constancy (in paraentheses), and canopy cover averaged over all stands within a habitat type or phase. The number of stands sampled appears in parentheses in the box heading under each habitat type or phase name. 



\section{E1. - Stipa comata Series}

Species constancy (in parentheses) and canopy cover for important species in the Stipa comata,Bouteloua gracilis h.t. (STCO/BOGR), and in the Agropyron smithii phase (AGSM) of this habitat type

Species
STCO/BOGR h.t.
AGSM phase
(19tands)

Medium Shrubs

Chrysothomnus nauseosus

Chrysothommus viscidifloms

Low Shrubs
(57)

(14)
(16)

( 5) p

$$
\begin{aligned}
& \text { Artemisia fmigida } \\
& \text { Eurotia lanata } \\
& \text { Gutierrezia sarothrae } \\
& \text { Opuntia polyacantha }
\end{aligned}
$$

Graminoids

$\begin{array}{rr}(71) & 1 \\ (100) & p \\ (100) & 1 \\ (100) & 2\end{array}$

(57)

(86)<smiles>[CH]C</smiles>

$(86)$

(86)

(29)

(29)

(86)

(100) 33

(16) 1

Forbs

Astragalus purshii

Chrysopsis viziosa

Gaura coccinea

Hymenoxys acaulis

Lepidium spp.

Liatris punctata

Iygodesmia juncea.

Melilotus officinalis

Paronychia sessiziflora

Phlox hoodii

Senecio canus

Sphaeralcea coccinea

Taraxacum officinale

The lesperma marginatum

Tragopogon dubius

Vicia omemicana

$\begin{array}{rr}(57) & p \\ (14) & p \\ (14) & p \\ -- & \\ (29) & p \\ -- & \\ -- & \\ -- & \\ -- & \\ (43) & 1 \\ -- & \\ (100) & p \\ (29) & p \\ -- & \\ (43) & p \\ -- & \end{array}$




\section{E2. - Agropyron spicatum Series}

Species constancy (in parentheses) and average canopy cover for important species in the following habitat types within the Agropyron spicatum series: Agropyron spicatum/Bouteloua gracilis h.t. (AGSP/BOGR), with Liatris punctata phase (LIPUN); A. spicatum/Agropyron smithii h.t. (AGSP/AGSM), with Stipa viridula phase (STVI); and A. spicatum/Poa sandbergii (MONT.) h.t. (AGSP/POSAN), with Stipa comata phase (STCO)

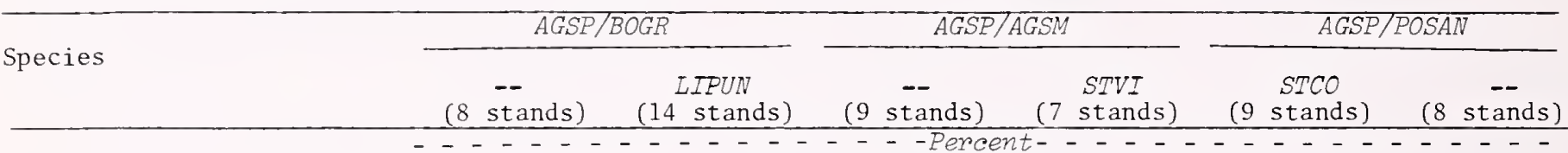

Medium Shrubs

$\begin{array}{lcccccc}\text { Artemisia cana } & -- & & -- & & -- & \\ \text { Artemisia tridentata } & (25) & \mathrm{p} & (6) & \mathrm{p} & (22) & \mathrm{p} \\ \text { Chmysothammus nauseosus } & (63) & \mathrm{p} & (21) & \mathrm{p} & (67) & 1 \\ \text { Chmysothommus viscidifloms (44) } & \mathrm{p} & (7) & \mathrm{p} & (33) & \mathrm{p} \\ \text { Junipemus scopulomm } & -- & & -- & & -- & \\ \text { Rhus trizobata } & -- & & -- & & (11) & \mathrm{p} \\ \text { Rosa arkansana } & (13) & \mathrm{p} & \text { (21) } & 1 & \text { (11) } & \mathrm{p}\end{array}$

Low Shrubs

Artemisia dracunculus
Artemisia frigida
Eurotia Zanata
Gutierrezia sarothrae
Leptodactylon pungens
Opuntia polyacantha
Iucca glauca

$\begin{array}{rrrr}(50) & \mathrm{p} & (21) & \mathrm{p} \\ (100) & 6 & (100) & 5 \\ -- & & (14) & \mathrm{p} \\ (100) & 2 & (64) & \mathrm{p} \\ (11) & \mathrm{p} & -- & \\ (75) & 1 & (57) & \mathrm{p} \\ (13) & \mathrm{p} & (21) & \mathrm{p}\end{array}$

$\begin{array}{cc}-- & \\ (89) & 2 \\ (11) & p \\ (89) & 1 \\ -- & \\ (22) & p\end{array}$

$\begin{array}{rr}(14) & \mathrm{p} \\ (100) & 5\end{array}$

(29) $\mathrm{p}$

(29) $\mathrm{p}$

29) $\mathrm{p}$

(14) p

(14) $\mathrm{p}$

(29) $\mathrm{p}$

(22) $\mathrm{p}$

(33) $\mathrm{p}$

(11) 1

(22) $\mathrm{p}$

(22) $\mathrm{p}$

(25) $\mathrm{p}$

(50) $\mathrm{p}$

(38) 1

(13) $\mathrm{p}$

(25) 1

(13) $\mathrm{p}$

Graminoids

\begin{tabular}{|c|c|c|c|}
\hline Agropyron dasystachyum & -- & & (14) \\
\hline Agropyron smithii & -- & & $(21)$ \\
\hline Agropyron spicatum & $(100)$ & 16 & $(100)$ \\
\hline Aristida Zongiseta & -- & & (14) \\
\hline Bouteloua gracilis & $(100)$ & 8 & $(100)$ \\
\hline Bromus japonicus & $(11)$ & $\mathrm{p}$ & (14) \\
\hline Bromus molizis & -- & & $(7)$ \\
\hline Bromus tectorum & (13) & $\mathrm{p}$ & (21) \\
\hline Calamagrostis montanensis & -- & & $(36)$ \\
\hline Carex fizifolia & -- & & (71) \\
\hline Carex stenophyzza & $(88)$ & 2 & $(86)$ \\
\hline Festuca idahoensis & -- & & -- \\
\hline Eestuca octoflora & -- & & -- \\
\hline Festuca scabrezla & -- & & -- \\
\hline Helictotrichon hookeri & -- & & -- \\
\hline Koeleria cristata & $(63)$ & 3 & $(100)$ \\
\hline Muhzenbergia cuspidata & -- & & $(29)$ \\
\hline Oryzopsis hymenoides & (13) & $\mathrm{p}$ & -- \\
\hline Poa cusickii & - & & $(36)$ \\
\hline Poa pratensis & -- & & -- \\
\hline Poa sandbergii & $(100)$ & 2 & $(86)$ \\
\hline Stipa comata & $(100)$ & 8 & $(100)$ \\
\hline Stipa viridula & -- & & $(21)$ \\
\hline Stipa spartea & -- & & -- \\
\hline
\end{tabular}

$\begin{array}{ccrrrrrr}-- & & (14) & \mathrm{p} & (56) & 2 & (14) & 3 \\ -- & & (21) & 2 & (44) & 1 & (86) & 4 \\ (100) & 16 & (100) & 25 & (100) & 18 & (100) & 16 \\ -- & & (14) & \mathrm{p} & (11) & \mathrm{p} & (29) & 1 \\ (100) & 8 & (100) & 5 & (22) & \mathrm{p} & (29) & \mathrm{p} \\ (11) & \mathrm{p} & (14) & \mathrm{p} & -- & & (14) & \mathrm{p} \\ -- & & (7) & \mathrm{p} & -- & & -- & \\ (13) & \mathrm{p} & (21) & \mathrm{p} & (22) & \mathrm{p} & (57) & \mathrm{p} \\ -- & & (36) & \mathrm{p} & (44) & \mathrm{p} & (14) & \mathrm{p} \\ -- & & (71) & 3 & (11) & 1 & (29) & 1 \\ (88) & 2 & (86) & 1 & (78) & 2 & (86) & 1 \\ -- & & -- & & (11) & \mathrm{p} & -- & \\ -- & & -- & & -- & & -- & \\ -- & & -- & & (11) & \mathrm{p} & (14) & \mathrm{p} \\ -- & & -- & & (11) & 2 & -- & \\ (63) & 3 & (100) & 7 & (100) & 8 & (100) & 7 \\ -- & & (29) & 1 & (11) & \mathrm{p} & -- & \\ (13) & \mathrm{p} & -- & & -- & & -- & \\ -- & & (36) & 1 & (67) & 3 & (57) & 4 \\ -- & & -- & & -- & & -- & \\ (100) & 2 & (86) & 1 & (78) & 3 & (71) & 3 \\ (100) & 8 & (100) & 11 & (100) & 6 & (86) & 4 \\ -- & & (21) & 2 & -- & & (100) & 6 \\ -- & & -- & & -- & -- & \end{array}$

$\begin{array}{cc}(22) & p \\ (89) & 2 \\ (22) & 1 \\ (56) & 1 \\ -- & \\ (44) & p \\ -- & \end{array}$

(25) $\mathrm{p}$

(88) 2

(38) 2

(100) 3

(57) $\mathrm{p}$

(38) $\mathrm{p}$

\begin{tabular}{|c|c|c|}
\hline-- & & -- \\
\hline -- & & -- \\
\hline$(100)$ & 20 & $(100)$ \\
\hline (1 11$)$ & 1 & $(25)$ \\
\hline (22) & $\mathrm{p}$ & - \\
\hline-- & & -- \\
\hline (11) & $\mathrm{p}$ & (13) \\
\hline (33) & 1 & (38) \\
\hline (11) & 1 & (13) \\
\hline (22) & 2 & -- \\
\hline-- & & (13) \\
\hline-- & & (13) \\
\hline$(22)$ & $\mathrm{p}$ & (13) \\
\hline (22) & $\mathrm{p}$ & (25) \\
\hline-- & & -- \\
\hline $\begin{array}{c}(89) \\
--\end{array}$ & 5 & $\begin{array}{c}(75) \\
--\end{array}$ \\
\hline (11) & p & (38) \\
\hline (11) & $\mathrm{p}$ & (13) \\
\hline$(22)$ & $\mathrm{p}$ & (13) \\
\hline$(100)$ & 3 & (75) \\
\hline (89) & 19 & -- \\
\hline (11) & 1 & -- \\
\hline (11) & $\mathrm{p}$ & -- \\
\hline
\end{tabular}

(Con.) 
APPENDIX E2 (con.)

\begin{tabular}{|c|c|c|c|c|c|c|c|c|c|c|c|c|}
\hline \multirow[b]{2}{*}{ Species } & \multicolumn{4}{|c|}{$A G S P / B O G R$} & \multicolumn{4}{|c|}{ AGSP/AGSM } & \multicolumn{4}{|c|}{$A G S P / P O S A N$} \\
\hline & \multicolumn{2}{|c|}{ (8 stands) } & \multicolumn{2}{|c|}{$\begin{array}{c}\text { LIPUN } \\
(14 \text { stands) } \\
\end{array}$} & \multicolumn{2}{|c|}{$\left(\begin{array}{c}-- \\
(9 \\
\text { stands }\end{array}\right)$} & \multicolumn{2}{|c|}{$\begin{array}{c}\text { STVI } \\
(7 \text { stands }) \\
\end{array}$} & \multicolumn{2}{|c|}{$\begin{array}{c}\text { STCO } \\
(9 \text { stands }) \\
\end{array}$} & \multicolumn{2}{|c|}{ (8 stan } \\
\hline & -- & $-\cdots$ & - & --- & -- & - Per & $t--$ & $-\cdots$ & $-\cdots$ & & $-\cdots$ & - \\
\hline \multicolumn{13}{|l|}{ Forbs } \\
\hline Achilzea millefolium & -- & & (29) & $\mathrm{p}$ & $(44)$ & $\mathrm{p}$ & (43) & $\mathrm{p}$ & $(56)$ & 1 & $(75)$ & \\
\hline Agoseris grauca & -- & & $(7)$ & $\mathrm{p}$ & -- & & (29) & $\mathrm{p}$ & -- & & (13) & \\
\hline AlZirom cemuum & (11) & $\mathrm{p}$ & (50) & $\mathrm{p}$ & $(67)$ & 1 & (29) & $\mathrm{p}$ & (33) & $\mathrm{p}$ & $(25)$ & \\
\hline Antennaria dimorpha & -- & & -- & & (22) & $\mathrm{p}$ & (14) & $\mathrm{p}$ & (22) & $\mathrm{p}$ & (13) & \\
\hline Antennamia pamifolia & $(25)$ & $\mathrm{p}$ & $(7)$ & $\mathrm{p}$ & (44) & $\mathrm{p}$ & (14) & $\mathrm{p}$ & (11) & $\mathrm{p}$ & - & \\
\hline Antennaria rosea & (13) & $\mathrm{p}$ & (29) & $\mathrm{p}$ & (44) & $\mathrm{p}$ & $(28)$ & $\mathrm{p}$ & (33) & $\mathrm{p}$ & $(38)$ & \\
\hline Arabis holboellii & (25) & $\mathrm{p}$ & (7) & $\mathrm{p}$ & (44) & $\mathrm{p}$ & (28) & $\mathrm{p}$ & (33) & $\mathrm{p}$ & $(50)$ & \\
\hline Arenaria congesta &.-- & & $(7)$ & $\mathrm{p}$ & $(22)$ & $\mathrm{p}$ & (14) & $\mathrm{p}$ & (11) & $\mathrm{p}$ & $(25)$ & \\
\hline Artemisia Zudoviciana & -- & & (29) & 1 & $=-$ & & $(43)$ & 1 & (11) & $\mathrm{p}$ & $\because-$ & \\
\hline Aster falcatus & -- & & (14) & $\mathrm{p}$ & (11) & $\mathrm{p}$ & $(43)$ & 1 & (11) & $\mathrm{p}$ & - & \\
\hline Aster scopulomm & $(25)$ & $\mathrm{p}$ & -- & & (11) & $\mathrm{p}$ & (29) & $\mathrm{p}$ & -- & & -- & \\
\hline Astragalus drumondii & - & & $(7)$ & $\mathrm{p}$ & (11) & $\mathrm{p}$ & (29) & $\mathrm{p}$ & $(22)$ & 1 & -- & \\
\hline Astragalus miser & -- & & $\ldots$ & & - & & -- & & (33) & 1 & $(25)$ & \\
\hline Astragalus purshii & (13) & $\mathrm{p}$ & (14) & $\mathrm{p}$ & $(44)$ & $\mathrm{p}$ & $(43)$ & $\mathrm{p}$ & $(56)$ & 1 & -- & \\
\hline Balsomorhiza ineo & -- & & -- & & -- & & (29) & 1 & -- & & -- & \\
\hline Balscomorhizas & -- & & -- & & -- & & -- & & (44) & 3 & (25) & \\
\hline Besse & -- & & (14) & $\mathrm{p}$ & (11) & $\mathrm{p}$ & (29) & $\mathrm{p}$ & (11) & $\mathrm{p}$ & (13) & \\
\hline ium arvense & -- & & $(7)$ & $\mathrm{p}$ & $(22)$ & $\mathrm{p}$ & (14) & $\mathrm{p}$ & $(22)$ & 1 & (13) & \\
\hline Chrysopsis vilzosa & $(38)$ & $\mathrm{p}$ & (79) & 1 & (67) & 1 & $(86)$ & 3 & (56) & 2 & (50) & \\
\hline Cirsium undulatum & -- & & (29) & $\mathrm{p}$ & (11) & $\mathrm{p}$ & -- & & (33) & $\mathrm{p}$ & (25) & \\
\hline Colzinsia pamiflora & -- & & - - & & -- & & -- & & (11) & $\mathrm{p}$ & (13) & \\
\hline Colzomia linearis & -- & & -- & & -- & & -- & & (11) & $\mathrm{p}$ & (25) & \\
\hline Comandra umbellata & -- & & $(21)$ & $\mathrm{p}$ & $(22)$ & $\mathrm{p}$ & $(43)$ & 1 & $(67)$ & 1 & $(50)$ & \\
\hline Crepis occidentalis & -- & & (21) & $\mathrm{p}$ & $(33)$ & $\mathrm{p}$ & (43) & $\mathrm{p}$ & - & & (25) & \\
\hline Cryptantha celosioides & (11) & $\mathrm{p}$ & (29) & $\mathrm{p}$ & (22) & $\mathrm{p}$ & (29) & $\mathrm{p}$ & $(56)$ & $\mathrm{p}$ & -- & \\
\hline Draba vema & -- & & -- & & -- & & -- & & (11) & $\mathrm{p}$ & $(50)$ & \\
\hline Epizobium minutum & -- & & -- & & +- & & -- & & $(22)$ & $\mathrm{p}$ & (25) & \\
\hline Erigeron caespitosus & -- & & $(43)$ & $\mathrm{p}$ & $(44)$ & $\mathrm{p}$ & $(43)$ & 1 & (33) & $\mathrm{p}$ & (13) & \\
\hline Emigeron compositus & $(25)$ & $\mathrm{p}$ & -- & & (44) & $\mathrm{p}$ & (29) & 1 & (44) & $\mathrm{p}$ & (13) & \\
\hline Erigeron filifolius & $(38)$ & $\mathrm{p}$ & $(21)$ & $\mathrm{p}$ & $(22)$ & $\mathrm{p}$ & (29) & $\mathrm{p}$ & (22) & $\mathrm{p}$ & -- & \\
\hline Erigeron pumilis & -- & & $(7)$ & $\mathrm{p}$ & -- & & -- & & $(22)$ & $\mathrm{p}$ & $(25)$ & \\
\hline Eriogonum flavrom & -- & & - & & $(22)$ & $\mathrm{p}$ & (14) & $\mathrm{p}$ & $(22)$ & $\mathrm{p}$ & $(25)$ & \\
\hline Emiogonum microthecum & $(63)$ & $\mathrm{p}$ & -- & & - & & -- & & (22) & $\mathrm{p}$ & (50) & \\
\hline Emiogonum ovalifolium & -- & & (7) & & (11) & $\mathrm{p}$ & (29) & $\mathrm{p}$ & -- & & -- & \\
\hline Gailiardia aristata & -- & & (21) & $\mathrm{p}$ & -- & & -- & & $(22)$ & $\mathrm{p}$ & $(25)$ & \\
\hline Faura coccinea & $(38)$ & $\mathrm{p}$ & $(57)$ & $\mathrm{p}$ & $(22)$ & $\mathrm{p}$ & $(43)$ & $\mathrm{p}$ & (56) & $\mathrm{p}$ & $(38)$ & \\
\hline n triflom & - & & -- & & (33) & $\mathrm{p}$ & -- & & -- & & $(25)$ & \\
\hline Hymenoxys a & - & & (19) & $\mathrm{p}$ & (22) & 1 & (29) & 1 & $(22)$ & $\mathrm{p}$ & -- & \\
\hline Lappula echinata & (13) & $\mathrm{p}$ & - & & - & & -- & & - & & -- & \\
\hline Lospula redowskit & - & & -- & & -- & & -- & & (11) & $\mathrm{p}$ & $(25)$ & \\
\hline Lesquerezla azpina & -- & & (14) & & (11) & & (29) & $\mathrm{p}$ & $(22)$ & $\mathrm{p}$ & -- & \\
\hline Lepidium spp. & $(38)$ & $\mathrm{p}$ & (21) & $\mathrm{p}$ & $(56)$ & 1 & (71) & 1 & -- & & (13) & \\
\hline Liatris punctata & -- & & $(93)$ & 1 & (22) & $\mathrm{p}$ & (43) & $\mathrm{p}$ & $(22)$ & $\mathrm{p}$ & (13) & \\
\hline Linum perenne & -- & & (29) & $\mathrm{p}$ & (33) & $\mathrm{p}$ & (14) & $\mathrm{p}$ & (44) & $\mathrm{p}$ & (13) & \\
\hline Lithospermum muderale & (13) & $\mathrm{p}$ & (14) & $\mathrm{p}$ & - & & (14) & $\mathrm{p}$ & (44) & $\mathrm{p}$ & (25) & \\
\hline Lomatizon cous & -- & & $(7)$ & $\mathrm{p}$ & -- & & (14) & $\mathrm{p}$ & (22) & $\mathrm{p}$ & - & \\
\hline Lomatium tritematum & -- & & - - & & (11) & $\mathrm{p}$ & - & & -- & & $(25)$ & \\
\hline Lupinus sericeus & -- & & $(7)$ & $\mathrm{p}$ & (11) & $\mathrm{p}$ & $(43)$ & $\mathrm{p}$ & (33) & $\mathrm{p}$ & (63) & \\
\hline Lygodesmia juncea & (13) & $\mathrm{p}$ & $(21)$ & $\mathrm{p}$ & - & & (14) & $\mathrm{p}$ & $(22)$ & $\mathrm{p}$ & -- & \\
\hline Oxytropis besseyi & (25) & $\mathrm{p}$ & (14) & 1 & -- & & (14) & $\mathrm{p}$ & - & & -- & \\
\hline Oxytropis sericea & (13) & $\mathrm{p}$ & (14) & $\mathrm{p}$ & -- & & (14) & $\mathrm{p}$ & $(22)$ & $\mathrm{p}$ & (13) & \\
\hline
\end{tabular}

(con.) 
APPENDIX E2 (con.

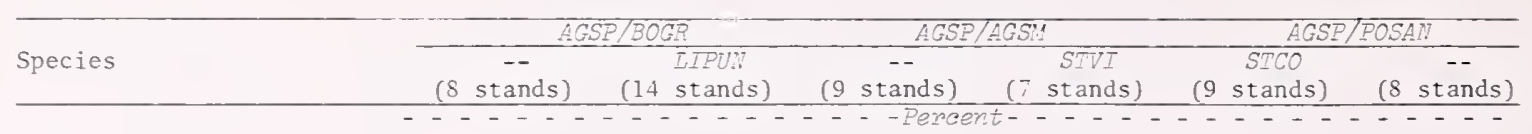

Forbs (con.)

Paronychia sessilitiora Phacelia hastata

Phlox hoodit

$-$

(14) $\mathrm{p}$

(11) 1

(29) p

(11) $\mathrm{p}$

plontago purshi

(75) 2

(93) 3

Po'̈yoon

(25) $\mathrm{p}$

Psoralea tenuiflora

Senecio canus

-.

(13)

(13) $\mathrm{p}$

(7) $\mathrm{p}$

(7)

(89) 6 (100) -

(67) 3

(11) $\mathrm{p}$ (29) $p$

(29) p

(36) 1

$-$

(29) p

--

solidaro missowmensis

Sphaeralcea coccinea

Taraxacum officinate

Thelasperma marginatum

Tragopogon dubius

(88) $p$ (21) $p$

(13) $\mathrm{p}$ (50) $\mathrm{p}$

(-) (29) p

icia amemicana

(29)

(35) p

(33) 1

(29) $\mathrm{p}$

(29)

(29) $\mathrm{p}$

(78) $\mathrm{p} \quad(86) \mathrm{p}$

(44) p (29)

--

(67) p (100)

(11) $\mathrm{p}$

$--$

$--$

(11) $\mathrm{p}$

(44) p

(11) $\mathrm{p}$

(44) $\mathrm{p}$

(22) $\mathrm{p}$

(89)

$(25)$

(38) 3

(25) $\mathrm{p}$

-- (29)

(86) 3

$-$

$--$

$--$

(25) p

(25) p

(38) p

(75)

(25) $\mathrm{p}$

${ }^{1} p=$ present with less than 0.5 percent canopy cover . 


\section{E3. - Festuca scabrella Series}

Species constancy (in parentheses) and average canopy cover for important species in the following habitat types within the Festuca scabrella series: Festuca scabrella/Agropyron spicatum h.t. (FESC/AGSP), with Stipa comata phase (STCO); and F. scabrelza/Festuca idahoensis h.t. (FESC/FEID), with Geranium viscosissimum (GEVI) and Stipa richardsonii (STRI) phases

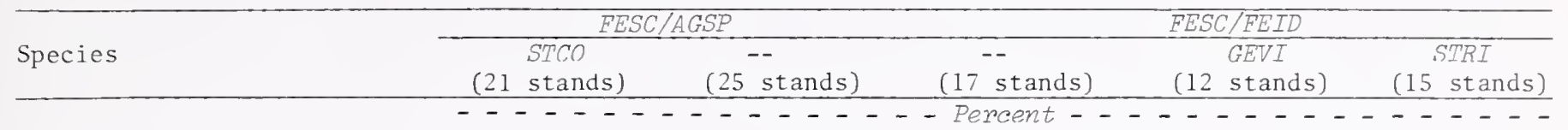

Medium shrubs

Rosa arkansana

Tetradymia canescens

(33) $\mathrm{p}^{1}$

(28) p

(18) $\mathrm{p}$

(8) 1

(53) 1

(24) p

(12) p

Low Shrubs

Artemisia compestris

Artemisia frigida

Gutierrezia sarothrae

$\begin{array}{rlrr}(10) & \mathrm{p} & -- & \\ (24) & \mathrm{p} & (8) & \mathrm{p} \\ (100) & 3 & (48) & 1 \\ (57) & \mathrm{p} & (16) & \mathrm{p}\end{array}$

Agropyron caninum

Agropyron dasystachyum

Acropuron smithii

Agropyron spicatum

Bouteloua gracizis

Bromus carinatus

Bromus japonicus

Bromus mozzis

Bromus tectomum

Calamagrostis montonensis

Carex fizifolia

carex obtusata

Carex petasata

Carex pennsyzuanica

Carex mpestmis

Carex scimpoidea

Carex stenophyzza

Carex valzicola

Danthonia intemedia

Danthonia parryi

Danthonia unispicata

Festuca idahoensis

Festuca scabrezla

Helictotmichon hookeri

Koeleria cristata

Mullenbergia cuspidata

Poa cusickii

Poa pratensis

Poa sandbergi $i$

Stipa comata

Stipa occidentalis

Stipa michardsonii

Stipa sparted

Stipa vimiduza
(10) $\mathrm{p}$

$\begin{array}{rr}(10) & p \\ -- & \\ (33) & 1 \\ (95) & 19 \\ (48) & 1 \\ -- & \\ (10) & p \\ -- & \\ (14) & p \\ (10) & p \\ (48) & 1 \\ (10) & 1 \\ (10) & p \\ (22) & 1 \\ -- & \\ -- & \\ (57) & 1 \\ -- & \\ -- & \\ (14) & p \\ (19) & p \\ (71) & 11 \\ (100) & 28 \\ (19) & p \\ (100) & 3 \\ (33) & 1 \\ (48) & p \\ (5) & p \\ (52) & 1 \\ (71) & 1 \\ -- & \\ -- & \\ (19) & p \\ (14) & p \\ & \\ (11\end{array}$

$\begin{array}{cc}(65) & 1 \\ (24) & 1 \\ (24) & 1 \\ (35) & p \\ -- & \end{array}$

(6) $\mathrm{p}$

(6) p

(6) $\mathrm{p}$

(41) $\mathrm{P}$

(47) 2

(47) 2

(41) 1

(29) 2

(6) 1

(24) 2

(6) 1

(41) 2

(18) 4

(18) p

(100) 15

(100) 54

(18) $\mathrm{p}$

(94) 2

(29) 1

(12) $\mathrm{p}$

(29) $\mathrm{p}$

$--$

(35) $\mathrm{p}$

(18) 1
(25)

(17) $\mathrm{p}$

$--$
--

$-$

$-$

\begin{tabular}{c}
$(25)$ \\
-- \\
$(8)$ \\
$(100)$ \\
-- \\
$(25)$ \\
-- \\
$(8)$ \\
-- \\
-- \\
$(17)$ \\
$(42)$ \\
$(67)$ \\
$(8)$ \\
$(8)$ \\
$(8)$ \\
-- \\
-- \\
$(67)$ \\
-- \\
$(25)$ \\
$(100)$ \\
$(100)$ \\
$(8)$ \\
$(10)$ \\
$(100)$ \\
-- \\
-- \\
$(42)$ \\
$(50)$ \\
-- \\
$(67)$ \\
-- \\
$(8)$ \\
$(33)$ \\
\\
\hline
\end{tabular}

(47)<smiles></smiles>

(7) $\quad \mathrm{p}$

(47)

(7) $\mathrm{p}$

$-$

$-$

$-$

(73) 10

(20) 1

(40) 1

(13) 2

(7) $\mathrm{p}$

(13) 1

(13) 1

(40) 2

(93) 5

$-$

(93) 11

(100) 59

(7) $\mathrm{p}$

(100) 1

--

(13) $\mathrm{p}$

(20) p

(47) 1

(93) 15

--

(con.) 


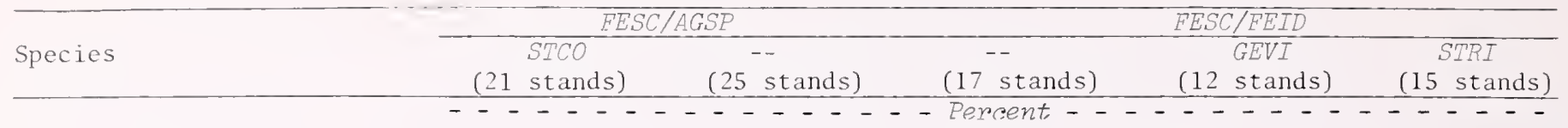

Forbs

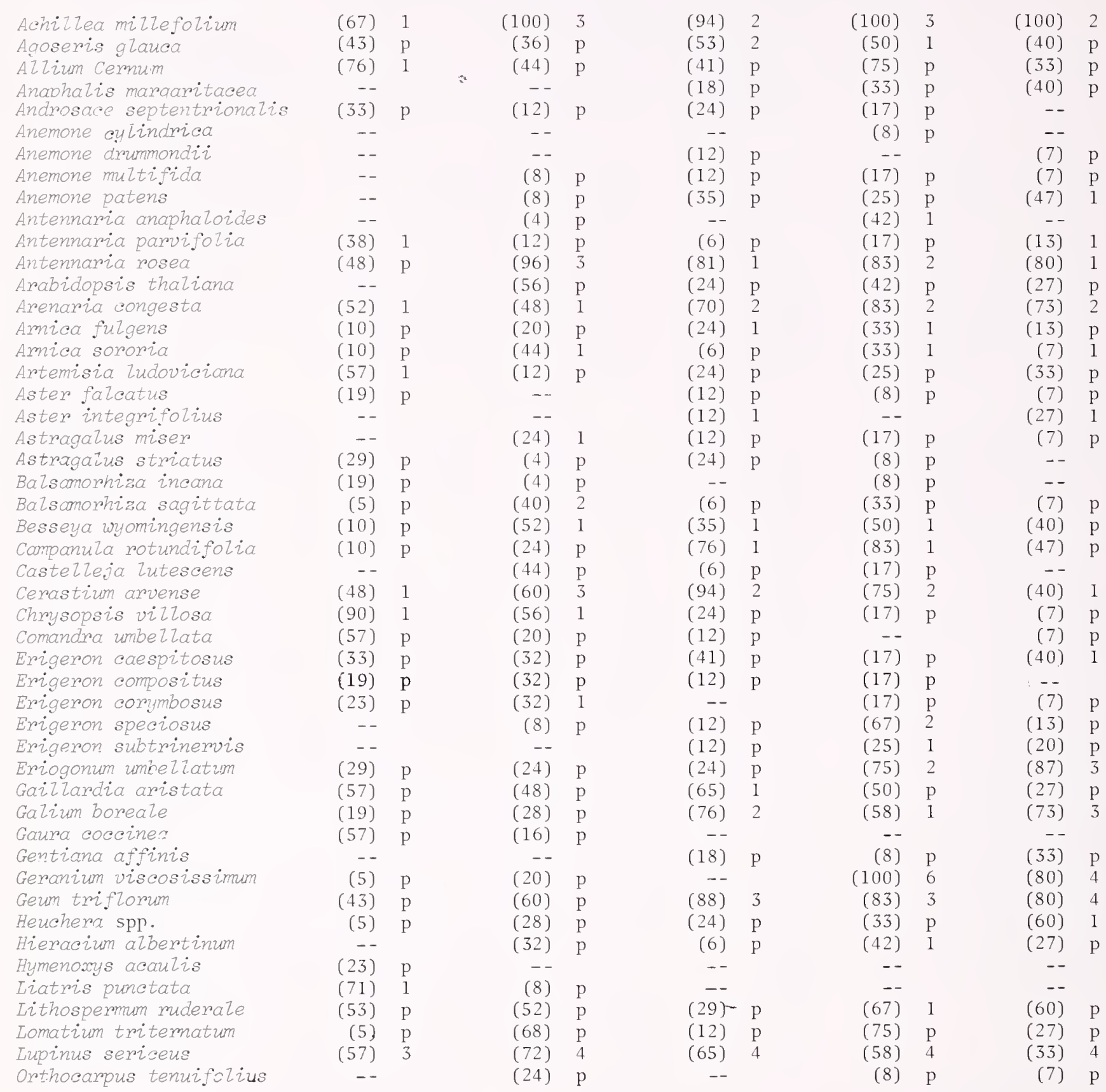

(con.) 
APPENDIX EJ (con.)

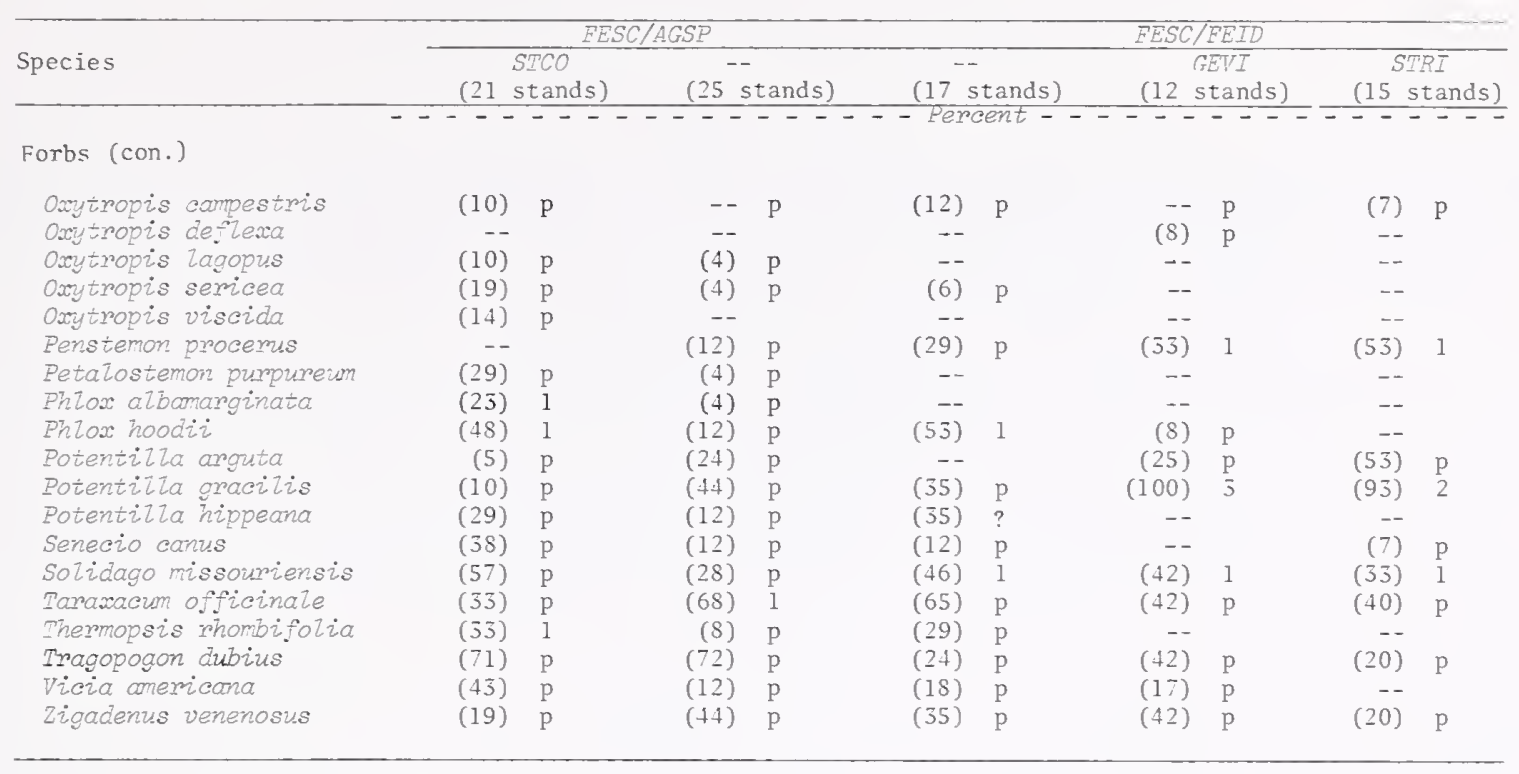

${ }^{1} p=$ present with less than 0.5 percent canopy cover. 


\section{E4. - Festuca idahoensis Series}

Species constancy (in parentheses) and average canopy cover for important species in the following habitat types within the Festuca idahoensis series: Festuca idahoensis/Agropyron smithii h.t. (FEID/AGSM); F. idahoensis/Agropyron spicatum h.t. (EEID/AGSP), with Stipa occidentalis phase (STOC); F. idahoensis/ Carex filifolia h.t. (FEID/CAFI); F. idahoensis/Stipa michardsonii h.t. (FEID/STRI); F. idahoensis/ Agropyron caninum h.t. (FEID/AGCA), with Geranium viscosissimum phase (GEVI); and F. idahoensis/ Deschompsia caespitosa h.t. (FEID/DECA)

\begin{tabular}{|c|c|c|c|c|c|c|c|c|}
\hline \multirow[b]{2}{*}{ Species } & \multirow{2}{*}{$\begin{array}{l}\text { FEID/AGSM } \\
-- \\
(10 \\
\text { stands) }\end{array}$} & \multicolumn{2}{|c|}{ FEID/AGSP } & \multirow{2}{*}{$\begin{array}{c}\text { FEID/CAFI } \\
\overline{(4} \\
\text { stands })\end{array}$} & \multirow{2}{*}{$\begin{array}{c}\text { FEID/ } \\
\text { STRI } \\
-- \\
(3 \\
\text { stands) }\end{array}$} & \multicolumn{2}{|c|}{ FEID/AGCA } & \multirow{2}{*}{$\begin{array}{c}\text { FEID } / D E C A \\
-- \\
(8 \\
\text { stands) }\end{array}$} \\
\hline & & $\begin{array}{c}-- \\
(45 \\
\text { stands) }\end{array}$ & $\begin{array}{c}\text { STOC } \\
(15 \\
\text { stands) }\end{array}$ & & & $\begin{array}{l}- \\
(9 \\
\text { stands) }\end{array}$ & $\begin{array}{c}\text { GEVI } \\
(7 \\
\text { stands) }\end{array}$ & \\
\hline
\end{tabular}

Medium Shrubs

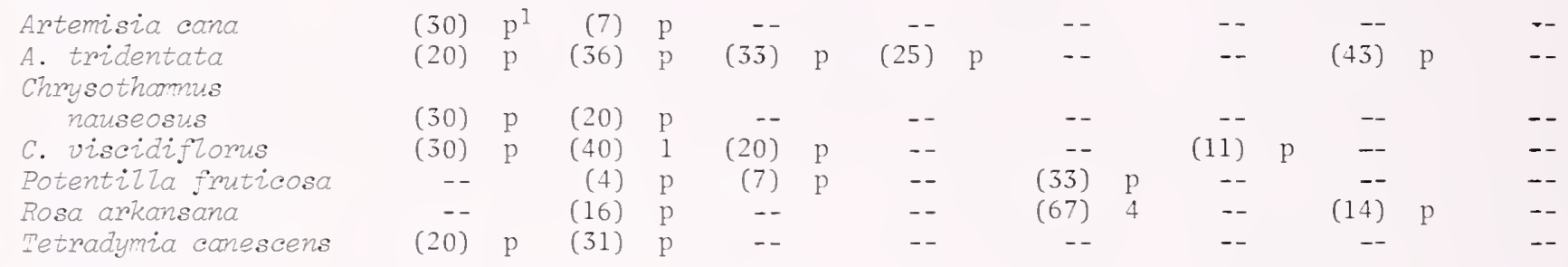

Low Shrubs

$\begin{array}{lllll}\text { Artemisia frigida } & \text { (90) } & 3 & \text { (84) } & 2 \\ \begin{array}{l}\text { Gutierrezia } \\ \text { sarothrae }\end{array} & \text { (10) } & \text { p } & \text { (31) } & \text { p }\end{array}$

Graminoids

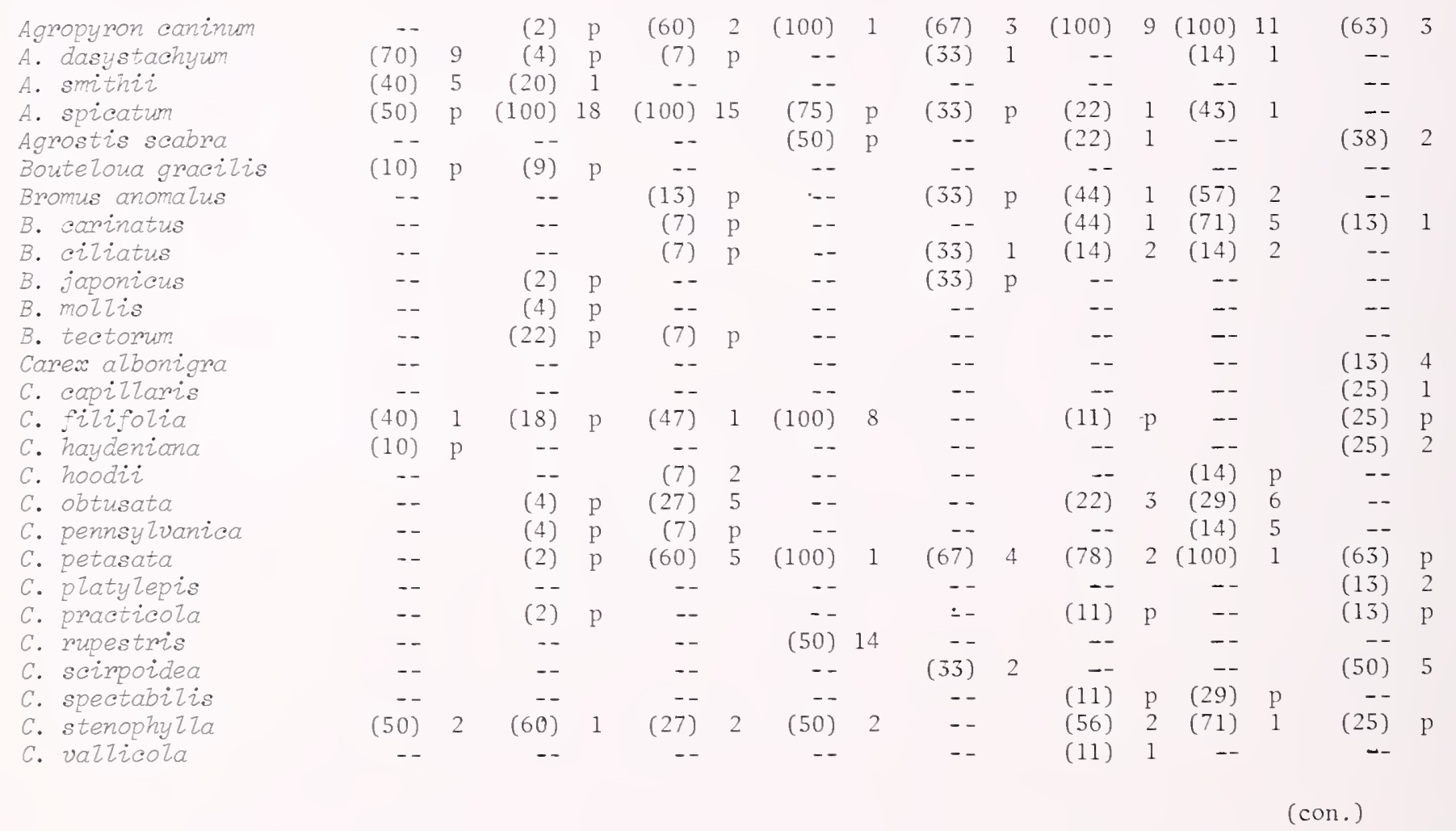


APPENDIX EA (con.)

\begin{tabular}{|c|c|c|c|c|c|c|c|c|}
\hline \multirow[b]{2}{*}{ Species } & \multirow{2}{*}{$\begin{array}{l}\text { EEID/AGSH } \\
\overline{(10} \\
\text { stands) }\end{array}$} & \multicolumn{2}{|c|}{ FEID/AGSP } & \multirow{2}{*}{$\begin{array}{c}\text { EEID/CAFI } \\
-\overline{(4} \\
\text { stands) }\end{array}$} & \multirow{2}{*}{$\begin{array}{l}\text { FEIDI } \\
\text { STRI } \\
\overline{(j} \\
\text { stands })\end{array}$} & \multicolumn{2}{|c|}{$E E I D / A G C A$} & FEID/DEC \\
\hline & & $\begin{array}{c}-\overline{-} \\
(45 \\
\text { stands) }\end{array}$ & $\begin{array}{l}\text { STOC } \\
(15 \\
\text { stands) }\end{array}$ & & & $\begin{array}{c}-- \\
(9 \\
\text { stands) }\end{array}$ & $\begin{array}{c}\text { GEVII } \\
(7 \\
\text { stands) }\end{array}$ & $\begin{array}{c}\overline{(8} \\
\text { stands) }\end{array}$ \\
\hline
\end{tabular}

Graminoids (con.)

\begin{tabular}{|c|c|c|c|c|c|c|c|c|c|c|c|c|c|c|c|c|}
\hline Danthonia intermedia & -- & & (4) & $\mathrm{p}$ & $(53)$ & 4 & $(100)$ & 10 & $(100)$ & 6 & (89) & 15 & $(86)$ & 4 & $(50)$ & 5 \\
\hline D. unispicata & $(10)$ & 1 & (9) & $\mathrm{p}$ & -- & & -- & & -- & & - & & - & & -- & \\
\hline Deschampsia caespitosa & -- & & -- & & -- & & -- & & -- & & -- & & -- & & (100) & 17 \\
\hline $\begin{array}{l}\text { Festuca idahoensis } \\
\text { F. scabrella }\end{array}$ & $\begin{array}{r}(100) \\
--\end{array}$ & 43 & $\begin{array}{r}(100) \\
(9)\end{array}$ & $\begin{array}{r}37 \\
p\end{array}$ & $\begin{aligned}(100) \\
--\end{aligned}$ & 31 & $\begin{array}{r}(100) \\
--\end{array}$ & 29 & $\begin{array}{r}(100) \\
(35)\end{array}$ & 12 & $\begin{array}{r}(100) \\
(11)\end{array}$ & $\begin{array}{r}36 \\
p\end{array}$ & $(100)$ & 24 & $\begin{aligned}(100) \\
--\end{aligned}$ & 21 \\
\hline 'uncus balticus & - & & -- & & - - & & -- & & - & & - & & - & & (13) & $\mathrm{p}$ \\
\hline T. tenuis & -- & & -- & & - - & & -- & & - & & -- & & -- & & (15) & \\
\hline Koelema cmistata & $(100)$ & 5 & $(98)$ & 4 & $(95)$ & 4 & $(50)$ & 1 & $(100)$ & $\mathrm{p}$ & $(100)$ & 4 & $(100)$ & 4 & $(38)$ & \\
\hline Luzula spicata & -- & & - - & & - & & $(50)$ & $\mathrm{p}$ & -- & & -- & & -- & & $(75)$ & \\
\hline Uelica bulbosa & - - & & -- & & $(7)$ & $\mathrm{p}$ & -- & & -- & & -- & & (29) & 1 & - & \\
\hline$\because$ spectabilis & -- & & -- & & - & & -- & & -- & & -- & & -- & & (13) & \\
\hline Phiewn & - - & & - - & & - - & & $=-$ & & -- & & -. & & - & & $(63)$ & \\
\hline P. pratense & - & & (9) & $\mathrm{p}$ & -- & & -- & & $(53)$ & $\mathrm{p}$ & (11) & $\mathrm{p}$ & (29) & 2 & -- & \\
\hline Poa cu & $(70)$ & 4 & $(22)$ & 1 & $(47)$ & 1 & -- & & (33) & $\mathrm{p}$ & $=-$ & & -- & & -- & \\
\hline P. Sendlemiana & - - & & - & & - & & $(50)$ & $\mathrm{p}$ & -- & & -- & & -- & & -- & \\
\hline P. intemon & -- & & -- & & (7) & $\mathrm{p}$ & $(50)$ & $\mathrm{p}$ & -- & & $(3 \overrightarrow{3})$ & $\mathrm{p}$ & $(43)$ & $\mathrm{p}$ & $(58)$ & 1 \\
\hline P. imeifolia & $(50)$ & $\mathrm{p}$ & $(4)$ & $\mathrm{p}$ & $(3 j)$ & $\mathrm{p}$ & $(25)$ & $\mathrm{p}$ & $(67)$ & 2 & $(22)$ & $\mathrm{p}$ & $(86)$ & & (25) & \\
\hline P. pratensis & (10) & $\mathrm{p}$ & (11) & $\mathrm{p}$ & - - & & -- & & (53) & $\mathrm{p}$ & -- & & (29) & 5 & -. & \\
\hline P. sandiergit & (30) & 4 & $(80)$ & 3 & $(47)$ & 1 & $(75)$ & $\mathrm{p}$ & - & & $(33)$ & 1 & -- & & $(38)$ & $\mathrm{p}$ \\
\hline Stipa & $(20)$ & $\mathrm{p}$ & $(60)$ & 3 & (13) & $\mathrm{p}$ & -- & & -- & & -- & & -- & & -- & \\
\hline S. ocei & -- & & $(7)$ & $\mathrm{p}$ & $(100)$ & 6 & -- & & $(100)$ & 15 & $(100)$ & 7 & (86) & z & (13) & 3 \\
\hline Cisonii & - - & & $\ldots$ & & (15) & $\mathrm{p}$ & -- & & $(100)$ & 36 & $(22)$ & $\mathrm{p}$ & $(45)$ & 2 & - & \\
\hline S. vimidula & - - & & (13) & $\mathrm{p}$ & - - & & -- & & (33) & 1 & -- & & - - & & -- & \\
\hline Thisetum spicatum & - - & & - - & & - & & (25) & $\mathrm{p}$ & - & & -- & & - - & & $(50)$ & \\
\hline T. wolfi & - - & & - - & & - - & & - & & -- & & -- & & -- & & (25) & \\
\hline
\end{tabular}

Forbs

\begin{tabular}{|c|c|c|c|c|c|c|c|c|c|c|c|c|c|c|c|}
\hline Achillea millefoirim & $(70)$ & 1 & $(82)$ & 1 & $(100)$ & 3 & $(100)$ & 4 & $(100)$ & 5 & $(100)$ & 5 & $(100)$ & 6 & $(63)$ \\
\hline Agoseris glauca & $(50)$ & 2 & (49) & 2 & $(100)$ & 2 & $(100)$ & & $(33)$ & 1 & $(100)$ & 5 & $(86)$ & 2 & (50) \\
\hline A. granditlora & - - & & - - & & (7) & $\mathrm{p}$ & & & - & & $(22)$ & 1 & $(43)$ & $\mathrm{p}$ & $(13)$ \\
\hline 12 izm cemum & $(60)$ & $\mathrm{p}$ & $(75)$ & 1 & $(67)$ & $\mathrm{p}$ & $(25)$ & $\mathrm{p}$ & (3.5) & 1 & - - & & -- & & -- \\
\hline naphalis maraaritacea & - & & -- & & (27) & $\mathrm{p}$ & $(25)$ & 1 & -- & & (11) & $\mathrm{p}$ & (71) & $\mathrm{p}$ & (13) \\
\hline norosace septentmionalis & - - & & (7) & $\mathrm{p}$ & - - & & -- & & -- & & $(22)$ & $\mathrm{p}$ & $(57)$ & $\mathrm{p}$ & (25) \\
\hline nemone patens & -- & & $(4)$ & $\mathrm{p}$ & $(20)$ & $\mathrm{p}$ & $(50)$ & $\mathrm{p}$ & $(33)$ & $\mathrm{p}$ & -- & & (14) & $\mathrm{p}$ & -- \\
\hline Antennaria rosea & $(60)$ & 1 & $(80)$ & 2 & $(80)$ & 3 & (100) & 7 & $(100)$ & $\mathrm{p}$ & $(78)$ & 1 & (71) & $\mathrm{p}$ & (38) \\
\hline rabis dmumonditi & (10) & $\mathrm{p}$ & -- & & (13) & $\mathrm{p}$ & $(50)$ & $\mathrm{p}$ & - & & -- & & -- & & $(25)$ \\
\hline Arenaria congesta & $(50)$ & 1 & (63) & 1 & $(95)$ & 5 & $(100)$ & 4 & (33) & 1 & $(89)$ & 2 & $(100)$ & 1 & $(15)$ \\
\hline Amica furgens & $(20)$ & $\mathrm{p}$ & (17) & $\mathrm{p}$ & $(33)$ & 1 & -- & & - & & $(22)$ & $\mathrm{p}$ & -- & & (13) \\
\hline A. soropia & -- & & (2) & $\mathrm{p}$ & - & & - & & -- & & - - & & -- & & -- \\
\hline Intemisia Iudoviciano & $(40)$ & 3 & (26) & 1 & (13) & 1 & -- & & $(33)$ & $\mathrm{p}$ & - - & & -- & & -- \\
\hline Aster alpigenus & -- & & -- & & - - & & -- & & -- & & - - & & -- & & (13) \\
\hline A. campestmis & -- & & (2) & $\mathrm{p}$ & (7) & $\mathrm{p}$ & -- & & $(3 \overline{3})$ & 1 & -- & & (14) & $\mathrm{p}$ & -- \\
\hline A. foliaceus & - - & & -- & & -- & & -- & & -- & & -- & & (14) & 1 & $(38)$ \\
\hline A. integmifolius & - - & & $(2)$ & $\mathrm{p}$ & $(27)$ & 2 & -- & & -- & & $(22)$ & 2 & (29) & $\mathrm{p}$ & - \\
\hline Astragalus miser & - - & & (28) & 1 & $(20)$ & p & (25) & $\mathrm{p}$ & (33) & 4 & $(22)$ & $\mathrm{p}$ & (29) & $\mathrm{p}$ & -- \\
\hline - pursinii & $(40)$ & 1 & $(30)$ & $\mathrm{p}$ & (15) & $\mathrm{p}$ & -- & & -- & & (11) & $\mathrm{p}$ & -- & & -- \\
\hline itsamorhiza ineana & (20) & 1 & (2) & $\mathrm{p}$ & - - & & -- & & -- & & -- & & -- & & -- \\
\hline sagittata & - & & (33) & 1 & -- & & -- & & -- & & -- & & -- & & -- \\
\hline sseya wyomingensis & $(30)$ & 1 & $(24)$ & $\mathrm{p}$ & $(60)$ & 1 & $(75)$ & 2 & $(35)$ & $\mathrm{p}$ & $(44)$ & $\mathrm{p}$ & $(57)$ & $\mathrm{p}$ & $(25)$ \\
\hline
\end{tabular}

(con.) 
APPENDIX E4 (con.)

\begin{tabular}{|c|c|c|c|c|c|c|c|c|}
\hline \multirow[b]{2}{*}{ Species } & \multirow{2}{*}{ 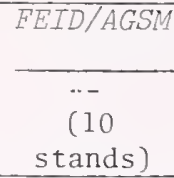 } & \multicolumn{2}{|c|}{ FEID/AGSP } & \multirow{2}{*}{$\begin{array}{c}\text { FEID/CAFI } \\
-- \\
(4 \\
\text { stands) } \\
\end{array}$} & \multirow{2}{*}{$\begin{array}{c}\text { FEID/ } \\
\text { STRIC } \\
-- \\
(3 \\
\text { stands })\end{array}$} & \multicolumn{2}{|c|}{ FETD/AGCA } & \multirow{2}{*}{$\frac{\text { FEID/DEC }}{--}$} \\
\hline & & $\begin{array}{c}-- \\
(45 \\
\text { stands) }\end{array}$ & $\begin{array}{c}\text { STOC } \\
(15 \\
\text { stands) }\end{array}$ & & & $\begin{array}{c}-- \\
(9 \\
\text { stands) }\end{array}$ & $\begin{array}{c}\text { GEVI } \\
(7 \\
\text { stands) }\end{array}$ & \\
\hline
\end{tabular}

Forbs

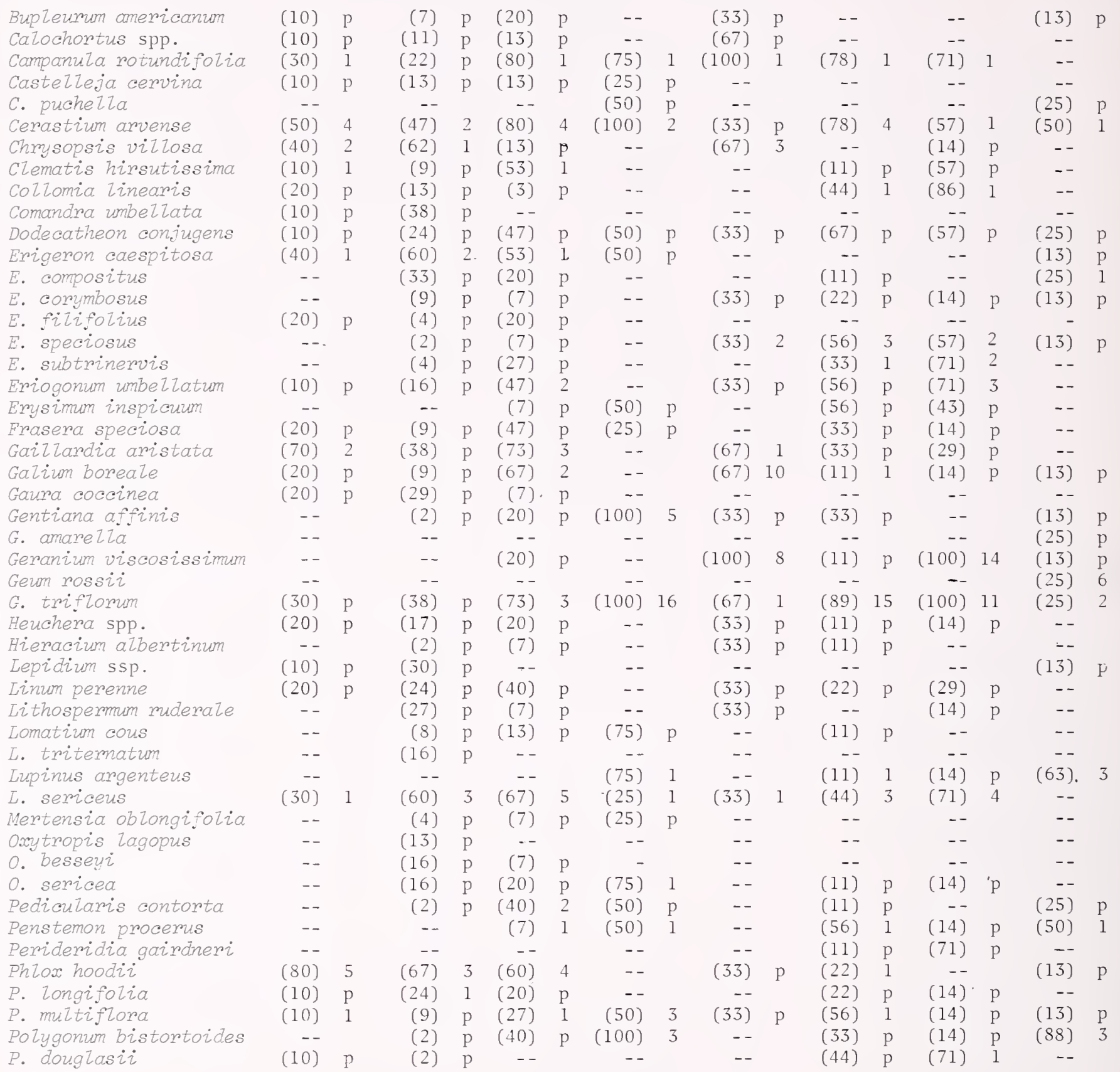


APPENDIX E4 (con.)

\begin{tabular}{|c|c|c|c|c|c|c|c|c|}
\hline \multirow[b]{2}{*}{ Species } & \multirow{2}{*}{$\begin{array}{c}\text { FEID/AGS: } \\
-- \\
(10 \\
\text { stands })\end{array}$} & \multicolumn{2}{|c|}{ FEID/AGSP } & \multirow{2}{*}{$\begin{array}{c}\text { FEID/CAEI } \\
\begin{array}{c}(t \\
\text { stands })\end{array}\end{array}$} & \multirow{2}{*}{$\begin{array}{c}\text { FEID/ } \\
\text { STRI } \\
-- \\
(3 \\
\text { stands })\end{array}$} & \multicolumn{2}{|c|}{ FEID/AGCA } & \multirow{2}{*}{$\begin{array}{c}\text { FEID/DEC } \\
-- \\
\text { stands) }\end{array}$} \\
\hline & & $\begin{array}{c}-- \\
(45 \\
\text { stands) }\end{array}$ & $\begin{array}{c}\text { STOC } \\
(15 \\
\text { stands) }\end{array}$ & & & $\begin{array}{c}-- \\
(9 \\
\text { stands) }\end{array}$ & $\begin{array}{c}\text { CEVII } \\
(7 \\
\text { stands) }\end{array}$ & \\
\hline
\end{tabular}

Forbs (con.)

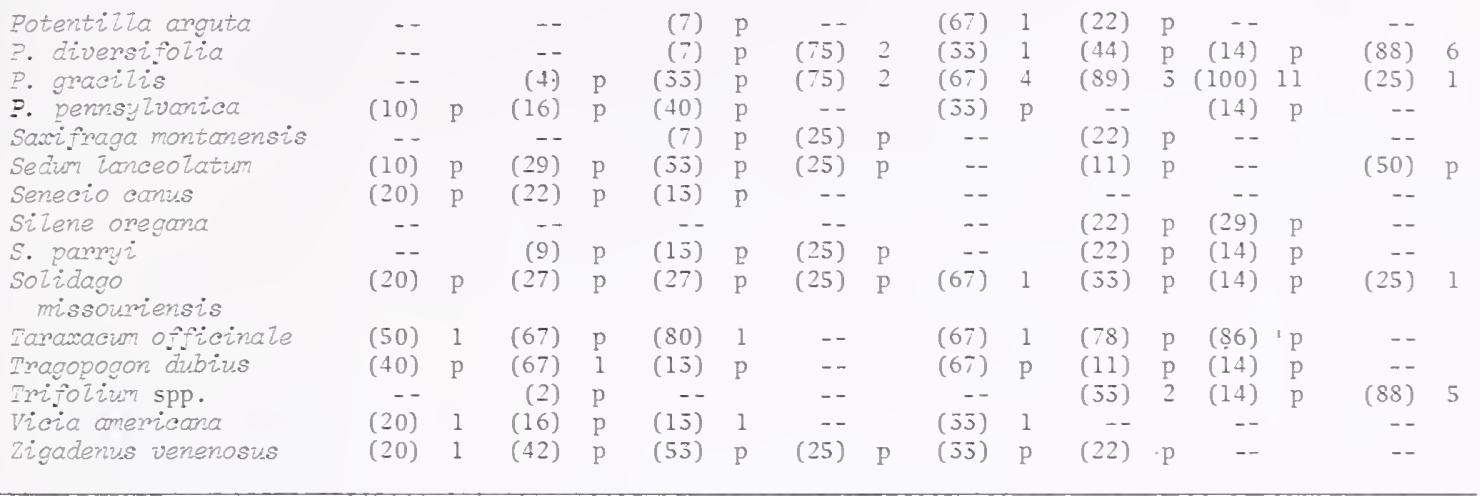

${ }^{\mathrm{l}} \mathrm{p}=$ present with less than 0.5 percent canopy cover. 


\section{E5. - Deschampsia caespitosa Series}

Species constancy (in parentheses) and average canopy cover for important species in the Deschampsia caespitosa/Carex spp. h.t. (DECA/Carex)

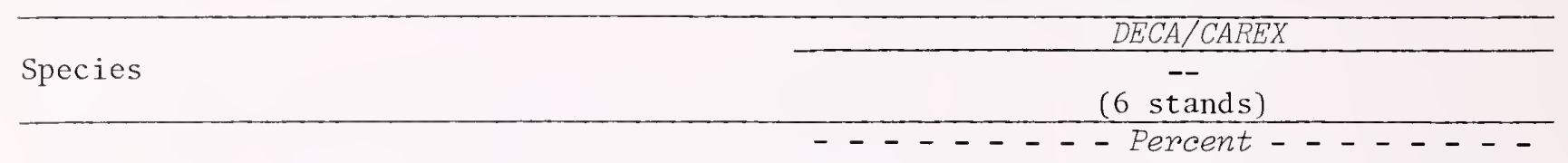

Low Shrubs

Vaccinium scoparium

(17) 1

Graminoids

Agrostis diegoensis

(17) 4

A. humilis

A. idahoensis

A. scabra

Alopecums pratensis

Carex albanigra

C. athrostachya

C. parmana

C. mpestris

C. scopuzomum

Danthonia intermedia

Deschampsia caespitosa

(17) 1

(33) $\mathrm{p}$

(33) 1

(33) 3

(17) $\mathrm{p}^{1}$

(33) 14

(50) 10

(17) 7

(33) 6

(83) 5

Juncus balticus

J. hallii

(100) 45

J. mertensianus

(17) 1

J. parryi

Luzula campestris

Phleum alpinum

Poa pratensis

Trisetum wolfii

(33) 3

(17) 1

(17) 1

(33) $\mathrm{p}$

(83) 2

(33) p

(33) 2

Forbs

Achizlea mizlefolium

Antennaria corymbosa

(17) 1

Amica chamissonis

Aster foliaceus

(67) 6

Camasia quamash

(17) 1

Emigeron speciosus

(17) 2

Gentiana affinis

(17) 3

Pedicularis gronentandica

(50) 5

Polygonum bistortoides

(33) p

Potentizia arguta

(33) $\mathrm{p}$

(83) 1

P. diversifolia

P. gracizis

Rumex paucifolius

(17) $\mathrm{p}$

(33) $\mathrm{p}$

(83) 1

R. salicifolius

(17) $\mathrm{p}$

(17) 1

senecio intergerrimus

(17) 3

S. Zugens

S. wernerifolius

(33) $\mathrm{p}$

Trifolium spp.

Veronica wormskjoldii

3

(33) p

(33) 1

${ }^{1} \mathrm{p}=$ present with less than 0.5 percent canopy cover. 


\section{E6. - Artemisia arbuscula Series}

Species constancy (in parentheses) and average canopy cover for important habitat types within the Artemisia arbuscula series: Artemisia arbuscula/Agropyron spicatum h.t. (ARAR/AGSP), with Stipa comata phase (STCO); and A. arbuscula/Eestuca idahoensis h.t. $(A R A R / E E I D)$

\begin{tabular}{|c|c|c|c|}
\hline \multirow[b]{2}{*}{ Species } & \multicolumn{2}{|c|}{$A R A R / A G S P$} & ARAR/FEID \\
\hline & $\begin{array}{c}\text { STCO } \\
(5 \text { stands) }\end{array}$ & $(3$ stands $)$ & $(2$ stands $)$ \\
\hline
\end{tabular}

Medium Shrubs

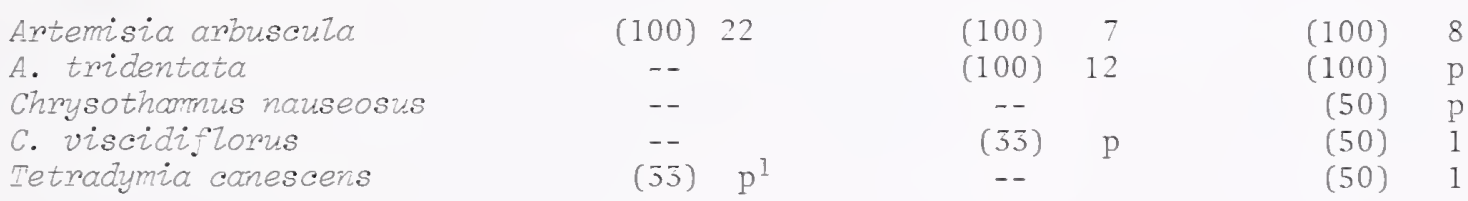

Low Shrubs

\begin{abstract}
Artemisia frigida
Eurotia Zanata

Gutierrezia sarothrae

Leptodactyton pungens

opuntia polyacantha
\end{abstract}

Graminoids

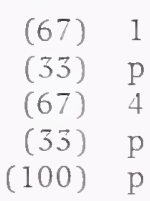
(100) 14
(33) p
(67) p
(53) $\mathrm{p}$
(33) $\mathrm{p}$
--
$(100)$
(67) 1
(100) 1
(100) 3

Stipa comata

S. occidentalis

Forbs
${ }^{1} \mathrm{p}=$ present with less than 0.5 percent canopy cover.

\begin{tabular}{|c|c|c|c|c|c|}
\hline Achizlea mizlefolium & -- & & $(33)$ & $\mathrm{p}$ & $(50)$ \\
\hline Agosemis glauca & -- & & -- & & $(50)$ \\
\hline Alzium cemuum & $(67)$ & $\mathrm{p}$ & $(67)$ & $\mathrm{p}$ & $(100)$ \\
\hline Anaphalis margaritacea & -- & & -- & & $(50)$ \\
\hline Androsace septentmionalis & -- & & -- & & $(50)$ \\
\hline Antennaria rosea & -- & & $(33)$ & $\mathrm{p}$ & $(100)$ \\
\hline Arabis holboelzii & $(33)$ & $\mathrm{p}$ & -- & & $(50)$ \\
\hline A. microphyzza & - & & $(67)$ & $\mathrm{p}$ & -- \\
\hline Arenaria congesta & -- & & $(67)$ & $\mathrm{p}$ & $(50)$ \\
\hline Aster scopulomm & -- & & -- & & $(50)$ \\
\hline Astragalus dmumondii & $(33)$ & $\mathrm{p}$ & -- & & -- \\
\hline A. playtropis & (33) & $\mathrm{p}$ & -- & & -- \\
\hline A. purshizi & $(67)$ & $\mathrm{p}$ & $(67)$ & $\mathrm{p}$ & -- \\
\hline Besseya wyomingensis & -- & & -- & & $(50)$ \\
\hline Bupleumum americanum & -- & & -- & & $(50)$ \\
\hline
\end{tabular}

$\begin{array}{cccc}(100) & 25 & (100) & 24 \\ -- & & -- & \\ -- & & -- & \\ (33) & p & -- & \\ (55) & 1 & -- & \\ -- & & (100) & p \\ -- & & (100) & 31 \\ (53) & 10 & -- & \\ (100) & 8 & (100) & 9 \\ -- & & -- & \\ -- & & (50) & 2 \\ (100) & 2 & (50) & 3 \\ -- & & (50) & p \\ -- & & (50) & p\end{array}$


APPENDIX E6 (cont.)

\begin{tabular}{|c|c|c|c|}
\hline \multirow[b]{2}{*}{ Species } & \multicolumn{2}{|c|}{ ARAR/AGSP } & ARAR/FEID \\
\hline & $\begin{array}{l}\text { STCO } \\
(3 \text { stands })\end{array}$ & $\left(3^{--}\right.$stands) & $\left(\begin{array}{l}-- \\
(2 \text { stands })\end{array}\right.$ \\
\hline
\end{tabular}

Forbs

Castilleja angustifolia

C. cervina

C. Iinariaefolia

C. palzescens

Clematis hirsutissima

Comandra umbellata

Crepis occidentalis

Cryptantha celosioides

Delphinium occidentale

Descurainia michardsonii

Dodecatheon conjugens

Draba oligosperma

Emigeron caespitosa

$E$. compositus

E. corymbosus

$E$. divergens

E. filifolius

E. ochroleucus

E. tweedyi

Eriogonum microthecum

E. ovalifolium

E. umbelzatum

Frasera speciosa

Geum triflorum

Haplopappus acaulis

Hymenoxys acaulis

Lesquerella alpina

Lewisia rediviva

Liatris punctata

Iinum perenne

Lithospermum incisum

L. ruderale

Oxytropis sericea

Paronychia sessiliflora

Pedicularis contorta

Penstemon aridus

Phlox albomarginata

$P$. hoodii

P. Zongifolia

Potentizla gracizis

$P$. pennsyzvanica

Sedum Zanceolatum

Senecio canus

S. pauperculus

Sphaeralcea coccinea

Taraxacum officinale

Townsendia mensana

T. parryi

Tragopogon dubius

\begin{tabular}{|c|c|c|c|c|}
\hline-- & & $(67)$ & 2 & -- \\
\hline-- & & -- & & (50) \\
\hline-- & & (33) & $\mathrm{p}$ & - \\
\hline -- & & (33) & $\mathrm{p}$ & -- \\
\hline-- & & - & & (50) \\
\hline (67) & $\mathrm{p}$ & (33) & $\mathrm{p}$ & (50) \\
\hline- & & (67) & 1 & (50) \\
\hline (33) & $\mathrm{p}$ & -- & & (50) \\
\hline- & & -- & & (50) \\
\hline (33) & $\mathrm{p}$ & -- & & -- \\
\hline- & & -- & & (50) \\
\hline (33) & $\mathrm{p}$ & -- & & -- \\
\hline-- & & (67) & $\mathrm{p}$ & -- \\
\hline-- & & -- & & $(100)$ \\
\hline-- & & (37) & $\mathrm{p}$ & -- \\
\hline -- & & (33) & $\mathrm{p}$ & -- \\
\hline (33) & $\mathrm{p}$ & -- & & -- \\
\hline -- & & (67) & $\mathrm{p}$ & -- \\
\hline (33) & $\mathrm{p}$ & -- & & (50) \\
\hline (33) & $\mathrm{p}$ & -- & & -- \\
\hline (33) & $\mathrm{p}$ & (33) & $\mathrm{p}$ & -- \\
\hline (33) & $\mathrm{p}$ & -- & & -- \\
\hline-- & & -- & & (50) \\
\hline -- & & -- & & (50) \\
\hline (33) & $\mathrm{p}$ & (67) & $\mathrm{p}$ & - \\
\hline (33) & $\mathrm{p}$ & (67) & $\mathrm{p}$ & -- \\
\hline (67) & $\mathrm{p}$ & (33) & $\mathrm{p}$ & $(50)$ \\
\hline-- & & (33) & $\mathrm{p}$ & -- \\
\hline (33) & $\mathrm{p}$ & -- & & -- \\
\hline$(67)$ & $\mathrm{p}$ & $(100)$ & 1 & $(100)$ \\
\hline-- & & - & & $(50)$ \\
\hline (33) & $\mathrm{p}$ & -- & & - \\
\hline -- & & -- & & (50) \\
\hline (33) & 1 & -- & & -- \\
\hline -- & & -- & & (50) \\
\hline -- & & (33) & $\mathrm{p}$ & -- \\
\hline (33) & $\mathrm{p}$ & -- & & -- \\
\hline$(67)$ & $\mathrm{p}$ & $(100)$ & 9 & $(100)$ \\
\hline- & & -- & & $(50)$ \\
\hline-- & & -- & & (50) \\
\hline -- & & (33) & $\mathrm{p}$ & -- \\
\hline (33) & $\mathrm{p}$ & (33) & $\mathrm{p}$ & (50) \\
\hline (67) & $\mathrm{p}$ & (33) & $\mathrm{p}$ & (50) \\
\hline- & & -- & & (50) \\
\hline (33) & $\mathrm{p}$ & -- & & -- \\
\hline-- & & (33) & $\mathrm{p}$ & $(100)$ \\
\hline-- & & -- & & $(50)$ \\
\hline-- & & -- & & $(50)$ \\
\hline (33) & $\mathrm{p}$ & -- & & -- \\
\hline
\end{tabular}




\section{E7. - Artemisia tridentata Series}

Species constancy (in parentheses) and average canopy cover for important species in the following habitat types within the Artemisia tridentata series: Artemisia tridentatal Agropyron spicatum (NONT.) h.t. (ARTR/AGSP); A. tridentata/Festuca scabrella h.t. (ARTR/EESC); and A. tmidentata/Festuca idahoensis (MONT.) h.t. (ARTR/EEID), with Geranium viscosissimum phase (GEVI)

\begin{tabular}{|c|c|c|c|}
\hline & $A R T R / A G S P$ & ARTR/EESC & $A R T R / E E I D$ \\
\hline Species & $(6$ stands) & $(6$ stands $)$ & $(8$ stands $) \quad(4$ stands $)$ \\
\hline
\end{tabular}

Medium Shrubs

Amelanchier alnifolia

Artemisia tridentata

Chrysothamus nauseosus

C. viscidifloms

Rosa arkansana

Tetradymia canescens

Low Shrubs

Arctostophylos uva-ursi

Artemisia frigida

Gutierrezia sarothrae

opuntia polyacantha

Graminoids

Agropyron canium

A. dasystachyum

A. smithii

A. spicatum

Bouteloua gracizis

Bromus caminatus

B. ciliatus

Calamagrostis mbescens

Carex obtusata

C. petasata

C. pennsyzvanica

C. raynoldsii

C. stenophyzla

Danthonia intermedia

Festuca idahoensis

F. scabrelza

Koelemia cmistata

Poa cusickii

P. juncifolia

P. sandbergii

Stipa comata

S. occidentalis

S. michardsonii

Forbs

Achillea milzefolium

Agosemis glauca

Altium cermuum

Anaphalis marganitacea

Androsace occidentalis

$\begin{array}{rrrr}-- & & (50) & \mathrm{p} \\ (100) & 15 & (100) & 21 \\ (33) & \mathrm{p}^{1} & (17) & \mathrm{p} \\ (17) & \mathrm{p} & -- & \\ -- & & (50) & \mathrm{p} \\ (17) & \mathrm{p} & (17) & \mathrm{p}\end{array}$

(100) 18

(25) $\mathrm{p}$

(75) 1

(25) p

$\begin{array}{rrrr}-- & & (17) & 1 \\ (83) & 2 & (33) & p \\ (83) & 2 & -- & \\ (67) & p & -- & \end{array}$

(63) 1

(13) p

(13) $\mathrm{p}$

$--$

$-$

\begin{tabular}{|c|c|c|c|c|c|c|c|}
\hline-- & & -- & & -- & & $(100)$ & 12 \\
\hline-- & & -- & & (13) & 2 & - & \\
\hline -- & & (17) & 1 & (13) & $\mathrm{p}$ & -- & \\
\hline$(100)$ & 32 & (83) & 6 & (75) & 5 & $(100)$ & \\
\hline$(83)$ & 1 & $(33)$ & $\mathrm{p}$ & -- & & -- & \\
\hline -- & & -- & & -- & & $(75)$ & 13 \\
\hline-- & & -- & & (13) & 1 & - & \\
\hline-- & & -- & & -- & & $(50)$ & \\
\hline -- & & -- & & (25) & 2 & -- & \\
\hline (17) & $\mathrm{p}$ & (17) & 1 & (25) & 1 & (25) & \\
\hline- & & - & & (25) & 1 & - & \\
\hline-- & & - & & -- & & $(75)$ & \\
\hline (50) & 1 & $(17)$ & $\mathrm{p}$ & -- & & (25) & \\
\hline-- & & (33) & 2 & (38) & $\mathrm{p}$ & $(100)$ & 16 \\
\hline-- & & (83) & 16 & $(100)$ & 39 & $(100)$ & 3 \\
\hline -- & & $(100)$ & 25 & - & & - & \\
\hline (83) & 5 & $(100)$ & 1 & (88) & 4 & $(100)$ & \\
\hline- & & (83) & $\mathrm{p}$ & (25) & $\mathrm{p}$ & - & \\
\hline -- & & (17) & $\mathrm{p}$ & -- & & $(100)$ & \\
\hline (83) & 2 & (17) & $\mathrm{p}$ & (88) & 1 & - & \\
\hline (83) & 2 & $=$ & & (38) & 1 & (25) & \\
\hline -- & & -- & & (38) & $\mathrm{p}$ & $(100)$ & 14 \\
\hline-- & & $(17)$ & 3 & (25) & $\mathrm{p}$ & (25) & \\
\hline
\end{tabular}

\begin{tabular}{|c|c|c|c|c|c|c|}
\hline (17) & $p$ & $(100)$ & 1 & $(75)$ & 1 & $(100)$ \\
\hline -- & & (17) & $\mathrm{p}$ & (63) & 1 & $(100)$ \\
\hline (67) & $\mathrm{p}$ & $(83)$ & p & (63) & 1 & -- \\
\hline 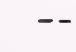 & & (17) & $\mathrm{p}$ & -- & & (50) \\
\hline-- & & -- & & -- & & $(50)$ \\
\hline
\end{tabular}


APPENDIX E7 (con.)

\begin{tabular}{|c|c|c|c|c|}
\hline \multirow[b]{2}{*}{ Species } & $A R T R / A G S P$ & ARTR/FESC & $A R I$ & FEID \\
\hline & $(6$ stands) & $(6$ stands) & $(8$ stands $)$ & $\begin{array}{c}\text { GEVI } \\
(4 \text { stands })\end{array}$ \\
\hline
\end{tabular}

Forbs (con.)

\begin{tabular}{|c|c|c|c|c|c|c|c|}
\hline Androsace septentrionalis & -- & & -- & & $(25)$ & $\mathrm{p}$ & $(25)$ \\
\hline Anemone patens & -- & & -- & & -- & & $(50)$ \\
\hline Antennaria parvifolia & $(17)$ & $\mathrm{p}$ & $(17)$ & $\mathrm{p}$ & $(13)$ & 2 & (75) \\
\hline A. rosea & (33) & $\mathrm{p}$ & $(83)$ & 4 & $(75)$ & 4 & (25) \\
\hline Arabidopsis thatiana & -- & & -- & & $(25)$ & $\mathrm{p}$ & $(75)$ \\
\hline Arabis holboelzii & $(33)$ & $\mathrm{p}$ & $(33)$ & $\mathrm{p}$ & (13) & $\mathrm{p}$ & -- \\
\hline Arenaria congesta & $(17)$ & $\mathrm{p}$ & (83) & 2 & $(50)$ & $\mathrm{p}$ & $(100)$ \\
\hline Artemisia Iudoviciana & -- & & $(50)$ & 1 & (13) & $\mathrm{p}$ & -- \\
\hline Aster campestris & -- & & -- & & -- & & $(75)$ \\
\hline A. falcatus & -- & & $(50)$ & $\mathrm{p}$ & -- & & - \\
\hline Astragalus drummondii & $(17)$ & $\mathrm{p}$ & $(17)$ & $\mathrm{p}$ & $(25)$ & 1 & -- \\
\hline A. miser & -- & & (17) & 2 & $(25)$ & 1 & $(75)$ \\
\hline A. purshii & (33) & $\mathrm{p}$ & (33) & $\mathrm{p}$ & (13) & $\mathrm{p}$ & - \\
\hline Balsamorhiza sagittata & -- & & (33) & $\mathrm{p}$ & (13) & $\mathrm{p}$ & $(50)$ \\
\hline Besseya wyomingensis & -- & & -- & & $(50)$ & $\mathrm{p}$ & - \\
\hline Campanuza rotundifolia & -- & & $(50)$ & $\mathrm{p}$ & (13) & $\mathrm{p}$ & $(100)$ \\
\hline Cerastium arvense & -- & & (67) & 1 & $(25)$ & 1 & $(50)$ \\
\hline Chrysopsis vizzosa & $(17)$ & $\mathrm{p}$ & (17) & $\mathrm{p}$ & $(50)$ & 1 & -- \\
\hline Clematis hirsutissima & - & & (33) & $\mathrm{p}$ & (13) & 1 & $(25)$ \\
\hline Cozzomia Zinearis & -- & & (17) & $\mathrm{p}$ & -- & & $(100)$ \\
\hline Comandra umbelzata & $(17)$ & $\mathrm{p}$ & $(50)$ & $\mathrm{p}$ & $(50)$ & $\mathrm{p}$ & -- \\
\hline Crepis occidentalis & $(50)$ & $\mathrm{p}$ & (33) & $\mathrm{p}$ & (13) & $\mathrm{p}$ & -- \\
\hline Cymoptems bipinnatus & -- & & - & & (25) & 1 & -- \\
\hline Delphinium bicolor & -- & & -- & & (25) & $\mathrm{p}$ & -- \\
\hline Dodecatheon conjugens & -- & & -- & & $(38)$ & $\mathrm{p}$ & $(100)$ \\
\hline Emigeron caespitosus & $(50)$ & $\mathrm{p}$ & (33) & 1 & (13) & $\mathrm{p}$ & -- \\
\hline E. compositus & $(50)$ & $\mathrm{p}$ & (33) & $\mathrm{p}$ & $(50)$ & 1 & -- \\
\hline E. filifolius & $(33)$ & $\mathrm{p}$ & (17) & $\mathrm{p}$ & -- & & -- \\
\hline Erigonum umbellatum & $(17)$ & $\mathrm{p}$ & $(67)$ & 1 & $(38)$ & $\mathrm{p}$ & $(100)$ \\
\hline Erysimum asperum & -- & & - & & - - & & $(75)$ \\
\hline Fragaria virginiana & -- & & $(33)$ & $\mathrm{p}$ & -- & & $(25)$ \\
\hline Geranium viscosissimum & -- & & (33) & $\mathrm{p}$ & -- & & $(100)$ \\
\hline Geum triflomu & $(17)$ & $\mathrm{p}$ & (17) & 1 & $(75)$ & 2 & $(100)$ \\
\hline Haplopappus acaulis & $(17)$ & $\mathrm{p}$ & -- & & $(38)$ & 1 & - \\
\hline Helianthella uniflora & -- & & -- & & -- & & $(100)$ \\
\hline Heuchera cyzindrica & -- & & -- & & $(25)$ & $\mathrm{p}$ & -- \\
\hline Lesquerelia alpina & -- & & $(50)$ & $\mathrm{p}$ & (13) & $\mathrm{p}$ & -- \\
\hline Iinum perenne & $(17)$ & $\mathrm{p}$ & $(50)$ & $\mathrm{p}$ & $(13)$ & $\mathrm{p}$ & $(75)$ \\
\hline Iithospermum muderale & $(33)$ & $\mathrm{p}$ & (33) & $\mathrm{p}$ & $(25)$ & $\mathrm{p}$ & - \\
\hline Lomatium tritematum & $(17)$ & $\mathrm{p}$ & $(17)$ & $\mathrm{p}$ & -- & & $(75)$ \\
\hline Lupinus sericeus & $(33)$ & 1 & $(50)$ & 2 & $(50)$ & 3 & (25) \\
\hline I. wyethia & -- & & -- & & -- & & $(75)$ \\
\hline Mertensia obligifolia & -- & & -- & & $(25)$ & $\mathrm{p}$ & -- \\
\hline Oxytropis besseyi & $(33)$ & 1 & -- & & -- & & -- \\
\hline o. sericea & $(33)$ & $\mathrm{p}$ & -- & & (13) & $\mathrm{p}$ & -- \\
\hline Phlox hoodii & (33) & 1 & $(67)$ & $\mathrm{p}$ & $(50)$ & 2 & -- \\
\hline P. Zongifolia & - - & & (17) & $\mathrm{p}$ & (13) & $\mathrm{p}$ & $(50)$ \\
\hline P. multiflora & -- & & -- & & $(50)$ & $\mathrm{p}$ & $(25)$ \\
\hline Polygonum douglasii & -- & & -- & & - - & & (75) \\
\hline
\end{tabular}

(con.) 
APPENDIX E7 (con.)

\begin{tabular}{|c|c|c|c|}
\hline & $A R T R / A G S P$ & ARTR/FESC & ARTR/FEID \\
\hline Species & $(6$ stands) & $(6$ stands) & $\begin{array}{ll}\text { GEVI } \\
\text { is }) \quad(4 \text { stands })\end{array}$ \\
\hline
\end{tabular}

Forbs (con.)

$\begin{array}{lrrrr}\text { Potentilia arguta } & -- & (17) & \mathrm{p} \\ P . \text { glandulosa } & -- & -- & \\ \text { P. gracilis } & -- & & (50) & 1 \\ \text { P. pennsylvanica } & (17) & \mathrm{p} & (33) & \mathrm{p} \\ \text { Sedum Ianceolatum } & -- & & -- & \\ \text { Senecio canus } & (33) & \mathrm{p} & (33) & \mathrm{p} \\ \text { Silene parryii } & -- & & -- & \\ \text { Taraxacum officinale } & (17) & \mathrm{p} & (67) & \mathrm{p} \\ \text { Tragopogon dubius } & (50) & \mathrm{p} & (67) & \mathrm{p} \\ \text { Vicia americana } & -- & & (33) & \mathrm{p} \\ \text { Zigadenus venenosus } & -- & -- & \end{array}$

${ }^{1} p=$ present with less than 0.5 percent canopy cover. 


\section{E8. - Artemisia tripartita Series}

Species constancy (in parentheses) and average canopy cover for important species in the Artemisia tripartita/Festuca idahoensis h.t. (MONT.) (ARTRI/FEID)

\begin{tabular}{ll}
\hline Species & ARTRI/FEID \\
\cline { 2 - 2 } & $(5$ stands $)$ \\
\hline
\end{tabular}

Medium Shrubs

Artemisia tridentata

(60) 1

A. tripartita

(100) 12

Chrysothamns viscidifloms

(100) 4

Tetradymia canescens

(80) 3

Low Shrubs

Artemisia frigida

Gutierrezia sarothrae

(80) 1

(40) $\mathrm{p}^{1}$

Graminoids

Agropyron caninum

A. dasystachyum

A. spicatum

Calamagrostis montanensis

Carex stenophyzla

Festuca idahoensis

Koeleria cristata

Poa cusickii

$P$. sandbergii

Stipa comata

(60) 7

(60) 7

(20) 7

(100) 8

(80) 1

(100) 56

(100) 5

(60) 5

(40) 1

(20) 10

Forbs

Achillea millefolium

(100) p

Agoseris glauca

Androsace septentrionalis

(40) p

Antennaria rosea

Arabidopsis thaliana

Comandra umbellata

(40) p

(60) 2

(40) p

Erigeron compositus

(40) 1

Eriogonum umberlatum

(60) p

(60) p

Geum triflomm

(40) p

Lepidium spp.

Lupinus sericeus

(40) p

(60) 13

Phlox hoodii

(100) 5

Sedum Zanceolatum

(40) p

Taraxacum officinale

(80) 1

Tragopogon dubius

(40) p

${ }^{1} \mathrm{p}=$ present with less than 0.5 percent canopy cover. 


\section{E9. - Potentilla fruticosa Series}

Species constancy (in parentheses) and average canopy cover for important species in the following habitat types within the Potentizla fruticosa series: Potentilla fruticosal Festuca scabrella h.t. (POFR/FESC), with Danthonia intermedia phase (DAIN); and in the P. fruticosa/Festuca idahoensis h.t. (POFR/FEID)

\begin{tabular}{|c|c|c|c|}
\hline \multirow[b]{2}{*}{ Species } & \multicolumn{2}{|c|}{ POER/EESC } & POFR/FEID \\
\hline & $(5$ stands) & $\begin{array}{l}\text { DAIN } \\
(6 \text { stands) } \\
\end{array}$ & (4 stands) \\
\hline
\end{tabular}

Medium Shrubs

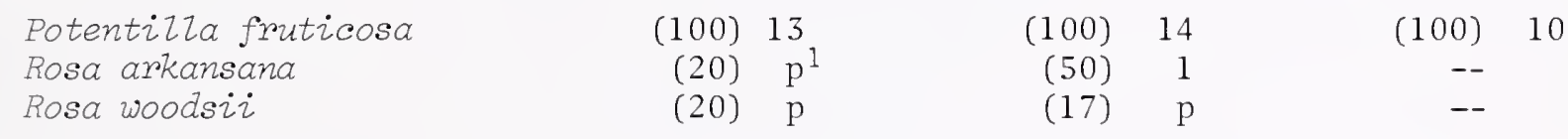

Low Shrubs

Arctostaphylos uva-ursi

Artemisia frigida

A. campestivis

Gutierrezia sarothrae

Juniperus horizontalis

Graminoids

Agropyron canium

A. dasystachyum

A. smithii

A. spicatum

Agrostis scabra

Bouteloua gracilis

Bromus carinatus

B. ciziatus

Calamagrostis purpurascens

Calamovilfa longifolia

Carex filifolia

C. hoodii

C. obtusata

C. parmana

C. pennsyrvanica

C. petasata

C. practicola

C. raynoldsii

C. scimpoidea

C. stenophyzla

C. vallicola

Danthonia intermedia

D. parryi

Festuca idahoensis

F. scabrezza

Helictotmichon hookeri

Koeleria cristata

Luzula spicata

Muhlenbergia cuspidata

M. Nichardsonii

Phleum pratense

Poa grayana

P. interior

$P$. juncifolia
(20) 1

(100) 2

(60) 1

(80) p

(20) p

(20) p

(20) 1

(20) 1

(80) 9

(40) 1

--

--

(40) p

(40) 1

(40) p

(20) p

$--$

--

(80) 5

(20) p

--

(40) 13

(80) 5

(100) 17

(60) p

(100) 4

(60) p

(80) 1

(60) $\mathrm{p}$

$--$

$--$
(67)

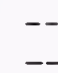

(33)

(100) 2

(33)

(17)

(33)

(33)

(17)

(17)

(17)

(17)

(67)

(33)

(67)

--

(17)

(17)

(17)

(100)

(100) 16

(100) 48

(83) p

(100) 1

$-$

$-$

--

$-$

(17)
11

--
--
--
--
(50) 2

(25) $\mathrm{p}$

(50) 1

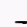

--

(75) 1

(25) 4

--
$(75) \quad 8$

(25) 3

(25)

(25)

25) 1

(25) 4

(75) 18

--

(100) 40

(25) $p$

(50) p

(75) 1

(50) 1

--

$-$

(25)

(25)

(25)

(con.) 


\begin{tabular}{|c|c|c|c|}
\hline \multirow[b]{2}{*}{ Species } & \multicolumn{2}{|c|}{ POFR/FESC } & $\overline{P O F R / F E I D}$ \\
\hline & $\begin{array}{ll} & -- \\
(5 & \text { stands })\end{array}$ & $\begin{array}{c}D A I N \\
(6 \text { stands) }\end{array}$ & $\left(\begin{array}{ll}-- & \text { stands }\end{array}\right.$ \\
\hline
\end{tabular}

Graminoids (con.)

Poa nevadensis

$P$. pratensis

P. mpicola

P. sandbergii

Stipa occidentalis

S. richardsonii

S. vimidula

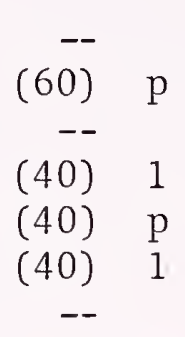

(83)

(17)

(33)

(33)
(25) 1

(25) $\mathrm{p}$

(25)

$\begin{array}{ll}\text { (25) } & \mathrm{p} \\ \text { (25) } & 2\end{array}$

Forbs

Achizlea mizleforium

Agoseris gtauca

Altium cemuum

Anaphalis margamitacea

Anemone multifida

A. patens

Antennaria anaphaloides

A. parvifolia

A. rosea

Arabis holboelzii

Arenaria congesta

Amica fulgens

A. soromia

Artemisia Zudoviciana

Aster intergrifolius

Astragalus miser

A. purshii

Besseya wyomingensis

Bup leurum americanum

Campanula rotundifolia

Cerastium amense

Chrysopsis vilzosa

Clematis hirsutissima

Comandra umbelzata

Cryptantha celosioides

Dodecatheon conjugens

Douglasia montana

Erigeron caespitosus

E. compositus

E. corymbosus

E. filifolia

E. simplex

E. speciosus

Eriogonum umberlatum

Eragaria virginiana

Erasera speciosa

Gailzardia aristata

Galium boreale

Gentiana affinis

Geranium viscosissumum

$\begin{array}{rr}(100) & 1 \\ (60) & \mathrm{p} \\ (100) & 1 \\ -- & \\ (20) & \mathrm{p} \\ (60) & \mathrm{p} \\ -- & \\ (80) & 2 \\ (20) & \mathrm{p} \\ (40) & \mathrm{p} \\ (40) & \mathrm{p} \\ -- & \\ -- & \\ -- & \\ (60) & \mathrm{p} \\ -- & \\ (40) & \mathrm{p} \\ (20) & \mathrm{p} \\ (20) & \mathrm{p} \\ (80) & 1 \\ (60) & 1 \\ (80) & 1 \\ -- & \\ (60) & \mathrm{p} \\ (20) & \mathrm{p} \\ (20) & \mathrm{p} \\ -- & \\ (60) & 1 \\ (40) & \mathrm{p} \\ (20) & \mathrm{p} \\ (20) & \mathrm{p} \\ -- & \\ -- & \\ (20) & \mathrm{p} \\ (20) & \mathrm{p} \\ (40) & \mathrm{p} \\ (100) & 2 \\ (100) & 3 \\ (20) & \mathrm{p} \\ - & \end{array}$

(100) 2

(100) 3

(67) p

(33) p

(33) $\mathrm{p}$

(67)

(33)

(17)

(50)

(67)

(17)

(33)

(33)

(33)

(17)

(67)

(67)

(100)

(100)

(33)

(33)

(17)

$(100) \quad p$
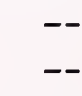

(17)

p

(50) 3

(17)

(83)

(17)

(83)

(100)

(50)
(100) 5

(75) 3

(50) 1

(25) 1

(25) p

(25) 1

(25) $\mathrm{p}$

(75) 1

(100) 3

(25) $\mathrm{p}$

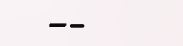

(25) $\mathrm{p}$

(100) 4

(25) $\mathrm{p}$

(100) 2

(75) 4

(25) $\mathrm{p}$

(25) p

(75) $\mathrm{p}$

(50) p

(50) p

(25) 1

(25) $\mathrm{p}$

(25) $\mathrm{p}$

(75) 1

(25) $\mathrm{p}$

(50) 2

(25) 2

(con.) 
Appendix E9 (con.)

\begin{tabular}{lccc}
\hline \multirow{2}{*}{ Species } & \multicolumn{2}{c}{ POFR/FESC } & POFR/FEID \\
\cline { 2 - 4 } & -- & DAIN & -- \\
& $(5$ stands $)$ & $(6$ stands $)$ & $(4$ stands $)$ \\
\hline
\end{tabular}

Forbs (con.)

Geum triflorum

Haplopappus acaulis

Hedysarum spp.

Heuchera spp.

Hymenoxys acaulis

Iris missouriensis

Lesquerella alpina

Liatris punctata

Linum perenne

Lithospermum miderale

Lupinus sericeus

Lupinus spp.

Iychnis dmumondii

Monarda fistulosa

oxytropsis campestris

0 . sericea

o. viscida

Pedicularis contorta

Penstemon eriantherus

P. procemis

Petalostemon purpurpeum

Phlox hoodii

P. Kelseyi

P. muscoides

P. pulvinata

Plantago tweedyi

Polygonum bistortoides

Potentilla gracilis

P. hippiana

Sedum Zanceolatum

Senecio canus

S. megacephalus

Solidago missoumiensis

Taraxacum officinale

Thermopsis rhombifolia

Tragopogon dubius

Trifolium spp.

Vicia americana

Viola adunca

Zigadenus elegans

Z. venenosus

\begin{tabular}{rr}
$(60)$ & $\mathrm{p}$ \\
$(40)$ & $\mathrm{p}$ \\
$(40)$ & $\mathrm{p}$ \\
-- & \\
$(40)$ & $\mathrm{p}$ \\
$(40)$ & $\mathrm{p}$ \\
$(40)$ & $\mathrm{p}$ \\
$(40)$ & $\mathrm{p}$ \\
$(80)$ & 1 \\
-- & \\
$(20)$ & $\mathrm{p}$ \\
-- & \\
-- & \\
-- & \\
-- & \\
$(80)$ & 1 \\
$(20)$ & 1 \\
-- & \\
$(40)$ & 1 \\
-- & \\
$(60)$ & $\mathrm{p}$ \\
$(40)$ & $\mathrm{p}$ \\
$(40)$ & 3 \\
$(40)$ & $\mathrm{p}$ \\
-- & \\
$(40)$ & 1 \\
-- & \\
$(20)$ & $\mathrm{p}$ \\
$(40)$ & $\mathrm{p}$ \\
-- & \\
$(100)$ & 2 \\
$(40)$ & 1 \\
$(100)$ & 1 \\
$(40)$ & $\mathrm{p}$ \\
$(40)$ & $\mathrm{p}$ \\
$(60)$ & $\mathrm{p}$ \\
-- & \\
$(20)$ & $\mathrm{p}$ \\
$(40)$ & 1 \\
-- & \\
$(20)$ & $\mathrm{p}$ \\
& \\
\hline
\end{tabular}

\begin{tabular}{|c|c|c|}
\hline$(50)$ & 2 & (75) \\
\hline-- & & -- \\
\hline (67) & 1 & -- \\
\hline -- & & (75) \\
\hline (33) & & -- \\
\hline $\begin{array}{r}(33) \\
--\end{array}$ & $\mathrm{p}$ & -- \\
\hline -- & & -- \\
\hline (33) & p & -- \\
\hline$(50)$ & $\mathrm{p}$ & $\cdots$ \\
\hline (67) & 7 & (25) \\
\hline (17) & $\mathrm{p}$ & (25) \\
\hline-- & & (25) \\
\hline (50) & 1 & -- \\
\hline (17) & $\mathrm{p}$ & (25) \\
\hline (17) & $\mathrm{p}$ & (25) \\
\hline-- & & -- \\
\hline-- & & (25) \\
\hline (33) & $\mathrm{n}$ & $(50)$ \\
\hline - & & - \\
\hline (33) & 2 & (25) \\
\hline -- & & -- \\
\hline-- & & -- \\
\hline -- & & (25) \\
\hline -- & & -- \\
\hline (33) & p & (75) \\
\hline (83) & 3 & $(100)$ \\
\hline (33) & p & - \\
\hline (17) & $\mathrm{p}$ & $(100)$ \\
\hline (17) & $\mathrm{p}$ & - \\
\hline-- & & (25) \\
\hline (83) & 1 & (25) \\
\hline$(50)$ & 1 & (50) \\
\hline -- & & -- \\
\hline (33) & $\mathrm{p}$ & -- \\
\hline (17) & p & (25) \\
\hline$(50)$ & $\mathrm{p}$ & -- \\
\hline-- & & -- \\
\hline-- & & $(50)$ \\
\hline (33) & p & -- \\
\hline
\end{tabular}

${ }^{1} \mathrm{p}=$ present with less than 0.5 percent canopy cover. 


\section{E10. - Purshia tridentata Series}

Species constancy and average canopy cover for important plants in the following habitat types within the Purshia tridentata series: Purshia tridentata/Agropyron spicatrm (MONT.) h.t. (PUTR/AGSP); P. tridentata/Festuca scabrella h.t. (PUTR/FESC); and P. tridentata/Festuca idahoensis h.t. (MONT.) (PUTR/FEID)

\begin{tabular}{|c|c|c|c|c|}
\hline \multirow[b]{2}{*}{ Species } & \multicolumn{2}{|c|}{ PUTR/AGSP } & PUTR/FESC & PUTR/FEID \\
\hline & $\left(\begin{array}{ll}-- \\
\text { stand }\end{array}\right.$ & $(4 \text { stands })^{2}$ & $(4 \text { stands })^{1}$ & $(1 \text { stand })^{2}$ \\
\hline
\end{tabular}

Medium Shrubs

Chrysothamms nauseosus

C. viscidifloms

Purshia tridentata

Rosa arkansana

Low Shrubs

Artemisia frigida

A. dracunculus

2

$\mathrm{p}^{3}$

+
+
$*$

(25) p

(25) $\mathrm{p}$

(100) 17

(25) 1

(25) p

$\mathrm{p}$

Graminoids

Agropyron spicatum

Amistida Zongiseta

58

Bromus mollis

B. tectomum

Festuca idahoensis

F. octoflora

F. scabrelza

Koeleria cristata

Poa sandbergii

Stipa comata

S. occidentalis

S. vimidula

Forbs

Achillea millefolium

Antennaria rosea

Arabis holboelzii

Arenamia congesta

Amica soromia

Arabidopsis thatina

Balsomorhiza sagittata

Centaurea maculosa

Chaenactis douglasii

Chrysopsis vizzosa

Coltinsia parviflora

Colzomia Zimearis

Comandra umbellata

Crepis spp.

Epizobium minutum

Eriogonum corymbosus

E. subtrinervis

Erigonum microthecum

E. umbellatum
(25) p

(50) p

(75) 8

(100) 19

(75) 1

(100) 7

(100) 2

(100) 5

(25) 1

(25) $\mathrm{p}$

$+$

1

p
(100) 2

(50) p

(25) p

(25) p

(50) p

(50) p

(75) 10

(25) 1

(100) 1

(50) p

(50) p

(75) p

(75) $\mathrm{p}$

(25) 3

(25) p

(25) p

(25) $\mathrm{p}$

(con.) 
APPENDIX E10 (con.)

\begin{tabular}{|c|c|c|c|c|}
\hline \multirow[b]{2}{*}{ Species } & \multicolumn{2}{|c|}{ PUTR/AGSP } & PUTR/FESC & PUTR/FEID \\
\hline & $(1$ stand $)$ & $(4 \text { stands })^{2}$ & $(4 \text { stands })^{I}$ & $\left(\begin{array}{l}-- \\
(1 \text { stand })^{2}\end{array}\right.$ \\
\hline
\end{tabular}

Forbs (con.)

Eieracium albertinum

(50) 1

Lepidium spp.

Lithospermum mderale

Lomatium tritematum

Lupinus serecius

Medicago spp.

Myosotis micrantha

Oxytropis spp.

Penstemon diphyzzus

Phacelia linearis

Phlöx spp.

$P$. Zongifolia

P. hooäii

Physaria geyeri

Ste Zraria spp.

Taraxacum officinale

Tragopogon dubius

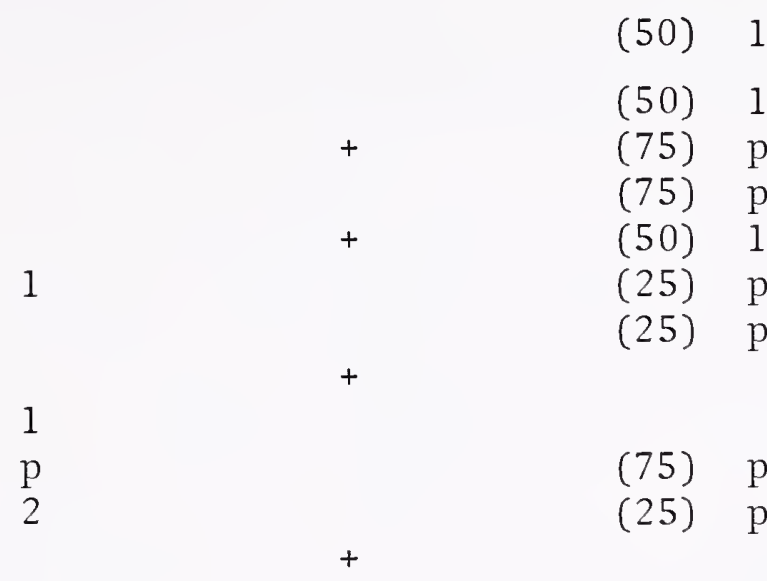

(25) 2

(50) p

(100) 2

${ }^{1}$ Intensive plot data for average canopy cover in the PUTR/AGSP and PUTR/FESC habitat types and for species constancy (in parentheses) in the PUTR/FESC h.t.

${ }^{2}$ General reconnaissance data for average canopy cover. in the PUTR/AGSP and PUTR/FEID habitat types $(+=<1 \% ; *=1-10 \% ; * *=10-20 \% ; * * *=>20 \%)$.

${ }^{3} \mathrm{p}=$ present with less than 0.5 percent canopy cover. 


\section{E11. - Cercocarpus ledifolius Series}

Species constancy and average canopy cover for important p1ants within the Cercocarpus Zedifolius/Agropyron spicatum h.t. (CELE/AGSP)

\begin{tabular}{|c|c|c|}
\hline \multirow{2}{*}{ Species } & \multicolumn{2}{|c|}{ CELE/AGSP } \\
\hline & (1 stand $) 1$ & $(2$ stands $) 2$ \\
\hline & $-\cdots$ & $-\cdots-\cdots$ \\
\hline \multicolumn{3}{|l|}{ Medium and Tall Shrubs } \\
\hline $\begin{array}{l}\text { Artemisia arbuscula } \\
\text { A. tridentata } \\
\text { Cercocarpus ledifolius } \\
\text { Chrysothamns nauseosus } \\
\text { Junipems scopulomm } \\
\text { Rhus trilobata }\end{array}$ & $\begin{array}{l}\mathrm{p}^{3} \\
19 \\
\mathrm{p}\end{array}$ & $\begin{array}{l}* \\
* * \\
+ \\
+\end{array}$ \\
\hline \multicolumn{3}{|l|}{ Low Shrubs } \\
\hline $\begin{array}{l}\text { Artemisia frigida } \\
\text { Eurotia lanata } \\
\text { Gutierrezia sarothrae } \\
\text { Opuntia polyacantha }\end{array}$ & $\begin{array}{l}2 \\
7 \\
p\end{array}$ & $\begin{array}{l}* \\
+ \\
*\end{array}$ \\
\hline \multicolumn{3}{|l|}{ Graminoids } \\
\hline $\begin{array}{l}\text { Agropyron spicatum } \\
\text { Aristida longiseta } \\
\text { Bouteloua gracilis } \\
\text { Carex filifolia } \\
\text { C. stenophylla } \\
\text { Koeleria cristata } \\
\text { Oryzopsis hymenoides } \\
\text { Poa sandbergii } \\
\text { Stipa comata }\end{array}$ & $\begin{array}{l}9 \\
\mathrm{p} \\
\mathrm{p} \\
1 \\
\mathrm{p} \\
1 \\
\mathrm{p} \\
7\end{array}$ & * \\
\hline \multicolumn{3}{|l|}{ Forbs } \\
\hline $\begin{array}{l}\text { Allium cernum } \\
\text { Antennaria rosea } \\
\text { Comandra umbellata } \\
\text { Draba oligosperma } \\
\text { Erigeron caespitosa } \\
\text { Eriogonum microthecum } \\
\text { E. umbellatum } \\
\text { Happlopappus acaulis } \\
\text { Lesquerella alpine } \\
\text { Linum perenne } \\
\text { Lithospermum muderale } \\
\text { Mamillaria missouriensis } \\
\text { Petrophytum caespitosum } \\
\text { Phlox albomarginata } \\
\text { P. hoodii }\end{array}$ & $\begin{array}{l}\mathrm{p} \\
\mathrm{p} \\
\mathrm{p} \\
\mathrm{p} \\
\mathrm{p} \\
\mathrm{1}\end{array}$ & $\begin{array}{l}* \\
+ \\
*\end{array}$ \\
\hline
\end{tabular}
h.t.

${ }^{1}$ Intensive plot data for species constancy average canopy cover in the CELE/AGSP

${ }^{2}$ General reconnaissance data for average canopy cover in the CELE/AGSP h.t. (+ = $<1 \% ; *=1-10 \% ; * *=10-20 \% ; * * *=>20 \%$ ).

${ }^{3} \mathrm{p}=$ present with 1 ess than 0.5 percent canopy cover. 


\section{E12. - Rhus trilobata Series}

Species constancy (in parentheses) and average canopy cover for important species in the Rhus trizobata/Agropyron spicatum h.t. (RHTR/AGSP), and in the R. trilobata/Festuca idahoensis h.t. (RHTR/FEID)

\begin{tabular}{lcc}
\hline Species & RHTR/AGSP & RHTR/FEID \\
\hline
\end{tabular}

Medium Shrubs

Amelanchier alnifolia

Artemisia tridentata

Chrysothamnus nauseosus

C. viscidifloms

Juniperus scopulorum

Prunus virginiana

Rhus trizobata

Ribes cereum

Rosa arkansana

$\begin{array}{rrr}(25) & \mathrm{p}^{1} & -- \\ (25) & \mathrm{p} & -- \\ (75) & \mathrm{p} & -- \\ (25) & \mathrm{p} & -- \\ (25) & \mathrm{p} & -- \\ (50) & 1 & -- \\ (100) & 23 & 14 \\ (25) & 1 & -- \\ -- & & \mathrm{p}\end{array}$

Low Shrubs

Artemisia campestris

A. dracunculus

A. frigida

Junipems horizontalis

opuntia polyacantha

$\begin{array}{rrr}(25) & p & p \\ (25) & p & -- \\ (75) & 1 & 3 \\ -- & & p \\ (100) & p & --\end{array}$

Graminoids

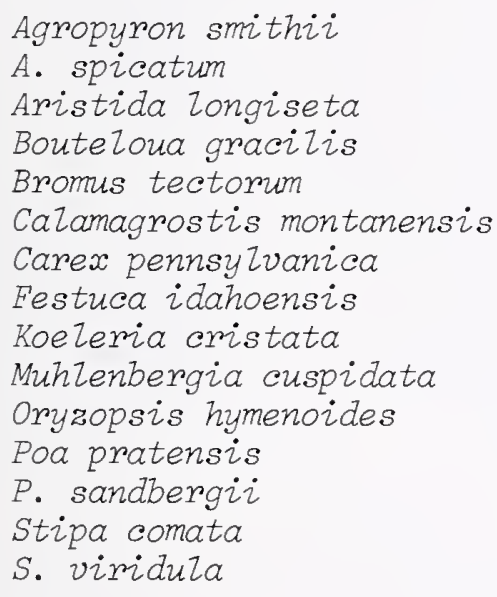

$\begin{array}{rrr}(25) & 1 & -- \\ (100) & 41 & 18 \\ -- & & 1 \\ -- & & 4 \\ (100) & 4 & p \\ -- & & p \\ -- & & 3 \\ -- & & 6 \\ (25) & p & 1 \\ -- & & 1 \\ (25) & 5 & -- \\ -- & & 3 \\ (25) & p & -- \\ -- & & 4 \\ (25) & p & p\end{array}$

Forbs

Achizlea milzefolium

Aliium cermuum

Antennamia parvifolia

Aster faicatus

Astragalus drummondii

Besseya wyomingensis

Cerastium arvense

Chaenactis douglasii

Chrysopsis vizlosa

Cirsium unduzatum

$\begin{array}{rlr}(75) & p & 3 \\ -- & & 1 \\ -- & & 1 \\ (25) & p & -- \\ (25) & p & -- \\ (25) & p & 1 \\ -- & & 2 \\ (25) & p & -- \\ (75) & 1 & 9 \\ (75) & p & p\end{array}$

(con.) 


\begin{tabular}{|c|c|c|c|}
\hline \multirow[b]{2}{*}{ Species } & \multicolumn{2}{|c|}{ RHTR/AGSP } & RHTR/EEID \\
\hline & (4 sta & nds ) & (1 stand) \\
\hline \multicolumn{4}{|l|}{ Forbs (con.) } \\
\hline Comandra umberlata & $(25)$ & $\mathrm{p}$ & $\mathrm{p}$ \\
\hline Erigeron caespitosus & -- & & p \\
\hline E. pumizis & (25) & $\mathrm{p}$ & -- \\
\hline Erysimum inconspicuum & (25) & p & -- \\
\hline Gaizlardia amistata & - & & 1 \\
\hline Gaura coccinea & $(50)$ & $\mathrm{p}$ & $\mathrm{p}$ \\
\hline Geum triflorum & - & & 1 \\
\hline Haplopappus acaulis & $(25)$ & $\mathrm{p}$ & -- \\
\hline H. nuttalzii & $(25)$ & $\mathrm{p}$ & -- \\
\hline Lepidium spp. & -- & & $\mathrm{p}$ \\
\hline Liatris punctata & $(25)$ & $\mathrm{p}$ & 1 \\
\hline Linum perenne & (25) & $\mathrm{p}$ & $\mathrm{p}$ \\
\hline Melizotus officinalis & $(50)$ & 1 & - \\
\hline Mentzelia dispersa & $(50)$ & $\mathrm{p}$ & -- \\
\hline Petalostemon purpureum & (25) & $\mathrm{p}$ & 1 \\
\hline Phlox albomarginata & $(25)$ & $p$ & -- \\
\hline P. hoodii & $(25)$ & $\mathrm{p}$ & 2 \\
\hline Plantago purshii & -- & & $\mathrm{p}$ \\
\hline Potentizia arguta & -- & & $\mathrm{p}$ \\
\hline P. hippeana & -- & & $\mathrm{p}$ \\
\hline Psoralea tenuiflora & $(50)$ & 1 & -- \\
\hline Ratibida columnifera & -- & & $\mathrm{p}$ \\
\hline Senecio canus & $(25)$ & $\mathrm{p}$ & -- \\
\hline Solidago missouriensis & -- & & $\mathrm{p}$ \\
\hline Sphaeralcea coccinea & $(75)$ & $\mathrm{p}$ & -- \\
\hline Taraxacum officinale & -- & & $\mathrm{p}$ \\
\hline Thermopsis rhombifolia & -- & & $\mathrm{p}$ \\
\hline Tragopogon dubius & $(50)$ & 1 & $\mathrm{p}$ \\
\hline Vicia americana & $(75)$ & 2 & - \\
\hline
\end{tabular}

$I_{p}=$ present with less than 0.5 percent canopy cover. 


\section{E13. - Sarcobatus vermiculatus Series}

Average canopy cover for important plants in the Sarcobatus vermiculatus/Agropyron smithii h.t. (SAVE/AGSM), and S. vermiculatus/Elymus cinereus h.t. (SAVE/ELCI)

Species $\frac{S A V E / A G S M}{\text { SAVE/ELCI }} \frac{(1 \text { stand })^{1}(2 \text { stands })^{2}}{(2 \text { stands })^{2}}$

Medium Shrubs

\begin{abstract}
Atriplex nuttalzii
chrysothamnus viscidifloms

Sarcobatus vermiculatus
\end{abstract}

Low Shrubs

$$
\begin{aligned}
& \text { Artemisia frigida } \\
& \text { Gutierrezia sorathrae } \\
& \text { opuntia polyacantha }
\end{aligned}
$$

Graminoids
Agropyron smithii
A. spicatum
Bouteloua gracilis
Bromus tectorum
Carex filifolia
Elymus cinereus
Koeleria cristata
Poa juncifolia
P. pratensis
Stipa comata
S. viridula

55

5

3

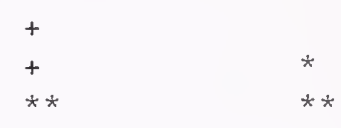

Forbs
Aster chilensis
Chenopodium spp.
Comandra umbellata
Iva axizzaris
Tragopogon dubius
Sphaeralcea coccinea

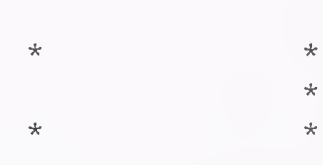

2

*

${ }^{1}$ Intensive plot data for average canopy cover in the $S A V E / A G S M$ h.t.

${ }^{2}$ General reconnaissance data for average canopy cover in the SAVE/AGSM and SAVE/ELCI habitat types $(+=<1 \% ; *=1-10 \% ; * *=10-20 \% ; * * *=>20 \%)$. 


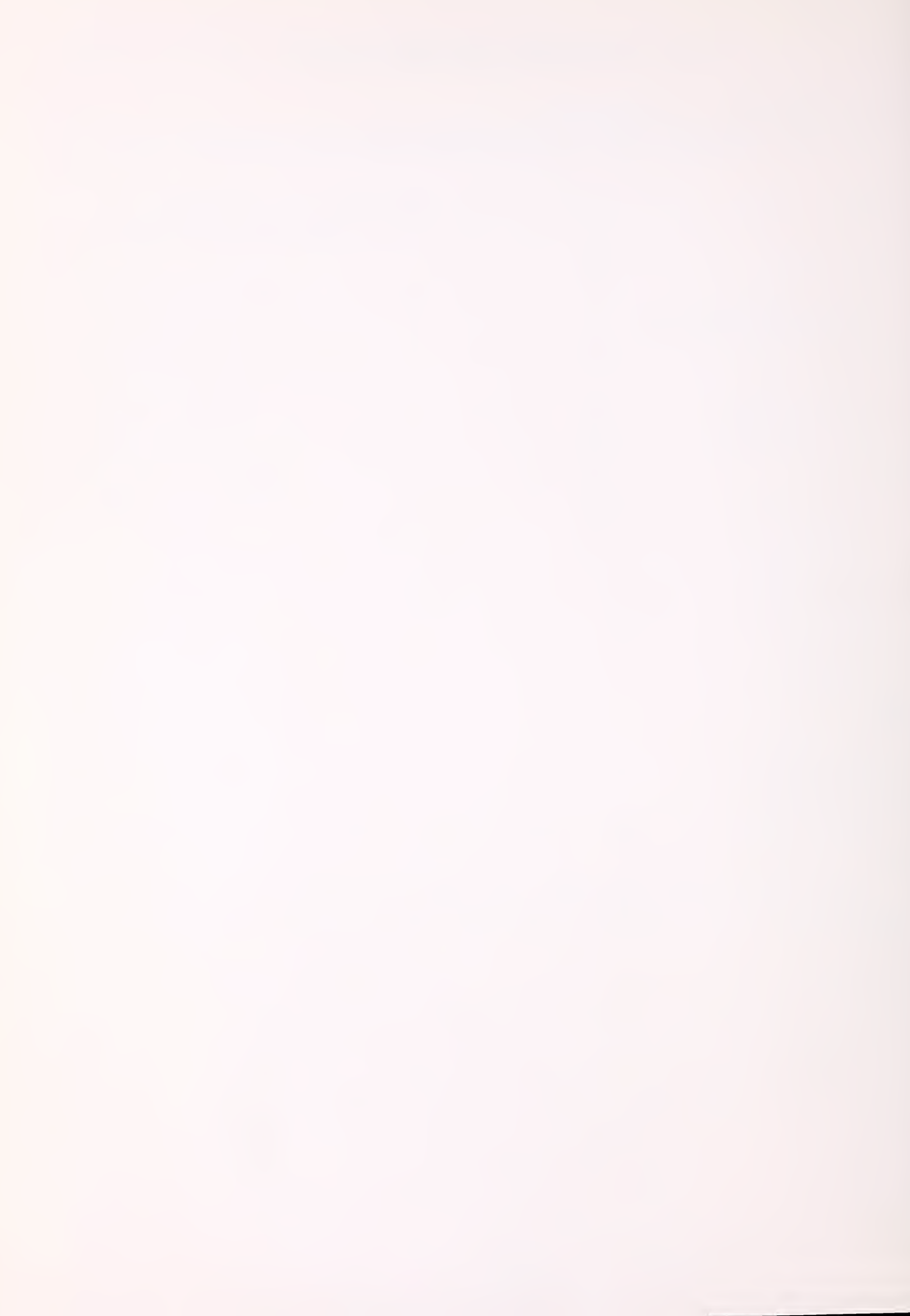




\section{APPENDIX F}




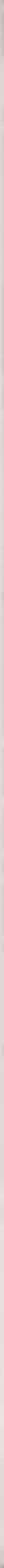




\section{APPENDIX F -}

\section{PALATABILITY RATINGS}

Palatability ratings for important plants in grassland and shrubland habitat types of western Montana have been compiled from published literature and guides for range managers ${ }^{1}$

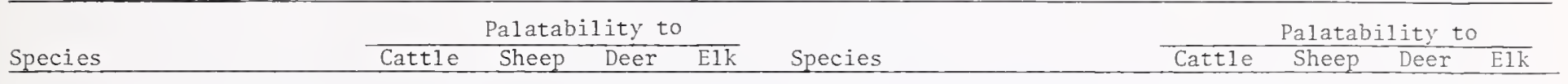

Medium Shrubs

\begin{tabular}{|c|c|c|c|c|}
\hline Artemisia arbuscula & $\mathrm{P}-\mathrm{F}$ & $F-G$ & $\mathrm{~F}$ & 0 \\
\hline A. tmidentata & VP & $\mathrm{P}$ & $P-G$ & $\mathrm{P}-\mathrm{F}$ \\
\hline A. tmipartita & VP & VP & $\mathrm{F}$ & $\mathrm{P}-\mathrm{F}$ \\
\hline Cercocarpus ledijolius & $\mathrm{F}$ & $\mathrm{F}$ & $G-E$ & $-E$ \\
\hline Chrysothommus nauseosus & VP & VP & VP & $P$ \\
\hline C. vicidifloms & $\mathrm{F}$ & $F-G$ & $F-G$ & \\
\hline Junipems scopuzomm & VP & $\mathrm{P}$ & $\mathrm{P}-\mathrm{F}$ & \\
\hline Potentilza fmiticosa & $\mathrm{p}$ & $\mathrm{P}-\mathrm{F}$ & $P-F$ & \\
\hline Pminus virginiana & $P-F$ & $P-F$ & G & \\
\hline Purshia tridentata & $F-G$ & $F-G$ & E & \\
\hline Rhus tmizobata & VP & VP & $F-G$ & \\
\hline Ribes cereum & $\mathrm{P}$ & $P-F$ & $\mathrm{~F}$ & \\
\hline Rosa arkansana & $\mathrm{P}-\mathrm{F}$ & $\mathrm{F}$ & $F-G$ & $\mathrm{~F}-\mathrm{C}$ \\
\hline Sarcobatus vermiculatus & VP & PO & VP & $\mathrm{VH}$ \\
\hline Tetradymia canescens & $V P$ & PO & VP & $\mathrm{VE}$ \\
\hline
\end{tabular}

Low Shrubs

Arctostaphylos uva-ursi Artemisia frigida

Eurotia Zanata

Gutiemezia sarothrae

Junipems homizontalis

opuntia polyacantha

Vaccinium scopamium

Graminoids

Agropyron caninum

A. dasystachyum

A. smithii

A. spicatron

Agrostis diegoensis

A. humilis

A. scabra

Alopecums pratensis

Amistida Zonaiseta

Bouteloua gracilis

Bromes anomalus

$B$. caminatus

B. ciliatus

B. tectomom

Calamagrostis montanensis $\mathrm{F}$

C. purpurescens

C. mbescens

Carex albonigra

C. athrostachya

c. capizlamis

$\begin{array}{rrrr}P & P & F & F \\ P-F & F & F & F \\ G & G & G & G \\ V P & V P & V P & V P \\ V P & P & P-F & P \\ V P & V P & V P & V P \\ P & P-F & P-F & F-G\end{array}$

$G-G$
$E$
$E$
$V G$
$V G$
$G$
$F$
$F$
$V G$
$E$
$E$
$E$
$F$
$F-G$
$F-G$
$P-F$
$P-F$
$F-G$
$F$
C. fizifolia

C. hoodii

C. obtusata

C. pachystachya

C. pennsyzuanica

C. petasata

C. platylepis

c. raynoldsii

C. scopulomm

C. stenophyzza

C. vallicola

Danthonia intermedia

D. parmi

Deschompsia caespitosa

Elyms cinereus

Festuca idahoensis

F. octoflora

F. scabrelza

Helictotrichon hookem

Hesperochloa kingii

Juncus balticus

c. mertensianus

J. parmi

Koelemia mistata

Luzula parvifiora

L. spicata

llelica bulbosa

M. spectabilis

Whienbergia cuspidata

M. Michardsonii

Omyzopsis hymenoides

Phieum alpinum

P. pratense

Poa cusicki

P. intemior

$P$. juncifolia

P. pratensis

$P$. sandbergi

Sporobolus cmptandms

Stipa comata

S. occidentalis

S. michardsoni $i$

S. spartea

S. viridula

Trisetum spicatum

T. wolfii

\begin{tabular}{|c|c|c|c|}
\hline$F$ & G & F & F \\
\hline$F-G$ & F & F & $F-G$ \\
\hline$F-G$ & $F-G$ & $F-G$ & $F-G$ \\
\hline G & G & G & G \\
\hline$F-G$ & $F-G$ & $F-G$ & $F-G$ \\
\hline G & G & G & G \\
\hline F & $F-G$ & $F-G$ & $F-G$ \\
\hline$F-G$ & F & F & $F-G$ \\
\hline$F$ & F & $\mathrm{F}$ & F \\
\hline $\mathrm{F}$ & F & $\mathrm{F}$ & $\mathrm{F}$ \\
\hline G & G & G & G \\
\hline G & G & $\mathrm{F}$ & G \\
\hline $\mathrm{F}$ & $\mathrm{F}$ & $\mathrm{F}$ & $\mathrm{F}$ \\
\hline G & G & G & G \\
\hline$P-F$ & $\mathrm{P}$ & P & $\mathrm{P}-\mathrm{F}$ \\
\hline $\mathrm{G}-\mathrm{VG}$ & G-VG & $G-V G$ & $\mathrm{G}-\mathrm{E}$ \\
\hline$F-G$ & G & G & $F-G$ \\
\hline VG & F & $\mathrm{F}$ & VG \\
\hline$F-G$ & $\mathrm{~F}$ & $\mathrm{~F}$ & G \\
\hline$F-G$ & F & F & $F-G$ \\
\hline G & $F-G$ & F & F \\
\hline F & F & F & F \\
\hline F & $F-G$ & $F-G$ & G \\
\hline G & G & G & G \\
\hline$F-G$ & $P-F$ & F & G \\
\hline F & $P-F$ & $\mathrm{~F}$ & G \\
\hline G-E & G & $F-G$ & G \\
\hline$G-E$ & G & $F-G$ & G \\
\hline F & F & $\mathrm{F}$ & $\mathrm{F}$ \\
\hline G & F & F & F \\
\hline $\mathrm{G}-\mathrm{VG}$ & $G-V^{T} G$ & $G-V G$ & $G-V G$ \\
\hline$G-V G$ & $F-G$ & $G-V G$ & $\mathrm{G}-\mathrm{VG}$ \\
\hline VG & G & F & $V G$ \\
\hline G & G & G & G \\
\hline$F-G$ & $F-G$ & $F-G$ & $F-G$ \\
\hline G & G & $F-G$ & G \\
\hline VG & VG & G & G \\
\hline G & G & G & G \\
\hline G & $F-G$ & $\mathrm{~F}$ & $F-G$ \\
\hline$F-G$ & F & $\mathrm{F}$ & $\mathrm{F}-\mathrm{G}$ \\
\hline G & G & $\mathrm{F}$ & $\mathrm{F}-\mathrm{G}$ \\
\hline $\mathrm{G}$ & $\mathrm{G}$ & F & $F-G$ \\
\hline $\mathrm{F}$ & $\mathrm{F}$ & F & F \\
\hline G & G & G & G \\
\hline G & $\mathrm{P}-\mathrm{F}$ & $P-F$ & $F-G$ \\
\hline$F-G$ & F & F & F \\
\hline
\end{tabular}

(con.) 


\begin{tabular}{|c|c|c|c|c|c|c|c|c|c|}
\hline \multirow{2}{*}{ Species } & \multicolumn{4}{|c|}{ Palatability To } & \multirow[b]{2}{*}{ Species } & \multicolumn{4}{|c|}{ Palatability To } \\
\hline & Cattle & Sheep & Deer & $\mathrm{E} 1 \mathrm{k}$ & & Catt le & Sheep & Deer & E1k \\
\hline \multicolumn{10}{|l|}{ Forbs } \\
\hline Achizrea mizreforium & $\mathrm{P}-\mathrm{F}$ & P-F & $P-F$ & $P-F$ & Geum rossii & VP & $\mathrm{P}-\mathrm{F}$ & $P \sim F$ & VP \\
\hline Agosemis glauca & F & G-VG & G & G & G. triflomum & VP & VP & VP & VP \\
\hline A. grandiflora & $\mathrm{F}$ & $F-G$ & $F-G$ & $F-G$ & Haplopappus acaulis & VP & $\mathrm{P}$ & $\mathrm{P}$ & $\mathrm{P}$ \\
\hline AZZium cermuum & $\mathrm{F}$ & G & G & G & Hedysarwo spp. & G & G & G & G \\
\hline Anaphalis margaritacea & $\mathrm{P}$ & $P-F$ & $\mathrm{~F}$ & $\mathrm{~F}$ & Helianthe Ila uniflora & $\mathrm{P}-\mathrm{F}$ & $F-G$ & $\mathrm{~F}-\mathrm{G}$ & $\mathrm{P}-\mathrm{F}$ \\
\hline Anemone patens & VP & $\mathrm{P}-\mathrm{F}$ & $\mathrm{P}-\mathrm{F}$ & $P-F$ & Heuchera spp. & $\mathrm{P}$ & $\mathrm{P}$ & $\mathrm{P}$ & $\mathrm{P}$ \\
\hline Antennaria anaphazoides & $\mathrm{P}$ & $\mathrm{F}$ & $\mathrm{F}$ & $\mathrm{P}$ & Hieracium azbertinum & $\mathrm{F}$ & G & G & G \\
\hline A. corymbosa & $\mathrm{P}$ & $\mathrm{F}$ & $\mathrm{F}$ & $\mathrm{P}$ & Hymenoxys acaulis & VP & VP & VP & $V P$ \\
\hline A. parvifolia & $\mathrm{P}$ & $\mathrm{F}$ & $\mathrm{F}$ & $\mathrm{P}$ & Lepedium spp. & $\mathrm{P}$ & $\mathrm{p}$ & $\mathrm{P}$ & $\mathrm{P}$ \\
\hline A. rosea & $\mathrm{p}$ & $\mathrm{F}$ & $\mathrm{F}$ & $\mathrm{P}$ & Liatris punctata & $\mathrm{P}$ & $P-F$ & $\mathrm{P}-\mathrm{F}$ & $\mathrm{P}$ \\
\hline Arenaria congesta & $\mathrm{P}-\mathrm{F}$ & $\mathrm{F}$ & $\mathrm{F}$ & $\mathrm{P}-\mathrm{F}$ & Linum perenne & $P-F$ & $F$ & $\mathrm{~F}$ & $\mathrm{~F}$ \\
\hline Amica chamissonis & VP & VP & VP & VP & Lithospermum muderale & VP & $\mathrm{P}$ & $\mathrm{P}$ & $\mathrm{p}$ \\
\hline A. fulgens & $\mathrm{P}$ & $\mathrm{P}$ & P & P & Lomatium twitematum & $P-F$ & $F-G$ & G & G \\
\hline A. soromia & VP & VP & $V P$ & VP & Lupinus argenteus & $\mathrm{P}$ & PO & VP & VP \\
\hline Artemisia Zudoviciana & VP & $P-F$ & $\mathrm{P}$ & $\mathrm{P}$ & L. serecius & $\mathrm{P}$ & PO & VP & $V P$ \\
\hline Aster campestris & $\mathrm{P}$ & $\mathrm{P}$ & $P-F$ & $\mathrm{P}-\mathrm{F}$ & L. wyethia & $P-F$ & P-F & $P-F$ & $P-F$ \\
\hline A. falcatus & $\mathrm{P}$ & $\mathrm{P}$ & $\mathrm{P}$ & $\mathrm{P}$ & Melizotus officinalis & G-VG & G-VG & G-VG & G-VG \\
\hline A. foliaceus & $\mathrm{P}$ & $\mathrm{F}$ & $\mathrm{F}$ & $F-G$ & Monarda fistulosa & $P-F$ & $\mathrm{~F}$ & F & $\mathrm{F}$ \\
\hline A. integrifolius & $\mathrm{P}$ & $\mathrm{P}$ & $\mathrm{F}$ & $F-G$ & oxytropis besseyi & $\mathrm{F}$ & $\mathrm{F}$ & $\mathrm{F}$ & $\mathrm{F}$ \\
\hline Astragalus dmumondii & G & G & G & G & o. sericea & PO & PO & PO & $\mathrm{PO}$ \\
\hline A. miser praeteritus & G & G & G & G & o. vicida & VP & VP & VP & VP \\
\hline A. purshii & VP & $V P$ & $V P$ & VP & Pediculamis contorta & $\mathrm{P}$ & $P-F$ & $P-F$ & $\mathrm{P}-\mathrm{F}$ \\
\hline Balsamorhiza incana & F & F & $\mathrm{F}$ & $\mathrm{F}$ & Penstemon procems & $\mathrm{P}$ & $\mathrm{F}$ & $\mathrm{F}$ & $\mathrm{F}$ \\
\hline B. sagittata & $F-G$ & $F-G$ & VG & VG & Phzox albomarginata & VP & VP & VP & VP \\
\hline Besseya wyomingensis & $\mathrm{P}$ & $\mathrm{F}$ & $\mathrm{F}$ & $\mathrm{P}$ & P. hoodii & $V P$ & VP & VP & VP \\
\hline Camassia quamash & F & $F-G$ & $F-G$ & F & P. ketseyi & $\mathrm{P}$ & P-F & $P-F$ & $\mathrm{P}$ \\
\hline Campanula rotundifolia & $\mathrm{P}-\mathrm{F}$ & $\mathrm{P}-\mathrm{F}$ & $P-F$ & $\mathrm{P}-\mathrm{F}$ & P. Zongifolia & $\mathrm{P}$ & $\mathrm{P}-\mathrm{F}$ & $P-F$ & $\mathrm{P}$ \\
\hline Castizzeja angustifolia & $\mathrm{P}$ & $P-F$ & $P-F$ & $P-F$ & P. multiflora & $\mathrm{P}$ & $\mathrm{P}-\mathrm{F}$ & $P-F$ & $\mathrm{P}$ \\
\hline Cerastium arvense & VP & $\mathrm{P}$ & $\mathrm{P}$ & VP & P. pulvinata & VP & VP & VP & VP \\
\hline Chrysopsis vizzosa & $\mathrm{P}$ & $P-F$ & $F-G$ & $P-F$ & Plantago purshii & $\mathrm{P}$ & P & P & $\mathrm{P}$ \\
\hline Clematis hirsutissima & $\mathrm{P}$ & $\mathrm{P}$ & $\mathrm{P}$ & $\mathrm{P}$ & Polygonum bistortoides & VP & $\mathrm{P}$ & $\mathrm{P}$ & $\mathrm{P}$ \\
\hline Collinsia pamiflora & VP & VP & VP & $V P$ & P. douglasii & VP & $P-F$ & $\mathrm{P}$ & $\mathrm{P}$ \\
\hline Colzomia Zinearis & VP & VP & VP & VP & Potentizza arguta & $P-F$ & $F-G$ & $F-G$ & $\mathrm{~F}$ \\
\hline Comandra umbelzata & $\mathrm{P}$ & $\mathrm{F}$ & $\mathrm{F}$ & $\mathrm{P}-\mathrm{F}$ & P. diversifolia & $V P$ & $\mathrm{~F}$ & F & $\mathrm{F}$ \\
\hline Crepis occidentatis & $\mathrm{F}$ & G & G & G & P. glanduiosa & $\mathrm{P}$ & $P-F$ & $\mathrm{P}-\mathrm{F}$ & $P-F$ \\
\hline Cymoptemus bipinnata & $\mathrm{P}$ & $\mathrm{P}-\mathrm{F}$ & $P-F$ & $P-F$ & P. gracilis & $V P$ & $\mathrm{P}$ & $\mathrm{P}$ & $\mathrm{P}$ \\
\hline Delphinium bicolor & PO & $F-G$ & F & $\mathrm{F}$ & Psoralea tenufolia & VP & $\mathrm{P}$ & $\mathrm{P}$ & VP \\
\hline D. occidentale & PO & $F-G$ & $\mathrm{~F}$ & $\mathrm{~F}$ & Rumex salicifolius & $P-F$ & $\mathrm{~F}$ & $\mathrm{~F}$ & $\mathrm{~F}$ \\
\hline Epizobium minutum & $\mathrm{P}$ & $\mathrm{P}$ & $\mathrm{P}$ & $P$ & Sedum Zaneeolatum & $V P$ & VP & VP & VP \\
\hline Erigeron caespitosus & $\mathrm{P}$ & $\mathrm{P}$ & $\mathrm{P}$ & $\mathrm{P}$ & Senecio cana & $P-F$ & F & F & $P-F$ \\
\hline E. compositus & $\mathrm{P}$ & $P-F$ & $\mathrm{~F}$ & $\mathrm{~F}$ & s. integerimus & $\mathrm{p}$ & F & F & $\mathrm{F}$ \\
\hline E. corymbosus & $\mathrm{P}$ & $P-F$ & $\mathrm{~F}$ & $\mathrm{~F}$ & Solidago missoumiensis & $\mathrm{P}$ & $P-F$ & $P-F$ & $\mathrm{P}$ \\
\hline E. fizifolius & $\mathrm{P}$ & $\mathrm{P}$ & $\mathrm{P}$ & $\mathrm{P}$ & Sphaeratcea coccinea & $\mathrm{P}$ & $\mathrm{P}$ & $\mathrm{P}$ & $\mathrm{P}$ \\
\hline E. speciosus & $\mathrm{P}$ & $\mathrm{P}-\mathrm{F}$ & $\mathrm{F}$ & $\mathrm{F}$ & Stezzaria spp. & $\mathrm{F}$ & $F-G$ & $F-G$ & $F-G$ \\
\hline E. subtrinervis & $\mathrm{P}$ & $\mathrm{P}-\mathrm{F}$ & $\mathrm{F}$ & $\mathrm{F}$ & Taraxacum officinale & $F-G$ & G & G & G \\
\hline E. tweedyi & $\mathrm{P}$ & $P-F$ & $\mathrm{~F}$ & $\mathrm{~F}$ & Thermopsis rhombifolia & $\mathrm{P}$ & $\mathrm{P}$ & $P$ & $\mathrm{P}$ \\
\hline Eriogonum umbelzatum & $\mathrm{P}$ & $P-G$ & $\mathrm{~F}$ & $\mathrm{~F}$ & Tragopogon dubius & $\mathrm{P}$ & $\mathrm{F}$ & $\mathrm{F}$ & $\mathrm{F}$ \\
\hline Frasera speciosa & $\mathrm{F}$ & $F-G$ & $F-G$ & $\mathrm{~F}-\mathrm{G}$ & Veronica wormskjoldi & $\mathrm{P}$ & $\mathrm{P}-\mathrm{F}$ & $\mathrm{P}-\mathrm{F}$ & $\mathrm{P}$ \\
\hline Gailzardia amistata & $\mathrm{P}-\mathrm{F}$ & $\mathrm{F}$ & $\mathrm{F}$ & $\mathrm{P}-\mathrm{F}$ & Vicia americana & $\mathrm{G}-\mathrm{E}$ & $G-E$ & G-E & $G-E$ \\
\hline Galium boreale & $\mathrm{P}$ & F & F & $\mathrm{P}$ & Viola adunea & $\mathrm{F}$ & $\mathrm{F}$ & $\mathrm{F}$ & $\mathrm{F}$ \\
\hline Gentiana affinis & $\mathrm{P}$ & $P-F$ & $P-F$ & $P-F$ & Zigadenus elegans & $\mathrm{P}$ & $\mathrm{PO}$ & $\mathrm{P}$ & $\mathrm{P}$ \\
\hline Geranium viscosissimom & $F-G$ & G & G & F & 2. venenosus & $\mathrm{P}$ & PO & $\mathrm{P}$ & $\mathrm{P}$ \\
\hline
\end{tabular}

${ }^{1} \mathrm{E}=$ excellent; $V G=$ very good $G=$ good $F=$ fair $; P=$ poor $; V P=$ very poor; $P O=$ poisonous. 
APPENDIX G -

COMPARISONS OF DIFFERENTIALLY. GRAZED

PAIRED STANDS 


\section{G1. - Stipa comata Series}

Canopy cover and confidence levels of differentially grazed paired stands in the Stipa comata series

\begin{tabular}{|c|c|c|c|c|c|}
\hline \multirow[t]{4}{*}{ Type of cover } & \multicolumn{2}{|c|}{$S T C O / B O G R$} & \multicolumn{3}{|c|}{$\begin{array}{l}S T C O / B O G R \\
A G S M \text { phase }\end{array}$} \\
\hline & Stand 102 & Stand 103 & \multicolumn{2}{|c|}{ Stand 167} & Stand 16 \\
\hline & \multicolumn{5}{|c|}{ Grazing } \\
\hline & (none) & (heavy) & (slig) & & (moderat \\
\hline & ---1 & $---\overline{P e r}$ & $t--$ & - & ---- \\
\hline \multicolumn{6}{|l|}{ Cover class } \\
\hline Shrubs & 3.8 & 5.2 & 8.3 & $\star 2$ & 13.4 \\
\hline Graminoids & 61.3 & 57.8 & 72.6 & ** & 60.2 \\
\hline Forbs & 0.2 & 0.2 & 11.1 & & 8.6 \\
\hline Bryophytes & $10.8 *$ & 6.8 & 14.1 & + & 16.1 \\
\hline Bare ground & 19.2 & 23.1 & 5.0 & ** & 16.1 \\
\hline Litter & 2.7 & 3.4 & 69.8 & ** & 48.2 \\
\hline Rock & 7.1 & 5.1 & 13.7 & $* *$ & 1.1 \\
\hline
\end{tabular}

Shrubs

Artemisia frigida

Chrysothamnus nauseosus

Gutierrezia sarothrae

Eurotia lanata

opuntia polyacantha

Graminoids

Agropyron smithii

A. spicatum

Bouteloua gracilis

Catamagrostis montanensis

Carex filifolia

C. stenophylla

Koeleria cristata

Poa sandbergii

Sitanion hysterix

Stipa comata

Forbs

Astragalus ceramicus

A. dmomondii

A. purshii

Hymenoxys acaulis

Liatris punctata

Lygodesmia juncea

Melizotus officinalis

Paronychia sessiliflora

Phlox hoodii

Sphaeralcia coccinea

The lesperma marginatum

$\begin{array}{cccr}\mathrm{p}^{3} & & 7.6+ & 10.1 \\ \mathrm{p} & & & 1.9 \\ \mathrm{p} & 0.8 & 0.8 & 0.7 \\ 3.8 & \mathrm{p} & & 0.4 \\ & 4.4 & & \end{array}$

\begin{tabular}{|c|c|c|c|c|}
\hline & & 3.5 & + & 1.6 \\
\hline & & 0.4 & & 0.1 \\
\hline 53.9 & 54.7 & 8.9 & $\star *$ & 22.6 \\
\hline & & 4.3 & $* *$ & 9.7 \\
\hline & & 20.0 & $* *$ & 9.0 \\
\hline 10.3 & 9.2 & 1.0 & $* *$ & 4.0 \\
\hline & & 6.6 & $* *$ & 0.6 \\
\hline & & $\mathrm{p}$ & + & 0.8 \\
\hline 0.4 & & & & \\
\hline $9.6 *$ & 3.3 & 29.3 & $* *$ & 7.6 \\
\hline
\end{tabular}

${ }^{1}$ See the narrative in appendix G6 for the location and history of these stands.

${ }^{2}$ Confidence levels $(* *=>99 \% ; *=95-98 \% ;+=90-94 \%$ probability of differing statistically).

${ }^{3} \mathrm{p}=$ present with less than 0.5 percent canopy cover. 


\section{G2. - Agropyron spicatum Series}

Canopy cover and confidence levels of differentially grazed paired stands in the Agropyron spicatum series ${ }^{1}$

\begin{tabular}{|c|c|c|c|c|}
\hline \multirow{3}{*}{ Type of cover } & $A G S P / B O G R$ & $\overline{A G S P} / B O G R$ & $A G S P / B O G R$ & AGSP/AGSM \\
\hline & Stand 107 Stand 108 & $\begin{array}{r}\text { Stand } 16 \text { Stand } 17 \\
\end{array}$ & $\begin{array}{l}\text { Stand } 13 \text { Stand } 12 \\
\text { zing }\end{array}$ & Stand 194 Stand 195 \\
\hline & (moderate) & (heavy) & (moderate) & (moderate) \\
\hline
\end{tabular}

Cover class

$\begin{array}{lcr}\text { Shrubs } & 3.5 * * 214.6 \\ \text { Graminoids } & 44.6 * 36.5 \\ \text { Forbs } & \mathrm{P} & 0.7 \\ \text { Bryophytes } & 25.6 & 24.9 \\ \text { Bare ground } & 18.3 & 16.2 \\ \text { Litter } & 21.8+16.3 \\ \text { Rock } & 6.8 * * & 17.9\end{array}$

$1.8 \quad 1.6$

$40.7 \quad 39.6$

$12.8 \quad 10.6$

4.5

$30.0 * 42.1$

$17.4 * 11.6$

$1.6 \quad 1.8$

Shrubs

Artemisia frigida

Artemisia tridentata

Chrysothammus nauseosus

C. viscidifloms

Gutiemezia sarothrae

Juniperus horizontalis

Leptodactyzon pungens

opuntia polyacantha

Potentizla fruticosa

Rosa arkansana

$\begin{array}{cccc}2.5 & 4.5 & 8.2 & 6.8 \\ & & \mathrm{P} & 0.9 \\ & \mathrm{P} & 0.4 \\ & 0.8 & 0.1 \\ \mathrm{P} * * \quad 4.4 & 1.2 & 2.0 \\ & & & \\ & & & 0.4 \\ & & 1.0 & 0.1\end{array}$

0.4

Graminoids

Agropyron dasystachyum
A. spicatum
Bouteloua gracilis
Bromus tectomm
Calanagrostis montanensis
Carex filifolia
C. stenophylla
Helictotrichon hookeri
Koeleria cristata
Mullenbergia cuspidata
Poa cusickii
P. pratensis
P. sandbergii
Stipa comata
S. viridula

$3.0 \quad 4.3$

$2.3 * 5.1$

$\begin{array}{cr}P & 0.4 \\ 68.0 * * 45.7 \\ 19.1 & 15.3 \\ 21.6 & 17.7 \\ 1.6 * * & 5.8 \\ 22.1+27.5 \\ 3.2 & 4.5\end{array}$

$23.1 * * 10.0$

$76.2 * * 56.0$

$28.4 * * 65.7$

$11.7 * 1.4$

$1.4 * * 6.3$

$76.4 * * 63.7$

$8.9 * * 14.7$

$\begin{array}{rrr}0.9 * 3.2 & 15.6 * 3.4 \\ & 0.4 & \\ P \quad & 0.9 & 10.5 * * 1.4 \\ & & \end{array}$

P 2.1

0.1

$22.0 * * 10.4$

$14.6 * * 1.7 \quad 3.3+0.8$

$10.7 * 4.5$

2.6

$0.1+1.1$

$0.7 \quad 1.2$

$2.3 * 0.5$

$4.6 \quad 5.4$

$1.4 \quad 2.5$

$* * 13.7$

8.110 .2

$6.6 \quad 7.5$

1.9

$2.6 \quad 2.9$

$18.2 * * 30.2$
$9.9 * * 0.2$

$25.7 * *$

(con.) 
APPENDIX G2 (con.)

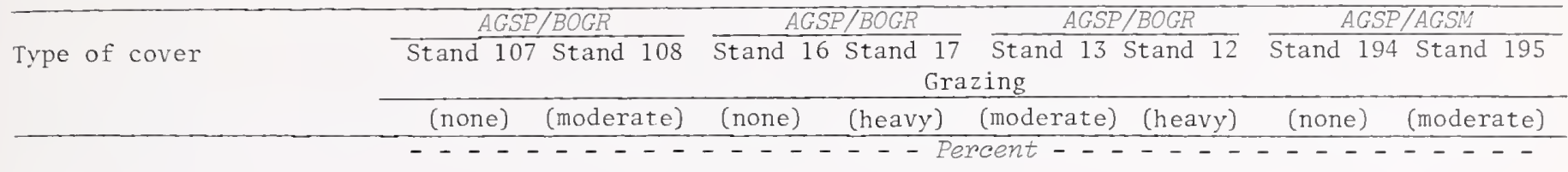

Forbs

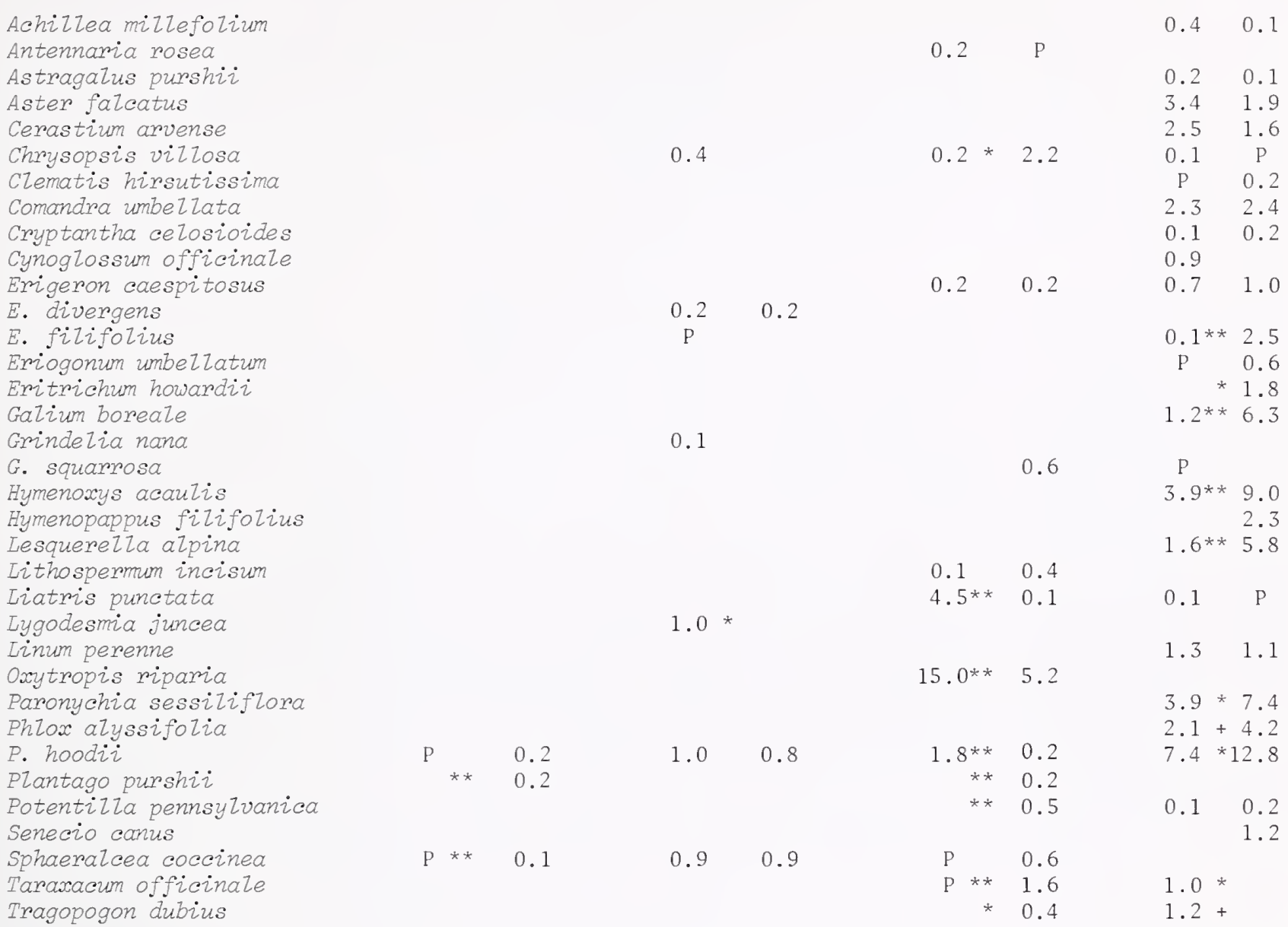

${ }^{1}$ See the narrative in appendix 66 for the location and history of these stands.

${ }^{2}$ Confidence levels $(* *=>99 \% ; *=95-98 \% ;+=90-94 \%$ probability of differing statistically). 


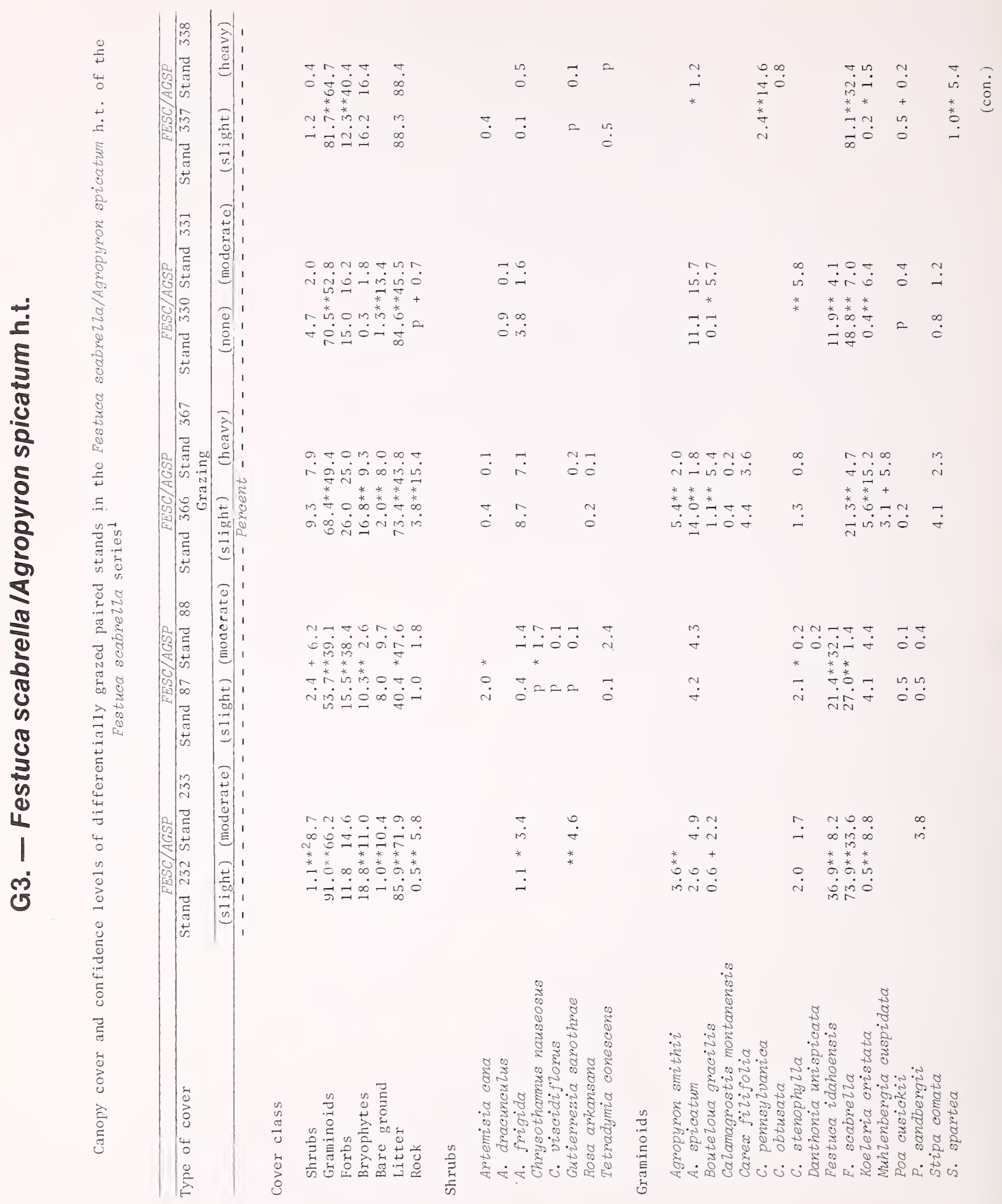




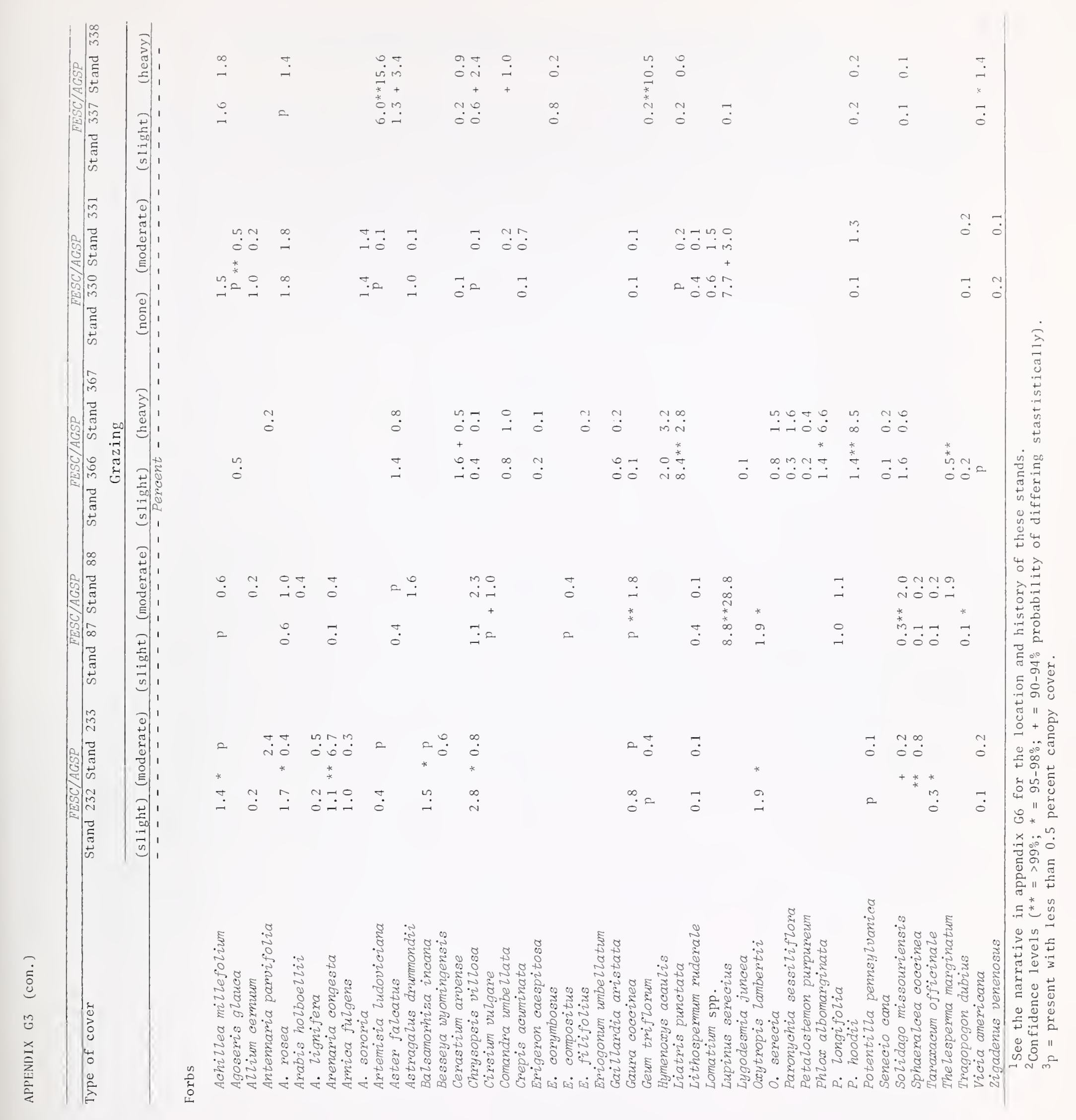




\section{G4. - Festuca scabrella /Festuca idahoensis h.t.}

Canopy cover and confidence levels of differentially grazed paired stands in the Festuca scabrelza/Eestuca idahoensis h.t. and the Geranium viscosissimum phase of the Festuca scabrezza series ${ }^{1}$

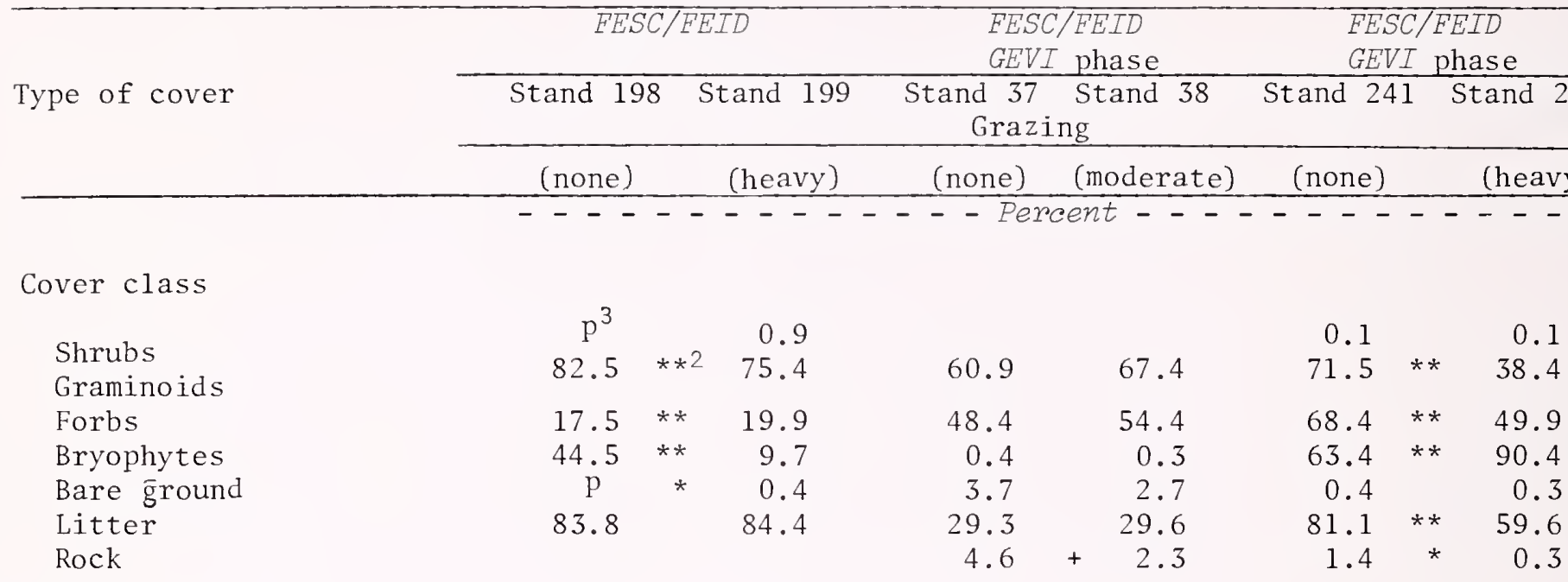

Shrubs

Artemisia tridentata $\quad$ p $\quad 0.9$

Graminoids

Agropyron dasystachyum
A. spicatum
Carex obtusata
C. petasata
C. valicola
Danthonia intermedia
D. unispicata
Festuca idahoensis
F. scabrella
Koeleria cristata
Poa juncifolia
P. pratensis
P. sandbergii
Stipa occidentalis

Forbs

Achizlea mizzefolium

Agosemis glauca

Alzium cermum

Anaphalis margaritacea

Anemone patens

Antennaria rosea

A. anaphaloides

Arenaria congesta

Arabis hirsuta

Amica fulgens

Artemisia Zudoviciana

Aster spp.

A. falcatus

\begin{tabular}{|c|c|c|c|c|c|c|c|c|}
\hline \multirow[t]{4}{*}{0.1} & & 0.8 & & & & & & \\
\hline & & & $\mathrm{p}$ & & 0.8 & 18.4 & $* *$ & 2.2 \\
\hline & & & 2.7 & $* *$ & 8.1 & & & \\
\hline & & & 1.0 & $* *$ & 3.4 & 2.0 & & 0.6 \\
\hline \multirow[t]{2}{*}{21.0} & $* *$ & 0.2 & & & & & & \\
\hline & & & & & 0.6 & $\mathrm{p}$ & & 1.7 \\
\hline 0.2 & $* *$ & 40.8 & & & 0.1 & & & \\
\hline 7.6 & $* *$ & 20.5 & 10.1 & * & 17.4 & 17.9 & & 17.1 \\
\hline \multirow[t]{2}{*}{71.1} & $* *$ & 4.3 & 44.6 & & 35.3 & 41.7 & $* *$ & 4.2 \\
\hline & & 1.8 & 1.6 & & 2.0 & 11.8 & * & 8.3 \\
\hline \multirow{3}{*}{11.0} & & & & & & 0.4 & & 1.3 \\
\hline & & & 0.4 & & 1.2 & & $* *$ & 6.6 \\
\hline & & & & & 0.8 & & & \\
\hline
\end{tabular}

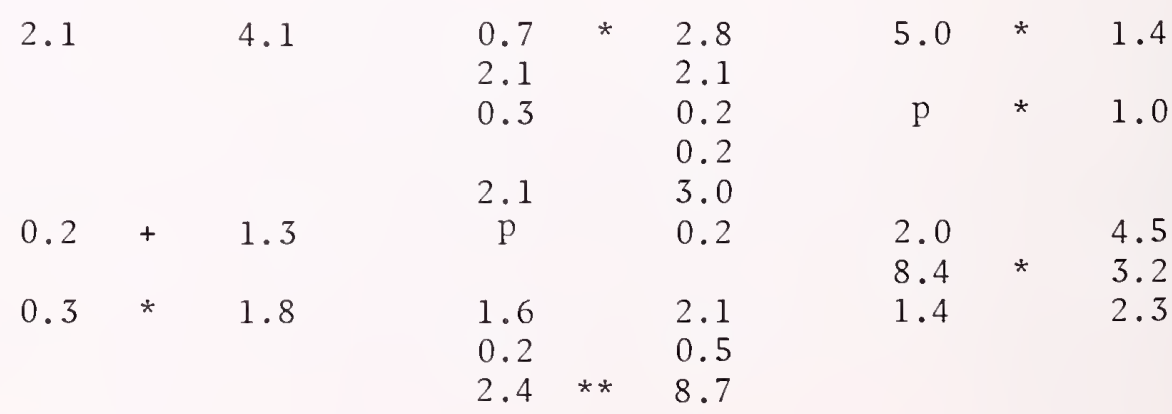

(con.) 
APPENDIX G4 (con.)

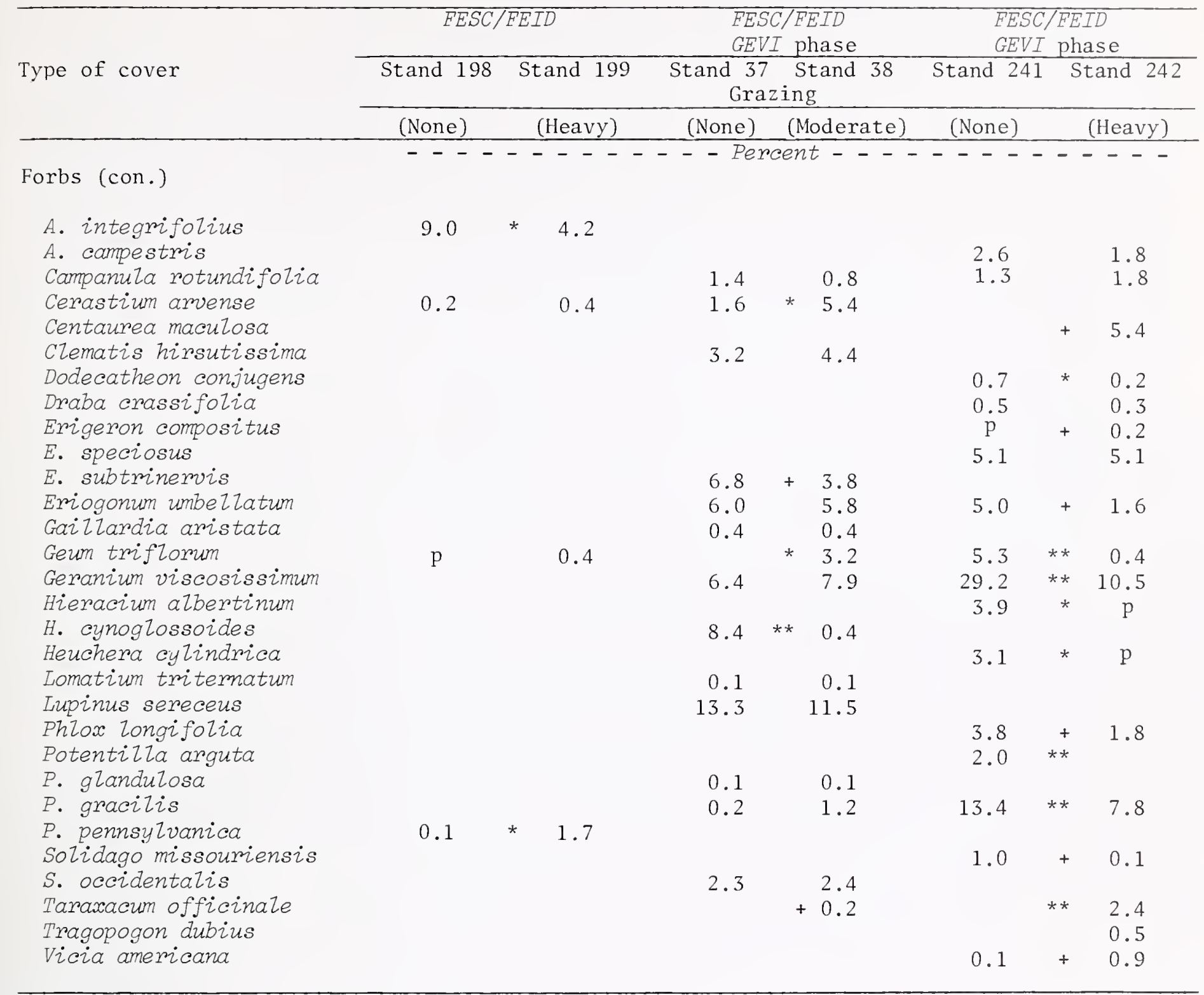

${ }^{1}$ See the narrative in appendix G6 for the location and history of these stands.

${ }^{2}$ Confidence levels $(* *=>99 \% ; *=95-98 \% ;+=90-94 \%$ probability of differing stastistically).

${ }^{3} \mathrm{p}=$ present with less than 0.5 percent canopy cover. 


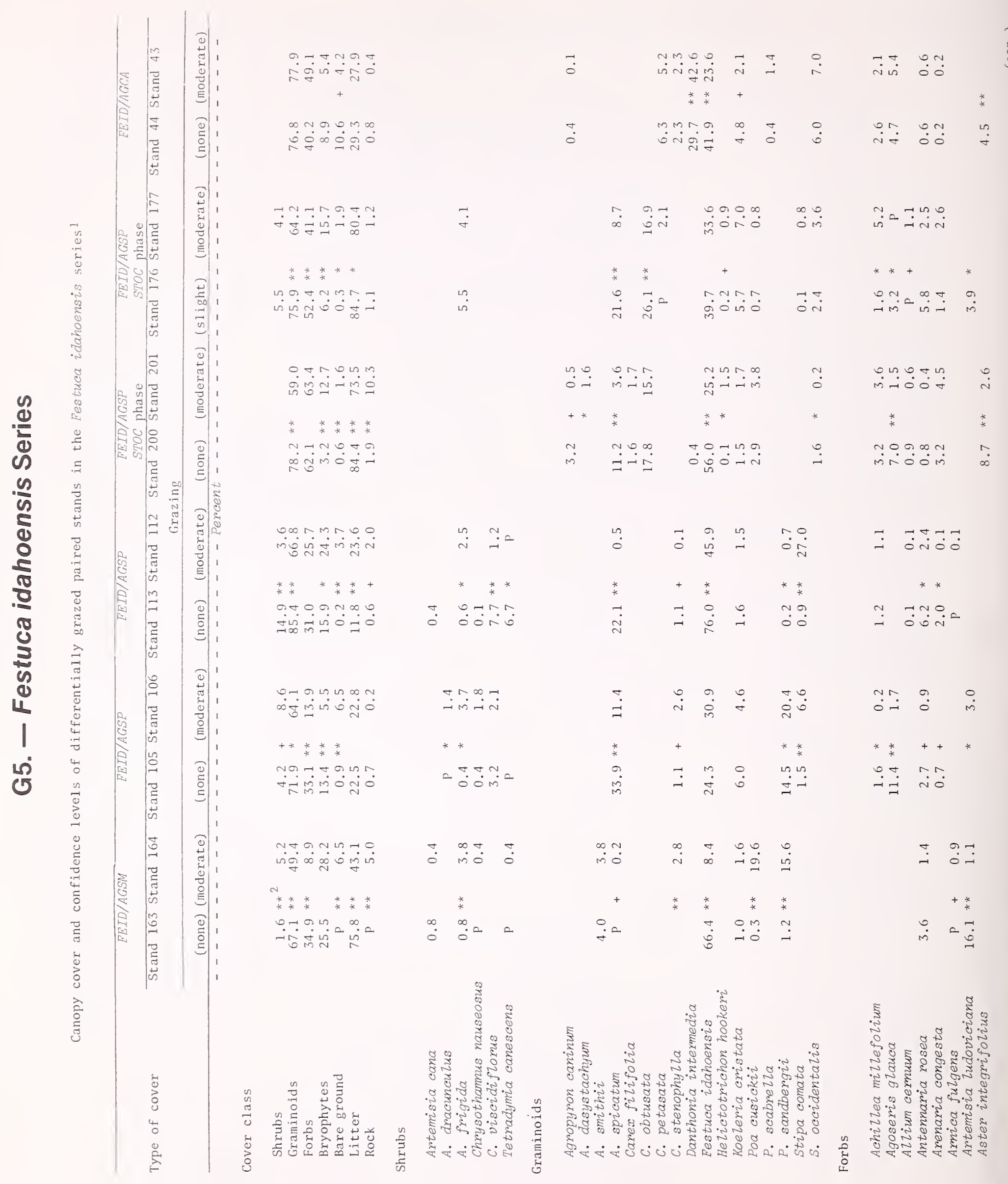




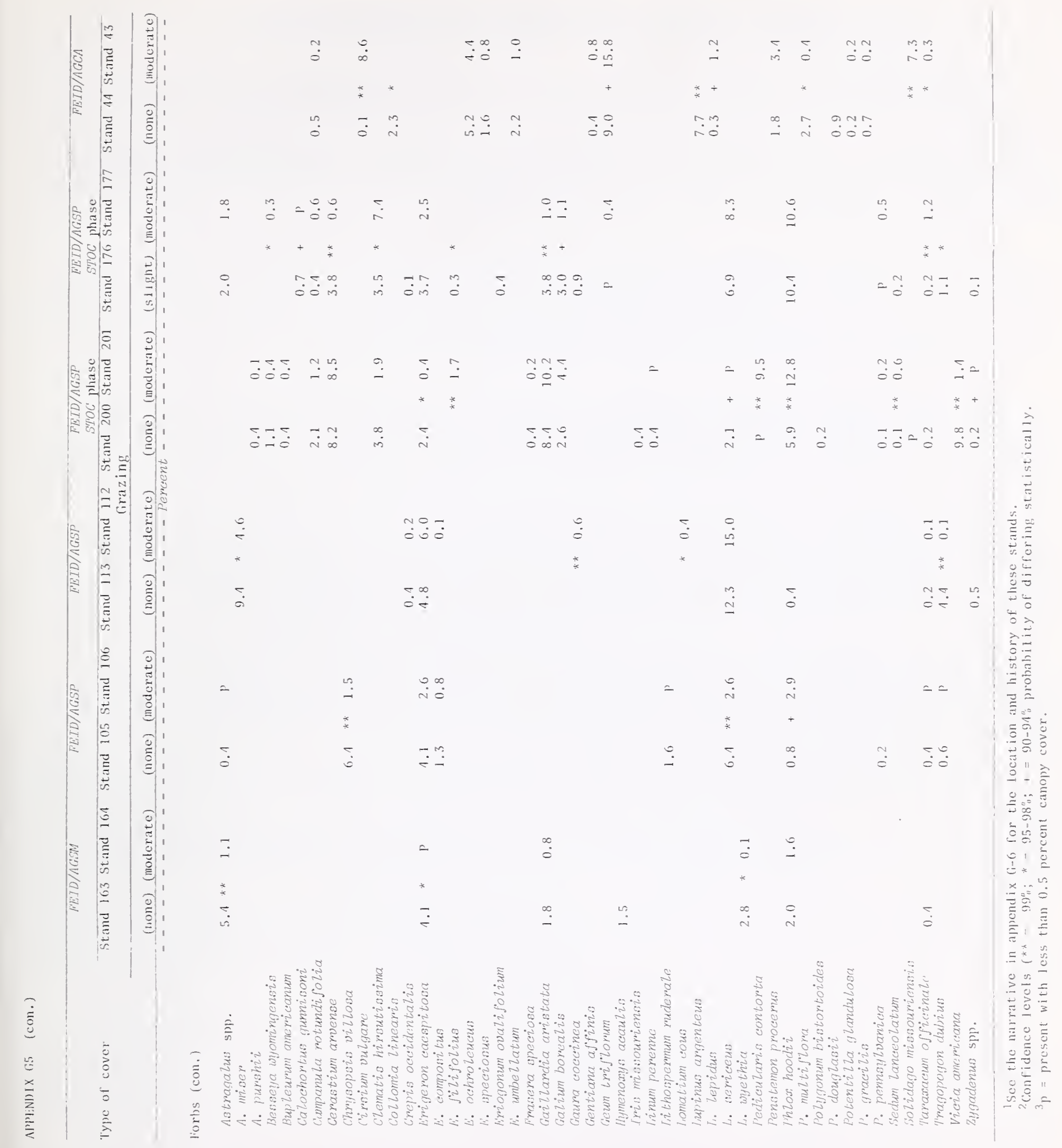




\section{G6. - General Description of Paired Stands}

Stands 102 and 103 - 0ld Whitehall Cemetery, approximately 3 miles (5 km) north of Whitehall, Montana, on a slight westerly exposure at 4,600 ft $(1,400 \mathrm{~m})$ elevation. Stand 102 was within the fenced cemetery and had probably been protected from grazing for at least 30 years; Stand 103 was adjacent to fenced area and apparently received year-round use by horses and cattle. Both stands were probably heavily grazed prior to fencing the cemetery.

Stands 167 and 168 - Near Daisy Dean Creek, 6 miles (10 km) east of Martinsdale, Montana, on a slight southwest exposure at 4,700 ft $(1,430 \mathrm{~m})$ elevation. Both stands have a probable history of heavy sheep grazing, but Stand 167, along a road right-ofway, is now subject to only occasional transient use. Stand 168 is in an adjacent pasture which is being at least moderately grazed by cattle.

Stands 107 and 108 - Near the Quinn Creek Church, 10 miles $(16 \mathrm{~km})$ southeast of Boulder, on a slight northeast exposure at 4,600 ft $(1,400 \mathrm{~m})$ elevation. Stand 107, within the old church driveway, has received negligible use for an undetermined number of years; Stand 108 is currently used by both cattle and horses.

Stands 16 and 17 - The old Rochester Cemetery, 20 miles $(32 \mathrm{~km})$ west of Twin Bridges, on a 10 percent easterly exposure at 5,800 ft $(1,770 \mathrm{~m})$ elevation. Stand 16 is within the cemetery exclosure and probably has not been grazed appreciably for the past 70 years. Stand 17 , just outside of the fence, is currently used by cattle and no doubt was heavily grazed by horses, cattle, and sheep in the past.

Stands 12 and 13 - On Red Bluff Ranch, 2 miles $(3 \mathrm{~km})$ east of Norris, on a 5 percent westerly exposure at 5,000 ft $(1,520 \mathrm{~m})$ elevation. Prior to 1950 , both stands were probably heavily grazed by sheep. Currently, Stand 13 is moderately grazed and Stand 12 heavily grazed by cattle and horses.

Stands 194 and 195 - Oka Coulee Water Catchment Exclosure, 5 miles ( $8 \mathrm{~km})$ northwest of Judith Gap, on a 15 percent west exposure at 5,100 ft $(1,550 \mathrm{~m})$ elevation. Stand 194 is inside the exclosure and has been protected from grazing for about 10 years; Stand 195 is outside the exclosure and is grazed by cattle. Both areas were probably heavily grazed by sheep in the past.

Stands 232 and 233 - Near Bowman's Corner, 20 miles (32 km) southeast of Augusta, on an 8 percent north exposure at an elevation of 4,700 ft $(1,430 \mathrm{~m})$. Stand 232 is along the highway right-of-way with no current livestock grazing. Stand 233 is in an adjacent pasture which receives moderate to heavy cattle use.

Stands 87 and 88 - Along the Mullan Gulch road, approximately 7 miles (11 $\mathrm{km}$ ) northwest of Deerlodge, on a 10 percent southwest exposure at 5,200 ft $(1,580 \mathrm{~m})$ elevation. Stand 87 is along the road right-of-way which receives only transient cattle grazing. Stand 88 is in an adjacent pasture moderately grazed by cattle. Elk and deer use both stands.

Stands 366 and 367 - Near the entrance of the Sun River Game Range, 17 miles (27 km) northwest of Augusta, on a 4 percent north exposure at 4,800 ft $(1,460 \mathrm{~m})$ elevation. Stand 366 has been virtually protected for about 25 years, having received only light horse use. Stand 367 is in an adjacent pasture heavily used by cattle. 
Stands 330 and 331 - On Square Butte, about 7 miles $(11 \mathrm{~km}$ ) southwest of Sun River, on a 3 percent west exposure at 4,300 ft $(1,310 \mathrm{~m})$ elevation. Stand 330 is within an exclosure constructed about 1960; it received only incidental use before then because of lack of water. Stand 331 is just outside of the exclosure and has been grazed by cattle for about 12 years.

Stands 337 and 338 - A fenceline comparison along Willow Creek, 16 miles (26 km) northeast of Sunburst, on a 7 percent southwest exposure at 4,200 ft $(1,280 \mathrm{~m})$ elevation. Stand 337 is on an area slightly grazed by cattle and sheep; Stand 338 is in an adjacent pasture heavily grazed by cattle.

Stands 198 and 199 - The Flagstaff Exclosure, 16 miles (26 km) southeast of White Sulphur Springs, on 3 percent east exposure at an elevation of $5,700 \mathrm{ft}(1,740 \mathrm{~m})$. Stand 198 is inside the exclosure (established 1950) and, except for some elk and deer use, not grazed for 23 years. Stand 199 is immediately outside the exclosure on moderately grazed cattle range.

Stands 37 and 38 - The Eagle Basin Exclosure, about 10 miles (16 km) west of Townsend, on a 25 percent southern exposure at $7,000 \mathrm{ft}(2,130 \mathrm{~m})$ elevation. Stand 37 is inside the exclosure, fenced in 1934. Stand 38 is immediately adjacent to the exclosure on moderately used cattle range.

Stands 241 and 242 - The Gibbons Road Exclosure, 5 miles $(8 \mathrm{~km}$ ) southeast of Sula, on a 33 percent west exposure at $6,000 \mathrm{ft}(1,830 \mathrm{~m})$ elevation. Stand 241 is within the exclosure established in 1958 and thus protected from grazing for 15 years. Stand 242 is next to the exclosure and grazed moderately to heavily by cattle. This area was part of a sheep allotment in the 1930's.

Stands 163 and 164 - The Flat Iron Ridge Exclosure, 3 miles (5 km) southeast of White Sulphur Springs, on a 2 percent north exposure at 5,800 ft $(1,770 \mathrm{~m})$ elevation. Stand 163 is within the exclosure constructed in 1953. The area was probably heavily grazed by sheep in the past, but has received only light deer and trespass cattle grazing for the past 20 years. Stand 164 is next to the exclosure on moderately grazed cattle range.

Stands 105 and 106 - The Hadley Park Exclosure, 9 miles (14 km) south of Boulder,

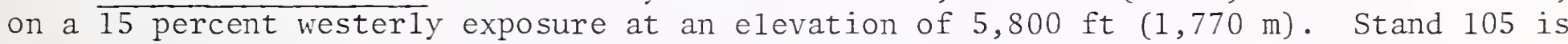
inside of the exclosure and has been protected from grazing by livestock since 1963. Although this area also was probably used fairly heavily by sheep in the past, it is currently used only by elk and deer. Stand 106 is immediately outside of the exclosure on moderately grazed cattle range.

Stands 112 and 113 - The Wall Creek Exclosure, approximately 25 miles (40 km) south of Ennis, on a 12 percent east exposure at an elevation of $6,200 \mathrm{ft}(1,890 \mathrm{~m})$. Stand 113 is inside of an exclosure, built in 1964, that excludes both livestock and big game. Stand 112 is on adjacent range currently used moderately by cattle in the summer and by elk and deer in the winter.

Stands 200 and 201 - The Hatfield Mountain Exclosure, 16 miles (26 km) northwest of the Wilsall, on a 14 percent south exposure at 7,000 ft $(2,130 \mathrm{~m})$ elevation. Stand 200 has been protected from grazing for 11 years. Stand 201 is outside of the exclosure on moderately to heavily used cattle range. 
Stands 176 and 177 - A fenceline contrast near Spotts Gulch, 13 miles (21 km) south of Big Timber, on a 27 percent northwest exposure at 5,700 ft $(1,740 \mathrm{~m})$ elevation. Stand 176 currently receives light cattle grazing, some deer use, and is moderately disturbed by rodents. Stand 177 receives moderate to heavy cattle use and some deer use.

Stands 43 and 44 - The Cliff Lake Natural Area, approximately 40 miles (64 km) south of Ennis, on a 3 percent west exposure at 7,000 ft $(2,160 \mathrm{~m})$ elevation. Stand 44 is within the natural area which was fenced in 1951; this area had been grazed only lightly by sheep before then. Stand 43 is on adjacent range that has been moderately grazed by cattle for the past 21 years, and only lightly grazed by sheep before then. 
Mueggler, W. F. and W. L. Stewart.

1978. Grassland and shrubland habitat types of western Montana. USDA For. Serv. Gen. Tech. Rep. INT-66, 154 p. Intermountain Forest and Range Experiment Station, Ogden, Utah 84401.

A classification system based upon potential natural vegetation is presented for the grasslands and shrublands of the mountainous western third of Montana. The classification was developed by analyzing data from 580 stands. Twenty-nine habitat types in 13 climax series are defined and a diagnostic key provided for field identification. Environment, vegetative composition, forage production, changes with grazing, and range management practices are described for each habitat type.

KEYWORDS: vegetation classification; habitat types; range types; mountain grasslands; Montana; range ecology; range management.

Mueggler, W. F. and W. L. Stewart.

1978. Grassland and shrubland habitat types of western Montana. USDA For. Serv. Gen. Tech. Rep. INT-66, 154 p. Intermountain Forest and Range Experiment Station, Ogden, Utah 84401.

A classification system based upon potential natural vegetation is presented for the grasslands and shrublands of the mountainous western third of Montana. The classification was developed by analyzing data from 580 stands. Twenty-nine habitat types in 13 climax series are defined and a diagnostic key provided for field identification. Environment, vegetative composition, forage production, changes with grazing, and range management practices are described for each habitat type.

KEYWORDS: vegetation classification; habitat types; range types; mountain grasslands; Montana; range ecology; range management. 


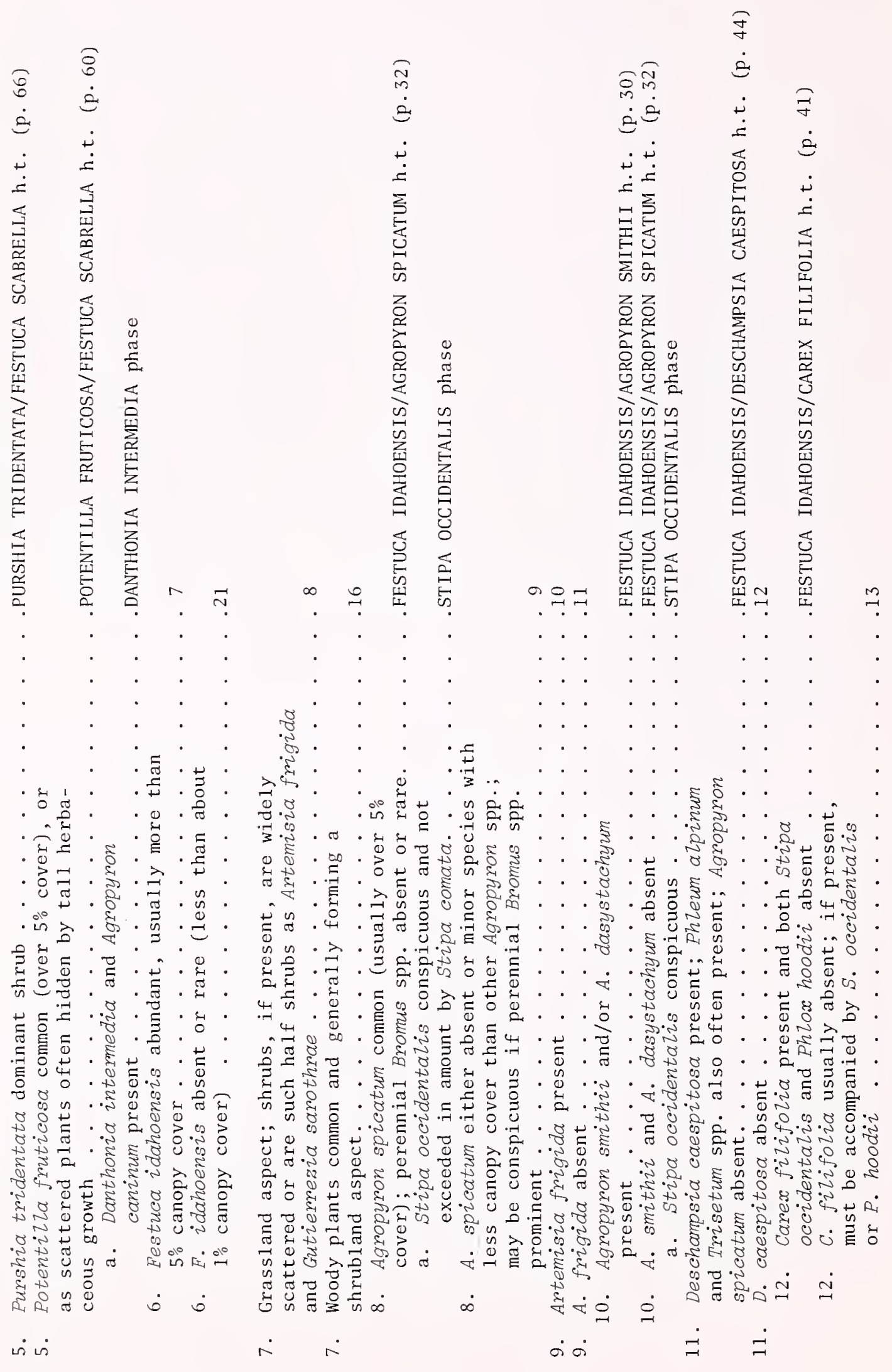


30. Sipa corate or Doutelous grasitis dominan grasses (usual1y east of Cont inental Divide on dry alluvial beneles and valley floors

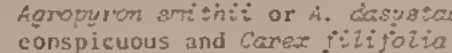

usually presene.

30. 3. comato and 8 , omacilis absent: Descreapsis asespitosa and Carex spp. dominant graminoid (high elevation valley bottoms and flood

TIPA COMTA/BOUTELOUA GRACILIS h. T. (p. 10)

ACROPYRON SNITHII phase

therin a conspicuous associate. DESCHAMPSTA CAESPITOSA/CAREX Spp. h.t. (p. 45) SARCOBATUS VERMICULATUS/ELYMUS CINEREUS h.t. (1). 74) the herbaceous vegetation.

\section{GRASSLAND AND SHRUBLAND HABITAT TYPES OF WESTERN MONTANA}

W.F. Mueggler

W.L. Stewart

\section{Published as part of USDA Forest Service} General Technical Report INT.66

\section{KEY TO MAJOR GRASSLAND AND SHRUBLAND HABITAT TYPES} IN WESTERN MONTANA.

(Instructions: This key splies specifieally to nonforest vegetation not severely altered from pristint eonditious-the user must :1llon for changes in comnunity composition caused by abusive of relatively undiscurbed conditions oceurring on similar soils and landforms should be observed. Unavoidably, relative amoums of species are sometimes used as separation criteria. In most instances of qulestionable separation, the key will lead eventually to the same habitat type. Occnsionally n comnanty will be identified correctly even though one of the species constituting the litbit:at type or phase name is absent. This can happen because habitat types. the cntite thoral conposition and abt just ly key" is worhable with a taxonomic knowledge of only 10 slurabs, 18 graminoids, and 6 forbs, most of which are common speeies readily identified by range technieians.)

Festue scabrolta

cover exceeding section

Grassland aspect; shrubs, if present, are iridely

scattered or are such half-shrubs as Antemigio

froigida and Gution

jruticosa present. go to 5)

hoody plants conthe generaily

thland aspect.

Agrropynon spicatum connon (at least $1 \mathrm{plant} / 4 \mathrm{ft}^{2}$ )

Agropida ind G. sarothrue usually conspicuous:

Gormitur viscosiseirion and Donthonic intermedia

a. Stipa comata, s. partra, or Boteloura

A. spicatium if present. usually not common and

not atcompanied by vither A. Juigida or G. Bamothwa

G. viscosissimu tnd/or D. intertadic ofteu present

and conspicuous

a. Stipa ricinarisonit present

iscosistion

Shrubby aspect cirated by Artemisia tridentata

Shrubby aspect caused by species other than

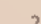

FESTUCA SCABRELLA/AGROPYRON SPICATUM h.t. (p. 23) STIPA COMATA phase

FESTUCA SCABRELLA/FESTUCA IDAHOENSIS h.t. (p. 27) STIIA RICHARDSON1 1 pha

GERINIUY YISCOSISSIMYM Phase

ARTEMISA TRIDENTATA/FESTUCA SCABRELLA h.t. (p. 5t) 
5. Furshia tridentata doninant shrub

PUPSHIH TRIOENTATA/EESTUCA SCABRELLA h.t. (p. 60 )

Potentiziza jruticaea comon (over ss cover). or scattered plants often hidden by call herber

POTESTILLA FRITICOSA FESTUCA SCABRELLA h.t. (p. 60) a. Danthoria intemedic and Agropyno OATTHONIA INTERMEDIA phase

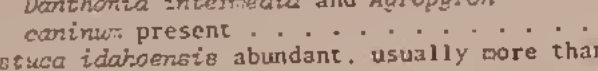

6. Festuca idaboensis abundant, usually pore tha

G. F. idahoensis absent or rare (iess than about

Grassland aspeet; shrubs. if present, are widely scattered or are such half shrubs as Artemisia frigid

and Gutierrezia sarothrae. . . Fily forming a

Woody plants comnon and generaily for.
shrubland aspect. cover): регелnial Bromus spp. absent or rare. a. Stipa occidentalis conspicuous and not exceeded in anount by Stipa conata. . . .

8. A. spicatum either absent or minor species w less canopy cover clins other

prominent $\ldots \ldots \ldots \ldots$

9. Artemisia frigida present . . . . . . . . . . . . . 11

A. frigida absent
10. Agrapyron smithit and/or A. dasyetachyido

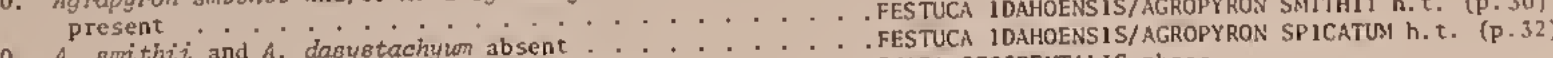

10. A. Emithii and A. dasystachyin absent

a. Stipa occidentalis conspicuous a pinim

11. Deschampia caespitosa present; Phiewn alpinum
and Trisetwn spp. also often present; Agropyron

. . . FESTUCA IDAHOENSIS/DESChAMPSIA CAESPITOSA h.t. (p. 44 )

12. Carex filifolia present and both stipa

12. C. filifolis usually hoodit absent

C. Thtifolia usually absent: if present,

must be accompanied by $S$. occidentalig . . . . . . .13

FESTUCA IDAHOENSIS/AGROPYRON SPICATUM h.t. (p.32) STIPA OCCIDENTALIS phase

IDAHOENSIS/DESCHAMPSIA CAESPITOSA h.t. (p. 44)

13. Stipa richardeonit abundant, usually exceeding

13. $20 \%$ canopy cover michordsonit usualiy absent, but if present

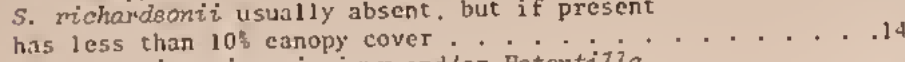

I4. Geraniwn viscosi6simon and/or Potentilia . . . . gracizis present.

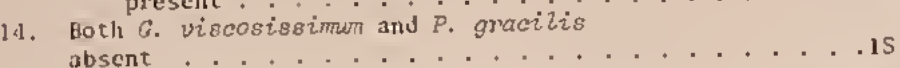

15. Agropyron smithii and/or $A$. dasystachylom present . . . . . . FESTUCA IDAHOENSIS/AGROPYRON SM1THI1 h.t. (p. 30)

. . . FESTUCA 1OOHONSISAGGROPYRON SPICATUM h.t. (p. 32)

STIPA OCCIDENTALIS phase

16. Shrubby aspect created by species of $\ldots \ldots$. I7

16. Shrubby aspect created by shrubs other than

Artemisia, which may be understory to

taller shrubs.

17. Artemisia arbuscula at least $5 \%$ canopy cover, ven though Artemisia tridentata may be sen that hore bundant

7. A. Qrbuscuza absent or rare. . . . the

Artemisia tmipartita present and the ". ". dominant shrub; Artemisia tridentata may also 18. Artemisia tridentata the dominant shrub.

. Geraniwn viscosissimum, Potentizza gracilis, or Potentill a glandulasa and present

9. Purshia tridentata abundant, usualiy dominant. . ARTBMISIA TRIDENTATA/FESTUCA IOAHOENSIS H.t. (p.sS) Terawium Viscosissimum phase

Rhus trizobata conson.

scattered patcles on well-drained uplands or hillsides.

.20 RHUS TRILOBATA/FESTUCA IDANOENSIS h.t. (p. 72)

21. Agropyron spicatum usually abundant; may have less than 108 canopy cover if Boutelona gracizi has less than about $20 \%$ cover: woody plants may or may not be abundant. at ieast iess than about A. spication absent, or at lenst less than about
28 canopy cover: woody plants other than halfshrubs rare G. Grassland shrubs, if present, are widely seattered or are such half-shrubs is

2.remisia frigida and Gutierrezia sarothrae. . . . . .23

22. hoody plants common and generally forming a

23. Boutelona gracilis usually more than So c:nopy cover; primarily' east of Continental Divide
a. Either Liatris plonetata or Carex

23. B. filifolia present.

34. Rhizomatous wheat grasses and usually care Rhi zomatous wheatgrasses and usuily of Continental Divide. . . . . a. Stipa viridula and often Vicia

24.erticana present. Rhizomatous wheatgrasses absent: Poa gardberg
24. usually but not always present

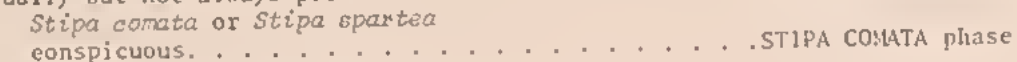

25. Shrubby aspect ereated by species of Artemisia. . . . . . 26
25. Shrubby aspect ereated by shrubs other than

tha arbuseuza at least 5 canopy cover. Stipa comata present: A. tmidentata absent. . . . . . . . . 26. A. arbuscula absent or rare: A. tridentata

.AGROPYRON SPICATUA/BOUTELOUA GRACILIS I. T. (p. I.t) LIATRIS PUNCTATA phase

AGROPYRON SPICATUM/AGROPYRON SMITHII h.t. (p.18 STIPA VIRIOULA phase

AGROPYRON SPICATUSS/POA SANDBERGII h.t. (p. 21 )

26

ARTEMISIA arbuscula/agROPYRON SPICATUsi h.t. (p. 47) STIPA COMATA phasc

ARTEMISIA TRIDENTATA/AGROPYRON SPICATUM h.t. (p. 50) PURSHIA TRIDENTATA/AGROPYRON SPICATUM h.t. (p. 64)

37. Piuchic tricientata conspicuous, usually dominant. 
GRASSLAND AND SHRUBLAND HABITAT TYPES OF WESTERN MONTANA W.F. Mueggler
W.L. Silewar

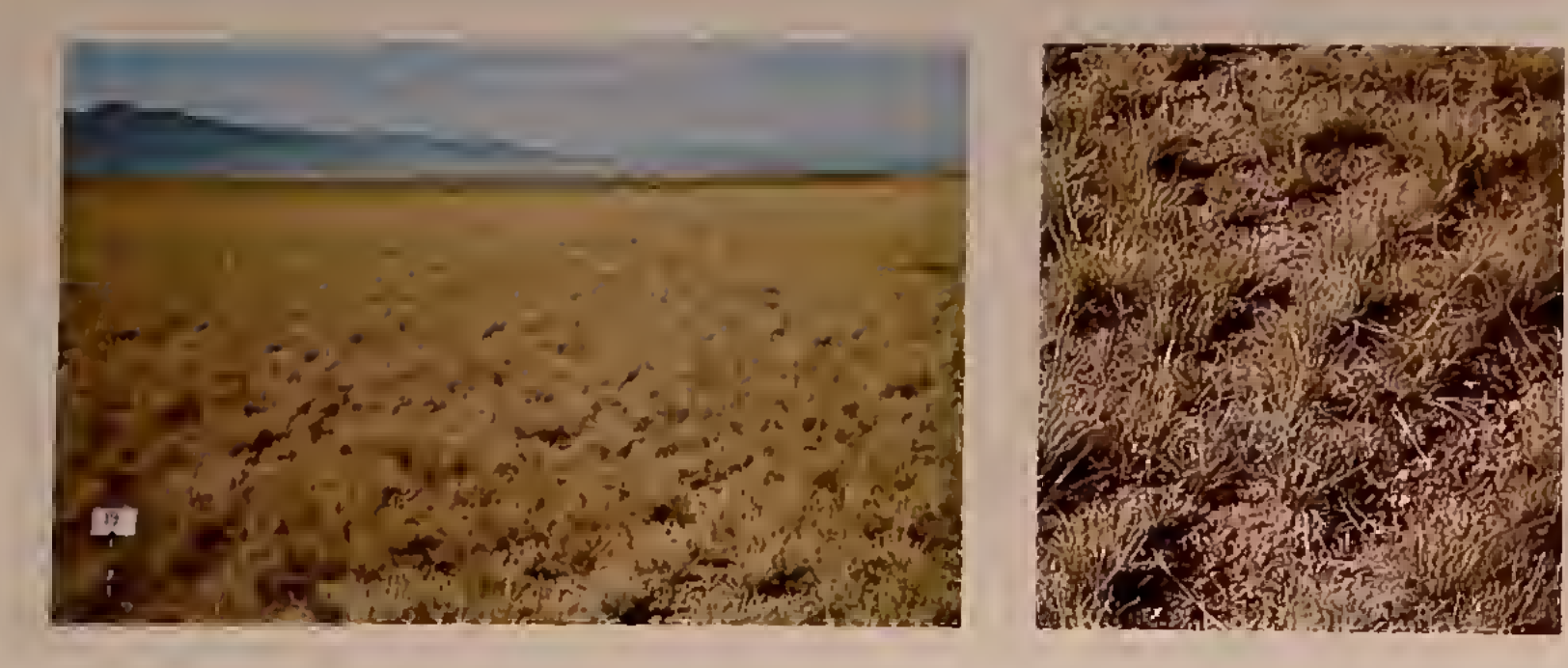

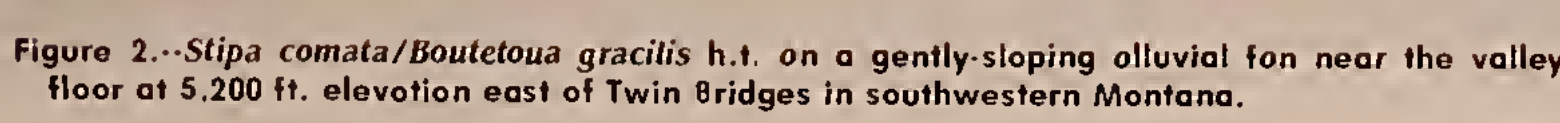

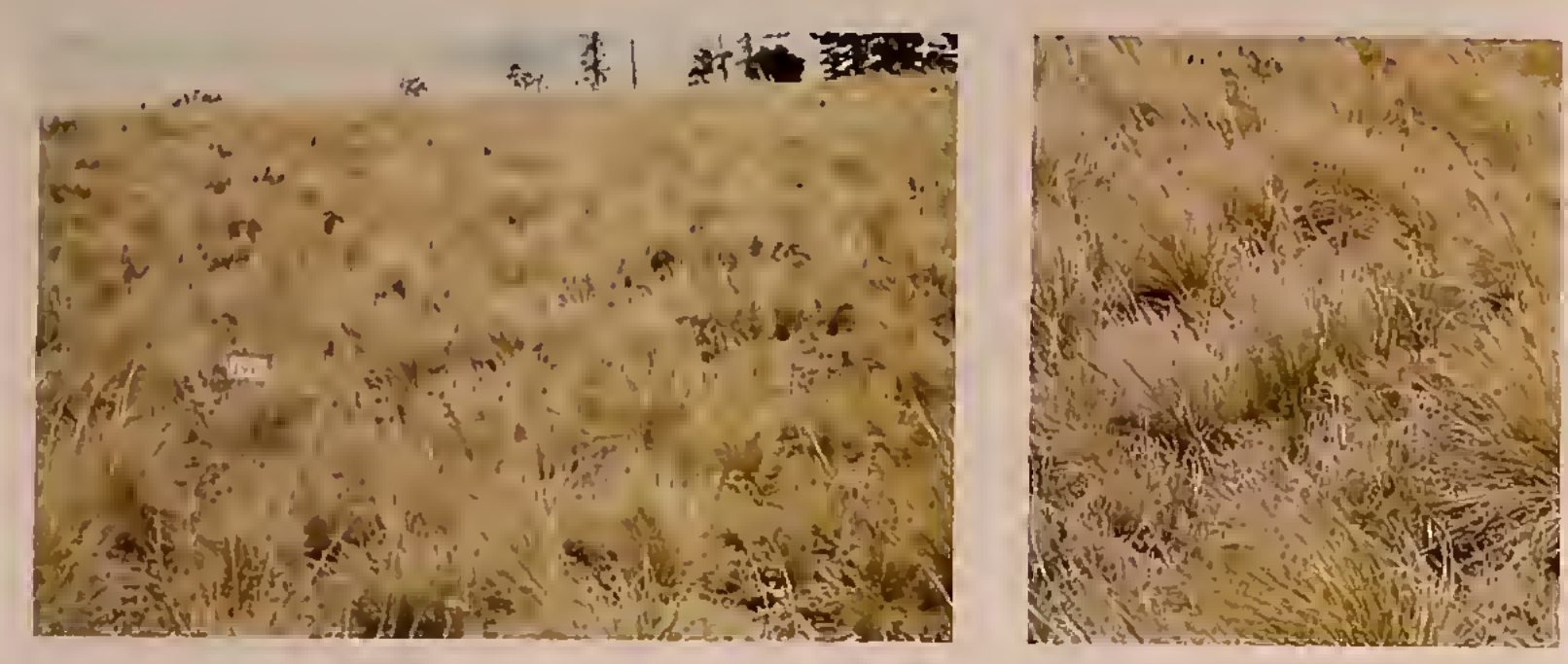

Figure 6... Festuca scabretta/ Agroppyron spicatum h.t. on a southwest.focing slope, $3,500 \mathrm{fth}$

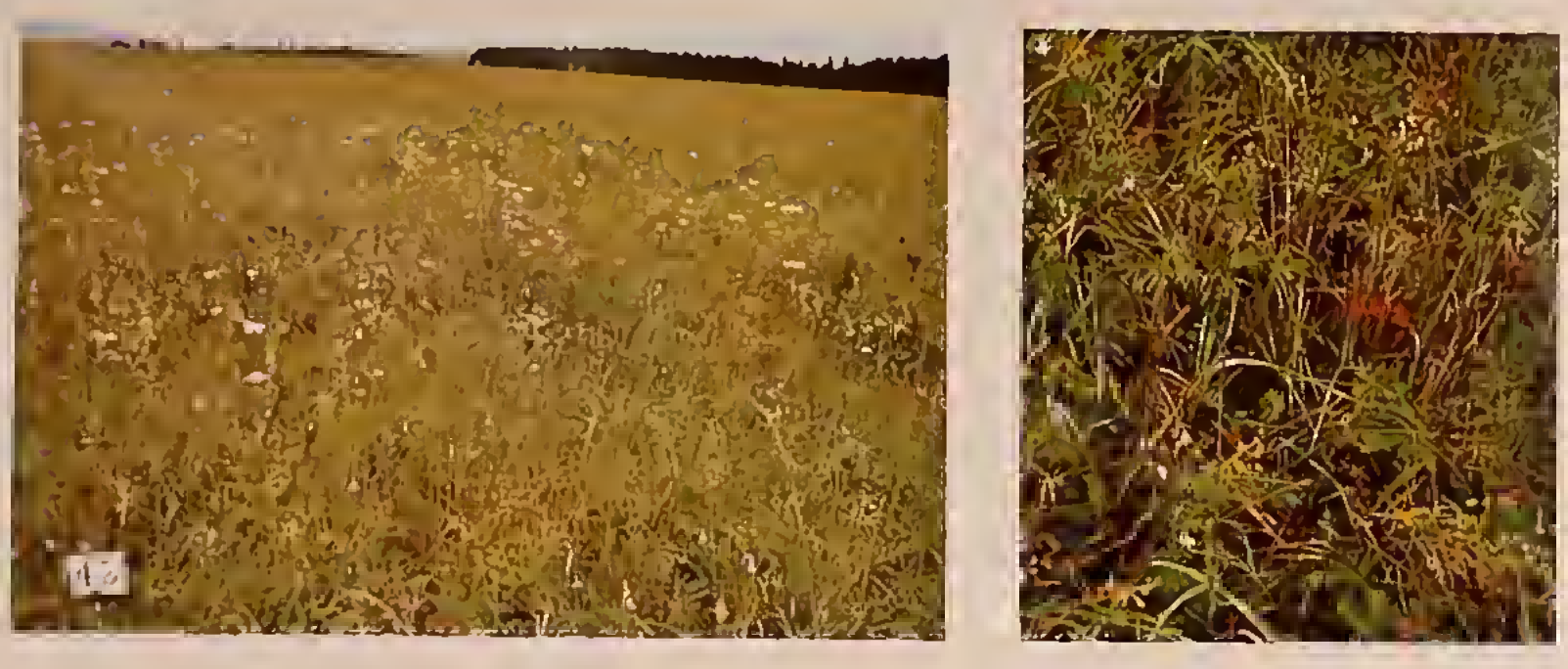

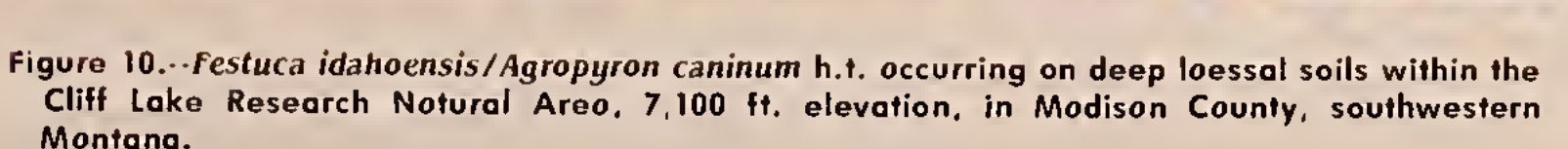

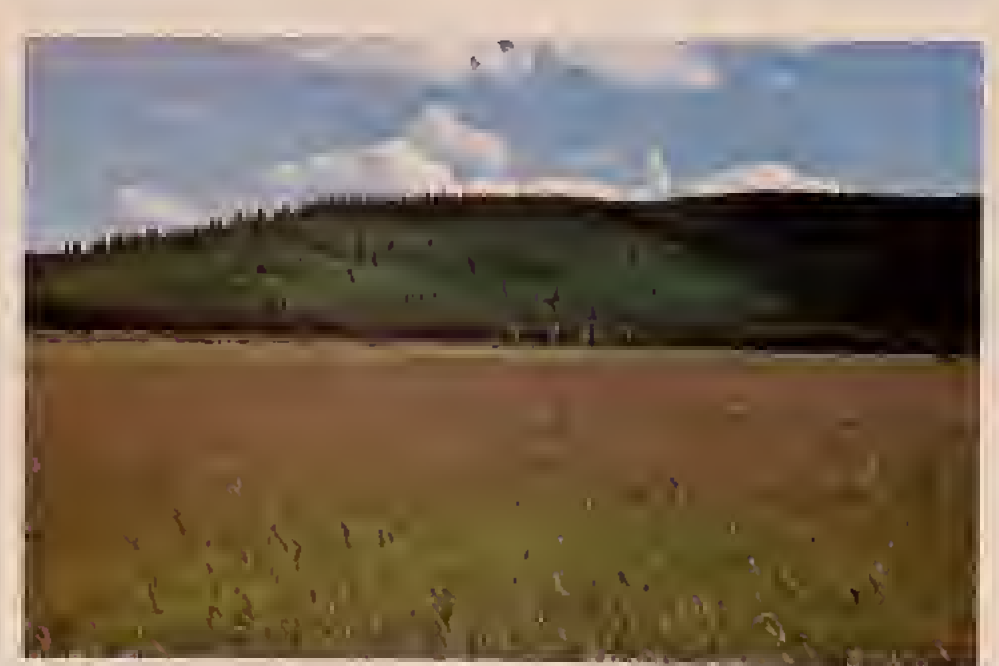

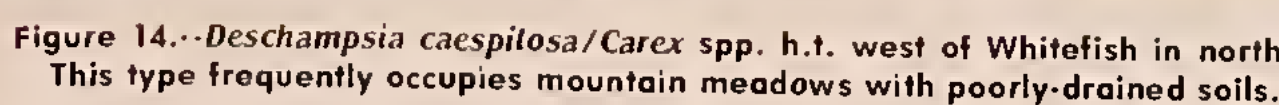

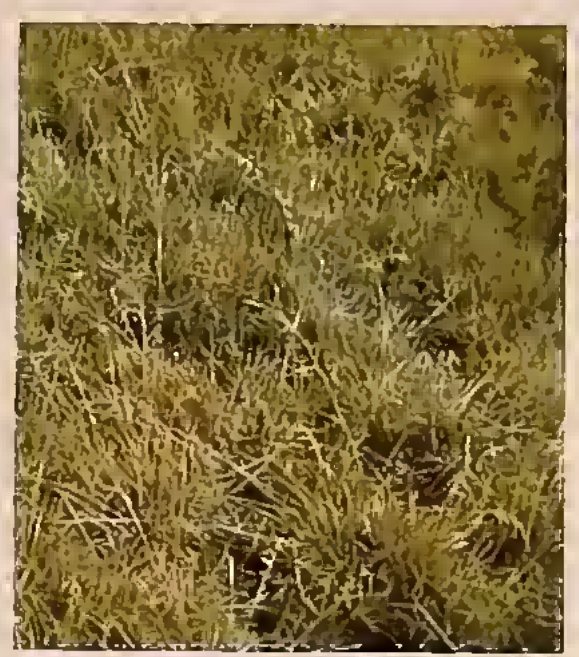

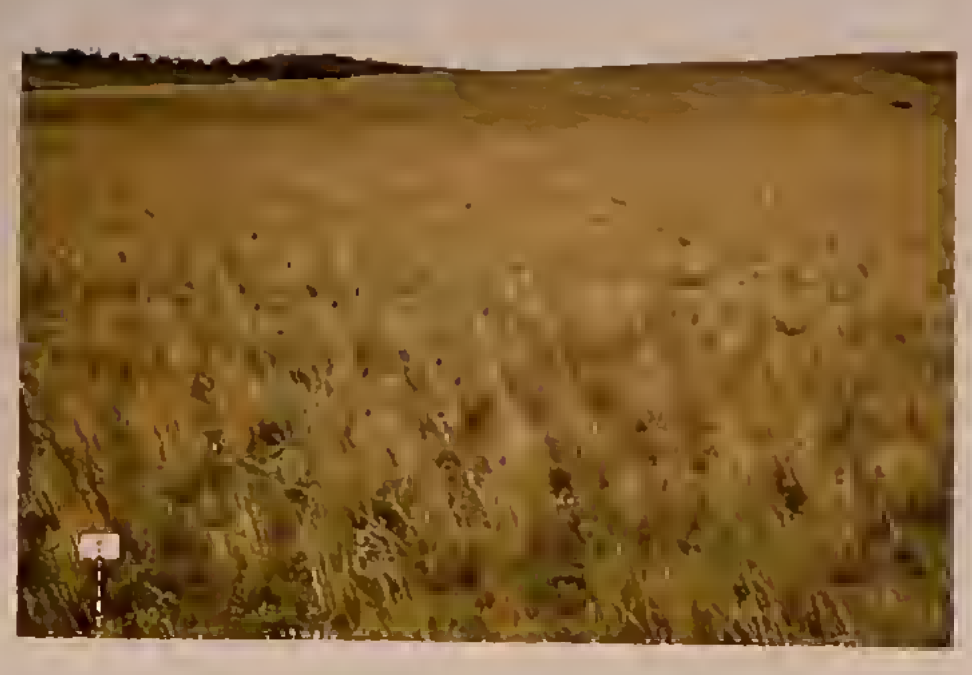

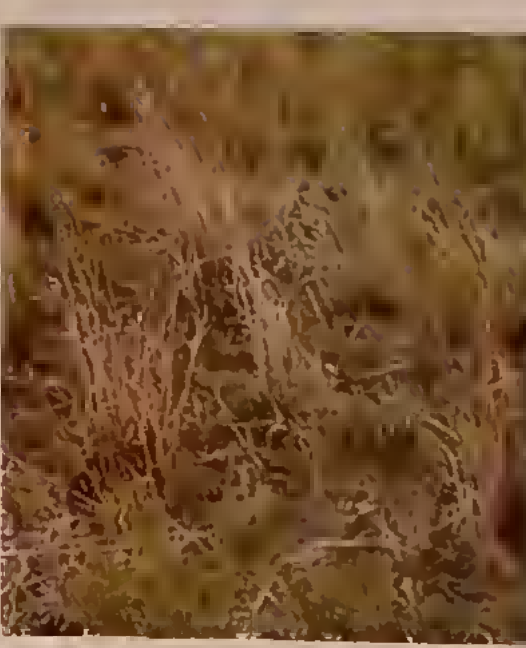

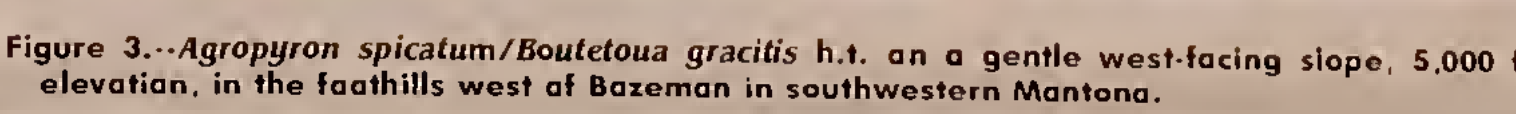

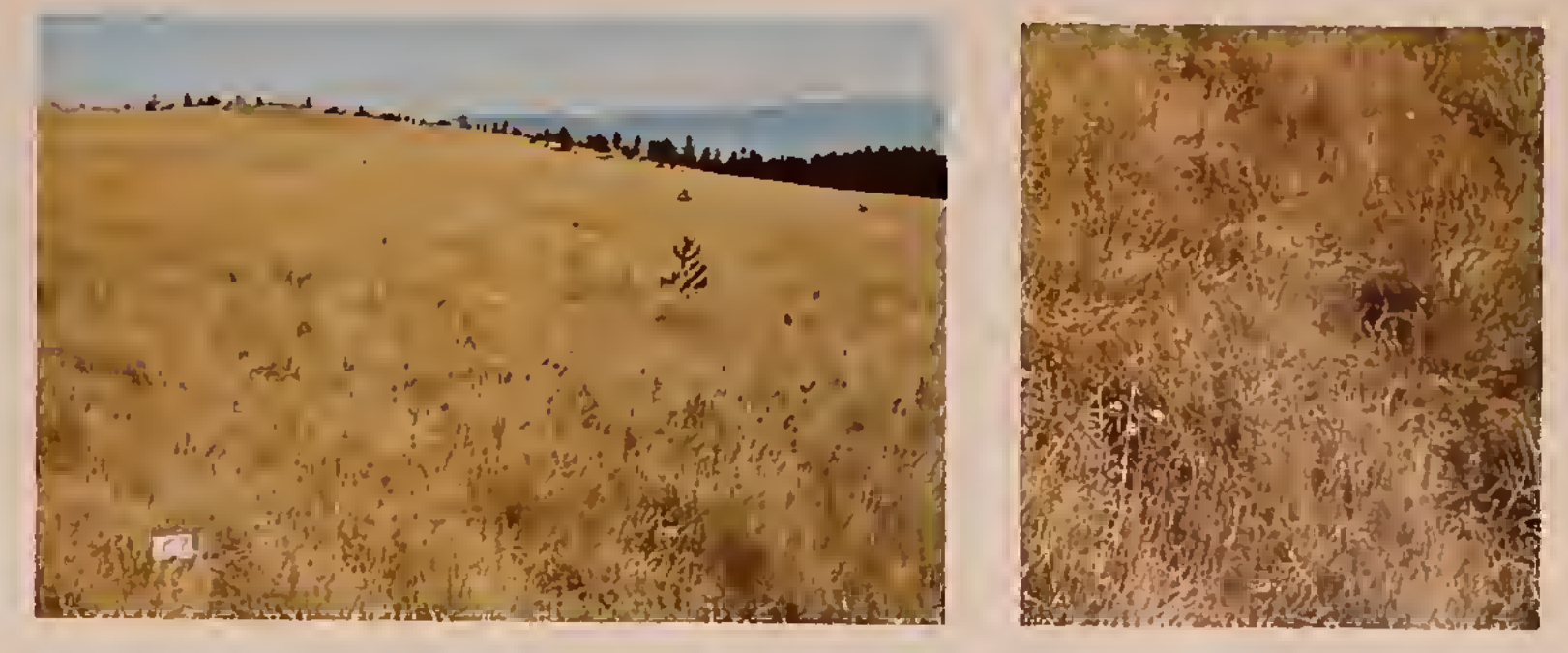

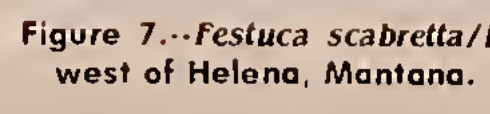
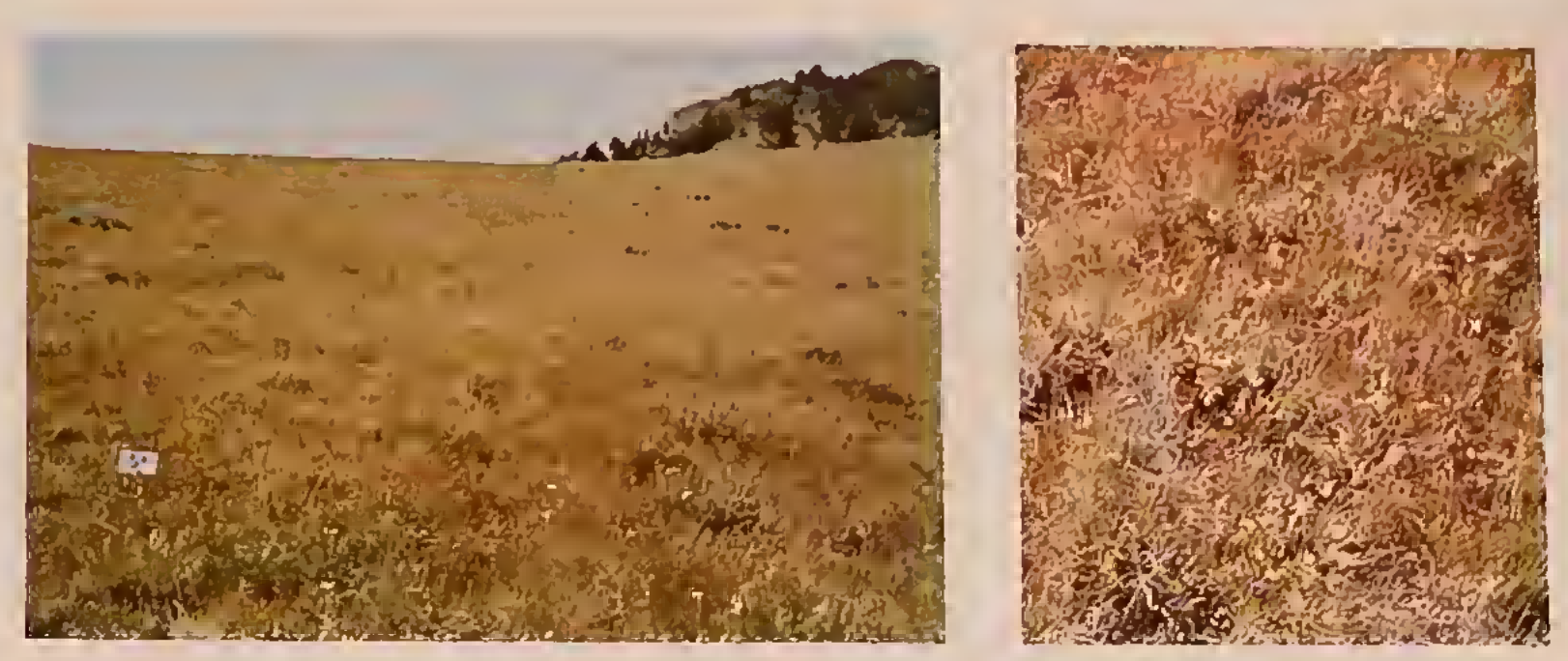

Figure 11. ... Festuca idahoensis/ Carex fitifolia
neor Whitehall in southwe stern Montana.
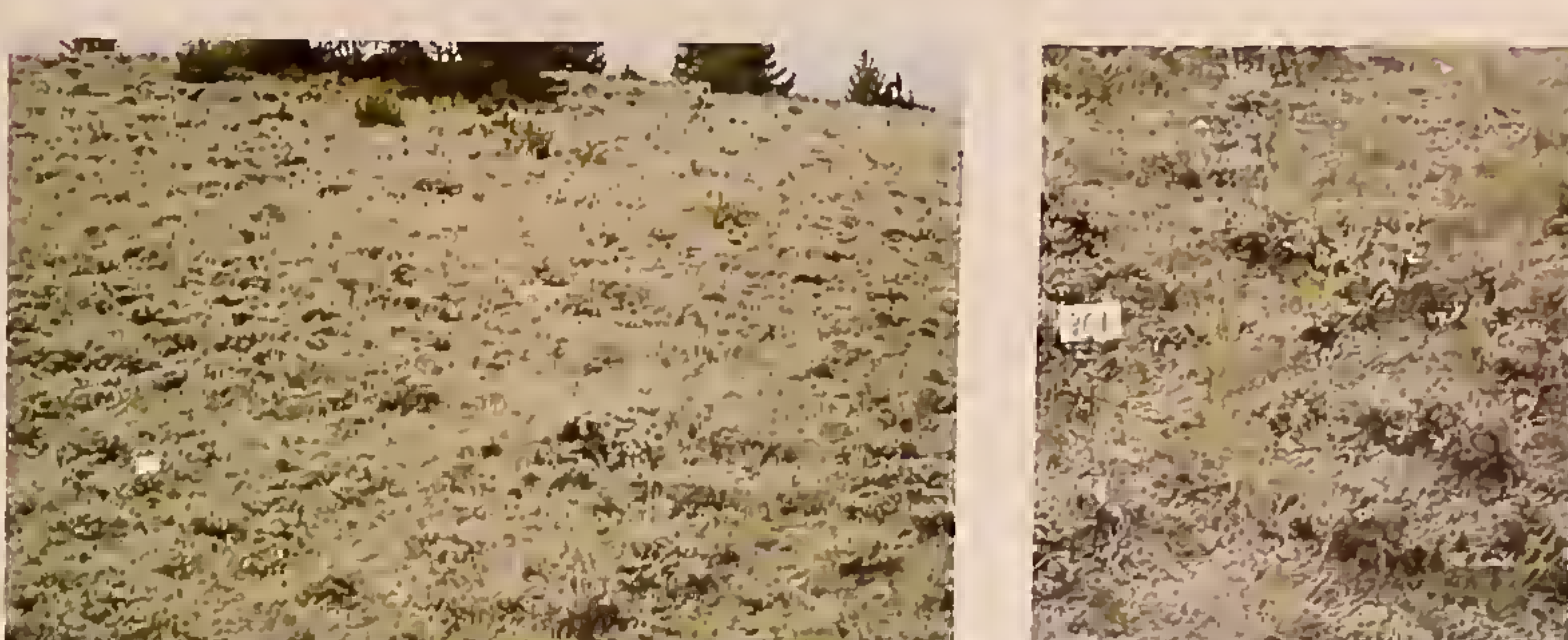

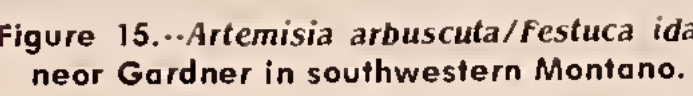
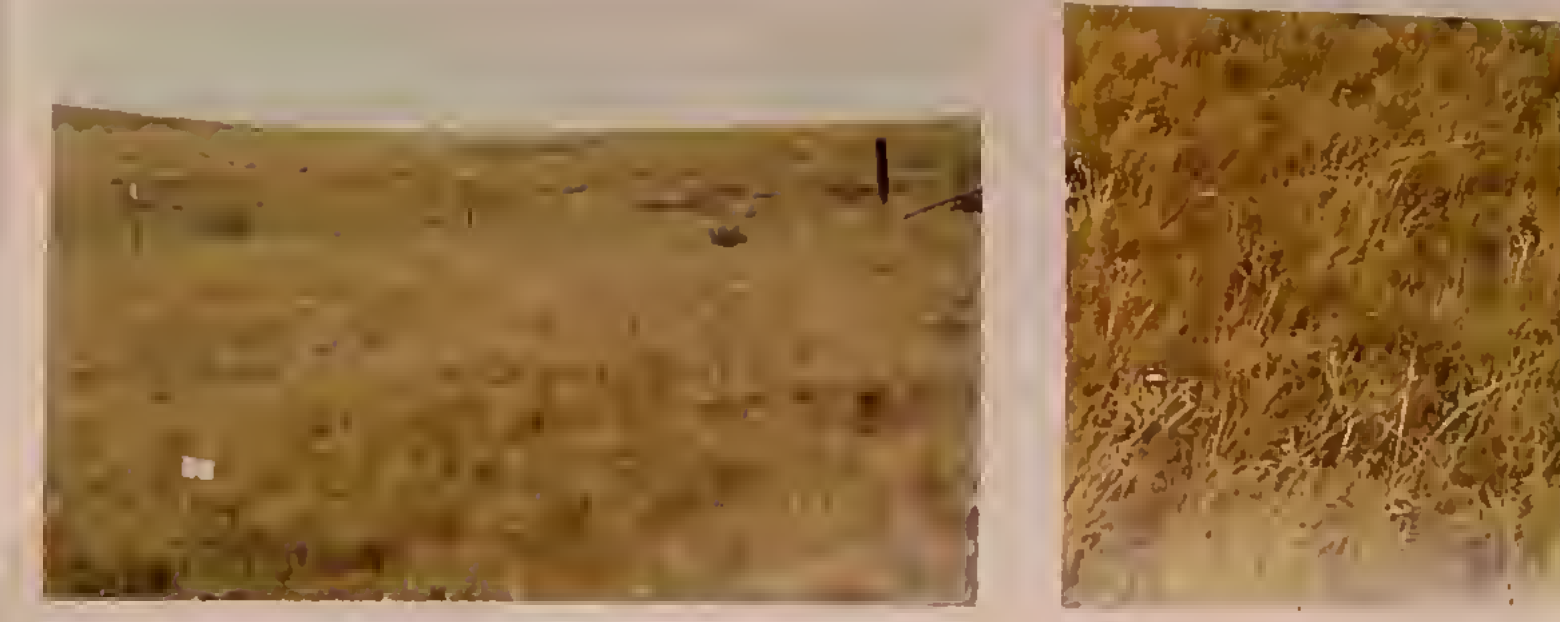

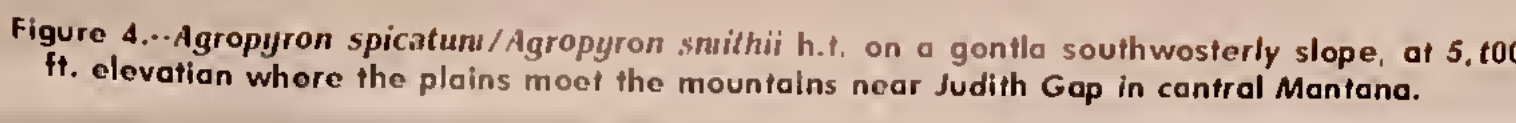

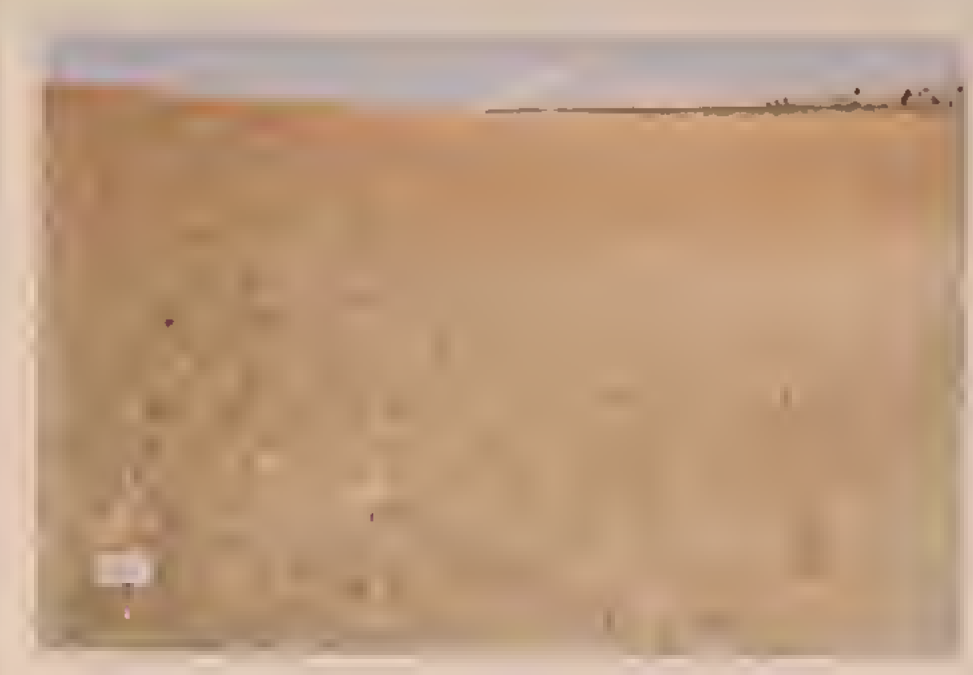

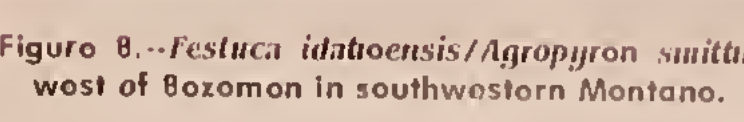

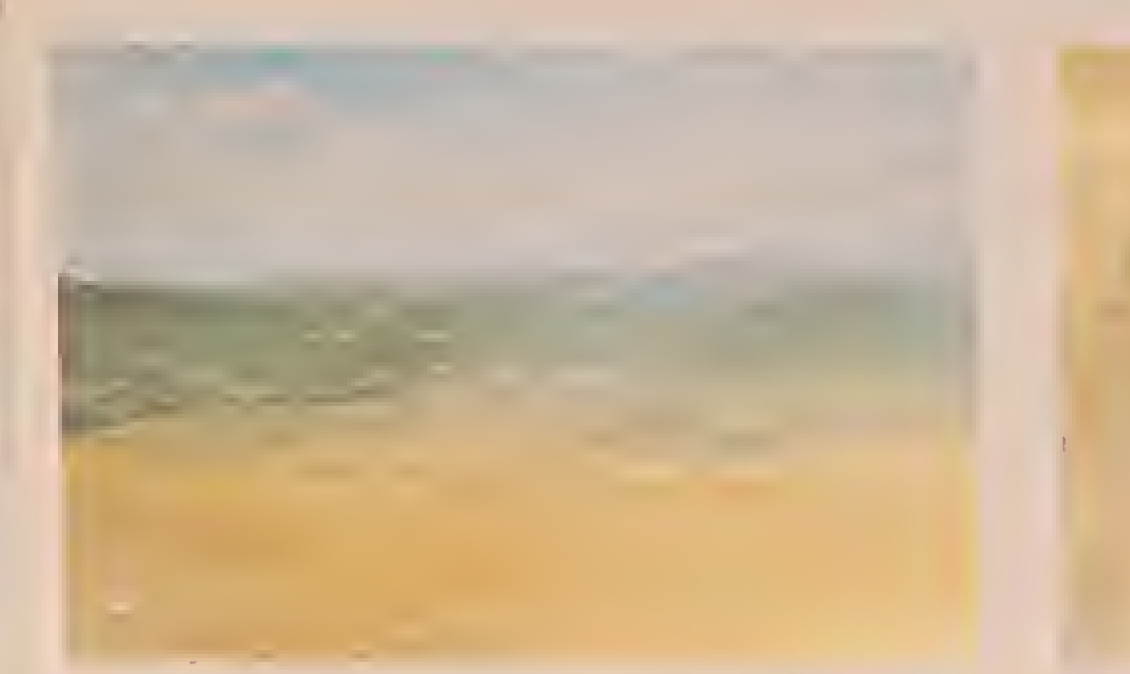

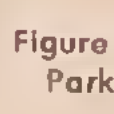

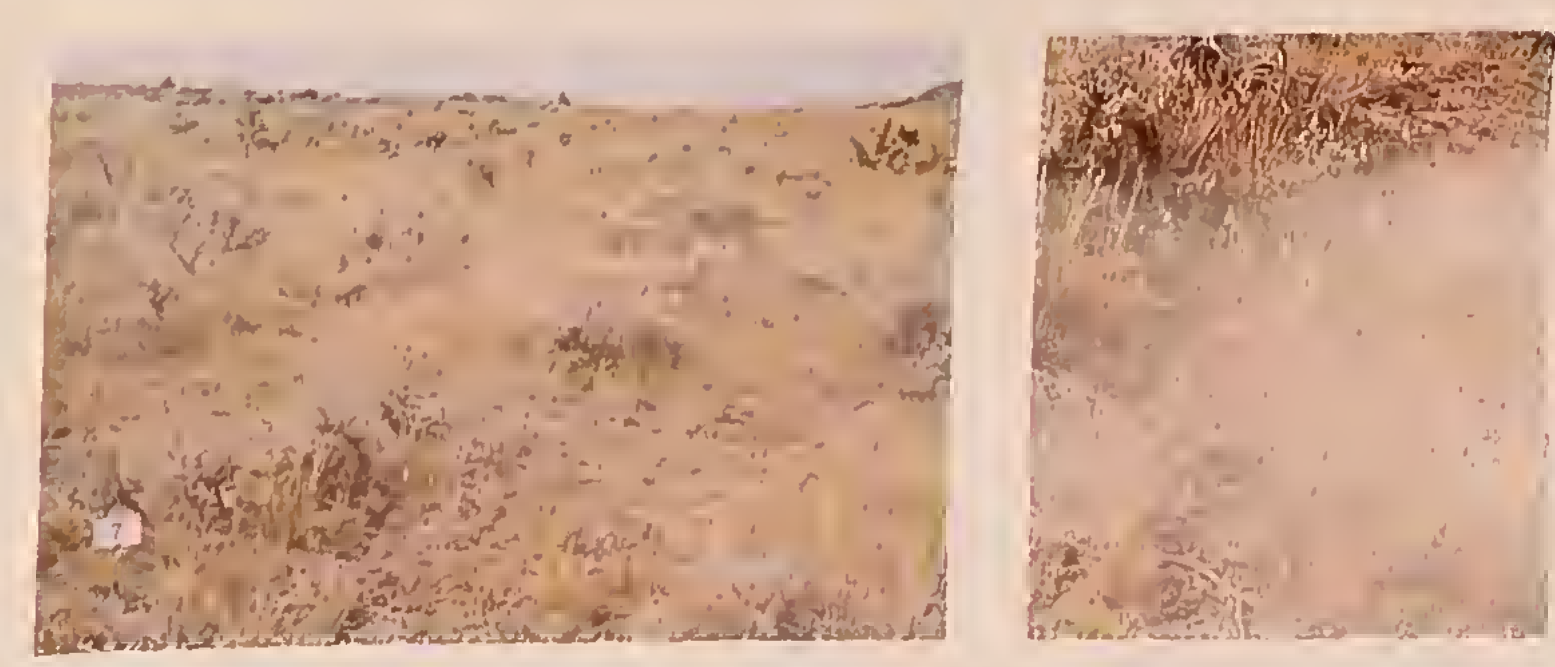

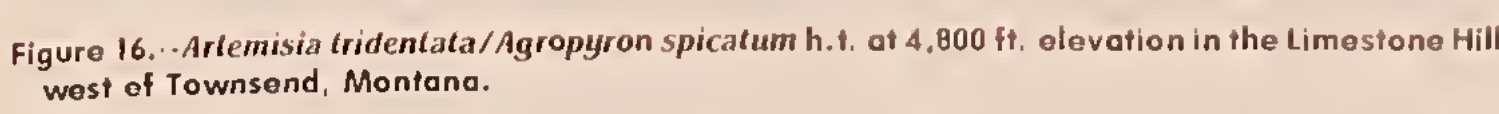


The Intermountain Station, headquartered in Ogden, Utah, is one of eight regional experiment stations charged with providing scientific knowledge to help resource managers meet human needs and protect forest and range ecosystems

The Intermountain Station includes the Stales of Montana, Idaho, Utah, Nevada, and western Woming. About 250 million acres, or 90 percent, of the land area in the Station territory are classified as forest and rangeland. Theśe lảnds include grasslands, deserts, shrublands, alpine areas, and well-stocked forests. They supply fiber for for est industries; minerals for energy and industrial development; and water for domestic and industrial consumption. They also piovide recreation opportunities for millions of visitors each year.

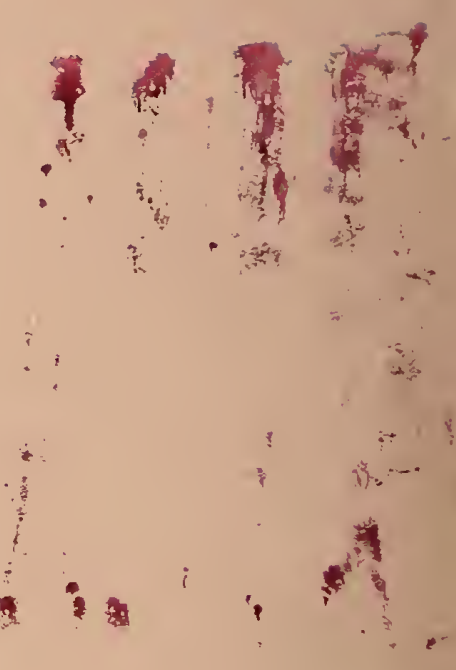

Field programs and research work units of the Station are maintained in:

Boise, Idaho

Bozeman, Montana (in cooperation with Montana State University)

Logan, Utah (in cooperation with Utah State University)

Missoula, Montana (in cooperation with the University of Montana)

Moscow, Idaho (in cooperation with the University of Idaho)

Provo, Utah (in cooperation with Brigham Young University

Reno, Nevada (in cooperation with the University of Nevada)

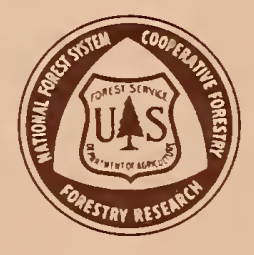

